\title{
PERILAKU MENYONTEK: PERSEPSI TERHADAP IKLIM SEKOLAH DENGAN KETIDAKJUJURAN AKADEMIK
}

\author{
Yuli Fitria \\ Sekolah Tinggi Ilmu Kesehatan Banyuwangi \\ fitriayuli818@gmail.com
}

\begin{abstract}
Abstrak. Perilaku ketidakjujuran akademik bertentangan dengan norma, nilai pendidikan karakter serta agama. Salah satu bentuk perilaku ketidakjujuran akademik yaitu menyontek. Ironisnya pelaku penyontek tidak menyadari perilakunya sebagai kesalahan. Iklim sekolah yang kurang kondusif cenderung dipersepsikan secara negatif, diduga menjadi penyebab siswa leluasa melakukan ketidakjujuran akademik, sehingga perlu dilakukan upaya pencegahanya. Hipotesis, ada hubungan negatif significan persepsi positif terhadap iklim sekolah dengan perilaku ketidakjujuran akademik. Subjek penelitian siswa kelas XII SMAN Darul Sholah Banyuwangi sejumlah 120 siswa. Teknik sampling purposive sampling. Alat ukur menggunakan Perception School Climate Scale dan Academic Dishonesty Scale. Analisis data korelasi product moment. Hasil menunjukan bahwa terdapat hubungan negatif yang signifikan $(\mathrm{r}=-0,129, p=0,015)$. Artinya, semakin positif persepsi terhadap iklim sekolah maka semakin kecil kecenderungan perilaku ketidakjujuran akademik dan sebaliknya. Pentingnya menciptakan iklim sekolah yang dipersepsikan secara positif dapat digunakan sebagai upaya mencegah terjadinya ketidakjujuran akademik seperti menyontek.
\end{abstract}

Kata kunci : persepsi; iklim sekolah; ketidakjujuran akademik

\begin{abstract}
Dishonest behavior is very contrary to the norm and religion values. One of academic dishonest behavior is cheating. Unfortunately the cheaters do not realize their behavior as an error. A less conducive school climate tends to be perceived negatively and it is suspected to be the reason students are free to cheat when doing academic dishonesty, so necessary to prevent it. The subject is the XII Grade students of Darus Sholah Banyuwangi Senior High school as much 120 students. The sampling technique uses purposive sampling. Instruments used are Perception School Climate Scale and Academic Dishonesty Scale. Data analysis uses product moment correlation. Results is a significant negative $(\mathrm{r}=-0,129, p=0,015)$, the more positive perception of the school climate, the smaller tendency of academic dishonesty behavior and vice versa. The importance of creating a school climate that is perceived positively can be used as an effort to prevent academic dishonesty such as cheating.
\end{abstract}

Key words : perception, school climate, academic dishonesty 
Pendidikan hakikatnya menjadi hal yang mendasar bagi setiap individu guna mencapai pengembangan diri, membentuk kepribadian dan identitas sosial. Selain itu, adapun tujuan pendidikan nasional Indonesia, yaitu mencerdaskan kehidupan bangsa dan mengembangkan manusia Indonesia seutuhnya, yaitu manusia yang beriman dan bertaqwa terhadap Tuhan Yang Maha Esa, berbudi pekerti luhur, memiliki pengetahuan dan ketrampilan, kesehatan jasmani dan rohani, kepribadian yang mantap dan mandiri serta memiliki rasa tanggung jawab kemasyarakatan dan kebangsaan. Akan tetapi pada kenyataanya, didalam proses pendidikan masih banyak kerap terjadi bentuk tindakan yang bertentangan dengan nilai integritas tersebut, terdapat banyak tindakan kecurangan, ketidakjujuran secara akademik dalam sistem pendidikan di Indonesia (Herdian, 2017;Panjaitan, 2017). Adapun tindakan / perilaku tersebut diantaranya pelanggaran kedisiplinan, plagiarisme, mencontek, dan sampai pembelian tugas akhir.

Berdasarkan data Indicators of School Crime and Safety 2016, yang dirilis oleh National Center for Education Statistic (2017) melaporkan, Indonesia merupakan salah satu diantara negara yang pada saat ini memiliki darurat tentang perilaku bermasalah di sekolah. Adapun prosentasenya $87 \%$ siswa memiliki perilaku bermasalah diantaranya pelanggaran kedisiplinan salah satunya ketidakjujuran akademik. Beberapa studi menyebutkan, masalah ketidakjujran akademik di Indonesia sudah dimulai pada taraf sekolah dasar (Nursalam dkk, 2013), hasil lainya pada SMA yang berbasis agama ketidakjujuran akademik mencapai 64,6\% ketika ujian (Herdian, 2017). Ironisnya pelaku ketidakjujuran akademik tidak menyadari hal tersebut sebuah tindak kesalahan dan perilaku yang normal yang dilakukan secara spontan. Disisi lain, perilaku ketidakjujuran akademik kerap direncanakan oleh siswa (seperti mencontek, plagiarisme) dan dianggap sebagai jalan untuk mengatasi kesulitan yang dihadapinya, meskipun mereka menyadari perilakunya sebuah tindakan yang melawan hukum bahkan dianggap kriminal (Molen, 2014).

Prevalensi perilaku ketidakjujuran akademik disekolah terjadi hampir setiap waktu, terlebih ketika pelaksanaan ujian berlangsung. Nilai yang besar dianggap sebagai tolak ukur keberhasilan bagi siswa ketika sekolah dan menjadi prestasi di mata masyarakat. Akan tetapi, pencapaian nilai besar / tinggi berpengaruh pada perilaku keseharian siswa disekolah, dan menjadi tekanan secara psikologis bagi siswa sehingga siswa cenderung melakukan segala cara untuk mencapainya, meskipun dalam prosesnya melakukan ketidakjujran akademik (McCabe et al., 2009; Norton et al., 2001). Adapun pelaku ketidakjujuran akademik dari sisi gender siswa laki - laki cenderung memiliki frekuensi lebih besar dibanding perempuan (Mujahidah, 2009; Pujiatni \& Lestari, 2010; Hensleya, Kirkpatricka \& Burgoonb, 2013). Hal yang lain, selain dari sisi gender, ketidak jujuran akademik dipengaruhi oleh faktor ekstrinsik (luar) salah satu diantaranya yaitu iklim lingkungan akademik. Terlebih pada mereka siswa usia remaja yang telah mampu memberikan penilaian terhadap fasilitas sekolah, kenyamanan, keamanan, keterikatan/rasa memiliki, serta kondisi / iklim lingkungan akademik. Penelitian Manguvo, Whitney \& Chareka (2011) menyebutkan bahwa ada hubungan antara persepsi siswa terhadap iklim sekolah dengan kecenderungan munculnya perilaku bermasalah, salah satu diantaranya perilaku ketidakjujuran akademik yang dilakukan didalam ketika ujian. 
Ketidakjujuran akademik menjadi hal yang sangat dilematis dalam ranah pendidikan, dan menghasilkan bentuk, jenis yang berbeda mengikuti perkembangan jamannya. Perilaku ketidakjujuran akademik dianggap sebuah ketidaksesuaian antara pengetahuan keilmuan akademisi dengan perilaku (McCabe, 2009; Pramadi, et.al, 2017), bahkan nilai religiusitas seseorang dengan perilaku (Herdian \&Astorini, 2017). Hal tersebut tidak menjadi jaminan ketika sesorang dengan tingkat keilmuan dan religiusitas yang tinggi tidak akan melakukan perilaku ketidakjujuran akademik, terlebih pada jaman digital pada saat ini. Mustapha et al, (2017) dari hasil penelitiannya dikatakan bahwa kemudahan dalam mengakses internet atau kemutakhiran teknologi yang menjadi penyebab ketidakjujuran akademik. Byrne \& Thrushell (2013) menyebutkan ketidakjujuran akademik yang terjadi dilingkungan akademik salah satu penyebabnya adalah teknologi. Adanya perubahan dalam aturan pembelajaran, ikut menjadi penyebab munculnya plagiarisme digital, perubahan pembelajaran menggunakan jaringan teknologi, akses yang tanpa batas, pengawasan dan kontrol yang rendah pada iklim sekolah yang kurang kondusif menjadi penyebab terjadinya fenomena ketidakjujuran dikalangan akademisi (Stogner, Miller \& Marcum, 2013) sehingga memunculkan persepsi dan perilaku yang kurang baik pada siswa ketika dicermati secara seksama.

Hal yang lain intepretasi siswa terhadap iklim sekolahnya dapat saja berbeda dengan keadaan sekolah yang sebenarnya. Mengingat persepsi merupakan hal yang bersifat subjektif sehingga hal inilah yang menjadi menarik untuk diteliti, karena meskipun persepsi siswa terhadap iklim sekolah yang positif, seperti sekolah yang telah menggunakan kurikulum berbasis pondok pesantren yang kental dengan iklim yang religius, masih dapat memiliki potensi dipersepsikan secara negatif oleh siswa. Rendahnya pengawasan dan peran pendidik yang kurang maksimal, dapat menyebabkan berbagai hal terkait persepsi negatif siswa sehingga menjadikan siswa kurang memiliki adanya pengendalian diri / kontrol diri pada diri siswa, terlebih ketika berada pada lingkungan sekolah dengan iklim yang tidak kondusif (Manguvo, Whitney \& Chareka, 2011). Persepsi negatif terhadap iklim sekolah berdampak pada berkurangnya integritas akademik pada diri siswa sehingga lebih cenderung kearah peluang melakukan tindakan melawan aturan seperti halnya ketidakjujuran akademik.

Gunarsa (2010) menyatakan bahwa pada dasarnya setiap manusia memiliki dorongan untuk melanggar aturan pada situasi tertentu. Akan tetapi, kebanyakan individu ketika memiliki dorongan untuk melanggar biasanya tidak diwujudkan dalam kenyataanya, hal tersebut terjadi karena individu normal biasanya dapat menahan diri dari dorongan dorongan untuk melakukan perilaku yang bermasalah. Kemampuan menahan, mengontrol diri dari perilaku ketidak jujuran akademik inilah yang seharusnya dipelajari dan diterapkan oleh remaja terlebih pada lingkungan sekolah yang berbasis pondok pesantren yang bernuansa religius. Paparan uraian diatas merupakan sebuah pertentangan antara harapan dan realita, sehingga hasil penelitian ini diharapkan mampu menjawab rumusan masalah, diantaranya; apakah persepsi terhadap iklim sekolah berhubungan dengan kemunculan perilaku ketidakjujuran akademik?.Adapun tujuan dari penelitian ini yaitu mengetahui hubungan persepsi terhadap iklim sekolah dengan kecenderungan perilaku ketidakjujuran akademik. 


\section{Ketidakjujuran akademik}

Ketidakjujuran akademik mengacu pada perilaku curang pada ranah akademik. Herdian (2017) mendefinisikan ketidakjujuran akademik sebagai bentuk kecurangan dan plagiarisme yang melibatkan siswa dalam memberi atau menerima bantuan yang tidak sah dalam latihan akademis atau menerima uang untuk pekerjaan yang bukan dilakukan oleh mereka sendiri. Pramadi et al, (2017) mengungkapkan bahwa ketidakjujuran akademik mencakup perbuatan menyontek, menipu, plagiarisme, dan pencurian ide, baik yang dipublikasikan atau tidak dipublikasikan. Selain itu, terdapat istilah lain ketidakjujuran akademik menurut Herdian\& Wulandari (2017) yaitu kecurangan Akademik (Academic Fraud) Kecurangan akademik merupakan berbagai bentuk perilaku yang mendatangkan keuntungan bagi mahasiswa secara tidak jujur, termasuk di dalamnya menyontek, plagiarisme, mencuri, dan memalsukan sesuatu yang berhubungan dengan akademis.

Adapun beberapa faktor yang mempengaruhi munculnya perilaku ketidakjujuran akademik (Mustapha et al, 2017) diantaranya;1). faktor situasional meliputi tekanan untuk mendapat nilai tinggi, kontrol atau pengawasaan selama ujian, kurikulum, pengaruh teman sebaya, ketidaksiapan mengikuti ujian, dan iklim akademis di institusi pendidikan. 2). Personal meliputi kurang percaya diri, self-esteem dan need approval, ketakutan terhadap kegagalan, kompetisi dalam memperoleh nilai dan peringkat akademis, dan self-efficacy. 3). Demografi meliputi jenis kelamin, usia, nilai, dan moralitas. 4). Perkembangan teknologi.

Jenis ketidakjujuran akademik pada beberapa hasil studi sangat beragam jenisnya, akan tetapi menurut Cizek (Anderman \& Murdock, 2007) perilaku kecurangan akademik merupakan perilaku yang terdiri atas tiga kategori yaitu (1) memberikan, menggunakan ataupun menerima segala informasi (2) menggunakan materi yang dilarang digunakan dan (3) memanfaatkan kelemahan seseorang, prosedur ataupun suatu proses untuk mendapatkan suatu keuntungan yang dilakukan pada tugas-tugas akademik. Adapun bentuk-bentuk ketidakjujuran akademik menurut McCabe (2009) yaitu: (a) bekerja sama dengan orang lain tetapi mengaku mengerjakannya sendiri; (b) mengutip dari suatu sumber tertulis dan atau sumber online tetapi tidak mencantumkannya di daftar pustaka; (c) mendapatkan bocoran pertanyaan atau jawaban tes dari orang lain; (d) menerima bantuan saat mengerjakan tugas; (e) memalsukan data penelitian; (f) menggunakan alasan palsu agar dapat menunda mengumpulkan tugas; (g) memalsukan daftar pustaka; (h) menyontek; (i) membantu teman mengerjakan ujian atau tes; (j) menyalin makalah milik orang lain; (k) menyalin sebagian besar tulisan; (l) menyalin hasil tes milik orang lain dan diketahui oleh orang tersebut; (m) membawa contekan saat ujian; (n) hanya setor nama saat tugas kelompok; dan (o) menyalin sebagian besar tulisan di web.

Perilaku bermasalah seperti halnya Ketidakjujuran akademik yang terjadi tidak terlepas dari dampak lingkungan sekitar seorang individu yang melakukanya (Marte, 2008). Teori belajar sosial Bandura yang berpengaruh pada teori biologi ekologi Bronfenbener menyebutkan adanya ketergantungan antara manusia dengan lingkunganya sehingga perilaku manusia yang ditampakan akibat adanya pola pembelajaran pada lingkungannya. Perilaku bermasalah berupa ketidakjujuran akademik, seperti mencontek 
dilingkungan sekolah ketika ujian, terjadi adanya proses moral kognisi lingkungan seperti persepsi, berfikir dan memproses informasi pada lingkungan (Velden, Brugman, Boom \& Koops, 2010). Dalam hal ini perilaku ketidakjujuran terjadi karena adanya pemrosesan informasi lingkungan sekolah yang tidak tepat oleh siswa.

\section{Persepsi terhadap Iklim Sekolah}

Iklim sekolah ( school climate) adalah suatu suasana atau kualitas dari sekolah untuk membantu individu masing-masing merasa berharga secara pribadi, bermartabat dan penting secara serentak dapat membantu terciptanya suatu perasaan memiliki terhadap segala sesuatu di sekitar lingkungan sekolah (Kassabri, Benbenisht \& Astor, 2005). Sedangkan menurut Purwita \& Tairas (2013) Iklim sekolah adalah suatu konstruk yang kompleks dan multidimensional yang meliputi suasana, budaya, nilai-nilai, sumber daya, dan peran sosial dari sebuah sekolah. Dapat dikatakan pula bahwa iklim sekolah merupakan "jiwa" dari sebuah sekolah, sedangkan persepsi terhadap iklim sekolah didefinisikan sebagai suatu penilaian, pemaknaan terhadap suasana, kualitas afiliasi pendidik, fasilitas (bangunan) dari sekolah untuk membantu peserta didik merasa nyaman secara pribadi dan sosial, perasaan memiliki terhadap segala sesuatu di sekitar lingkungan sekolah.

Purwita \& Tairas (2013) menyatakan bahwa persepsi terhadap iklim sekolah adalah kualitas penilaian yang relatif tetap kepada elemen lingkungan sekolah yang dirasakan oleh semua warga sekolah. Karakteristik inilah yang membedakan satu sekolah dengan sekolah yang lain, sehingga dapat mempengaruhi perilaku para warganya. Konsep iklim sekolah memiliki beberapa dimensi dan aspek yang berbeda-beda menurut para ahli. Pada teori lingkungan Moos, dimensi iklim lingkungan sekolah yang terdapat dalam Purwita \& Tairas (2013) yaitu dimensi hubungan (relationship), dimensi perkembangan pribadi (personal development), dimensi perubahan dan perbaikan sistem (system maintenance and change) dan dimensi lingkungan fisik (phyisical environment). Adapun 4 dimensi iklim sekolah yaitu dimensi hubungan, dimensi perkembangan pribadi, dimensi perubahan, perbaikan sistem, dan dimensi lingkungan fisik.

Kassabri, Benbenishty \& Astor (2005) juga membagi aspek persepsi terhadap iklim sekolah atas tiga aspek, diantaranya(1).School Bonding yaitu, kejelasan peraturan sekolah terhadap perilaku yang melanggar, kejelasan ini terjadi secara konsisten dan peraturan yang adil, meliputi pertimbangan para siswa mengenai kebijakan sekolah atau prosedur yang mengarah pada pengurangan kekerasan.(2). Teacher support of students yaitu, dukungan yang diberikan guru / tenaga pengajar terhadap siswa meliputi hubungan / afiliasi guru dengan siswa yang dapat mendukung siswa.(3). Students engagement yaitu, sejauh mana keterlibatan siswa dalam pembuatan keputusan dan rancangan intervensi untuk pencegahan masalah di sekolah. Dalam penelitian ini, penulis lebih menggunakan aspek iklim sekolah yang dijadikan acuan dalam mengukur persepsi / pandangan responden bagaimana peran siswa dalam melihat isu masalah perilaku di sekolah. 


\section{Persepsi terhadap Iklim Sekolah dengan Kemunculan Perilaku Ketidakjujuran Akademik}

Iklim dari lingkungan sekolah merupakan salah satu faktor penting yang mempengaruhi performa siswa di sekolah. Mental health in school UCLA center (2008) melansir hasil penelitianya bahwasanya, akibat kualitas lingkungan sekolah yang rendah dapat meningkatkan siswa menjadi menghindari sekolah, merasa tidak mampu, sehingga melakukan segala cara yang melanggar aturan seperti mencontek, plagiasi guna mengatasi kesulitannya. Zahid (2014) menyatakan persepsi terhadap iklim sekolah yang negatif mempengaruhi penyesuaian siswa terhadap lingkungan dan menyebakan terjadinya masalah perilaku di sekolah. Hal yang sama, berdasarkan hasil penelitian Wang \& Dishion (2011) yang menguji persepsi siswa remaja terhadap tiga aspek iklim sekolah dengan masalah perilaku disekolah menunjukan adanya hubungan negatif yang signifikan disetiap aspek iklim sekolah yang positif. Selain itu, diungkapkan oleh penelitian Omoteso \& Semudra (2011) iklim manajemen kelas dan efektivitas hubungan dengan guru berperan dalam menekan terjadinya perilaku mencontek disekolah.

Persepsi terhadap iklim sekolah memiliki dampak langsung dan tidak langsung terhadap prestasi akademik seorang siswa (perfomance academic) dalam lingkungan sekolah (Mitchell, 2010). Hasil riset yang di lansir oleh Brackett, Elbertson \& Susan (2011) munculnya masalah perilaku ketidakjujuran akademik pada siswa berhubungan signifikan dengan iklim sekolah yang tercipta, terlebih iklim di dalam kelas (classroom climate) serta afiliasi siswa dengan guru. Hal tersebut menunjukan peran iklim sekolah terutama iklim yang terbentuk di kelas serta peran pengawasan tenaga pengajar / guru yang kurang maksimal dapat mempengaruhi munculnya masalah perilaku ketidakjujuran akademik pada siswa ketika di sekolah.

\section{METODE}

Desain penelitian ini menggunakan pendekatan kuantitatif. Teknik pengambilan sampel yang dilakukan adalah Purposive Sampling. Dalam penelitian ini, menggunakan sampel berjumlah 120 siswa, kelas XII di SMAN Darusholah Singojuruh Banyuwangi semua jurusan. Alasan menggunakan responden dari sekolah ini, di sekolah tersebut menggunakan sistem kurikulum berbasis pondok pesantren, menerapkan pendidikan karakter yang religius dengan pola kedisiplinan yang baik. Skala persepsi iklim sekolah yang digunakan dalam penelitian yaitu School Climate Scale (SCC) dari Dewey Cornell (2015) terdiri 24 item pernyataan. Skala ketidakjujuran akademik menggunakan Academic Dishonesty Scale (ADS) dari Bashir \& Bala (2018), terdiri dari 23 item pernyataan. Prosedur pengumpulan data dilakukan dengan pengisisan kuesioner, kemudian pengolahan data, adapun tahapanya yaitu coding, scoring dan tabulasi. Analisis data menggunakan korelasi regresi product moment dengan bantuan SPSS 20 for windows. 


\section{HASIL}

Dalam penelitian ini, menggunakan sampel berjumlah 120 siswa, berdasarkan karakteristik subjek penelitian ditunjukkan dalam bentuk tabel sebagai berikut:

Tabel.1 Deskripsi variabel penelitian $(n=120)$

\begin{tabular}{lll}
\hline Karakteristik & N & $(\boldsymbol{\%})$ \\
\hline Siswa jurusan & & \\
$\quad$ XII IPA & 67 & 56 \\
XII IPS & 31 & 27 \\
XII Bahasa & 22 & 17 \\
Jenis kelamin & & \\
Laki - laki & 46 & 38 \\
Perempuan & 74 & 62 \\
\hline
\end{tabular}

\section{Instrumen penelitian}

Skala persepsi iklim sekolah yang digunakan dalam penelitian yaitu School Climate Scale (SCC) dari Dewey Cornell (2015) terdiri 24 item pernyataan dengan nilai reliabiltas sebesar $=0,87$. Setelah di uji cobakan diperoleh nilai reliabilitas $\alpha=0,731$ dan Masing - masing pernyataan disertai dengan empat pilihan jawaban yaitu, sangat setuju $(\mathrm{SS})=4$, setuju $(\mathrm{S})=3$, tidak setuju $(\mathrm{TS})=2$, dan sangat tidak setuju $(\mathrm{STS})=1$.

Skala yang digunakan mengukur ketidakjujuran akademik di sekolah Academic Dishonesty Scale (ADS) dari Bashir \& Bala (2018), terdiri dari 23 item. Masing - masing pernyataan disertai dengan empat pilihan jawaban yaitu, Tidak Pernah $(\mathrm{TP})=1$, dua kali Kadang-kadang $(\mathrm{K})=2$, Pernah $(\mathrm{P})=3$, Selalu $(\mathrm{S})=4$. Hasil uji reliabilitas diperoleh nilai sebesar $\alpha=0,799$

\section{Deskripsi variabel penelitian}

Hasil skor total masing-masing variabel berdasarkan pedoman penskoran pada alat ukur diperoleh Persepsi terhadap iklim sekolah $(M=49,97 ; S D=5,197)$ pada rentangan $=35$ 60, menunjukkan persepsi terhadap iklim sekolah pada siswa kelas XII IPA, IPS dan Bahasa di SMAN Darrussholah dalam kategori positif. Variabel ketidakjujuran akademik diperoleh $(M=50,68 ; S D=8,124)$ pada rentangan= $27-77$, menunjukan tingkat ketidakjujuran akademik pada siswa dalam kategori Sedang. Hal tersebut menunjukan perilaku mencontek (ketidakjujuran akademik) masih cenderung terjadi. Untuk lebih jelas dapat dilihat pada tabel berikut :

Tabel 2. Deskripsi variabel penelitian

\begin{tabular}{llll}
\hline \multicolumn{1}{c}{ Variabel } & Rentang skor & \multicolumn{1}{c}{$\boldsymbol{M}$} & \multicolumn{1}{c}{$\boldsymbol{S D}$} \\
\hline Persepsi iklim sekolah & $\mathbf{3 5 - 6 0}$ & $\mathbf{4 9 , 9 7}$ & $\mathbf{5 , 1 9 7}$ \\
Ketidakjujuran akademik & $\mathbf{2 7 - 7 7}$ & $\mathbf{5 0 , 6 8}$ & $\mathbf{8 , 1 2 4}$
\end{tabular}




\section{Hubungan antar variabel}

Hasil korelasi antar variabel ditunjukkan dalam bentuk tabel sebagai berikut:

Tabel 3. Korelasi antar variabel

\begin{tabular}{lcc}
\hline \multicolumn{1}{c}{ Persepsi Iklim Sekolah } & Ketidakjujuran Akademik \\
\hline Persepsi iklim sekolah & 1 & $-0,129^{*}$ \\
Ketidakjujuran Akademik & & 1 \\
\hline
\end{tabular}

Keterangan: $* \mathrm{p}<0,05$

menguji korelasi antar variabel digunakan metode product moment pearson dengan $p<0,05$ sebagai kriteria signifikansi. Tabel 3 memperlihatkan hasil analisis berupa koefisien korelasi pearson beserta taraf signifikansinya. Interpretasi dari hasil tersebut adalah persepsi iklim sekolah berkorelasi signifikan terhadap perilaku ketidakjujuran akademik. Angka koefisien negatif pada persepsi iklim sekolah terhadap perilaku ketidakjujuran akademik memiliki arah yang berbanding terbalik, yaitu semakin positif persepsi iklim sekolah, maka semakin rendah kemunculan perilaku ketidakjujuran akademik, begitu pula sebaliknya. Adapun kontribusi persepsi iklim sekolah terhadap diperoleh $(r=-0.129 ; p=0,15)$ hal tersebut artinya $12,9 \%$ sumbangan persepsi iklim sekolah terhadap perilaku ketidakjujuran akademik sisanya disebabkan variabel - variabel lainya.

\section{DISKUSI}

Hubungan negatif yang cukup signifikan pada persepsi iklim sekolah yang diperoleh dari analisis data, menunjukan persepsi terhadap iklim sekolah memberikan peran yang berarti dalam membentuk perilaku pada diri individu tidak terkecuali pada diri siswa dilingkungan sekolah. Hal tersebut menunjukan dimensi iklim sekolah khususnya lingkungan fisik dan hubungan antar pendidik dengan siswa, akan membentuk penilaian / persepsi sehingga siswa memiliki evaluasi dan iklim sekolah memiliki pengaruh pada diri siswa, dalam memutuskan untuk bertindak. Terlebih pada perilaku yang bersifat melanggar aturan seperti melakukan ketidakjujuran akademik.

Faktor eksternal seperti iklim lingkungan sekolah dalam penelitian ini terbukti memberikan pengaruh dalam pembentukan perilaku ketidakjujuran akademik pada siswa. Hal tersebut sesuai dengan teori pembelajaran sosial oleh Albert Bandura yang mengemukakan bahwa perilaku individu dipengaruhi oleh lingkungan melalui penguat (reinforcement). Sehingga demikian pula yang terjadi ketika iklim sekolah yang kondusif sebagai penguat dapat mempengaruhi perilaku dari individu disekitarnya. Oleh karena itu, membentuk persepsi yang positif terhadap iklim sekolah penting untuk ditingkatkan dalam menekan munculnya perilaku ketidakjujuran akademik. 
Penelitian lain yang dilakukan Giallo \& Little (2003) mengemukakan bahwasanya perilaku bermasalah seperti salah satunya mencontek pada siswa, diawali dari situasi lingkungan terkecil mereka yaitu kelas yang tidak kondusif. Hasil penelitian tersebut menyebutkan situasi kelas yang tidak kondusif, karena elemen dilingkungan sekolah yang tidak terkontrol, sehingga siswa leluasa melakukan perilaku yang melanggar aturan seperti ketidakjujran akademik. Penelitian Sun (2014) juga menyebutkan siswa cenderung melakukan perilaku yang tidak semestinya karena lingkungan yang tidak kondusif memberikan kesempatan mereka untuk melakukanya. Hal tersebut menunjukan lingkungan sekolah berperan dalam perilaku yang ditampakan oleh seluruh warganya.

Iklim sekolah yang kondusif atau tidak, tetap akan memberikan penilaian dan evaluasi oleh individu disekitarnya. Akan tetapi, iklim sekolah yang kondusif, terpenuhi dimensi lingkungan fisik, hubungan pendidik dengan siswa, peraturan yang mengikat dan berintegritas dapat memberikan persepsi yang positif sehingga mempengaruhi perilaku individu di sekitarya. Hal tersebut sesuai dengan hasil penelitian Razak (2006) yang menyatakan bahwa persepsi terhadap iklim sekolah yang berkesan positif mempengaruhi perilaku, motivasi, integrasi serta keharmonisan antara siswa dengan guru. Penelitian ini juga sejalan dengan hasil penelitian Sari (1998) menyebutkan iklim sekolah yang positif adalah indikator kuat dalam pembentukan sikap (akhlak) serta karakter (kepribadian) siswa. Hasil penelitian tersebut dapat memperkuat bahwa persepsi iklim sekolah yang positif dapat membantu menurunkan kemunculan perilaku ketidakjujuran akademik.

Siswa yang memiliki persepsi positif terhadap iklim sekolah akan memiliki perasaan aman, nyaman dan bangga menjadi bagian dari sekolahnya, maka aturan yang diterapkan akan selalu ditaati dan dirasa tidak memberatkan bagi siswa, sehingga perilaku ketidakjujran akademik cenderung tidak dilakukan. Data di lapangan menunjukan bahwa persepsi iklim sekolah pada siswa SMAN Darussholah Singojuruh Banyuwangi kels XII jurusan IPA, IPS dan Bahasa secara umum cukup positif, akan tetapi masih ditemukan kecenderungan melakukan perilaku ketidakjujuran akademik (mencontek) sebesar 12,9\%. Hal tersebut menunjukan iklim sekolah dengan penerapan berbasis pondok pesantren atau tidak, seperti halnya iklim sekolah berbasis umum - regular, nasionalis masih sama - sama memiliki peluang kecenderungan terjadi praktek ketidakjujuran akademik pada siswanya, meskipun sudah dipersepsikan secara positif.

\section{SIMPULAN DAN IMPLIKASI}

Berdasarkan analisis hasil penelitian, meskipun iklim sekolah dengan berbasis pondok pesantren dengan penerapan pendidikan karakter yang kuat, masih terdapat praktek ketidakjujuran akademik oleh siswa. Hasil penelitian, dapat disimpulkan bahwa ada hubungan negatif yang signifikan antara persepsi iklim sekolah yang positif dengan perilaku ketidakjujuran akademik. Semakin positif persepsi siswa terhadap iklim sekolah maka semakin rendah kemunculan perilaku ketidakjujuran akademik seperti diantaranya mencontek. Sebaliknya, persepsi negatif terhadap iklim sekolah maka akan secara signifikan meningkatkan kemunculan perilaku ketidakjujuran akademik. 
Penelitian ini telah menunjukan bahwa persepsi iklim sekolah yang positif memiliki peran yang cukup penting dalam proses belajar di lingkungan sekolah. Suasana yang tercipta dari persepsi positif dapat menumbuhkan keharmonisan hubungan antara siswa dengan guru dan tenaga kependidikan lainya. Oleh karena itu sangat penting menciptakan iklim sekolah yang kondusif sehingga di persepsikan secara positif oleh siswa, karena iklim sekolah yang membedakan satu sekolah dengan sekolah lainya, hal tersebut akan berdampak sangat positif pada perilaku yang di tampakan oleh siswa. Persepsi iklim sekolah memberikan kontribusi sebesar 12,9\% terhadap kemunculan perilaku ketidakjujuran akademik. Hasil penelitian ini memberikan peluang kepada peneliti selanjutnya untuk melakukan penelitian dengan mempertimbangkan faktor intrisik lainya yang dapat mempengaruhi kemunculan perilaku ketidakjujuran akademik.

\section{REFERENSI}

Anderman, E. M., \& Murdock, T. B. (2007). Psychology of academic cheating. Amsterdam: Elsevier Academic Press.

Bashir, H. (2017). Development and Validation of Academic Dishonesty Scale: Presenting a Multidimensional Scale. Journal International of Instruction, 2(11). e-ISSN;1308-1470, p-ISSN:1694-609X.

Bolin, A. U. (2004). Self control, Perceived Opportuniity and Attitudes as Predictors of Academic Dishonesty. The Journal of Psychology, 138(2), 101-114.

Byrne, K. \& Thrushsell. (2013). Education undergraduates and ICT-enhanced academic dishonesty: A Moral panic?. British Journal of Educational tecnology, 44(1), 619.

Endra, M. S.(2013). Pensinergian Mahasiswa, Dosen dan Lembaga Dalam Pencegahan Kecurangan Akademik Mahasiswa Akuntansi. Jurnal Pendidikan Akuntansi Indonesia, XI(2), 54-67.

Giallo, R., \& Little, E. (2003). Classroom behavior problem: The relationship between preparedness, classroom experiences, and self-efficacy in graduate and student teachers. Australian of Education \& Development Psychology, 3, 21-34.

Hensleya, Kirkpatricka \& Burgoonb. (2013). Relation of Gender, Course Enrollment and Gradeto Distint Form of Academic Dishonesty. Teaching in Higher Education, 18(8), 895-907.

Herdian \& Wulandari, D. A. (2017). Ketidakjujuran pada Calon Pendidik Agama Islam di Universitas X di Purwokerto. Psikologia Jurnal Psikologi, 2(1), 1-16. ISSN 2338-8595, ISSN 2541-2299.

Herdian. (2017). Ketidakjujuran akademik pada saat UNBK Tahun 2017. Jurnal Psikologi Jambi, 2(2), p-ISSN : 2528-2735, e-ISSN : 2580-7021. 
Kassabri, Benbenishty, \& Astor. (2005). The effect of school climate, sosioeconomics and cultural factors on student victimization in israel. Journal of social work research, 29(3), 165-180.

Lawson, R. A. (2004). Is Classroom cheating related to business students' propensity to cheat in the realworld?. Journal of usiness Ethic, 49(2), 189-199.

Lestari, S., \& Adiyanti, M. G. (2012). The Concept of Honesty in JavanesePeople's Perspective. Anima, 27(3). 129-142.

Manguvo, A., Withney, S., \& Chareka, O. (2011). The crisis of school misbehaviour in zimbabwean public schools: Teachers' perceptions on impact of macro socioeconomics challenges. Journal of the African Educational Research Network, 11 (2), 155-162.

Marte, M. R. (2008). Adolescent Problems Behaviors. New York: LFB Scholarly Publishing LLC.

McCabe, D. (2009). Academic dishonesty in nursing schools: An empirical investigation. Journal of Nursing Education, 48(11), 614-23.

Molen, A. R. (2014). Academic Dishonesty and Misconduct: Curbing Plagiarism in the Muslim World. Intellectual Disconfrence, 22(2). 167.

Mujahidah (2009). Perilaku menyontek laki-laki dan perempuan Studi Meta Analisisis. Jurnal Psikologi, 2(2), 177-199.

Mustapha, Ramlan; Hussin, Zaharah \& Siraj, Saedah. (2017). Analisis Faktor Penyebab Ketidakjujuran Akademik dalam kalangan Mahasiswa : Aplikasi teknik : Fuzzy Delphi. Juku : Jurnal Kurikulum \& Pengajaran Asia Pasifik, 5(2).

National Center for Education Statistic. (2017). Indicators of School Crime and Safety: 2016. di akses 29 September 2018, http://nces.ed.gov/pubsearch/ pubsinfo.asp?pubid=2011002.

Norton, L. S., Tilley, A., Newstead, S., \& Franklyn-Stokes, A. (2001). The pressures of assessment in undergraduate courses and their effect on student behaviours. Assessment \& Evaluation in Higher Education, 26(3), 269-284.

Nursalam, Bani, S., \& Munirah. (2013). Bentuk Kecurangan Akademik (Academic Cheating) Mahasiswa PGMI Fakultas Tarbiyah Dan Keguruan Uin Alauddin Makassar. Lentera Pendidikan, 16(2). 127-138.

Omesoto, B. A., \& Semudara, A. (2011). The relationship between teachers' effectiveness and management of classroom misbehaviours in secondary schools. Scientific Reseach Psychology, 2(9), 902 - 908. 
Panjaitan, E. D. (2017). Student Cheating in National Examinations: A case of Indonesia. Dissertation. Osaka Jogakuin University

Pramadi, A., Pali, M., Hanurawan, F. \& Atmoko. A. (2017). Academic Cheating In School: A Procces of Dissonance Between Knowledge and Conduct. Mediterranean Journal of Social Sciences, 8(6). ISSN 2039-211, ISSN 20399340.

Purwita, H. F., \& Tairas. (2013). Hubungan antara persepsi siswa terhadap Iklim sekolah dengan school engagment di SMK IPIEMS Surabaya. Jurnal Pendidikan dan Perkembangan,2 (1), 1-9.

Razak, A. Z. A. (2006). Ciri iklim sekolah berkesan: Implikasinya terhadap motivasi pembelajaran. Jurnal Pendidikan, 31, 3 - 19.

Sari, Mahdi, D. (1998). Iklim Dini di Sekolah. Jurnal Dakwah, 1(1), 33 - 47.

Stogner. J. M, \& Miller, B. (2012). Learning E-cheat: A Criminological test of internet facilitated Academic cheating. Journal of Criminal Justice Education, 1-25.

Straw, D. (2002). The Plagiarism of Generation "why not?". Community College week, 14. 4-7.

Sun, Rachel, C. F. (2014). Is school misbehavior a decision? implications for school guidance. International Journal of Social, Behavioral, Educational, Economic and Management Engineering, 8(7), 2030-2034.

UCLA Center. (2008). Rethinking how schools address schools misbehavior \& disenggagement. Mental Health In School Program and Policy Analisis, 13(2), 156-159.

Velden, V. F., Brugman, D., Boom, J., \& Koops, W. (2010). Moral cognitive processes explaining antisocial behaviour in young adolescents. International Journal of Behavioral Development, 34(4), 292-301.

Wang, M., \& Dishion, T. J. (2011). The trajectories of adolescents' perceptions of school climate, deviant peer affiliation, and behavioral problems during the middle school years. Journal of Research on Adolescence, 22(1), 40-53.

Williams. M.S. \& Hosek.(2003).Strategis For Reducing Academic Dishonesty. Journal of Legal Studies Education, 21. 87

Yulianto, H. (2015). Persepsi Mahasiswa tentang Ketidakjujuran Akademik: Studi Kasus Mahasiswa Program Vokasi Universitas Indonesia. Jurnal Vokasi Indonesia, $3(1)$.

Zahid, Gulnaz. (2014). Direct and indirect impact of perceived school climate upon student outcomes. Journal Asian Social Science, 3(1),70-78. 


\title{
EKSPLORASI DAN PENGEMBANGAN SKALA $Q A N A$ ' $A H$ DENGAN PENDEKATAKAN SPIRITUAL INDIGENOUS
}

\author{
Awaludin Ahya \\ Fakultas Psikologi Universitas Surabaya Program Studi Magister Sains \\ awaludinahya.psy@gmail.com
}

\begin{abstract}
Abstrak. Tujuan penelitian ini adalah untuk mengeksplorasi konstrak Qana'ah berbasis spiritual indigenous. Open Ended Questionaire dalam penelitian ini digunakan untuk menemukan beberapa faktor pembentuk dari konstrak Qana'ah. Sebanyak 259 responden mengisi Open Ended Questionaire dan menemukan beberapa aspek pembentuk Qana'ah, termasuk menerima apa adanya dan selalu bersyukur, sabar dan berserah serta selalu berusaha. Dari aspek yang ditemukan, tahap berikutnya adalah mengembangkan instrumen menggunakan model Likert 5-pilihan. Kemudian, uji coba skala dilakukan dengan 150 responden. Hasil akhir dari penelitian ini menemukan 3 aspek Qana'ah melalui analisis faktor eksploratori, yakni aspek Menerima apa adanya dan Bersyukur, aspek Sabar dan Berserah, serta aspek Selalu Berusaha.
\end{abstract}

Kata kunci: Analisis Faktor Eksplorasi, Skala Qana'ah, Spiritual Indigenous.

Abstract. The purpose of this study was to explore the factor of Qana'ah using Spirituals Indigenous approach. The Open Ended Questionnaire in this study was used to find the forming factors and dimension of Qana'ah. A total of 259 respondents filled the Open Ended Questionnaire and found several aspects of the formation of Qana'ah, including accepting what they are and always grateful, Be Patient and Surrender, and always tried. From the aspect found, the next stage was developing instrument using a 5-choice Likert model. Then, the trial test was conducted with 150 respondents. The final results of this study found 3 aspect of Qana'ah through exploratory factor analysis, namely aspects of Accepting what is and Gratitude, aspects of Patience and Surrender, and aspects of Always Trying.

Keywords: Exploration Factor Analysis, Qana'ah Scale, Spiritual Indigenous. 
Penerapan perspektif religius dan spiritual dalam riset maupun pegembangan alat ukur psikologi sudah dilakukan beberapa peneliti dari berbagai Institusi baik skala nasional maupun pada skala internasional beberapa tahun terakhir, namun pengembangan alat ukur yang secara General (dimulai dari teori kemudian di lakukan konstruksi ke dalam indikator) terkadang tidak relevan dengan konteks-konteks latar belakang subyek atau responden. Konteks latar belakang subyek ini bisa meliputi budaya, sosial, filosofi maupun spiritual dan ekologi dari subyek. Indigenous psychology membeberikan pendekatan yang baru dalam sejarah riset psikologi, termasuk juga pada konteks pengembangan instrumen psikologi. Penelitian ini mengkaji secara eksplortif dan sebagai langkah awal pengembangan alat ukur Qana'ah berbasis indigenous psychology.

Sejatinya konteks-konteks yang melatarbelakangi individu diatas dapat mewarnai kekhasan perilakunya, walaupun secara tidak langsung, hal ini juga berkaitan dengan karakteristik bawaan individu. Kim (2006) berpendapat bahwasanya budaya maupun konteks-konteks lainya memiliki peran dalam perilaku manusia dari suatu masyarakat tertentu yang khas, atau disebut perilaku masyarakat dalam sebuah konteks, budaya menurutnya dipelajari secara Quasi independen pada perilaku individu. Indigenous Psychology hadir sebagai pendekatan yang mengkaji perilaku manusia secara lebih mendalam berdasarkan konteks latar belakang ke-khasan perilakunya. Dibandingkan dengan pendekatan psikologi umum (general psychology), Indigenous Psychology lebih mengkonstruksikan atribut psikologi pribumi dari hasil penelitianya, hal inilah yang membuat Indigenous Psychology lebih memperhatikan People In Context, yakni memandang perilaku manusia melalui berbagai macam konteks dalam pendekatanya.

Pada budaya timur, konteks spiritual dan budaya memberikan pengaruh lebih terhadap proses mental dan perilaku masyarakatnya, masyarakat timur yang umumnya memiliki beragam budaya tentunya akan menghasilkan keberagaman pula pada cara pandang, filosofi, gaya interaksi dan perilakunya. Spiritualitas mewarnai masyarakat timur dalam cara pandang, penyikapan perasaan, interaksi, maupun perilaku. Misalanya cara pandang masyarakat timur dalam hal kebahagiaan, penelitian yang dilakukan Rutt Veenhoven (Veenhoven, 2012) menemukan bahwa cara pandang masyarakat antar negara berbeda satu sama lain, sedangkan similaritas cara pandang mengenai kebahagiaan baru dapat ditemukan pada konteks lintas benua. Salah satu indikasi dalam memandang kebahagiaan pada masyarakat asia adalah, apabila sudah tepenuhinya kewajiban akan perintah Agama maupun tujuan yang transenden atau spiritual orientation. Di Indonesia, secara umum masyarakat memandang kebahagiaan juga di warnai dengan spiritualitas, seperti pada penelitian Anggoro dan Widiharso (2010) menemukan bahwa salah satu aspek kebahagiaan masyarakat di Indonesia adalah kebutuhan akan spiritualitas. Spiritualitas juga memiliki hubungan dengan pandangan mengenai kualitas hidup, asumsi ini diperkuat dengan temuan pada studi meta-analysis, dari studi tersebut korelasi bivariat yang menghasilkan Effect Size sedang antara spiritualitas dan kualitas hidup, yakni sebesar $r=0,34,95 \%$ CI: 0,28-0,40 (Sawatzky, Ratner, \& Chiu, 2005). Hal ini mengindikasikan bahwa spiritualitas memiliki ke-eratan hubungan yang moderat dengan kualitas hidup di berbagai studi.

Sejatinya budaya dan spiritualitas memiliki peran yang hampir seimbang dalam mewarnai keunikan manusia dalam berperilaku. Di Indonesia pemaknaan kata 
spiritualitas memiliki dwi persepsi, pada dekade awal pemerintahan di Indonesia istilah spiritualitas memiliki makna yang menunjuk keberagamaan sebuah tradisi yang secara kontekstual berbasis pada mistisisme agama-agama lokal misalnya aliran (sekte) Kepercayaan maupun Kebatinan. Saat ini spiritualitas dapat dimaknai sebagai ekspresi batin keber-agamaan atau dalam istilahnya disebut inner religious expression (Muttaqin, 2012). Spiritualitas dan agama dapat saling mewarnai dalam bentuk aliran keagamaan, hal ini dikarenakan terjadinya proses akulturasi antara agama dengan budaya lokal yang memiliki nilai maupun falsafah spiritual, misalnya dapat kita lihat melalui keberagaman tradisi ber-agama di Indonesia, misalanya aliran Islam Abangan, Kristen Kejawen, hindu bali dll.

\section{KAJIAN LITERATUR}

\section{Spiritual}

Spiritualitas adalah pikiran, perasaan, dan perilaku yang terkait dengan pencarian, atau perjuangan untuk memahami dan berkaitan dengan yang transenden (Hill, 2000). Spiritualitas juga dapat dimaknai sebagai orientasi internal individu menuju realitas transenden yang mengikat semua hal menjadi satu kesatuan yang harmonis (Dy-Liacco dkk, 2009). Religiusitas dan spiritualitas memiliki perbedaan walaupun dalam aplikasinya saling berhubungan, dalam religiusitas terkandung dasar keyakinan teologi, pedoman, metode, praktek ibadah, dan membantu individu memahami pengalaman hidupnya sedangkan Spiritualitas tidak memiliki dasar keyakinan teologis maupun praktek ibadah, namun memiliki kesamaan fungsi yakni membantu individu memahami pengalaman hidupnya (Amir \& Lesmawati, 2016). Lebih spesifik menurut kamus American Psychologycal Association (APA), spiritualitas memiliki definisi kepedulian dan patuh kepada Tuhan, dibuktikan dalam sikap maupun perilaku spiritual, serta kepekaan terhadap pengalaman religius, yang mungkin termasuk melalui praktik agama tertentu tetapi mungkin juga tanpa adanya praktik seperti itu (VandenBos, 2013), Hal ini memiliki arti bahwa spiritualitas sebenarnya berbeda tipis dengan religiusitas, Pada budaya barat seperti di Amerika, spiritual dipandang erat dan berkaitan dengan budaya (Samovar, Larry, Richard Porter, 2009).

Spiritualitas dan agama memiliki tujuan dan maksud yang sama yakni kedamaian batin, ikatan dengan alam, pencarian arti hidup dan hal lainya (Samovar, Larry, Richard Porter, 2009). Bagi masyarakat Indonesia spiritualitas dimaknai sebagai cerminan ekspresi dalam ber-agama (Muttaqin, 2012). Keberagaman inilah yang membuat spiritualitas dapat terkonteks sebagai kajian indigenous psychology.

\section{Indigenous Psychology}

Indigenous Psychology yang merupakan kajian mengenai perilaku maupun mental manusia yang bersifat pribumi menekankan kajian fenomena psikologi dalam konteks, keluarga, filosofis, politik, sosial, ekologi religius dan kultural (Kim dkk., 2006). Indigenous Psychology bukanlah sebuah studi mengenai orang pribumi melainkan studi tentang orang asli yang tinggal pada masyarakat, dimana Indigenous Psychology 
memegang asumsi bahwa hanya pribumi yang dapat memahami fenomena psikologi lokal (Faturochman, Wenty, \& Tabah, 2017). Indigenous Psychology tidak membatasi metode khusus dalam pendekatanya, pada penerapanya Indigenous Psyhology memiliki dua titik awal yakni indigenisasi dari dalam dan indigenisasi dari luar. Bukti adanya Indigenous Psychology adalah temuan konsep-konsep lokal yang sudah dianalisis dalam sebuah kajian maupun penelitian (Kim dkk., 2006). Sebagai Negara dengan keberagaman budaya, Indonesia sangat kaya akan objek fenomena dari Indigenous Psychology. Penenlitian ini melibatkan responden masyarakat lokal yang merepresentasikan konteks masyarakat Islam Indonesia saat ini.

\section{Qana'ah}

Islam di Indonesia merupakan agama mayoritas dengan penganut terbesar, yakni sebesar 87\% atau sekitar 207 juta dari total populasi penduduk nasional (BPS, 2010). Sebagai agama mayor Islam di Indonesia memiliki beberapa aliran spiritual baik dalam skala kampung maupun pada skala masyarakat, dapat kita lihat keberagaman spiritual masyarakat muslim di Indonesia, hal ini disebabkan dari berbagi budaya dan tradisi sejarah perkembangan Islam di Indonesia. Spiritualitas dalam ajaran Islam dapat dikaji pada ilmu Tasawuf, dimana tasawuf adalah ilmu untuk mengetahui bagaimana menjernihkan akhlak, mensucikan jiwa membangun dhahir dan batin serta mendekatkan diri kepada Allah SWT. (Nasution dkk., 2013 ; Zaini, 2016).

Pada ajaran Islam, spiritualitas dalam beragama dapat dilihat dari perbuatan maupun perilaku seseorang dalam menjalani kehidupan sehari-hari. Perilaku tersebut merupakan cerminan dari sifat yang ada dalam diri individu. Ajaran Islam memandang sifat adalah sebagai akhlak. Al Ghazali menyatakan bahwa akhlak bersumber dari kata al-khalqu yang artinya kejadian dan al-khuluqu yang artinya perilaku (Lubis, 2012). Lebih lanjut Al Ghazali memapaprkan bahwa Seseorang tidak dapat sempurna dengan hanya indah secara fisik jasmaniahnya saja, melainkan haruslah kesmuanya indah, yang mana bukan hanya dhahir melainkan juga indahnya batin, hal ini sebagai upaya tercapai akhlak baik (Lubis, 2012). Perumpamaan dari Al ghazali tersebut mengindikasikan bahwa keindahan bukan hanya pada paparan fisik (luar) saja melainkan juga pada batin (jiwa/dalam) supaya dapat berperilaku baik (hasil dari akhlak baik). Dalam Al-Quran akhlak baik dapat kita kaji melalui firman Allah SWT. :

"Maka maafkanlah mereka dan biarkan mereka, sesungguhnya Allah menyukai orang-orang yang berbuat baik. (Surat Al Maidah ayat 13)”.

Qana'ah merupakan sifat terpuji yang mencerminkan perilaku rela, merasa berkecukupan sabar, ikhlas serta tawakal kepada Allah SWT. Syukur, sabar, ikhlas, lapang dada, jujur, dermawan, rendah hati (tawadhu'), amanah, pemaaf, dan Qana'ah merupakan akhlak baik (Mujib, 2012). Qana'ah yang merupakan sebuah sifat dapat dikaji sebagai konstruk psikologi, Qana'ah dapat kita kaji melalui firman Allah SWT. yang termaktub dalam Surah Al-Baharaah Ayat 155 
"Dan sungguh akan Kami berikan cobaan kepadamu, dengan sedikit ketakutan, kelaparan, kekurangan harta, jiwa dan buah-buahan. dan berikanlah berita gembira kepada orang-orang yang sabar. (Al Baqarah : 155).

Qana'ah juga dapat dikaji dalam hadits, Rasulullah Shallallahu'alaihi Wa Sallam bersabda, "Sungguh beruntung orang yang berislam, memperoleh kecukupan rezeki dan dianugerahi Qana'ah atas segala pemberian" (Hasan. HR. Tirmidzi). Sufistik clasik seperti Abdul Qadir Al Jailani menafsirkan Qana'ah itu aktif, yaitu menyuruh percaya yang benar-benar akan adanya kekuasaan yang melebihi kekuasaan manusia, tetapi tetap kita berusaha mencari rizki, menyuruh sabar menerima ketentuan Illahi jika ketentuannya itu tidak menyenangkan diri, dan bersyukur jika dipinjamiNya nikmat, tetapi harus mencari tau apa nikmat yang diberikan Allah kepada kita jika kita tidak tahu apa nikmat yang diberikanNya maka itu bukanlah syukur melainkan sebuah keterpaksaan (Rahmat, 2017). Sedangkan Sufistik modern seperti Haji Abdul Malik Karim Abdullah (Hamka) menafsirkan Qana'ah sebagai menerima segala sesuatu dengan cukup, Hamka juga memetakan lima perkara yang terkandung dalam Qana'ah antara lain, menerima dengan rela akan apa yang ada, memohonkan kepada Allah Tambahan yang pantas, dan berusaha, menerima dengan sabar akan ketentuan Allah, bertawakal kepada Allah serta tidak tertarik oleh tipu daya dunia. Tafsir tersebut berdasar dari pengkajian sabda Rassulullah SAW. "Bukanlah kekayaan itu lantaran banyak harta, kekayaan ialah kekayaan jiwa” (Ulfah \& Istiyani, 2016)

Sifat Qana'ah merepresentasikan kepuasan terhadap apa yang dimiliki maupun dicapai, hal ini berkaitan dengan Qana'ah sebagai upaya dalam menjalani kehidupan yang baik dan sehat atau dalam kajian Islam disebut Hayattan Tayyibah (Ali, 2014). Qana'ah juga memiliki peran dalam mengatasi masalah sosial dan lingkungan (Ali, 2014). Sebagai seorang Muslim wajib hukumnya melaksanakan akhlak baik dalam berperilaku seharihari, sebab akhlak baik merupakan pijakan masyarakat muslim dalam beribadah, bermasyarakat serta dalam menghadapi segala bentuk problematika dan masalah. akhlak yang baik juga merupakan cerminan dari muslim yang memang menjalankan perintah agama atau dapat disebut memiliki kadar spiritualitas.

\section{METODE}

\section{Desain}

Penelitian ini menggunakan dua tahap Squential, yakni tahap pertama terdiri dari eksplorasi konstrak Qana'ah berbasis Indigenous dan tahap kedua adalah konstruksi skala Qana'ah dari hasil eksplorasi tahap pertama yang kemudian dilakukan penskalaan pada butir dengan proporsi liker 5 pilihan jawaban. Metode analisis yang digunakan dalam tahap pertama penelitian adalah analisis kualitatif, dengan teknik kategorisasi dengan tiga tahapan yakni coding kesamaan kata, kesamaan definisi dan analisa content Kalimat pada jawaban dari open ended questionnaire, sedangkan metode analisis pada tahap kedua menggunakan analisis kuantitatif yakni analisis reliabilitas dengan formulasi 
Alpha Cronbach untuk melihat koefisien reliabilitas, uji keselarasan fungsi ukur menggunakan item-total correlation dan anlisis faktor eksploratori menggunakan principal component analysis. Semua analisis statistika dalam penelitian ini menggunakan bantuan perangkat lunak SPSS 17 For Windows.

\section{Responden}

Subyek penelitian yang berpartisipasi adalah masyarakat lokal yang memiliki nilai-nilai kontekstual budaya Indonesia saat ini. Batasan sub-kultur tidak dikaji dalam penelitian ini, yang artinya subyek penelitian bisa dari budaya manapun, sedangkan batasan karakteristik subyek hanya dari agama (Islam) dan kewarganegaraan (Indonesia). Tujuan dilakukanya penyaringan karakteristik dalam penenlitian ini adalah untuk membatasi bias sampling yang mana dapat menyebabkan penyebaran kuisioner kepada responden yang tidak tepat. Subyek penelitian pada tahap pertama adalah masyarakat lokal di kota Malang dengan berbagai latar belakang pendidikan, meliputi SMP (N=91), SMA (N=135), Diploma (14), S1 (19). Pada tahap kedua melibatkan sebanyak 150 Subyek.

\section{HASIL}

\section{Tahap Pertama}

Tahap pertama dalam penelitian ini bertujuan untuk eksplorasi konstrak Qana'ah berbasis Spiritual Indigenous. Pada tahap pertama metode pengumpulan data yakni dengan menyebarkan survey open ended questionnaire dengan topik Qana'ah. Aitem open ended questionnaire berupa pertanyaan terbuka yakni "Menurut anda perilaku apa saja yang mencerminkan Qana'ah?”. Dari Jawaban subyek Kemudian dilakukan analisis kategorisasi berdasarkan similaritas respon dan jawaban serta kata kunci. Kategorisasi dilakukan sebanyak tiga tahap. Keseluruhan open ended questionnaire $(\mathrm{n}=259)$ memenuhi persyaratan administrasi (angket tidak kosong maupun rusak secara fisik). Kategorisasi 1 menghasilkan sebanyak 254 dari 259 angket yang dapat dikategorisasi, sisanya memiliki jawaban yang tidak dapat dikategorikan. Tahap kategorisasi kedua dan ketiga tetap menyisahkan 254 angket yang dapat dikategorisasi. hasil final kategorisasi jawaban subyek pada open ended questionnaire dapat dilihat pada tabel 1 (hal. 5).

Hasil final kategorisasi dari eksplorasi konstrak Qana'ah ditemukan empat aspek utama yang menyusun konstrak Qana'ah pada masyarakat lokal, yakni: 
Tabel 1. Hasil Kategorisasi Open Ended Questionaire

\begin{tabular}{ll}
\hline Kategorisasi & Jumlah \\
\hline Menerima apa adanya & 100 \\
Sabar dan Berserah & 87 \\
Selalu Bersyukur & 52 \\
Selalu Berusaha & 15 \\
\hline
\end{tabular}

a. Menerima apa adanya

Dalam menanggapi segala sesuatu yang terjadi senantiasa menerima dengan lapang dada dan ikhlas atas kehendak Allah SWT. menerima apa adanya yang dimaksud adalah dengan artian yang positif, bukan dengan artian menyerah sebelum berusaha melainkan menerima hasil yang diluar kemampuan usaha yang dilakukan.

b. Sabar dan Berserah

Dimaknai sebagai rasa sabar dalam menjalankan segala proses yang ingin dicapai, maupun sikap sabar dalam menjalani ujian yang dihadapi, adapun berserah dimaknai sebagai menyerahkan diri sepenuhnya kepada Allah SWT. atas segala keadaan yang djalani, berserah bukan hanya dimaknai sebagai menyerah melainkan tetap optimis terhadap pertolongan Allah SWT.

c. Selalu Bersyukur

Dimaknai sebagai wujud terimakasih kepada Allah SWT. atas segala nikmat yang diberikan maupun capaian yang diperoleh. Bersyukur dapat di aplikasikan dalam bentuk ucapan maupun perilaku. Seorang Muslim mempercayai apabila bersyukur atas segala nikmat maka Allah SWT. akan melipatgandakan Nikmat yang diberikan.

d. Selalu Berusaha

Dimaknai sebagai upaya dalam meraih sesuatu yang diinginkan maupun usaha dalam memecahkan segala bentuk persoalan yang terjadi. Dalam Ajaran Islam berusaha tercermin dalam sikap Ikhtiar manusia dalam memenuhi kebutuhan dalam hidupnya.

\section{Tahap Kedua}

Selanjutnya dilakukan konstruksi instrumen pengukuran psikologi dengan konstrak Qana'ah yang didapatkan dalam tahap pertama, berupa skala Qana'ah berbasis Spiritual Indigenous. Langkah-langkah yang dilakukan adalah sebagai berikut :

a. Identifikasi konstrak Qana'ah

Pada tahap pertama menemukan konstrak Qana'ah dari Open Ended Questionaire dan dianalisis secara kualitatif melalui kategorisasi. Dan dari hasil eksplorasi tersebut Qana'ah didefnisikan sebagai sifat maupun sifat (akhlak) yang 
terintegrasi dari sikap menerima apa adanya, sabar dan berserah, selalu bersyukur serta berusaha.

b. Operasionalisasi Indikator Perilaku

Dari temuan eksplorasi pada tahap pertama penelitian,memunculkan beberapa aspek yang menjadi acuan dalam operasionalisasi indikator perilaku, yakni : Menerima apa adanya, Sabar dan berserah, Selalu bersyukur serta Selalu berusaha.

c. Penskalaan dan penulisan skala

Penelitian ini mengkonstruksikan skala Qana'ah dengan jenis penskalaan Likert 5 pilihan jawaban, yakni : Sangat tidak setuju (STS), Tidak setuju (TS), Netral $(\mathrm{N})$, Setuju (S) dan Sangat Setuju (SS). Sesudah menentukan jenis penskalaan, selanjutnya membuat Blueprint skala Qana'ah.Jumlah butir dari skala Qana'ah direncanakan sebanyak 20 butir dengan spesifikasi setiap aspek memuat 5 butir. Blueprint skala Qana'ah dapat dilihat pada tabel 2 (lihat tabel 2).

Langkah selanjutnya adalah menyebarkan skala kepada 150 subyek dengan karakteristik yang sama dengan subyek tahap pertama yakni Agama (Islam) dan Kewarganegaraan (Indonesia). Subyek uji coba skala Qana'ah adalah masyarakat lokal yang berada di wilayah Kota Malang. Metode analisis ujicoba menggunakan uji reliabilitas dengan formulasi Alpha Cronbach dan juga menggunakan uji korelasi item-total untuk menyeleksi butir yang tidak selaras dengan fungsi ukur.

\section{Tabel 2. Blueprint Skala Qana'ah}

\begin{tabular}{lllll}
\hline No. & Aspek & Nomor Butir & $\begin{array}{l}\text { Jumlah } \\
\text { Butir }\end{array}$ & $\begin{array}{l}\text { Bobot } \\
(\%)\end{array}$ \\
\hline 1. & Menerima apa adanya & $1,2,3,4,5$ & 5 & 25 \\
2. & Sabar dan berserah & $6,7,8,9,10$ & 5 & 25 \\
3. & Selalu bersyukur & $11,12,13,14,15$ & 5 & 25 \\
4. & Selalu berusaha & $16,17,18,19,20$ & 5 & 25 \\
\hline Total & & 20 & 100 \\
\hline
\end{tabular}

Hasil analisis korelasi item-total pada setiap butir skala Qana'ah dengan total skor, dilakukan dengan tujuan penyisihan item yang kurang layak. Dengan menggunakan ketentuan diatas 0,30 untuk butir yang layak (Azwar, 2010). Sedangkan korelasi itemtotal dibawah 0,30, maka butir-butir tersebut disisihkan dalam skala Qana'ah. Sedangkan butir nomor $1,3,4,6,8,9,10,13,15,16,17,18$ dan 19 mendapatkan nilai koefisien korelasi item-total dari 0,339 sampai 0,693. Hasil Analisis reliabilitas dapat dilihat pada tabel 3. 
Tabel 3. Output Uji Reliabilitas

\begin{tabular}{ll}
\multicolumn{2}{c}{ Reliability Statistics } \\
\hline Cronbach's Alpha & N of Items \\
\hline .872 & 13 \\
\hline
\end{tabular}

Pada tabel 3 menunjukan bahwa nilai koefisien Alpha Cronbach sebesar 0,826 dimana dapat disimpulkan memiliki koefisien reliabilitas dalam taraf yang tinggi.Langkah selanjutnya adalah analisis faktor eksploratori (EFA), analisis EFA digunakan dalam penelitian ini untuk mengungkap muatan faktor pembentuk konstrak Qana'ah. Sebelum melakukan analisis faktor eksploratori, terlebih dahulu dilakukan analisis asumsi kelayakan jumlah sampel dengan menggunakan KMO and Bartlett's Test, output KMO and Bartlett's Test dapat dilihat pada tabel 4 di bawah.

Tabel 4. Output KMO and Bartlett's Test

KMO and Bartlett's Test

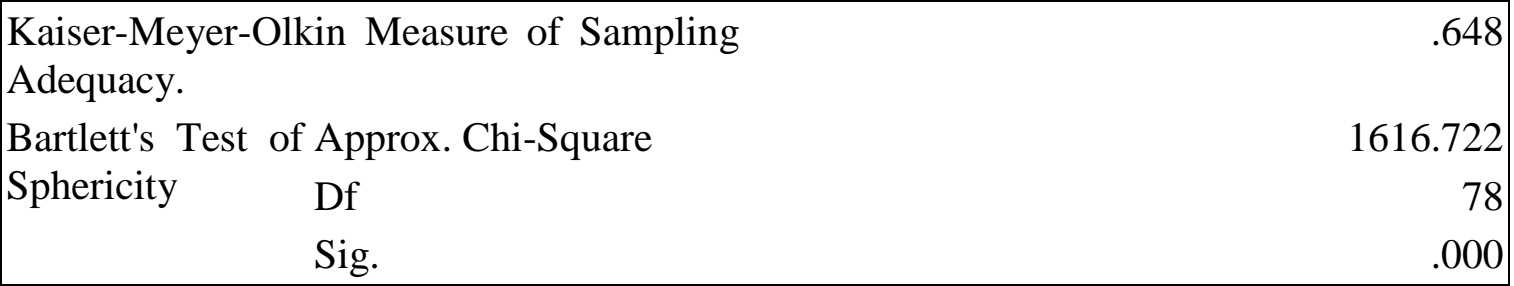

Pada tabel 4 didapatkan nilai $K M O$ sebesar 0,648 yang mana lebih besar dari 0,50, hal ini mengindikasikan bahwa asumsi dari jumlah sampel terpenuhi, Pada tabel 4 diatas juga didapatkan nilai Sig. Bartlett"s Test sebesar 0,000, yang mana lebih kecil dari 0,05 maka uji asumsi Bartlett"s Test juga terpenuhi. selanjutnya dilakukan analisis asumsi independensi faktor yang dianalisis menggunakan korelasi Anti-Image. Korelasi AntiImage mendapatkan nilai dari 0,550 samapai dengan 0,803 dimana nilai korelasi tersebut diatas 0,5, maka uji asumsi korelasi terpenuhi. Selanjutnya adalah ekstraksi faktor, Penelitian ini menggunakan metode ekstraksi faktor Principal Component Analysis $(P C A)$. PCA digunakan untuk melihat berapa banyak faktor yang membentuk konstrak Qana'ah. Hasil analisis pada tabel 5 (lihat tabel 5).

Dari tabel 5. dapat dilihat beberapa nilai initial eigenvalues, pada kolom total didapatkan nilai 5,551 untuk komponen 1 dan 2,495 untuk komponen 2 serta komponen 3 sebesar 1,257. Sedangkan komponen 4 mendapatkan nilai dibawah 1. Maka dapat disimpulkan, faktor yang membentuk konstrak Qana'ah berjumlah 3 Faktor. 
Tabel 5. Analisis Ekstraksi Faktor

\begin{tabular}{lrrrrrr}
\hline & \multicolumn{2}{c}{$\begin{array}{c}c \\
\text { Initial Eigenvalues }\end{array}$} & \multicolumn{2}{c}{ Rotation Sums of Squared Loadings } \\
Component Total & $\begin{array}{c}\text { Variance } \\
\text { Cumulative }\end{array}$ & \multicolumn{2}{c}{ \% } & Total \% & of Variance Cumulative \% \\
1 & 5.551 & 42.704 & 42.704 & 3.521 & 27.081 & 27.081 \\
2 & 2.495 & 19.190 & 61.893 & 3.420 & 26.306 & 53.388 \\
3 & 1.257 & 9.667 & 71.561 & 2.363 & 18.173 & 71.561 \\
4 & .899 & 6.917 & 78.477 & &
\end{tabular}

${ }^{\mathrm{a}}$ Extraction Method: Principal Component Analysis.

Tahap terakhir analisis faktor eksploraori dalam penelitian ini adalah menentukan butir yang membentuk aspek dari skala Qana'ah melalui analisis Principal Component Analysis, dengan metode rotasi varimax. Hasil analisis dapat dilihat pada tabel 6 .

Tabel 6. Matriks Rotasi Komponen

\begin{tabular}{l|ccc}
\hline Item & \multicolumn{3}{c}{ Muatan Faktor } \\
\cline { 2 - 4 } & $\mathbf{1}$ & $\mathbf{2}$ & $\mathbf{3}$ \\
\hline QA1 & .858 & & \\
QA3 & .876 & & \\
QA4 & .650 & .795 & \\
QA6 & & .831 & \\
QA8 & & .666 & \\
QA9 & & .727 & .575 \\
QA10 & & & .535 \\
QA13 & .720 & & .834 \\
QA15 & .663 & & .821 \\
QA16 & & & \\
QA17 & & & \\
QA18 & & & \\
QA19 & & & \\
\hline
\end{tabular}

Extraction Method: Principal Component Analysis.

Rotation Method: Varimax with Kaiser Normalization.

Pada tabel 6. diatas dapat dilihat bahwa butir nomor 1, 3, 4, 10, 13 dan 15 memiliki korelasi diatas 0,50 dengan faktor 1 , yang secara berurutan dari 0,650 sampai dengan 0,876 hal ini menunjukan bahwa butir-butir tersebut merupakan butir yang membentuk 
faktor 1, sedangkan butir nomor 6,8 dan 9 mendapatkan nilai korelasi secara berurutan dengan faktor 2 dari 0,666 sampai dengan 0,831, maka butir-butir tersebut adalah butir yang membentuk faktor 2 serta butir 16, 17,18 dan 19 mendapatkan nilai korelasi dengan faktor 3 secara berurutan dari 0,535 sampai dengan 0,834 yang mana dapat disimpulkan merupakan butir pembentuk faktor 3 .

\section{DISKUSI}

Penelitian yang dilakukan secara holistik bertujuan untuk mengembangkan skala Qana'ah berbasis spiritual indigenous. Penelitian tahap pertama menggunakan pendekatan kualitatif, yakni dengan metode analisis kategorisasi jawaban Open Ended Questionaire, hasil penelitian tahap pertama menemukan 4 aspek pembentuk konstrak Qana'ah, antara lain : menerima apa adanya, sabar dan berserah, selalu bersyukur dan selalu berusaha. Hasil eksplorasi tahap pertama mengindikasikan bahwa masyarakat lokal memandang sifat Qana'ah lebih pada penerapan perilaku keseharian yang mencerminkan akhlak terpuji yang diajarkan pada agama Islam. Sifat menerima apa adanya dapat diartikan sebagai pandangan akan segala sesuatu yang terjadi adalah hal baik yang diberikan oleh Allah SWT. kepada hambanya, hal ini juga merupakan cerminan dari perilaku lapang dada. Menerima apa adanya juga memiliki esensi dari perasaan cukup akan segala sesuatu yang diberikan Allah SWT. Merasa cukup atas apa yang menjadi hak miliknya atau capaian yang diperoleh, juga bisa dilihat dengan kesederhanaan maupun kecukupan dalam memperlakukan materi (Noorhayati, 2016).

Sedangkan aspek kedua yang ditemukan adalah sabar dan berserah. Sabar secara definisi dapat diartikan sebagai sifat menahan emosi dan keinginan atau dapat dikatakan kemampuan mengendalikan diri, tidak mengeluh akan sesuatu serta bertahan dalam situasi sulit. Setidaknya ada 5 aspek yang membentuk sabar, yakni pengendalian diri, ketahanan, persistensi, menerima kenyataan, dan tetap tenang (Subandi, 2011). Sedangkan berserah memiliki definisi sebagai sikap mempercayakan segala sesuatu kepada Allah. SWT. namun tetap berusaha sebagai upaya dalam menyelesaikan segala problematika. Dari temuan eksplorasi tahap pertama masyarakat lokal lebih memaknai sabar dan berserah merupakan sebuah sikap yang saling ter-konteks satu dengan lainya atau dapat dikatakan bahwa sikap sabar haruslah di iringi dengan sikap berserah kepada Allah SWT. Dalam menjalani problematika kehidupan, ajaran agama Islam mengajarkan beberapa strategi dalam mengelola problematika yang menyebabkan stres yakni ikhlas, sabar dan shalat, bersyukur dan berserah diri, doa dan dzikir, hal ini juga dijumpai dalam psikologi yakni relaksasi, berpikir positif, dan mengatur waktu (Susatyo, 2010). Dalam ajaran agama Islam, kedua sikap ini juga sangat erat kaitanya dalam membentuk akhlak baik (Mahmudah).

Selanjutnya aspek yang ditemukan dalam membentuk Qana'ah adalah selalu bersyukur. Bersyukur secara sederhana dapat diartikan sebagai sikap berterimakasih atas segala nikmat yang diberikan oleh Allah SWT. Masyarakat lokal memaknai akhlak Qana'ah mengandung unsur sikap selalu bersyukur, sebab dalam penerapanya bersyukur merupakan sebuah sikap menghargai semua karunia, dengan bersyukur maka kehidupan akan menjadi lebih bermakna dan tanpa menambah beban keinginan yang terkadang 
ambisius. Beberapa aspek bersyukur adalah memiliki rasa apresiasi, perasaan positif terhadap kehidupan yang dimiliki dan kecenderungan untuk bertindak positif sebagai bentuk dari perasaan positif dan apresiasi yang dimiliki (Fitzgerald, 1998; Watskin 2003; Ratih, 2011).

Aspek terakhir yang ditemukan adalah selalu berusaha, selalu berusaha dapat dimaknai sebagai upaya yang terus menerus dilakukan dalam mencapai sesuatu. Seorang muslim yang mencerminkan perilaku berusaha tak hanya berdoa dan meminta saja kepada Allah SWT. melainkan juga melakukan usaha, maka menurut pandangan masyarakat lokal dalam menerapkan akhlak Qana'ah dapat dilakukan melalui perilaku selalu berusaha. kajian psikologi memandang individu dalam berusaha dapat dilihat dari sejauh mana individu memiliki tingkatan daya juang atau disebut Adversity Quotient yakni kemampuan berusaha dalam menghadapi kesulitan (Stoltz, 2010).

Pada tahap kedua dalam penelitian ini bertujuan untuk mengembangkan konstrak Qana'ah kedalam skala psikologi. Langkah pertama dalam konstruksi skala adalah dengan membuat blueprint, rencana awal untuk jumlah butir pada skala Qana'ah sebanyak 20 butir. Namun dari 20 butir yang sudah dibuat terdapat butir-butir yang disishkan karena tidak sesuai dengan ketentuan nilai minimal koefisien item-total, yakni butir 2, 5, 7, 11, 12, 14 dan 20. Sedangkan butir 1, 3, 4, 6, 8, 9, 10, 13, 15, 16, 17, 18 dan19 adalah butir yang memenuhi kriteria korelasi item-total yakni diatas 0,30. Hasil analisis reliabilitas skala Qana'ah memiliki nilai alpha cronbach sebesar 0,872 yang merupakan kategori tinggi. Pengembangan alat ukur atribut psikologi yang lebih komprehensif dapat dilanjutkan dengan uji validitas skala yang mungkin dapat dilakukan berkelanjutan, dalam penelitian ini uji validitas skala hanya pada paparan content, bukan pada paparan identifikasi psikometris yang lebih lengkap.

Analisis faktor eksploratori (EFA) digunakan dalam penelitian untuk mengeksplorasi muatan faktor dari butir yang membentuk aspek-aspek pada skala Qana'ah. Metode yang digunakan dalam ekstraksi faktor adalah Principal Component Analysis (PCA). Hasil ekstraksi faktor didapatkan 3 faktor pembentuk konstrak Qana'ah. Selanjutnya digunakan analisis Rotated Component Matrix, untuk melihat muatan butir yang membentuk faktor atau aspek pada skala Qana'ah. Dari analisis rotasi komponen yang dilakukan butir nomor 1, 3 dan 4 merupakan komponen yang membentuk aspek "menerima apa adanya", hal ini sesuai dengan rencana blueprint, namun ada tambahan butir yang membentuk aspek 1 skala Qana'ah yakni butir 13 dan 16 dimana sebelumnya kedua butir tersebut pada susunan blueprint, merupakan butir pada aspek "selalu bersyukur", hal ini menunjukan bahwa aspek "menerima apa adanya" dan "selalu bersyukur" merupakan aspek yang memiliki kesamaan atau dapat dikatakan aspek yang sama. Ini mengindikasikan bahwa pandangan masyarakat lokal terhadap sikap menerima apa adanya dan bersyukur memiliki makna yang relatif sama atau bisa juga dari respon subyek terhadap pertanyaan maupun pernyataan pada butir skala Qana'ah yang sudah disusun, pada aspek menerima apa adanaya dan selalu bersyukur memiliki respon yang cenderung mirip (dilihat dari jawaban skala), dibuktikan dengan nilai korelasi yang di dapatkan pada butir-butir yang membentuk faktor satu, yakni dari 0,650 sampai dengan 0,876 yang dapat dikatakan korelasi dalam kategori sedang ke tinggi. Penaman untuk faktor satu dilakukan dengan menggabungkan aspek rencana blueprint yang sudah dibuat 
dimana aspek menerima apa adanya dan selalu bersyukur terbentuk kedalam faktor satu, penamaan untuk fakor satu adalah aspek "Menerima apa adanya dan Bersyukur".

Untuk Aspek 2 yakni "sabar dan berserah" butir pembentuk aspek adalah butir nomor 6, 8 dan 9, dimana sesuai dengan rencana blueprint yang telah dibuat, maka dapat disimpulkan bahwa butir-butir pembentuk faktor atau aspek 2 menggunakan nama aspek asli pada blueprint, yakni aspek "Sabar dan Berserah". Sedangkan untuk butir 16, 17, 18 dan 19 merupakan butir pembentuk aspek 3 yakni "selalu berusaha" hal ini linier dengan blueprint yang sudah dibuat, sehingga penamaan untuk faktor 3 juga sama dengan blueprint, yakni aspek "Selalu Berusaha".

\section{SIMPULAN DAN IMPLIKASI}

Dari hasil penelitian dapat disimpulkan bahwa persepsi masyarakat lokal terhadap Qana'ah secara holistik sama dengan yang di ajarkan Agama Islam, dimana Qana'ah memiliki atribut merasa cukup, berusaha dengan segala kemampuan dan bersserah kepada ketentuan Allah SWT. Sikap merasa cukup dapat dilihat dari aspek temuan pada konstrak Qana'ah yang pertama, dimana menerima apa adanya adalah bentukan dari sikap merasa cukup atas segala nikmat yang diberikan Allah SWT. hal ini juga direpresentasikan dalam perilaku selalu bersyukur. Sedangkan aspek dua dalam temuan penelitian ini adalah aspek sabar dan berserah, dimana aspek ini merupakan salah satu indikator dari akhlak Qana'ah. Adapun Aspek 3 yakni Selalu Berusaha juga merupakan cerminan pribadi yang memiliki akhlak Qana'ah.

Implikasi dari penelitian yang dilakukan, khususnya pada masyarakat muslim adalah bahwa ajaran Agama Islam secara khusus, lengkap dan lebih dulu mengajarkan tatanan perilaku yang baik dalam ber-kehidupan, Ajaran Islam memberikan tuntunan kepada kaum muslim untuk selalu bersikap dan berperilaku baik kepada sesama manusia maupun makhluk ciptaanNYA. Penelitian ini hanyalah secuil pengetahuan dari ajaran Islam, dimana masih banyak ajaraan Agama Islam yang membahas mengenai manusia dalam berperilaku. Melalui menerapkan akhlak Qana'ah kaum muslim dapat menjalani aktivitas kehidupan lebih baik dan juga merupakan terapan dalam menjalankan perintah Allah SWT., hal ini juga merupakan terapan dalam sikap spiritualitas masyarakat muslim.

Bagi ilmu pengetahuan maupun penelitian khususnya ilmu Psikologi di Indonesia melalui penelitian ini adalah, dapat dilanjutkannya pengembangan instrumen atribut psikologi berbasis Indigenous. Indonesia yang merupakan negara dengan suku budaya yang beragam, kaya akan objek kajian Indigenous Psikologi, sehingga diharapkan banyak peneliti yang memulai penelitian psikologi dari budaya asli masyarakat Indonesia. 


\section{REFERENSI}

Ali, M. F. (2014). Contentment (Qana'ah) and Its Role in Curbing Social and Environmental Problems. Islam and Civilisational Renewal (ICR); Vol. 5, 3. 430445

Amir, Y., \& Lesmawati, D. R. (2017). Teligiusitasdan Spiritualitas konsep yang sama atau berbeda?. Jurnal Ilmiah Penelitian Psikologi: Kajian Empiris \& Non-Empiris, Vol. 2, 2. 67-73. https://doi.org/10.22236/JIPP-21

Anggoro, W. J., \& Widhiarso, W. (2010). Konstruksi dan Identifikasi Properti Psikometris Instrumen Pengukuran Kebahagiaan Berbasis Pendekatan Indigenous Psychology: Studi Multitrait-Multimethod. Jurnal Psikologi.Vol. 37, 2. 176-188.

Azwar, S. (2010). Reliabilitas dan Validitas. Yogyakarta: Pustaka Pelajar.

Badan Pusat Statistik. (2010). Sensus Penduduk 2010 - Penduduk Menurut Wilayah dan Agama yang Dianut. Jakarta : Badan Pusat Statistik

Dy-Liacco, G. S., Piedmont, R. L., Murray-Swank, N. A., Rodgerson, T. E., \& Sherman, M. F. (2009). Spirituality and Religiosity as Cross-Cultural Aspects of Human Experience. Psychology of Religion and Spirituality. Vol.1, 1. 35-52 https://doi.org/10.1037/a0014937

Faturochman, Wenty, M. M., \& Tabah, A. N. (2017). Memahami dan Mengembangkan Indigenous Psychology. Yogyakarta: Pustaka Pelajar.

Fitzgerald, P. (1998). Gratitude and Justice. Ethics. Vol. 109, 1. 119-153. https://doi.org/10.1086/233876

Hill, J. (2000). A rationale for the integration of spirituality into community psychology. Journal of Community Psychology. Vol. 28, 2. 139-149. https://doi.org/10.1002/(SICI)1520-6629(200003)28:2<139::AID JCOP3>3.0.CO;2-X

Kim, U., Yang, K., \& Hwang, K.-K. (2006). Contributions to Indigenous and Cultural Psychology: Understanding People in Context. In Indigenous and cultural psychology: Understanding people in context.

Lubis, A. S. (2012). Konsep Akhlak dalam Pemikiran al-Ghazali. Jurnal Hikmah Vol. VI, No. 01, Vol.4, 1. 58-67

http://repo.iain-padangsidimpuan.ac.id/201/1/Agus\%20Salim\%20Lubis1.pdf.

Mujib, A. (2012). Konsep Pendidikan Karakter Berbasis Psikologi Islam. Prosiding Seminar Nasional Psikologi Islami.

https://publikasiilmiah.ums.ac.id/bitstream/handle/11617/1746/A1.\%20MujibUIN\%20\%28fixed\%29.pdf?sequence=1\&isAllowed=y.

Muttaqin, A. (2012). Islam and the changing meaning of spiritualitas and spiritual in contemporary indonesia. Journal of Islamic Studies, Vol. 50, 23. 25-56 http://www.aljamiah.or.id/index.php/AJIS/article/view/135. 
Noorhayati, M. (2016). Konsep Qonaah dalam Mewujudkan Keluarga Sakinah Mawaddah dan Rahmah. Jurnal Bimbingan Konseling Islam.Vol. 7, 2. 59-76 http://journal.stainkudus.ac.id/index.php/konseling/article/download/S.\%20Mahmu dah\%20Noor\%20Hayati\%20-\%20Farhan/pdf.

Rahmat, Z. (2017). Penafsiran Abdul Qadir Al Jailani tentang Qana'ah: Analisis terhadap Al Jailani. Naskah Publikasi. Bandung : UIN Sunan Gunung Djati. http://digilib.uinsgd.ac.id/8862

Samovar, Larry, Richard Porter, and E. M. (2009). Communication between Cultures. Cultures (Terjemahan). Yogyakarta : Salemba Humanika

Sawatzky, R., Ratner, P. A., \& Chiu, L. (2005). A meta-analysis of the relationship between spirituality and quality of life. Social Indicators Research. Vol. 72, 2. 153-188. https://doi.org/10.1007/s11205-004-5577-x

Stoltz, P. G. (2010). Adversity Quotient Work: Finding Your Hidden Capacity For Getting Things Done. New York: Harper Collins.

Subandi. (2011). Sabar: Sebuah Konsep Psikologi. Jurnal Psikologi. Vol. 38, 2. 215-227 https://jurnal.ugm.ac.id/jpsi/article/view/7654/5934

Susatyo, Y. (2010). Mengelola Stress dalam perspektif Islam dan Psikologi . Jurnal Psycho Idea Universitas Muhammadiyah Purwokerto, Vol 8, No. 2. 14-26. https://doi.org/10.30595/psychoidea.v8i2.231

Ulfah, N. M., \& Istiyani, D. (2016). Etika Dalam Kehidupan Modern : Studi Pemikiran Sufistik Hamka. Esoterik: Jurnal Akhlak Dan Tasawuf. Vol. 2, 1. 95-109 Journal.stainkudus.ac.id/index.php/esoterik/article/download/1896/pdf

VandenBos, G. R. (2013). APA Dictionary Of Psychology 2nd Edition. Washington, D.C : American Psychological Association.

Veenhoven, R. (2012). Cross-national differencies in happiness: Cultural measurment bias or effect of culture?. International Journal of Well-Being. Vol. 2, 4. 333-353 https://doi.org/10.5502/ijw.v2.i4.4

Zaini, A. (2016). Pemikiran Tasawuf Imam Al-Ghazali. Akhlak Dan Tasawuf. Vol. 2, 1. 146-159. https://doi.org/10.21043/esoterik.v2i1.1902 


\title{
KEPRIBADIAN EKSTRAVERSI DAN KESEPIAN PADA REMAJA PANTI ASUHAN
}

\author{
Erwin Hogi ${ }^{1}$, Achmad Irvan Dwi Putra ${ }^{2}$ \\ ${ }^{1,2}$ Fakultas Psikologi Universitas Prima Indonesia \\ e-mail: ${ }^{1}$ hogi_erwin@yahoo.com
}

\begin{abstract}
Abstrak. Penelitian ini bertujuan untuk mengetahui hubungan kepribadian ekstraversi dengan kesepian. Hipotesis yang diajukan adalah terdapat hubungan negatif antara kepribadian ekstraversi dengan kesepian, dengan asumsi semakin tinggi kepribadian ekstraversi, maka semakin rendah kesepian begitu pula sebaliknya. Subjek penelitian yang digunakan dalam penelitian ini adalah remaja yang tinggal di Panti Asuhan Al Jam'iyatul Washliyah Pulo Brayan Medan sebanyak 123 orang yang dipilih dengan metode purposive sampling. Data diperoleh dari skala untuk mengukur kepribadian ekstraversi dan kesepian. Analisis data yang digunakan adalah menggunakan Pearson Product Moment Correlation melalui bantuan program SPSS 19.00 for Windows. Hasil analisis data menunjukkan koefisien korelasi sebesar -0.731 ( $\mathrm{p}<0.05)$ dan menunjukkan terdapat hubungan negatif antara kepribadian ekstraversi dengan kesepian. Hasil penelitian ini menunjukkan bahwa sumbangan yang diberikan kepribadian ekstraversi terhadap kesepian adalah sebesar 53.4 persen, selebihnya 46.6 persen dipengaruhi oleh faktor lain yang tidak diteliti. Dari hasil penelitian ini dapat ditarik kesimpulan bahwa hipotesis penelitian dapat diterima.
\end{abstract}

Kata kunci: kepribadian ekstraversi, kesepian

\begin{abstract}
This study aims to find relationship between extraversion personality and loneliness. The hypothesis of this study states that there is a negative relationship between extraversion personality and loneliness, assuming that the higher the extraversion personality is, the lower the loneliness will be and conversely. The subjects of this study were adolescents orphanage in Al Jam'iyatul Washliyah Medan consisting of 123 subjects selected by using purposive sampling method. Data were obtained from a scale to measure extraversion personality and loneliness. Analysis of the data used is Pearson Product Moment Correlation with SPSS 19.00 for Windows program. The results of data analysis showed a correlation coefficient of $-0.731(p<0.05)$ and showed that there is a negative relationship between extraversion personality and loneliness. The results of this study indicate that the contributions made by extraversion personality to the loneliness was 53.4 percent and the remaining 46.6 percent is influenced by other factors that are not examined. From these results it is concluded that the hypothesis is acceptable.
\end{abstract}

Keywords: extraversion personality, loneliness 
Masa remaja merupakan masa transisi antara masa anak-anak menuju masa dewasa. Masa di mana individu meninggalkan masa anak-anaknya memasuki masa dewasa (Batubara, dalam Utami, Ahmad, \& Ifdil, 2017). Remaja dituntut untuk menguasai tugas perkembangannya, salah satunya perkembangan sosial. Pada periode ini, individu tidak hanya dituntut untuk bersosialisasi dengan keluarga, namun juga dengan masyarakat sehingga individu dapat berbaur dan menyesuaikan diri dengan norma yang berlaku di masyarakat (Prayitno, dalam Utami, dkk., 2017). Pada masa transisi inilah, emosi remaja terkadang menjadi kurang stabil, sehingga tidak jarang ditemui remaja yang melakukan perilaku menyimpang dan negatif jika terjebak dalam lingkungan pergaulan yang salah. Remaja yang mampu beradaptasi tentu akan memiliki banyak relasi dengan teman sebayanya sedangkan untuk remaja yang tidak mampu menyesuaikan diri akan merasa terpisah dengan lingkungannya, merasa hampa, dan juga merasa kosong. Ketidakmampuan dalam memenuhi tugas perkembangan ini menyebabkan remaja akan merasa dikucilkan, terasing, bahkan merasa kesepian.

Perasaan hampa dan kosong dapat mengarah pada perasaan kesepian (Johnson, 2014). Kesepian merupakan fenomena umum yang sering terjadi dalam kehidupan manusia. Kesepian dapat berasal dari berbagai faktor di antaranya genetik, kurangnya pengalaman sosial, dan gaya pendekatan dengan teman sebaya yang salah (Baron \& Branscombe, 2012).

Perasaan kesepian dalam jangka waktu lama mengakibatkan seseorang melakukan perilaku-perilaku yang menyimpang seperti konsumsi alkohol dan obat-obatan terlarang. Kesepian juga menjadi salah satu faktor seseorang melakukan bunuh diri (Azizog lu; DiTommaso; McWhirter, dalam Cecen, 2007). Berdasarkan studi yang pernah dilakukan, kesepian lebih banyak dialami oleh remaja dibandingkan orang dewasa (Heinrich \& Gullone, dalam Myers, 2012).

Fenomena kesepian telah banyak diteliti pada berbagai macam subjek, baik itu pada anak-anak, remaja, orang dewasa, mahasiswa, orang dengan lanjut usia, orang tua tunggal, perantau, maupun anak penghuni panti asuhan. Secara khusus, pada anak yang tinggal di panti asuhan memiliki peluang lebih besar untuk mengalami perasaan kesepian. Pada umumnya, anak-anak yang tinggal di panti asuhan adalah anak-anak yang memiliki keterbatasan ekonomi, telah kehilangan salah satu ataupun kedua orang tuanya, ataupun lainnya.

Hal tersebut sesuai dengan hasil survei awal yang peneliti lakukan di Panti Asuhan Al Jam'iyatul Washliyah Pulo Brayan Medan. Setelah dilakukan observasi dan wawancara pada para anak yang tinggal di panti asuhan tersebut, khususnya para remaja, mereka mengaku sering kali merasa asing dengan panti asuhan. Beberapa dari mereka yang telah tinggal di panti mengaku sering merasa tidak diterima dengan ramah oleh anak lainnya sehingga membuat mereka teringat kembali dengan keadaan rumah dan orang tuanya dulu. Mereka mengatakan setiap anak meskipun telah dewasa, pasti tidak ingin tinggal terpisah dari orang tuanya. Namun karena alasan keterbatasan kemampuan ekonomi orang tuanya, mereka pun terpaksa hidup terpisah dan tinggal di panti asuhan. Hal ini sering kali menyebabkan mereka merasa kesepian meskipun hidup bersama dengan 
banyak anak asuh. Hasil wawancara peneliti diperkuat dengan observasi yang didapatkan di lapangan ketika peneliti datang. Beberapa remaja terlihat lebih memilih menyendiri dibanding berbaur dengan anak-anak lainnya. Setelah peneliti wawancarai, subjek mengaku sedang ingin menyendiri dan tidak ada teman yang memiliki niat untuk menjalin komunikasi dengannya karena ia baru tinggal selama beberapa bulan di panti asuhan tersebut.

Kesepian merupakan pengalaman yang tidak menyenangkan saat individu merasakan perbedaan antara pola jaringan sosial mereka yang diinginkan dan terpenuhi. Definisi ini menganggap kesepian sebagai pengalaman negatif subjektif dan pengalaman yang menyebabkan frustrasi yang terkait dengan persepsi ketidakcocokan mengenai domain hubungan sosial (Peplau \& Perlman, dalam Vanhalst, Goosens, Luyckx, Scholte, \& Engels, 2013). Kesepian dapat menyebabkan seseorang tidak mau membentuk hubungan interpersonal dan kesulitan dalam membangun hubungan sosial dengan orang lain (Arnett, dalam Nayyar \& Singh, 2011). Kesepian juga dapat didefinisikan sebagai keadaan dimana terdapat kekurangan antara tingkat keterlibatan sosial, keinginan untuk menghabiskan waktu sendirian, dan isolasi sosial yang mengacu pada tingkat integrasi individu dan kelompok ke dalam lingkungan sosial yang lebih luas (Victor, Sasha, \& John, 2009).

Kesepian dapat dihubungkan dengan dan juga berpotensi dipengaruhi oleh trait kepribadian, shyness, dan kepribadian ekstraversi (Uruk \& Demir, dalam Bevinn, 2011). Pendapat tersebut juga didukung oleh Hawkley (dalam Riva \& Eck, 2016) yang menyatakan bahwa kepribadian ekstraversi dapat memengaruhi tingkat kesepian seseorang. Semakin tinggi kepribadian ekstraversi yang dimiliki seseorang, maka tingkat kesepian akan semakin rendah. Sehingga, kepribadian ekstraversi berkorelasi negatif dengan kesepian, yang berarti rendahnya kepribadian ekstraversi juga dapat berdampak pada tingginya perasaan kesepian.

Kepribadian ekstraversi adalah himpunan bagian dari sifat dengan model yang berbeda, yang di dalamnya mencakup sifat-sifat suka bersosialisasi, suka mencari sensasi, emosi positif, dan optimisme. Ekstraversi dapat didefinisikan dalam pengertian sempit dan pengertian yang luas. Dalam pengertian sempit, ekstraversi adalah individu yang senang membangun hubungan sosial dengan orang lain. Dalam definisi yang luas, ekstraversi dapat mencakup banyak komponen perilaku yang berbeda-beda seperti ketegasan, kehangatan, emosi positif, serta senang melakukan aktivitas (Depue \& Collins, dalam Weiner, 2003). Kepribadian ekstraversi merupakan sikap yang menjelaskan aliran psikis ke arah luar sehingga orang yang bersangkutan akan memiliki orientasi objektif dan menjauh dari subjektif (Jung, dalam Sarinah, 2017).

Kesepian dapat dirasakan setiap manusia pada berbagai usia tahap perkembangan. Pada salah satu penelitian terdahulu yang dilakukan terhadap 100 mahasiswa-mahasiswi Universitas Panjab, Chandigarh ditemukan hasil bahwa kepribadian ekstraversi berkorelasi negatif dengan kesepian. Dimana semakin tinggi kepribadian ekstraversi maka semakin rendah kesepian yang dirasakan mahasiswa-mahasiswi, dan sebaliknya 
semakin rendah kepribadian ekstraversi, maka semakin tinggi kesepian yang dirasakan oleh mahasiswa-mahasiswi tersebut (Nayyar \& Singh, 2011).

Peneliti tertarik untuk mengaitkan kepribadian ekstraversi dengan kesepian pada remaja yang tinggal menetap di panti asuhan. Kesepian sering kali dirasakan oleh remaja yang tinggal di panti asuhan karena mereka telah tinggal terpisah dari orang tuanya ataupun karena telah kehilangan orang tuanya. Lingkungan panti asuhan yang memiliki peraturan-peraturan yang harus ditaati menyebabkan lingkungan sosial remaja panti pun lebih terbatas. Sehingga, perasaan kesepian ini sangat minim untuk diminimalisir dengan cara menjalin hubungan pertemanan dengan orang-orang baru yang berada di luar panti.

Penelitian terdahulu oleh Saklofske, dkk., (1986) dalam penelitian yang melibatkan 101 mahasiswa-mahasiswi Universitas Canadian telah menemukan bahwa kesepian berkorelasi negatif dengan kepribadian ekstraversi. Orang-orang yang merasakan kesepian memiliki kontak interpersonal dan interaksi dengan orang lain yang lebih sedikit, juga akibat dari dukungan jaringan sosial yang kurang luas. Berbagai studi yang telah dilakukan menunjukkan orang yang kesepian memiliki kepribadian ekstraversi yang rendah.

Berdasarkan uraian-uraian sebelumnya, maka peneliti tertarik untuk meneliti hubungan antara kepribadian ekstraversi dengan kesepian pada remaja yang tinggal di Panti Asuhan Al Jam'iyatul Washliyah Pulo Brayan di Kota Medan. Adapun yang membedakan penelitian ini dengan penelitian terdahulu adalah karakteristik subjek dalam penelitian yang meliputi remaja yang tinggal menetap di panti asuhan, berusia 13-16 tahun, dan telah kehilangan salah satu ataupun kedua orang tuanya (yatim/piatu/yatim-piatu) guna mendapatkan gambaran kesepian yang lebih utuh pada remaja yang telah kehilangan orang tuanya. Tujuan dari penelitian ini untuk mengetahui hubungan antara kepribadian ekstraversi dengan kesepian. Manfaat praktis yang diharapkan dari penelitian ini jika hipotesis diterima adalah pihak pengurus, pengawas, dan pimpinan panti asuhan agar dapat mengadakan sharing group dengan semua anak asuh agar mengantisipasi munculnya perasaan kesepian pada anak asuh. Hipotesis yang diajukan dalam penelitian ini adalah terdapat hubungan negatif dan signifikan antara kepribadian ekstraversi dengan kesepian. Dengan asumsi semakin tinggi kepribadian ekstraversi maka semakin rendah kesepian subjek penelitian demikian pula sebaliknya, semakin rendah kepribadian ekstraversi pada subjek maka semakin tinggi kesepian yang dirasakannya.

\section{METODE}

Penelitian ini menggunakan desain penelitian kuantitatif dengan teknik analisis data korelasional. Penelitian korelasional sebagai teknik pengelolaan data dengan cara mengorelasikan atau menghubungkan dua data variabel atau lebih untuk mengetahui tingkat keeratan hubungan (Siswanto, Susila, \& Suyanto, 2017). Dalam penelitian ini menggunakan teknik pengujian korelasi Pearson Product Moment untuk melihat hubungan variabel bebas dengan variabel terikat. 
Populasi dalam penelitian ini sebanyak 315 anak yang tinggal di Panti Asuhan Al Jam'iyatul Washliyah Pulo Brayan Medan. Adapun alasan dipilihnya remaja yang tinggal di panti asuhan guna mengontrol variabel kesepian pada remaja yang telah kehilangan salah satu ataupun kedua orang tuanya dan tinggal menetap di panti asuhan. Penelitian ini melibatkan 123 remaja Panti Asuhan Al Jam'iyatul Washliyah Pulo Brayan yang dipilih dengan teknik purposive sampling dengan kriteria subjek berusia 13-16 tahun, anak yatim/piatu/yatim-piatu, dan remaja yang tinggal menetap di panti asuhan.

Alat pengumpul data dalam penelitian ini menggunakan skala pengukuran untuk mengukur kepribadian ekstraversi dan kesepian. Skala Kepribadian Ekstraversi peneliti kembangkan berdasarkan aspek-aspek ekstraversi yang dikemukakan oleh Depue dan Collins (dalam Weiner, 2003) yang meliputi aspek sociability, aspek agency, aspek activation, aspek impulsive-sensation seeking, dan aspek positive emotions. Total aitem untuk skala kepribadian ekstraversi sebanyak 40 aitem yang terdiri dari 8 aitem untuk aspek sociability yang terbagi menjadi 5 aitem favourable dan 3 aitem unfavourable, aspek agency terdiri dari 9 aitem yang terbagi menjadi 5 aitem favourable dan 4 aitem unfavourable, aspek activation terdiri dari 7 aitem yang terbagi menjadi 4 aitem favourable dan 3 aitem unfavourable, aspek impulsive-sensation seeking terdiri dari 7 aitem yang terbagi menjadi 4 aitem favourable dan 3 aitem unfavourable dan aspek positive emotions yang terdiri dari 9 aitem yang terbagi menjadi 4 aitem favourable dan 5 aitem unfavourable. Skala Kesepian peneliti kembangkan berdasarkan aspek-aspek kesepian yang dipaparkan oleh Weiss (dalam Margalit, 2010) yang meliputi aspek kesepian emosional dan aspek kesepian sosial. Total aitem untuk skala kesepian sebanyak 40 aitem yang terdiri dari 20 aitem untuk aspek kesepian emosional yang terbagi menjadi 10 aitem favourable dan 10 aitem unfavourable. Sedangkan, untuk aspek kesepian sosial terdiri dari 20 aitem yang terbagi menjadi 10 aitem favourable dan 10 aitem unfavourable.

Sebelum pengambilan data penelitian, peneliti melaksanakan try out terlebih dahulu terhadap 72 subjek remaja yang sesuai dengan karakteristik yang ditetapkan pada subjek penelitian di Panti Asuhan Al Jam'iyatul Washliyah Jalan Ismailiyah No. 82 di Kota Medan. Setelah dilakukan try out, hasil uji coba skala dijelaskan di bawah ini.

Hasil uji validitas terhadap Skala Kepribadian Ekstraversi ini menunjukkan nilai $\mathrm{r}_{i x}$ bergerak dari 0.299 hingga 0.594 sehingga sebanyak 7 aitem dinyatakan gugur. Total aitem yang digunakan dalam penelitian ini sebanyak 33 aitem untuk mengukur kepribadian ekstraversi subjek penelitian. Reliabilitas Skala Kepribadian Ekstraversi ini diuji dengan teknik Alpha Cronbach yang menunjukkan hasil $\alpha=0.886$. Sehingga, dapat disimpulkan Skala Kepribadian Ekstraversi ini sudah reliabel karena sudah memenuhi koefisien reliabilitas yang baik, yaitu di atas 0.6 (Sugiyono, dalam Siswanto, dkk., 2017).

Hasil uji validitas terhadap Skala Kesepian ini menunjukkan nilai $r_{i x}$ bergerak dari 0.268 hingga 0.674 sehingga sebanyak 3 aitem dinyatakan gugur. Total aitem yang digunakan dalam penelitian ini sebanyak 37 aitem untuk mengukur kesepian pada subjek penelitian. Reliabilitas Skala Kesepian ini diuji dengan teknik Alpha Cronbach yang menunjukkan hasil $\alpha=0.920$. Sehingga, dapat disimpulkan Skala Kesepian ini sudah reliabel karena 
sudah memenuhi koefisien reliabilitas yang baik, yaitu di atas 0.6 (Sugiyono, dalam Siswanto, dkk., 2017).

Setelah mendapatkan hasil uji validitas dan reliabilitas yang baik, peneliti kemudian menyebarkan angket kepada 123 remaja yang menjadi subjek dalam penelitian ini. Setelah data terkumpul, selanjutnya peneliti melakukan pengolahan data dan uji hipotesis dengan Pearson Product Moment Correlation.

Hasil Pearson Product Moment Correlation dapat dikatakan tidak menyimpang apabila memenuhi syarat uji asumsi klasik data yang mana mensyaratkkan data harus terdistribusi normal dan memiliki hubungan linear antar variabel yang diteliti (Hadi, dalam Siswanto, dkk., 2017). Berdasarkan hasil analisis, ditemukan bahwa semua syarat untuk menggunakan teknik Pearson Product Moment Correlation terpenuhi, yaitu data terdistribusi normal dan kedua variabel yang peneliti teliti yaitu kepribadian ekstraversi dan kesepian memiliki hubungan yang linear.

\section{H A S I L}

Tabel 1. Data Deskriptif Kepribadian Ekstraversi dan Kesepian

\begin{tabular}{lll}
\hline & $\begin{array}{l}\text { Kepribadian } \\
\text { Ekstraversi }\end{array}$ & Kesepian \\
\hline Skor Minimum & 37 & 76 \\
\hline Skor Maksimum & 132 & 147 \\
\hline Skor Rata-rata & 71.26 & 105.8 \\
\hline Standar Deviasi & 15.858 & 15.938 \\
\hline Kategori Rendah (Persentase) & $39(31.71 \%)$ & $0(0 \%)$ \\
\hline Kategori Sedang (Persentase) & $82(66.66 \%)$ & $76(61.79 \%)$ \\
\hline Kategori Tinggi (Persentase) & $2(1.63 \%)$ & $47(38.21 \%)$ \\
\hline
\end{tabular}

Berdasarkan data pada tabel 1, untuk variabel kepribadian ekstraversi, terdapat 39 subjek (31.71 persen) yang memiliki kepribadian ekstraversi rendah, terdapat 82 subjek (66.66 persen) yang memiliki kepribadian ekstraversi sedang, dan terdapat 2 subjek (1.63 persen) yang memiliki kepribadian ekstraversi tinggi. Berdasarkan penjelasan di atas maka dapat disimpulkan bahwa rata-rata subjek penelitian memiliki kepribadian ekstraversi sedang.

Dari skala kepribadian ekstraversi yang diisi subjek, maka diperoleh mean empirik sebesar 70.3 dengan standar deviasi 16.5. Apabila mean empirik > mean hipotetik maka hasil penelitian yang diperoleh akan dinyatakan tinggi dan sebaliknya jika mean empirik $<$ mean hipotetik maka hasil penelitian akan dinyatakan rendah. Hasil analisis untuk skala kepribadian ekstraversi diperoleh mean empirik < mean hipotetik yaitu $71.26<82.5$ maka dapat disimpulkan bahwa kepribadian ekstraversi pada subjek penelitian lebih rendah daripada populasi pada umumnya. 
Selanjutnya, untuk hasil kategorisasi variabel kesepian dari jumlah subjek 123 remaja menunjukkan bahwa tidak terdapat subjek (0 persen) yang memiliki kesepian rendah, terdapat 76 subjek (61.79 persen) yang memiliki kesepian sedang, dan terdapat 47 subjek (38.21 persen) yang memiliki kesepian tinggi. Berdasarkan penjelasan tersebut maka dapat disimpulkan bahwa rata-rata subjek penelitian memiliki kesepian sedang.

Dari skala kesepian yang diisi subjek, maka diperoleh mean empirik sebesar 105.8 dengan standar deviasi 15.938. Apabila mean empirik $>$ mean hipotetik maka hasil penelitian yang diperoleh akan dinyatakan tinggi dan sebaliknya jika mean empirik < mean hipotetik maka hasil penelitian akan dinyatakan rendah. Hasil analisis untuk skala kesepian diperoleh mean empirik > mean hipotetik yaitu 105.8>92.5 maka dapat disimpulkan bahwa kesepian pada subjek penelitian lebih tinggi daripada populasi pada umumnya.

Hasil uji normalitas sebaran dilakukan agar dapat mengetahui apakah setiap variabel penelitian telah terdistribusi secara normal atau tidak. Uji normalitas sebaran dalam penelitian ini menggunakan uji Kolmogorov Smirnov Test. Data dikatakan terdistribusi normal jika p>0.05 (Priyatno, 2011). Berdasarkan hasil uji normalitas sebaran, dapat diketahui uji normalitas sebaran pada variabel kepribadian ekstraversi diperoleh koefisien sig 1 (satu) arah dari variabel kepribadian ekstraversi sebesar 0.203 ( $p>0.05$ ), yang berarti bahwa data pada variabel kepribadian ekstraversi memiliki sebaran atau terdistribusi normal. Uji normalitas sebaran yang dilakukan terhadap variabel kesepian diperoleh koefisien sig uji 1 (satu) arah dari variabel kesepian sebesar 0.386 ( $\mathrm{p}>0.05)$, yang berarti bahwa data pada variabel kesepian memiliki sebaran atau terdistribusi normal.

Uji linearitas hubungan dimaksudkan untuk mengetahui derajat hubungan antara variabel bebas dengan variabel terikat dalam penelitian ini, yaitu kepribadian ekstraversi dan kesepian, sebagai syarat dilakukannya pengujian analisis data korelasional Pearson Product Moment dengan tujuan untuk melihat apakah kedua variabel tersebut memiliki hubungan yang linear atau tidak. Sebagai kriterianya apabila nilai signifikansi <0,05 maka dinyatakan memiliki derajat hubungan yang linear. Berdasarkan hasil pada hasil pengujian linearitas, dapat dilihat nilai sig sebesar 0.000 yang mana $\mathrm{p}<0.05$, sehingga dapat disimpulkan bahwa kedua variabel memiliki hubungan linear dan telah memenuhi syarat untuk dilakukan analisis Pearson Product Moment Correlation.

\section{Tabel 2. Hasil Uji Hipotesis}

\begin{tabular}{lllllll}
\hline Analisis & $\begin{array}{l}\text { Pearson } \\
\text { Moment }\end{array}$ & Product & $\mathrm{R}$ & R Square & $\begin{array}{l}\text { Std. Error of the } \\
\text { Estimate }\end{array}$ & \\
\hline Koefisien & -0.731 & & -0.731 & 0.534 & 10.921 & \\
\hline Sig. & 0.000 & & & & & \\
\hline
\end{tabular}

Berdasarkan hasil uji hipotesis dengan teknik Pearson Product Moment Correlation pada tabel 2 ditemukan bahwa terdapat hubungan negatif yang kuat dan signifikan antara kepribadian ekstraversi dengan kesepian $(r=-0.731, \mathrm{p}=0.000<0.05)$. Hal ini menunjukkan 
bahwa adanya korelasi negatif yang signifikan antara kepribadian ekstraversi dengan kesepian sehingga dikategorikan hubungan yang kuat (Priyatno, 2011). Dari hasil perhitungan tersebut, maka hipotesis yang diajukan dalam penelitian ini menunjukkan terdapat hubungan negatif antara kepribadian ekstraversi dengan kesepian pada remaja yang tinggal di Panti Asuhan Al Jam'iyatul Washliyah Pulo Brayan dapat diterima.

Dalam penelitian ini diperoleh koefisien determinasi $\left(\mathrm{R}^{2}\right)$ sebesar 0.534. Berdasarkan hasil tersebut, dapat disimpulkan bahwa sumbangan 53.4 persen kepribadian ekstraversi memengaruhi kesepian dan selebihnya sebesar 46.6 persen dipengaruhi oleh faktor-faktor lain yang tidak diteliti pada penelitian ini, seperti kecerdasan sosial, dukungan keluarga, kepribadian introversi, cybervictimization, penggunaan internet, kualitas komunikasi, kebutuhan afiliasi, presentasi diri, psychological well-being, dan self disclosure. Dengan demikian, dapat diambil kesimpulan bahwa semakin tinggi kepribadian ekstraversi yang dimiliki remaja yang tinggal di Panti Asuhan Al Jam'iyatul Washliyah Pulo Brayan maka semakin tinggi kesepian yang mereka rasakan. Sebaliknya, semakin rendah kepribadian ekstraversi yang dimiliki remaja yang tinggal di Panti Asuhan Al Jam'iyatul Washliyah Pulo Brayan maka semakin rendah kesepian.

\section{DISKUSI}

Hasil penelitian ini menunjukkan adanya hubungan negatif yang kuat dan signifikan antara kepribadian ekstraversi dengan kesepian pada remaja Panti Asuhan Al Jam'iyatul Washliyah Pulo Brayan Medan. Hubungan yang negatif ini menjelaskan semakin tinggi kepribadian ekstraversi pada remaja yang tinggal di Panti Asuhan Al Jam'iyatul Washliyah Pulo Brayan Medan, maka semakin rendah kesepian yang mereka rasakan. Sebaliknya, semakin rendah kepribadian ekstraversi pada remaja yang tinggal di Panti Asuhan Al Jam'iyatul Washliyah Pulo Brayan Medan, maka semakin tinggi kesepian yang mereka rasakan. Sehingga, hipotesis yang diajukan dalam penelitian ini diterima.

Temuan penelitian ini sesuai dengan pernyataan yang dipaparkan oleh Uruk dan Demir (dalam Bevinn, 2011) bahwa kesepian dapat dihubungkan dengan dan juga berpotensi dipengaruhi oleh trait kepribadian, shyness, dan kepribadian ekstraversi. Hawkley (dalam Riva \& Eck, 2016) juga menegaskan bahwa kepribadian ekstraversi dapat memengaruhi tingkat kesepian seseorang. Semakin tinggi kepribadian ekstraversi yang dimiliki seseorang, maka tingkat kesepian akan semakin rendah. Sehingga, kepribadian ekstraversi berkorelasi negatif dengan kesepian, yang berarti rendahnya kepribadian ekstraversi juga dapat berdampak pada tingginya perasaan kesepian.

Hasil yang senada juga didapatkan pada penelitian yang dilakukan oleh Saklofske dan Yackulic (1989) tentang "Personality Predictors of Loneliness" pada 258 mahasiswamahasiswi pada sebuah universitas menunjukkan adanya korelasi yang negatif antara kepribadian ekstraversi dengan kesepian pada mahasiswa laki-laki juga pada mahasiswi perempuan. Penelitian senada yang dilakukan oleh Nayyar dan Singh (2011) pada 100 mahasiswa-mahasiswi Universitas Panjab, Chandigarh menunjukkan bahwa terdapat hubungan negatif yang signifikan antara kepribadian ekstraversi dan kesepian. Hal ini menunjukkan semakin tinggi kepribadian ekstraversi pada mahasiswa-mahasiswi 
Universitas Panjab maka semakin rendah kesepian. Individu yang memiliki kepribadian ekstraversi yang tinggi lebih menyukai dilibatkan dalam suatu aktivitas sosial dan memiliki jaringan pertemanan mereka sendiri selain dari keluarga. Sehingga, individu dengan kepribadian ekstraversi yang tinggi merasa lebih puas dalam kualitas relasi sosialnya dan minim merasakan kesepian.

Hasil penelitian ini juga sejalan dengan beberapa penelitian yang telah dilakukan sebelumnya yaitu penelitian Vanhalst, dkk., (2013) terhadap 428 keluarga yang berpartisipasi dalam penelitian ini dan menunjukkan adanya korelasi negatif yang signifikan antara kepribadian ekstraversi dengan kesepian. Hasil penelitian ini berbunyi semakin tinggi kepribadian ekstraversi, maka semakin rendah kesepian dan sebaliknya, semakin rendah kepribadian ekstraversi, maka semakin tinggi kesepian. Orang-orang yang merasakan kesepian memiliki kontak interpersonal dan interaksi dengan orang lain yang lebih sedikit, juga akibat dari dukungan jaringan sosial yang kurang luas. Berbagai studi yang telah dilakukan menunjukkan orang yang kesepian memiliki kepribadian ekstraversi yang rendah. Hasil penelitian lain yang dilakukan oleh Nayyar dan Singh (2011) pada 100 mahasiswa-mahasiswi Universitas Panjab, Chandigarh juga menunjukkan bahwa terdapat hubungan negatif yang signifikan antara kepribadian ekstraversi dan kesepian. Hal ini menunjukkan semakin tinggi kepribadian ekstraversi pada mahasiswa-mahasiswi Universitas Panjab maka semakin rendah kesepian dan sebaliknya semakin rendah kepribadian ekstraversi yang dimiliki mahasiswa-mahasiswi Universitas Panjab maka semakin tinggi kesepian yang mereka rasakan.

Berdasarkan observasi dan wawancara lanjutan terhadap remaja yang tinggal di Panti Asuhan Al Jam'iyatul Washliyah Pulo Brayan sebanyak 82 subjek atau 66.66 persen menunjukkan tingkat kepribadian ekstraversi pada kategori sedang. Aspek sociability menonjol dalam menggambarkan kepribadian ekstraversi pada subjek dengan kategori sedang pada remaja yang tinggal di Panti Asuhan Al Jam'iyatul Washliyah Pulo Brayan. Para subjek menyatakan bahwa kemampuan mereka tidak pernah diakui oleh temantemannya. Berdasarkan informasi yang mereka berikan, sering kali teman-temannya menyepelekan apapun yang dapat mereka kerjakan dengan baik. Misalnya, salah seorang subjek mengaku bahwa pada Hari Minggu para anak panti melakukan kegiatan kebersihan. Pengurus panti sering meminta para anak panti lainnya untuk mencontoh si subjek tersebut karena kebersihannya. Namun, anak panti yang lain malah sering memandangnya sedang mencari perhatian dan hal yang ia kerjakan memanglah hal yang mudah. Aspek positive emotions juga dapat menggambarkan kepribadian ekstraversi yang berada di kategori sedang pada remaja yang tinggal di Panti Asuhan Al Jam'iyatul Washliyah Pulo Brayan. Sebagai seorang remaja, salah tugas perkembangannya adalah membangun relasi sosial dan membangun hubungan intim dengan lawan jenisnya. Namun, jika tugas perkembangan ini tidak terpenuhi, remaja dapat merasakan perasaan sedih dan kesepian. Hal ini sesuai dengan hasil wawancara yang telah dilakukan pada remaja panti, para subjek merasa sedih karena tidak memiliki banyak teman untuk diajak berbicara.

Sebanyak 39 subjek atau 31.71 persen subjek menunjukkan tingkat kepribadian ekstraversi pada kategori rendah. Hasil wawancara pada para subjek menunjukkan bahwa para remaja panti asuhan juga sering merasa pesimis akan masa depan mereka. Hal ini 
membuat para remaja tidak tekun dalam belajar. Alasan lain yang mereka kemukakan adalah karena minimnya dukungan dari orang lain. Aspek activation juga menonjol dalam menggambarkan rendahnya kepribadian ekstraversi pada remaja yang tinggal di Panti Asuhan Al Jam'iyatul Washliyah Pulo Brayan. Para subjek menyatakan bahwa mereka menjadi enggan untuk berbicara dengan orang yang baru dikenal dan lebih pasif dalam hubungan sosial, baik itu pada anak panti asuhan yang baru masuk ataupun orang luar yang datang berkunjung.

Dari keseluruhan data yang telah diperoleh, hanya ditemukan 2 subjek atau 1.63 persen subjek yang memiliki kepribadian ekstraversi pada kategorisasi yang tinggi. Hasil wawancara menunjukkan para subjek cenderung senang untuk belajar segala sesuatu yang sebelumnya belum mereka pelajari, terutama menyangkut life skills. Beberapa kali di panti asuhan ini telah dilakukan penelitian dan beberapa di antaranya merupakan penelitian yang bersifat eksperimental yang diberikan kepada para subjek untuk mengatasi permasalahan-permasalahan yang dialami oleh para subjek. Para subjek mengaku tertarik untuk belajar hal-hal yang belum mereka ketahui tersebut. Hal tersebut menunjukkana aspek impulsive sensation-seeking ditemukan menonjol pada para subjek. Selain pada aspek impulsive sensation-seeking, aspek positive emotions juga dominan pada subjek dengan kepribadian ekstraversi yang tinggi. Berdasarkan wawancara yang telah dilakukan, para subjek mengaku senang jika ada anak-anak panti lain yang mencari mereka. Mereka merasa diinginkan dan diakui sebagai seorang teman. Sehingga, mereka merasa diterima dan tidak merasa diasingkan.

Selain kepribadian ekstraversi, penelitian ini juga meneliti kesepian remaja yang tinggal di Panti Asuhan Al Jam'iyatul Washliyah Pulo Brayan. Sebanyak subjek 123 remaja menunjukkan bahwa tidak terdapat subjek (0 persen) yang memiliki kesepian rendah, terdapat 76 subjek (61.79 persen) yang memiliki kesepian sedang, dan terdapat 47 subjek (38.21 persen) yang memiliki kesepian tinggi. Berdasarkan penjelasan tersebut, dapat dipahami remaja yang tinggal di Panti Asuhan Al Jam'iyatul Washliyah Pulo Brayan rata-rata memiliki kesepian yang berada pada kategori tinggi.

Berdasarkan observasi dan wawancara lanjutan terhadap remaja yang tinggal di Panti Asuhan Al Jam'iyatul Washliyah Pulo Brayan sebanyak 76 subjek atau 61.79 persen subjek menunjukkan tingkat kesepian yang sedang. Peneliti menemukan para subjek menyatakan bahwa teman-teman di sekeliling mereka tidak semuanya ingin berteman dengan mereka. Hal ini membuat para subjek merasa sedih karena tidak memiliki siapapun di samping mereka. Para subjek juga merasa menghadapi permasalahannya seorang diri. Selain aspek kesepian emosional, aspek kesepian sosial juga ditemukan menonjol pada subjek yang berada pada kategori sedang. Hasil wawancara yang peneliti lakukan menggambarkan para subjek merasa bosan dengan pertemanan yang mereka miliki saat ini. Setelah peneliti melakukan wawancara lebih lanjut, mereka pun mengaku merasa jenuh karena harus tinggal di panti asuhan dengan ruang lingkup pertemanan mereka hanyalah dengan anak-anak panti asuhan saja. Kontak dengan teman di luar panti sangat minim mereka lakukan karena adanya peraturan yang diterapkan di panti asuhan. Selain itu, para subjek mengaku dalam suatu diskusi sekalipun, pendapat, ide, dan saran mereka seringkali diabaikan begitu saja oleh teman-temannya. 
Sebanyak 47 subjek atau 38.21 persen subjek memiliki kesepian yang berada pada kategori tinggi dan dapat dilihat dari aspek kesepian emosional. Hasil wawancara yang peneliti dapatkan, para subjek sering merasa tidak berarti bagi siapapun. Perasaan ini muncul ketika mereka merasa tidak ada yang peduli dan memperhatikan mereka, terutama di saat mereka sedang sakit. Selain pada aspek kesepian emosional, aspek kesepian sosial juga dominan pada para subjek yang memiliki kesepian yang berada pada kategori tinggi. Diketahui dari wawancara yang telah peneliti lakukan, para subjek mengaku masih merasa asing di panti asuhan. Perasaan asing ini muncul karena mereka merasa tidak ada seorang pun yang menanyakan kondisi mereka ketika mereka tidak nampak dan muncul dalam kelompok. Pertemanan yang mereka miliki hanya berdasarkan tatap muka yang mereka lakukan sehari-hari dan di lingkungan sekolah dan panti saja.

Tidak terdapat subjek yang memiliki kesepian pada kategori rendah. Wawancara lanjutan yang telah peneliti lakukan pada para subjek menggambarkan bahwa banyak di antara mereka merindukan teman-teman mereka dulu. Terlebih ketika sedang memiliki masalah. Para subjek mengaku merasa keberadaan mereka sering kali diabaikan oleh teman-teman yang lain. Hal ini membuat para subjek lebih sering memendam segala permasalahannya seorang diri dan membuat mereka tidak mudah percaya akan pertemanan yang sedang mereka jalani.

Berdasarkan wawancara yang telah dilakukan, dapat diketahui bahwa perasaan kesepian yang dimiliki oleh para subjek juga dipengaruhi oleh minimnya kedekatan sosial yang terjalin. Para subjek mengaku ingin menjalin pertemanan dan dekat dengan anak-anak lainnya, namun niat pertemanan tersebut tidak terlaksana karena alasan yang mereka sendiri tidak ketahui. Sehingga para subjek merasa asing dengan panti dan bosan dengan pertemanan yang ada di sana.

Bordens dan Horowitz (2008) berpendapat bahwa perasaan kesepian selalu disertai dengan perasaan negatif seperti depresi, kecemasan, ketidakbahagiaan, dan ketidakpuasan yang diasosiasikan dengan pesimisme, self-blame, dan rasa malu. Hal ini sesuai dengan apa yang terjadi pada beberapa remaja yang tinggal di Panti Asuhan Al Jam'iyatul Washliyah Pulo Brayan. Dimana remaja yang merasakan kesepian cenderung merasakan perasaan-perasaan negatif seperti sedih, kecewa, marah, dan merasa diasingkan oleh teman sebayanya.

Keterbatasan penelitian ini terdapat pada jumlah subjek yang hanya berjumlah 123 remaja yang berusia 13-16 tahun, berstatuskan yatim/piatu/yatim-piatu, dan tinggal menetap di Panti Asuhan Al Jam'iyatul Washliyah Pulo Brayan Medan. Keterbatasan ini terjadi karena terbatasnya jumlah subjek yang memenuhi kriteria subjek penelitian. Hal lain yang menjadi kelemahan penelitian ini adalah peneliti hanya menggunakan salah satu trait kepribadian yakni kepribadian ekstraversi saja. Sehingga, tidak dapat diketahui hubungan trait-trait kepribadian lainnya seperti agreeableness, conscientiousness, openness to experience, dan neuroticism dengan kesepian. 


\section{SIMPULAN DAN IMPLIKASI}

Berdasarkan hasil penelitian yang telah diperoleh, dapat dipahami bahwa hipotesis yang diajukan dalam penelitian ini dapat diterima, dimana terdapat hubungan negatif yang signifikan antara kepribadian ekstraversi dengan kesepian pada remaja yang tinggal di Panti Asuhan Al Jam'iyatul Washliyah Pulo Brayan Medan. Hal tersebut direfleksikan dari hasil koefisien korelasi Pearson Product Moment dengan r=-0.731, p<0.001. Kepribadian ekstraversi memberikan kontribusi sebesar $53.4 \%$ terhadap kesepian pada subjek penelitian dan $46.6 \%$ sisanya dipengaruhi oleh faktor lain yang tidak diteliti.

Implikasi penelitian ini bagi para peneliti selanjutnya, kiranya dapat menemukan variabel moderator yang menghubungkan kepribadian ekstraversi dengan kesepian ataupun dapat menguji traits kepribadian lainnya dengan kesepian. Penelitian ini juga diharapkan dapat menjadi masukan bagi panti asuhan agar dapat membantu mengurangi perasaan kesepian yang dimiliki remaja yang tinggal di panti asuhan dengan cara mendorong remaja untuk lebih terbuka dengan lingkungan sosialnya dan bersedia menjadi pendengar aktif dalam mendengar keluh-kesah dan permasalahan yang dialami remaja yang tinggal di panti asuhan karena kebutuhan anak panti asuhan tidak hanya sebatas kebutuhan sandang dan pangan semata. Anak-anak yang tinggal di panti asuhan juga membutuhkan pemenuhan kebutuhan psikologis seperti perhatian orang tua yang dapat diberikan oleh pengurus, pengawas, maupun pimpinan panti asuhan.

\section{REFERENSI}

Baron, R. A., \& Branscombe, N. R. (2012). Social Psychology $13^{\text {th }}$ Edition. United States of America : Pearson Education.

Bevinn, S. J. (2011). Psychology of Loneliness. New York : Nova Science Publishers, Inc.

Bordens, K. S., \& Horowitz, I. A. (2008). Social Psychology: Third Edition. United States of America : Freeload Press.

Cecen, A. R. (2007). The Turkish Short Version of The Social and Emotional Loneliness Scale for Adults (SELSA-S): Initial Development and Validation. Social Behavior and Personality, 35(6), 717-734.

Johnson, G. Y. (2014). I Am Here: Opening The Windows To Life And Beauty. United Kingdom : O-Books.

Margalit, M. (2010). Lonely Children and Adolescents. London : Springer Science + Business Media LLC.

Myers, D. G. (2012). Social Psychology. United States of America : Mc Graw Hill. 
Nayyar, S., \& Singh, B. (2011). Personality Correlates of Loneliness. Journal of the Indian Academy of Applied Psychology January 2011, 37(1)), 163-168.

Priyatno, D. (2011). Teknik Mudah dan Cepat Melakukan Analisis Data Penelitian dengan SPSS. Yogyakarta : Gaya Media.

Riva, P., \& Eck, J. (2016). Social Exclusion: Psychological Approaches to Understanding and Reducing its Impact. Switzerland : Springer Nature.

Sarinah. (2017). Minat Berwirausaha Ditinjau dari Kepribadian Extraversion pada Mahasiswa Fakultas Ekonomi Universitas Dharmawangsa Medan. Jurnal Diversita, 3(1), 32-39.

Siswanto, Susila, \& Suyanto. (2017). Metodologi Penelitian Kombinasi Kualitatif Kuantitatif Kedokteran dan Kesehatan. Klaten : Bossscript.

Utami, D. R., Ahmad, R., \& Ifdil. (2017). Tingkat Kesepian Remaja di Panti Asuhan X Kota Padang. Jurnal Konseling GUSJIGANG, 3(1), 1-6.

Vanhalst, J., Goosens, L., Luyckx, K., Scholte, R. H. J., \& Engels, R. C. M. E. (2013). The Development of Loneliness from Mid- to Late Adolescence: Trajectory Classes, Personality Traits, and Psychosocial Functioning. Journal of Adolescence 36(6), 1305-1312.

Victor, C., Sasha, S., \& John, B. (2009). The Social World of Older People. New York : Two Penn Plaza.

Weiner, I. B. (2003). Handbook of Psychology, Volume 5: Personality and Social Psychology. New Jersey : John Wiley \& Sons, Inc. 


\title{
KUALITAS HIDUP DITINJAU DARI HARAPAN PADA PASIEN WANITA PENDERITA KANKER
}

\author{
David Junovandy ${ }^{1}$, Rianda Elvinawanty ${ }^{2}$, Winida Marpaung ${ }^{3}$ \\ ${ }^{1,2,3}$ Fakultas Psikologi Universitas Prima Indonesia \\ e-mail: ${ }^{1}$ davidjunovandy@gmail.com
}

\begin{abstract}
Abstrak. Jumlah pasien kanker di Indonesia selalu meningkat setiap tahunnya. Pada pasien kanker sering ditemukan permasalahan fisik, psikologis, relasi sosial, dan lingkungan. Penelitian ini bertujuan untuk mengetahui hubungan antara harapan dengan kualitas hidup pada pasien wanita penderita kanker. Hipotesis yang diajukan adalah terdapat hubungan positif antara harapan dengan kualitas hidup. Subjek penelitian dalam penelitian ini adalah pasien wanita penderita kanker di Murni Teguh Memorial Hospital sebanyak 136 orang yang dipilih dengan metode purposive sampling. Teknik analisis data yang digunakan dalam penelitian ini adalah Pearson Product Moment Correlation dengan bantuan program SPSS 19.00 for Windows. Hasil analisis data menunjukkan koefisien korelasi sebesar 0.712 ( $\mathrm{p}<0.001$ ). Hasil ini menunjukkan terdapat hubungan positif yang signifikan antara harapan dengan kualitas hidup. Temuan ini dapat digunakan oleh pasien kanker sebagai dasar peningkatan kualitas hidup dimana pasien kanker perlu menumbuhkan harapan. Pasien kanker yang memiliki aspek psikologis positif seperti harapan dapat menangguhkan pasien dalam memandang kehidupannya.
\end{abstract}

Kata kunci: harapan, kualitas hidup, pasien kanker, wanita

\begin{abstract}
The case of cancer patients in Indonesia increases in every year. Patients often found physical, psychological, social relationship, and environmental problems. This study aims to find relationship between hope and quality of life. The hypothesis proposed is that there is a positive relationship between hope and quality of life. The subjects of this study were women patients who suffering cancer in Murni Teguh Memorial Hospital consisting of 136 patients selected by using purposive sampling method. The data analysis technique used in this study is the Pearson Product Moment Correlation through the help of SPSS 19.00 for Windows. The results of data analysis showed a correlation coefficient of $0.712(\mathrm{p}<0.001)$. It showed that there is a positive relationship between hope and quality of life. These findings can be used by cancer patients as a basis for improving the quality of life, cancer patients need to increase hope. Patients who have positive psychological aspects such as the hope could make patients have a good perspective at their lives.
\end{abstract}

Keywords: hope, quality of life, cancer patient, women 
Sehat merupakan keinginan setiap orang tanpa terkecuali. Namun, dalam rentang kehidupan manusia, manusia juga tidak luput dari berbagai macam penyakit, baik penyakit yang ringan hingga penyakit yang berat dan mematikan. Organisasi Kesehatan Dunia (dalam Diatmi \& Fridari, 2012) mendefinisikan sehat sebagai suatu keadaan fisik, mental, dan kesejahteraan sosial yang lengkap, bukan hanya ketiadaan penyakit atau kelemahan. Namun, perubahan gaya hidup dapat berdampak pada perubahan kesehatan manusia, terutama pada imunitas tubuhnya. Salah satu penyakit dari gaya hidup yang tidak sehat adalah kanker.

Kementerian Kesehatan RI (2015) menyatakan kanker merupakan salah satu penyebab kematian utama di seluruh dunia. Menurut Yayasan Kanker Indonesia (www.yayasankankerindonesia.org), kanker adalah penyakit akibat pertumbuhan tidak normal dari sel-sel jaringan tubuh yang berubah menjadi sel kanker. Senada dengan hal tersebut, Kelvin dan Tyson (2011) juga menyatakan bahwa kanker dimulai dengan perubahan struktur dan fungsi sel yang menyebabkan sel membelah dan berkembang biak tak terkendali. Sel selanjutnya dapat menyerang dan menyebabkan kerusakan jaringan di sekitarnya, melepaskan diri, dan menyebar ke bagian tubuh lainnya.

Data yang dihimpun oleh GLOBOCAN tahun 2012 menunjukkan bahwa jumlah kematian akibat kanker telah mencapai 8,2 juta kematian dari seluruh jenis kanker yang ada (Kementerian Kesehatan RI, 2015). Kanker dapat ditemukan baik pada pria maupun wanita. Secara khusus, pada pasien kanker wanita, perubahan fisik akibat kanker dapat terlihat secara kasat mata. Perubahan fisik ini dapat berupa bentuk dari pengobatan, seperti operasi pengangkatan payudara pada wanita penderita kanker payudara atau yang lebih dikenal dengan istilah mastectomy. Perubahan fisik lainnya juga dapat berupa pengangkatan rahim pada pasien kanker endometrium.

Permasalahan tersebut menunjukkan adanya permasalahan kualitas hidup pada pasien kanker, khususnya pada pasien wanita di aspek fisik, psikologis, hubungan sosial, dan lingkungan. Hal ini mendorong peneliti untuk melakukan survei pada pasien wanita penderita kanker di Murni Teguh Memorial Hospital Medan. Berdasarkan survei yang telah peneliti lakukan, peneliti mendapati para pasien wanita penderita kanker memandang kehidupannya dengan cara yang berbeda setelah diagnosis kanker ditegakkan. Mereka mengaku berputus asa, merasa berdosa, dan khawatir akan kehidupan mereka. Sebagian dari mereka juga merasa semakin dekat dengan kematian, khawatir tentang kehidupan rumah tangganya setelah ia sakit, dan mencemaskan masa depan anak-anak mereka. Para pasien kanker ini juga tak jarang memiliki permasalahan dengan body image mereka karena salah satu payudara mereka harus diangkat untuk mencegah kankernya bermetastase. Bahkan, demi mendapatkan pengobatan, mereka juga harus membayar nominal yang tidak sedikit. Biaya pemeriksaan medis, kemoterapi, radioterapi, pembedahan, dan obat-obatan yang mereka konsumsi tidak berkisaran pada nominal kecil. Hal ini yang juga menjadi beban finansial bagi para pasien kanker dan keluarga tentunya.

Berdasarkan survei yang telah peneliti lakukan, dapat disimpulkan bahwa para pasien wanita penderita kanker memiliki kualitas hidup yang rendah. Rendahnya kualitas hidup para pasien wanita penderita kanker ditandai dengan banyaknya gangguan fisik yang 
mereka rasakan setelah menderita kanker. Mereka mengaku setelah menjalani proses kemoterapi, mereka merasakan mual dan muntah yang hebat. Secara psikologis, banyak dari mereka belum mampu menerima kondisi mereka dengan penyakit ini. Mereka mengaku bahwa mereka menjadi sulit tidur dan lebih banyak berpikir tentang kematian yang menghantui mereka. Permasalahan hubungan sosial pun mereka rasakan, mereka mengaku menjadi lebih terbatas dalam berkomunikasi dengan keluarga dan teman-teman mereka. Hal ini terjadi karena terbatasnya energi dan stamina yang mereka miliki. Selain itu, mereka juga perlu menjaga kondisi tubuh mereka yang rentan tertular penyakit setelah kemoterapi karena imunitas yang menurun. Aspek lingkungan juga dapat memengaruhi kualitas hidup pasien wanita penderita kanker, yang paling mereka khawatirkan adalah kondisi finansial keluarga yang terguncang karena biaya pengobatan kanker tidaklah murah. Hal-hal tersebut menunjukkan rendahnya kualitas hidup pasien wanita penderita kanker.

Organisasi Kesehatan Dunia (dalam Diatmi \& Fridari, 2012) menyatakan kualitas hidup adalah persepsi dari individu dalam kehidupan meliputi konteks budaya dan sistem nilai dimana mereka hidup dalam kaitannya dengan nilai-nilai, standar, dan kekhawatiran dalam hidup. Bowling (dalam Prastiwi, 2012) berpendapat bahwa kriteria kualitas hidup yang positif ditentukan oleh bagaimana seseorang dapat memiliki pandangan psikologis yang positif, memiliki kesejahteraan emosional, memiliki kesehatan fisik dan kesehatan mental yang baik, memiliki kemampuan fisik untuk melakukan hal-hal yang ingin dilakukan, memiliki hubungan yang baik dengan teman dan keluarga, berpartisipasi dalam kegiatan sosial dan rekreasi, tinggal dalam lingkungan yang aman dengan fasilitas yang baik, memiliki uang yang cukup, dan mandiri.

Primardi dan Hadjam (2010) dalam penelitian mereka yang menguji hubungan antara harapan dengan kualitas hidup pada orang dengan epilepsi menemukan adanya hubungan yang positif dan signifikan antara harapan dengan kualitas hidup. Seseorang yang memiliki harapan yang tinggi memiliki energi yang lebih untuk memotivasi diri berperan aktif dalam penyelesaian masalah dan terus berkembang. Soylu, dkk., (2016) juga mendapatkan hasil yang sama dimana terdapat hubungan positif dan signifikan antara harapan dengan kualitas hidup pada 55 pasien wanita penderita kanker payudara.

Seorang psikolog, Lazarus (dalam Howell \& Larsen, 2015) menuliskan bahwa harapan adalah percaya pada sesuatu yang positif, yang saat ini tidak berlaku dalam kehidupan seseorang, namun masih dapat terwujud. Menurut Snyder (2000) harapan dapat didefinisikan sebagai pemikiran yang diarahkan pada tujuan, di mana orang menilai kemampuan mereka untuk menghasilkan jalan yang dapat dikerjakan dengan tujuan (pemikiran mencapai tujuan), bersama dengan potensi mereka untuk memulai dan mempertahankan gerakan melalui jalur (pemikiran penentu perilaku).

Peneliti mencoba mengaitkan fenomena harapan dengan kualitas hidup yang dimiliki oleh pasien wanita penderita kanker. Kualitas hidup yang rendah dapat dimiliki oleh pasien kanker ketika diagnosis kanker ditegakkan. Para pasien kanker mengaku sempat merasa putus asa dan merasa semakin dekat dengan kematian. Perasaan putus asa ini menunjukkan rendahnya harapan pada pasien kanker tersebut. 
Penelitian terdahulu yang menghubungkan harapan dengan kualitas hidup pernah dilakukan oleh Souza dan Kamble (2016) yang menemukan hubungan positif dan signifikan antara harapan dengan kualitas hidup pada 397 pasien kanker dewasa. Hal ini merefleksikan tingginya harapan pada pasien kanker berhubungan dengan kualitas hidup yang baik. Pasien kanker yang memiliki aspek positif seperti harapan dapat mendorong pasien memiliki ketangguhan dalam menghadapi penyakit yang membawa outcome medis yang lebih baik.

Berdasarkan uraian-uraian sebelumnya, maka peneliti tertarik untuk meneliti hubungan antara harapan dengan kualitas hidup pada pasien wanita penderita kanker di Murni Teguh Memorial Hospital. Adapun yang membedakan penelitian ini dengan penelitian terdahulu adalah karakteristik subjek dalam penelitian yang meliputi pasien wanita penderita kanker, baik itu kanker payudara, kanker serviks, kelenjar getah bening, kanker rahim, dan lainnya, guna mendapatkan gambaran kualitas hidup pasien wanita penderita kanker yang lebih luas dibanding spesifik pada satu jenis kanker saja. Tujuan dari penelitian ini untuk mengetahui hubungan antara harapan dengan kualitas hidup. Manfaat praktis yang diharapkan dari penelitian ini jika hipotesis diterima adalah dibentuknya hope group support yang mana terdiri dari para pasien yang telah dinyatakan sembuh dan setiap relawan yang dapat berkomitmen untuk mendorong dan memotivasi para pasien kanker untuk menumbuhkan harapan sehingga kualitas hidup mereka dapat lebih baik. Hipotesis yang diajukan dalam penelitian ini adalah terdapat hubungan positif dan signifikan antara harapan dengan kualitas hidup. Dengan asumsi semakin tinggi harapan maka semakin tinggi kualitas hidup subjek penelitian demikian pula sebaliknya, semakin rendah harapan pada subjek maka semakin rendah kualitas hidupnya.

\section{METODE}

Penelitian ini menggunakan metode penelitian kuantitatif dengan teknik analisis korelasional. Siswanto, dkk., (2017) menjelaskan penelitian korelasional sebagai teknik pengelolaan data dengan cara mengorelasikan atau menghubungkan dua data variabel atau lebih untuk mengetahui tingkat keeratan hubungan. Penelitian ini bertujuan untuk mengungkapkan hubungan antara harapan dengan kualitas hidup.

Penelitian ini menggunakan 2 (dua) variabel, yaitu variabel bebas dan variabel terikat. Variabel bebas dalam penelitian ini adalah harapan dan variabel terikatnya adalah kualitas hidup. Harapan yang dimaksud dalam penelitian ini adalah gabungan dari keyakinan, keinginan, dan pemikiran yang berarah pada suatu tujuan yang bersifat positif dan pada saat ini belum dicapai namun masih dapat dicapai. Harapan pada subjek penelitian diukur dengan Skala Harapan yang peneliti kembangkan berdasarkan komponen-komponen harapan Snyder dan Lopez (2002) yang meliputi komponen goal, komponen pathway thinking, komponen agency thinking, dan komponen kombinasi pathway thinking dan agency. Semakin tinggi skor yang diperoleh subjek menunjukkan semakin tingginya harapan pada subjek. Semakin rendah skor yang diperoleh subjek menunjukkan semakin rendahnya harapan pada subjek. Kualitas hidup yang dimaksud dalam penelitian ini adalah evaluasi berdasarkan objektif dan/atau subjektif persepsi individu tentang posisinya dalam kehidupan dari keadaan fisik, kognitif, dan emosional, 
sehubungan dengan tujuan, harapan, standar, nilai, dan perhatiannya dalam konteks budaya dan sistem nilai dimana mereka hidup dan dalam kaitannya dengan nilai-nilai, standar, dan kekhawatiran dalam hidup. Kualitas hidup pada subjek penelitian diukur dengan Skala Kualitas Hidup yang peneliti kembangkan berdasarkan aspek-aspek kualitas hidup menurut WHOQOL-BREF (dalam Rapley, 2003) yang terdiri dari aspek kesehatan fisik, aspek psikologis, aspek hubungan sosial, dan aspek lingkungan. Peneliti menggunakan 4 respon alternatif jawaban untuk menghindari respon tengah demi meminimalisir permasalahan tendensi sentral.

Partisipan yang dilibatkan dalam penelitian ini dipilih dengan metode purposive sampling. Purposive sampling yaitu teknik penentuan sampel dengan pertimbangan tertentu (Sugiyono, dalam Siswanto, dkk., 2017). Pertimbangan yang ditetapkan adalah pasien wanita penderita kanker di Murni Teguh Memorial Hospital Medan, berusia 20-45 tahun, sudah menikah, dan dapat berkomunikasi dengan baik. Jumlah subjek yang didapatkan sebanyak 136 pasien wanita penderita kanker.

Skala Harapan dan Skala Kualitas Hidup masing-masing terdiri dari 40 aitem sebelum dilakukan uji coba terpakai. Setelah dilakukan uji coba terpakai dengan teknik Corrected Item Total Correlation dengan bantuan program SPSS 19.0 for Windows, didapatkan 10 aitem gugur dan 30 aitem valid untuk Skala Harapan dan 5 aitem gugur dan 35 aitem valid untuk Skala Kualitas Hidup. Koefisien validitas butir yang valid pada Skala Harapan bergerak dari nilai 0,308-0,621. Reliabilitas Skala Harapan ditemukan sangat tinggi dengan $\alpha=0.917$. Koefisien validitas butir yang valid untuk Skala Kualitas Hidup bergerak dari nilai 0,308-0,630. Reliabilitas Skala Kualitas Hidup dengan $\alpha=0.912$. Hal ini menunjukkan daya diskriminasi aitem pada kedua skala tersebut sudah baik dan begitu pula dengan reliabilitasnya setelah dilakukan uji reliabilitas dengan teknik Alpha Cronbach dengan bantuan program SPSS 19.0 for Windows.

Sebelum dilakukan pengujian hipotesis dengan Pearson Product Moment Correlation, terlebih dahulu dilakukan uji asumsi klasik yang meliputi uji normalitas sebaran dengan rumus Kolmogorov Smirnov $Z$ dan uji linearitas hubungan dengan test linearity dalam program SPSS 19.00 for Windows agar kesimpulan yang ditarik tidak menyimpang dari kebenaran yang seharusnya ditarik (Hadi, dalam Siswanto, dkk., 2017).

\section{HASIL}

Uji normalitas sebaran dilakukan agar dapat mengetahui apakah setiap variabel penelitian telah tersebar secara normal atau tidak. Dengan uji Kolmogorov Smirnov Test ditemukan pada variabel harapan diperoleh koefisien $\mathrm{KS}-\mathrm{Z}=1.195$ dengan sig sebesar 0.115 untuk uji 2 (dua) arah. Karena hipotesis yang diajukan dalam penelitian ini bersifat 1 (satu) arah, maka sig 1 (satu) arah dari variabel harapan sebesar 0.058 (p>0.05), yang berarti bahwa data pada variabel harapan memiliki sebaran atau berdistribusi normal. Sedangkan pada pengujian normalitas sebaran yang dilakukan terhadap variabel kualitas hidup diperoleh koefisien $\mathrm{KS}-\mathrm{Z}=0.695$ dengan sig sebesar 0.719 untuk uji 2 (dua) arah. Karena hipotesis yang diajukan dalam penelitian ini bersifat 1 (satu) arah, maka sig uji 1 (satu) arah dari variabel kualitas hidup sebesar 0.36 ( $\mathrm{p}>0.05)$, yang berarti bahwa data pada variabel kualitas hidup memiliki sebaran atau berdistribusi normal. 
Hasil yang diperoleh dari pengujian linearitas hubungan menunjukkan bahwa variabel harapan dan variabel kualitas hidup memiliki hubungan linear. Hal ini didapatkan dari nilai sig yang diperoleh yaitu $0.000 *$ maka $p<0.05$, sehingga dapat disimpulkan bahwa harapan dan kualitas hidup memiliki hubungan linear dan telah memenuhi syarat untuk dilakukan analisis korelasi Pearson Product Moment Correlation.

Tabel 1. Hasil Uji Hipotesis

\begin{tabular}{lccc}
\hline \multicolumn{1}{c}{ Variabel } & $\begin{array}{c}\text { Pearson } \\
\text { Correlation }\end{array}$ & Sig & $R$ Square \\
\hline $\begin{array}{l}\text { Harapan dan } \\
\text { Kualitas Hidup }\end{array}$ & $0.712^{* *}$ & 0.000 & 0.507 \\
\hline **signifikansi pada taraf $0.01($ 1-tailed $)$ & &
\end{tabular}

Berdasarkan hasil analisis korelasi antara harapan dengan kualitas hidup, diperoleh koefisien korelasi Pearson Product Moment sebesar $0.712^{* *}$ dengan sig sebesar $\mathrm{p}<0.001$. Hal ini menunjukkan bahwa adanya korelasi positif yang signifikan antara harapan dengan kualitas hidup sehingga dikategorikan hubungan yang kuat. Nilai $R$ Square sebesar 0.507 menunjukkan variabel harapan dapat memengaruhi kualitas hidup sebesar 50.7\%, sehingga selebihnya, $49.3 \%$ dipengaruhi oleh faktor lain yang tidak diteliti. Dari hasil perhitungan tersebut, maka hipotesis yang diajukan dalam penelitian ini menunjukkan ada hubungan positif dan signifikan antara harapan dengan kualitas hidup pada pasien wanita penderita kanker di Murni Teguh Memorial Hospital Medan, diterima.

Tabel 2. Perbandingan Data Mean Empirik dan Hipotetik

\begin{tabular}{lcc}
\hline \multirow{2}{*}{ Variabel } & \multicolumn{2}{c}{ Mean } \\
\cline { 2 - 3 } & Empirik & Hipotetik \\
\hline Harapan & 86.51 & 75 \\
\hline Kualitas Hidup & 99.09 & 87.5 \\
\hline
\end{tabular}

Hasil analisis untuk skala harapan diperoleh mean empirik > mean hipotetik yaitu 86.51>75 maka dapat disimpulkan bahwa harapan pada subjek penelitian lebih tinggi daripada populasi pada umumnya. Kemudian, hasil analisis untuk skala kualitas hidup diperoleh mean empirik > mean hipotetik yaitu 99.09>87.5 maka dapat disimpulkan bahwa kualitas hidup pada subjek penelitian lebih tinggi daripada populasi pada umumnya. 
Tabel 3. Kategorisasi Data

\begin{tabular}{lcccc}
\hline Variabel & Kategori & Jumlah (n) & Persentase \\
\hline Harapan & Rendah & 1 & $0.7 \%$ \\
\cline { 2 - 5 } & & Sedang & 85 & $62.5 \%$ \\
\cline { 2 - 5 } & Jumggi & 50 & $36.8 \%$ \\
\hline \multirow{2}{*}{ Kualitas Hidup } & & 136 & $100 \%$ \\
& & Rendah & 0 & $0 \%$ \\
\cline { 2 - 4 } & & Sedang & 94 & $69 \%$ \\
\cline { 2 - 4 } & & Tinggi & 42 & $31 \%$ \\
\hline & Jumlah & & 136 & $100 \%$ \\
\hline
\end{tabular}

Berdasarkan pada tabel kategorisasi tersebut, dapat dilihat pada variabel harapan terdapat 1 subjek (0.7 persen) yang memiliki harapan rendah, terdapat 85 subjek (62.5 persen) yang memiliki harapan sedang, dan terdapat 50 subjek (36.8 persen) yang memiliki harapan tinggi. Sedangkan untuk variabel kualitas hidup, dapat dilihat bahwa tidak terdapat subjek ( 0 persen) yang memiliki kualitas hidup rendah, terdapat 94 subjek (69 persen) yang memiliki kualitas hidup sedang, dan terdapat 42 subjek (31 persen) yang memiliki kualitas hidup tinggi.

\section{DISKUSI}

Hasil penelitian ini menunjukkan adanya hubungan positif yang kuat dan signifikan antara harapan dengan kualitas hidup pada pasien wanita penderita kanker di Murni Teguh Memorial Hospital Medan. Hubungan yang positif ini menjelaskan semakin tinggi harapan pada pasien wanita penderita kanker, maka semakin tinggi juga kualitas hidup yang mereka miliki. Sebaliknya, semakin rendah harapan yang dimiliki pasien wanita penderita kanker, maka semakin rendah juga kualitas hidup yang mereka miliki. Sehingga, hipotesis yang diajukan dalam penelitian ini diterima.

Soylu, dkk., (2016) mendapatkan hasil hubungan positif dan signifikan antara harapan dengan kualitas hidup pada 55 pasien wanita penderita kanker payudara. Pada penelitian yang senada, Souza dan Kamble (2016) juga menemukan hubungan yang positif dan signifikan antara harapan dengan kualitas hidup pada 397 pasien kanker dewasa. Hal ini merefleksikan tingginya harapan pada pasien kanker berhubungan dengan kualitas hidup yang baik. Pasien kanker yang memiliki aspek positif seperti harapan dapat mendorong pasien memiliki ketangguhan dalam menghadapi penyakit yang membawa outcome medis yang lebih baik. Hasil penelitian lain yang mempertegas hasil hubungan positif antara harapan dengan kualitas hidup dilakukan oleh Li, dkk., (2016) yang dilakukan pada pasien bladder cancer menemukan harapan memiliki hubungan positif terhadap kualitas hidup pada 365 pasien bladder cancer.

Hasil penelitian ini sesuai dengan pendapat Sirgy (2002) yang menyatakan bahwa harapan dapat meningkatkan kualitas hidup. Senada dengan pendapat tersebut, kelompok World Health Organization of Quality of Life (dalam Preedy \& Watson, 2010) menjelaskan kualitas hidup sebagai persepsi seseorang tentang posisinya dalam 
kehidupan sehubungan dengan tujuan, harapan, standar, nilai, dan perhatiannya. Hal ini menunjukkan bahwa harapan individu dalam hidup dapat menentukan kualitas hidupnya.

Harapan terbesar setiap pasien kanker pada umumnya bertahap. Berdasarkan hasil yang diperoleh dari wawancara yang telah dilakukan, para pasien pada awalnya memiliki harapan agar setiap rasa sakit seperti nyeri dan denyut yang mereka rasakan dapat berkurang. Disarankan untuk para pasien kanker mengikuti anjuran dokter untuk setiap pengobatan. Misalnya dengan operasi pembedahan yang diperlukan pada pasien kanker payudara ataupun pada pasien kanker endometrium. Selanjutnya, para pasien mengaku berharap dapat beraktivitas seperti sebelum mereka sakit. Untuk mencapainya, disarankan kepada para pasien agar rutin mengonsumsi suplemen makanan maupun obat stamina sesuai dengan anjuran dokter guna menyuplai tambahan tenaga. Makan yang teratur dan dengan komposisi gizi yang seimbang mampu para pasien memiliki stamina yang lebih baik, tidak hanya itu, hasil cek lab klinik juga menunjukkan komponen darah yang lebih baik pada pasien yang memiliki diet sesuai dengan anjuran dokter. Perbaikanperbaikan kualitas fisik ini akan mendorong pasien memiliki perasaan-perasaan yang lebih baik jika dapat dicapai. Kualitas fisik yang baik akan mendorong para pasien kanker memiliki hubungan sosial yang lebih baik lagi.

Hubungan antara harapan dengan kualitas hidup tidak hanya dilakukan pada para pasien penderita kanker saja. Peneliti lain juga menguji hubungan antara kedua variabel tersebut pada pasien dengan penyakit terminal lainnya. Yadav (2010) dalam penelitian pada orang dengan HIV dan AIDS di Nepal telah menemukan bahwa harapan berkorelasi positif dengan kualitas hidup secara global dan semua domain kualitas hidup. Sedangkan pada penelitian yang dilakukan oleh Bluvol dan Ford-Gilboe (2004) pada 40 pasien penderita dan keluarga pasien penderita stroke menunjukkan adanya korelasi yang positif moderat antara harapan dengan kualitas hidup pada penderita stroke dan pada keluarga pasien penderita stroke. Hasil yang ditemukan adalah semakin tinggi harapan, maka semakin tinggi kualitas hidup pada pasien stroke dan sebaliknya, semakin rendah harapan, maka semakin rendah kualitas hidup pada pasien stroke.

Penelitian yang senada juga pernah dilakukan Wu (2011) terhadap 175 korban kriminalisasi yang mengalami trauma di Taiwan. Ia menemukan bahwa harapan secara signifikan berhubungan dengan kualitas hidup para korban kriminalisasi tersebut. Hubungan antara harapan dengan kualitas hidup juga pernah diteliti terhadap pada pasien post polio syndrome. Penelitian tersebut dilakukan oleh Shiri, dkk., (2012) dan mendapatkan hasil adanya hubungan positif dan signifikan antara harapan dengan kualitas hidup pada 60 pasien post polio syndrome.

Berdasarkan uraian-uraian tersebut, dapat disimpulkan bahwa harapan memiliki hubungan yang positif dengan kualitas hidup. Hubungan yang positif ini tidak hanya ditemukan pada pasien kanker saja, pada pasien dengan penyakit lain seperti HIV/AIDS, stroke, dan post polio syndrome juga didapatkan harapan berhubungan dengan kualitas hidup. Hal ini menunjukkan harapan berperan secara signifikan dalam memengaruhi kualitas hidup pada manusia.

Berdasarkan hasil kategorisasi skor pada variabel kualitas hidup, dapat dilihat bahwa tidak terdapat subjek (0 persen) yang memiliki kualitas hidup rendah, terdapat 94 subjek 
(69 persen) yang memiliki kualitas hidup sedang, dan terdapat 42 subjek (31 persen) yang memiliki kualitas hidup tinggi. Hal ini menunjukkan bahwa sebagian besar pasien wanita penderita kanker memiliki kualitas yang sedang dan tinggi. Tingginya skor kualitas hidup pada subjek penelitian ditunjukkan dengan data hasil penelitian yang menunjukkan para pasien kanker merasakan berkurangnya rasa mual dan muntah sehabis kemoterapi seiring berjalannya siklus kemoterapi. Mereka juga optimis akan sembuh setelah melihat beberapa pasien lain yang semakin baik dan prima kondisinya. Kondisi yang semakin prima membuat para pasien ini dapat beraktivitas sebagaimana sedia kala, mereka dapat berkunjung ke rumah sanak saudaranya maupun berkomunikasi via telepon dengan teman-temannya. Kondisi finansial sedikit terguncang namun mereka yang memiliki asuransi maupun BPJS Kesehatan merasa sedikit terbantu dalam hal pemeriksaan dan pengobatan karena Murni Teguh Memorial Hospital telah bekerja sama dengan BPJS Kesehatan demi mewujudkan masyarakat yang sehat. Hasil ini tentunya kurang sesuai dengan hasil survei awal. Hal ini mungkin terjadi karena kualitas hidup merupakan sebuah konstruk yang luas. Sehingga, pasien mendapatkan skor yang rendah pada salah satu aspek, namun pada dua atau tiga aspek lainnya, ia dapat memiliki skor yang tinggi.

Berdasarkan hasil kategorisasi skor pada variabel harapan terdapat 1 subjek ( 0.7 persen) yang memiliki harapan rendah, terdapat 85 subjek (62.5 persen) yang memiliki harapan sedang, dan terdapat 50 subjek (36.8 persen) yang memiliki harapan tinggi. Hal ini menunjukkan bahwa sebagian besar pasien wanita penderita kanker memiliki harapan yang sedang dan tinggi. Tingginya skor harapan pada subjek penelitian ditunjukkan dengan data hasil penelitian yang menunjukkan para subjek memiliki tujuan untuk sembuh dari penyakit yang mereka derita. Selain itu, mereka juga mengembangkan berbagai cara yang dapat mereka tempuh demi mencapai kesembuhan. Dari cara-cara tersebut, mereka yakin setidaknya terdapat beberapa cara untuk mencapai kesembuhan, baik dengan menjaga pola makan, mengikuti jadwal berobat yang telah ditetapkan dokter, konsultasi rutin, kemoterapi, radioterapi, dan lain-lain. Hasil ini tentunya juga kurang sesuai dengan survei awal dimana para pasien awalnya mengaku berputus asa ketika diagnosis kanker ditegakkan. Hal ini mungkin terjadi karena setelah menjalani beberapa kali siklus kemoterapi, pasien merasakan perbaikan kesehatan fisik yang signifikan dibarengi dengan pengakuan-pengakuan pasien kanker lain yang juga merasakan hal yang sama. Selain itu, Murni Teguh Memorial Hospital juga sering memberikan seminar awam dengan testimoni pasien kanker yang telah sembuh. Seminar awam tersebut dapat diikuti oleh siapapun, sehingga harapan untuk sembuh pada para pasien kanker tersebut pun meningkat.

Individu yang memiliki harapan tinggi memiliki tujuan dalam hidupnya, mampu mengembangkan suatu cara untuk mencapai tujuannya, dan memiliki keyakinan mampu untuk mencapai tujuannya melalui cara-cara yang ia kembangkan. Goal jangka pendek dan jangka panjang ini membuat individu memiliki optimisme yang tinggi untuk sembuh. 


\section{SIMPULAN DAN IMPLIKASI}

Berdasarkan hasil penelitian yang telah diperoleh, dapat dipahami bahwa hipotesis yang diajukan dalam penelitian ini dapat diterima, dimana terdapat hubungan positif yang signifikan antara harapan dengan kualitas hidup pada pasien wanita penderita kanker di Murni Teguh Memorial Hospital Medan. Hal tersebut direfleksikan dari hasil koefisien korelasi Pearson Product Moment dengan $\mathrm{r}=0.712$, $\mathrm{p}<0.001$. Harapan yang tinggi pada pasien wanita penderita kanker dapat membantu mereka memiliki kualitas hidup yang tinggi dan sebaliknya rendahnya harapan pada pasien wanita penderita kanker juga dapat memprediksi kualitas hidup yang rendah. Harapan memberikan kontribusi sebesar 50.7\% terhadap kualitas hidup pada subjek penelitian dan $49.3 \%$ sisanya dipengaruhi oleh faktor lain yang tidak diteliti.

Implikasi penelitian ini bagi para pasien wanita penderita kanker agar dapat menumbuhkan harapan dengan belajar dari pengalaman pasien kanker lain yang telah sembuh, sehingga pemikiran pasien kanker dapat berfokus pada tujuan untuk mencapai kesembuhan. Hal ini akan mendorong motivasi pasien kanker dan keyakinan pribadi dalam diri pasien kanker bahwa mereka akan sembuh jika mengikuti segala pengobatan dan perawatan kesehatan yang akan memobilisasi proses perbaikan kualitas kesehatan fisik, psikis, maupun sosial pasien kanker.

Implikasi bagi para peneliti selanjutnya yang ingin meneruskan penelitian ini, diharapkan dapat meluaskan area penelitian, tidak hanya pada satu rumah sakit saja. Selain itu, dapat juga melibatkan para pasien kanker pria. Dalam operasionalnya, peneliti lain juga dapat melibatkan variabel bebas lainnya, misalnya optimisme, resiliensi, kesepian, psychological adjustment styles, dan lain-lain.

\section{REFERENSI}

Bluvol, A., \& Ford-Gilboe, M. (2004). Hope, Health Work, and Quality of Life in Families of Stroke Survivors. Journal of Advanced Nursing, 48 (4), 322-332.

Diatmi, K., \& Fridari, I. G. A. D. (2014). Hubungan antara Dukungan Sosial dengan Kualitas Hidup pada Orang dengan HIV dan AIDS (ODHA) di Yayasan Spirit Paramacitta. Jurnal Psikologi Udayana, 1, (2), 353-362.

Kementerian Kesehatan RI. (2015). Stop Kanker. Jakarta: Pusat Data dan Informasi Kementerian Kesehatan RI.

Kelvin, J. F. \& Tyson, L. B. (2011). 100 Questions \& Answers About Cancer Symptoms and Cancer Treatment Side Effects $2^{\text {nd }}$ Edition. USA: Jones \& Bartlett Publisher, LLC.

Li, M. Y., Yang, Y. L., \& Wang, L. (2016). Effects of Social Support, Hope, and Resilience on Quality of Life among Chinese Bladder Cancer Patients. Health and Quality of Life Outcomes, 14, (1), 1-9. DOI: 10.1186/s12955-016-0481-z. 
Prastiwi, T. F. (2012). Kualitas Hidup Penderita Kanker. Developmental and Clinical Psychology, 1, (1), 21-27.

Preedy, V. R. \& Watson, R. R. (2010). Handbook of Disease Burdens and Quality of Life Measures. USA: Springer.

Primardi, A. \& Hadjam, M. N. R. (2010). Optimisme, Harapan, Dukungan Sosial Keluarga, dan Kualitas Hidup Orang dengan Epilepsi. Jurnal Psikologi, 3,(2), 123133.

Rapley, M. (2003). Quality of Life Research A Critical Introduction. London: Sage Publications.

Shiri, S., Wexler, I. D., Feintuch, U., Meiner, Z., \& Schwartz, I. (2012). Post Polio Syndrome: Impact of Hope on Quality of Life. Disability \& Rehabilitation, 31, (10), 824-830.

Sirgy, M. J. (2002). The Psychology of Quality of Life. USA: Springer Science+Bussiness Media Dordrecht.

Siswanto, Susila, \& Suyanto. (2017). Metodologi Penelitian Kombinasi Kualitatif Kuantitatif Kedokteran dan Kesehatan. Klaten: Bossscript

Snyder, C. R. (2000). Handbook of Hope Theory, Measures. San Diego: Academic Press.

Snyder, C. R., \& Lopez, S. J. (2002). Handbook of Positive Psychology. USA: Oxford University.

Souza, A. D., \& Kamble, S. V. (2016). Silver Lining and Hope in Relation with The Quality of Life in Adult Cancer Patients. The International Journal of Indian Psychology, 3, 2, (1), 24-31.

Soylu, C., Babacan, T., Sever, A. R., \& Altundag, K. (2016). Patients' Understanding of Treatment Goals and Disease Course and Their Relationship with Optimism, Hope, and Quality of Life: A Preliminary Study among Advanced Breast Cancer Outpatients before Receiving Palliative Treatment. Support Care Center, 24, (8), 3481-3488. DOI: 10.1007/s00520-016-3182-6.

Vacek, K. R., Coyle, R.D., \& Vera, E. M. (2010). Stress, Self-Esteem, Hope, Optimism, and Well Being in Urban, Ethnic Minority Adolescents. Journal of Multicultural Counseling and Development, 38, 99-111.

Wu, H. C. (2011). The Protective Effects of Resilience and Hope on Quality of Life of The Families Coping with The Criminal Traumatisation of One of Its Members. Journal of Clinical Nursing, 20, 1906-1915. DOI: $0.1111 / \mathrm{j} .1365-$ 2702.2010.03664.x

Yadav, S. (2010). Perceived Social Support, Hope, and Quality of Life of Persons Living with HIV/AIDS: a Case Study from Nepal. Quality of Life Research, 19, (2), 157166. DOI: $10.1007 / \mathrm{s} 11136-009-9574-\mathrm{Z}$ 


\title{
PERUNDUNGAN DAN SCHOOL WELL-BEING: PLACE ATTACHMENT SEBAGAI MODERATOR
}

\author{
Katarina Menik Astuti ${ }^{1}$, Ratna Djuwita ${ }^{2}$ \\ ${ }^{1,2}$ Program Magister Terapan Intervensi Sosial, Fakultas Psikologi, Universitas Indonesia \\ 1,2 katarinamenikastuti@gmail.com
}

\begin{abstract}
Abstrak. Salah satu bentuk perilaku yang dapat menurunkan school well being dan membuat iklim sekolah menjadi tidak menyenangkan adalah perundungan. Studi literatur menunjukkan bahwa selain perundungan, place attachment terhadap sekolah ternyata juga mempengaruhi school well being. Peneliti mengajukan hipotesis bahwa place attachment berperan sebagai moderator dalam hubungan antara perundungan dan school well being. Pengambilan data dilakukan pada 133 orang mahasiswa tingkat pertama dengan menggunakan kuesioner yang mengadaptasi alat ukur school well-being dan place attachment. Selain itu ditanyakan pula pengalaman perundungan responden saat di SMA. Hasil penelitian membuktikan bahwa place attachment berperan sebagai moderator dalam hubungan antara perundungan dengan school well-being; semakin tinggi place attachment maka semakin kuat hubungan negatif antara perundungan dengan school well-being. Hal ini menunjukkan bahwa place attachment dapat menjadi penangkal terhadap perundungan. Bagi siswa yang memiliki ikatan dan identifikasi diri yang kuat terhadap sekolah, maka perundungan yang terjadi tidak menurunkan school well-beingnya. Mereka akan tetap merasa nyaman bersekolah walaupun perundungan masih terjadi.
\end{abstract}

Kata Kunci: perundungan, place attachment, school well-being, moderator

Abstract. One form of behavior that can reduce school well-being and make unpleasant school climate is bullying. Literature studies shows, that besides bullying, place attachment to school also affects school well being. The researcher hypothesized that place attachment acts as a moderator in the relationship between bullying and school well being. Data collection was conducted on 133 first-degree students using a questionnaire adapting the school well-being and place attachment questionnaire. In addition, the questionnaire also asked about respondents' bullying experience when in high school. The results show that place attachment acts as a moderator in the relationship between bullying with school well-being: Higher place attachment will act as a buffer on bullying. Students who have strong bonds and identify themself strongly with their schools, their school well-being will not be harmed by bullying. This suggests that students with high place attachment can remain comfortable and happy in school, even though bullying still occurs in their schools.

Keywords: bullying, moderation, place attachment, school well-being 
Seiring tumbuh kembang seorang anak, ia akan semakin banyak berinteraksi dengan halhal lain di luar dirinya. Salah satu setting atau keadaan yang penting dalam tumbuh kembang anak adalah sekolah (Bronfenbrenner, 2009). Pengalaman yang diperoleh seorang anak di dalam sekolah dan interaksi di sekolah memiliki dampak terhadap kesuksesan akademis dan juga kemampuan penyesuaian diri seorang anak ketika ia sudah dewasa (Haynes, Emmons \& Ben-Avie, 1997). Iklim sekolah yang positif mempengaruhi persepsi siswa tentang sekolah sebagai tempat yang aman dan menyenangkan untuk belajar sehingga akan meningkatkan prestasi akademik dan menurunkan kekerasan (Beaudoin \& Roberge, 2015; Caprara, Kanacri, Gerbino, dkk, 2014). ). Iklim sekolah yang positif akan memunculkan well being siswa yang positif pula (Suldo, ThaljiRaitano, Hasemeyer dkk, 2013). Begitu pula sebaliknya, iklim sekolah yang negatif dapat memicu perilaku bermasalah seperti drop out (Ferero, McLellan, Rissel dkk, 1999), agresi (Wilson, 2004) dan perundungan (Bandyopadhyay, Cornell, \& Konold, 2009; Espelage, Low \& Jimerson, 2014; Nansel, Overpeck, Pilla dkk, 2001). Oleh karena itulah suasana sekolah atau iklim sekolah menjadi penting untuk diperhatikan.

Persepsi siswa terhadap keadaan sekolahnya berkaitan dengan sejauh apa sekolah memungkinkan siswa untuk memenuhi kebutuhan dasarnya atau disebut sebagai school well being (Konu \& Rimpela, 2002). Konu \& Rimpela (2002) memaparkan bahwa school well being seorang anak ditentukan oleh empat aspek yaitu kondisi sekolah secara fisik (having), kesehatan (health), pemaknaan self-fulfillment (being) dan hubungan sosial (loving) yaitu interaksi dengan semua komponen sekolah termasuk guru dan siswa lain. Siswa harus merasa bahwa sekolah memiliki fasilitas sekolah yang mendukung untuk belajar antara lain seberapa menariknya tatanan ruang kelas dan kualitas pencahayaan (Kumar, 2008). Kondisi fisik sekolah ini juga harus mendukung kesehatan fisik siswa, mulai dari faktor makanan hingga kelelahan fisik. Namun ternyata tidak hanya faktor fisik saja yang menjadi kebutuhan siswa, penghargaan atas kerja keras dan juga kesempatan pengembangan diri siswa di sekolah pun menjadi sebuah kebutuhan yang perlu dipenuhi oleh sekolah untuk dapat menciptakan school well being yang baik. Selain itu, siswa juga harus memiliki interaksi yang positif dengan sesama siswa maupun guru dan karyawan di sekolah. Aspek-aspek tersebut harus terpenuhi untuk dapat menciptakan lingkungan sekolah yang mendukung school well-being siswa.

Interaksi sosial yang positif di sekolah inilah yang menjadi sorotan karena memiliki pengaruh besar pada nyaman atau tidaknya seorang individu berada pada suatu lingkungan (Brown \& Perkins, 1992). Salah satu bentuk perilaku terkait interaksi sosial yang dapat menurunkan school well being dan membuat iklim sekolah menjadi tidak menyenangkan adalah bullying atau perundungan. Menurut Rigby (2011), perundungan adalah systematic abuse of power in interpersonal relations. Definisi tersebut menunjukkan bahwa perundungan berkaitan dengan pengendalian power atau kekuatan. Sesuai atau tidaknya seseorang atau sebuah kelompok menggunakan kekuatannya terhadap seseorang atau kelompok lainnya inilah yang menjadi tolak ukur sebuah perilaku perundungan. Dengan menggunakan kekuatan, pelaku perundungan memiliki tujuan untuk menimbulkan efek tertentu yang tidak menyenangkan pada korbannya.

Individu yang menjadi korban perundungan dapat menerima dampak yang sangat negatif, baik pada aspek sosialnya maupun personalnya. Rigby (2007) mengemukakan beberapa 
akibat dari perilaku perundungan, yaitu menurunnya self-esteem korban, isolasi dari pergaulan, tidak masuk sekolah, efek domino (dimana muncul fenomena bully/victim), menurunkan konsentrasi sehingga berpengaruh pada sisi akademis, kesehatan fisik dan yang paling fatal adalah bunuh diri. Namun tidak hanya korban yang mengalami dampak dari perundungan. Pelaku perundungan pada kenyataannya memiliki asosiasi dengan penyimpangan perilaku lainnya yang dapat terjadi di kemudian hari. Mereka juga memiliki kemungkinan yang lebih tinggi untuk terlibat pelanggaran hukum, depresi dan tertekan dalam rasa bersalahnya. Selain itu pada individu lain yang hanya tahu namun tidak terlibat (bystander/outsider), cenderung muncul ketakutan akan menjadi salah satu korban, sehingga memiliki kemungkinan untuk mencari rasa aman dengan menjadi pelaku juga di kemudian hari. Dampak yang muncul dari perundungan di sekolah mempengaruhi persepsi siswa akan kenyamanan dan keamanan di sekolah, termasuk menghambat perkembangan siswa dalam belajar, dengan kata lain, perundungan memiliki pengaruh pada school well being siswa. Itu sebabnya perundungan di sekolah memiliki dampak yang sangat memprihatinkan sehingga perlu dilakukan tindakan pencegahan dan penanggulangan.

Perilaku perundungan dapat dilihat dalam bentuk yang berbeda-beda. Olweus (2006) mengungkapkan perundungan dalam dua bentuk, yaitu langsung dan tidak langsung. Perundungan secara langsung merupakan bentuk perundungan berupa penyerangan secara terbuka terhadap korban sehingga korban mengetahui siapa pelakunya. Perilaku perundungan secara langsung dapat berupa kata-kata yang menyakitkan (perundungan secara verbal) dan juga dapat berupa tindakan-tindakan yang menyakitkan secara fisik (Scheithauer, 2006). Sedangkan perundungan secara tidak langsung berupa isolasi sosial dan mengucilkan seseorang secara sengaja dari sebuah kelompok. Bentuk perundungan secara tidak langsung ini disebut juga sebagai relational perundungan (Scheithauer, 2006). Berdasarkan pemaparan diatas, perundungan dapat dibedakan dalam tiga bentuk meliputi fisik, verbal dan relasional.

Perundungan merupakan sebuah masalah yang banyak terjadi di sekolah di dunia (Craig dkk., 2009; Smith, Cowie, Olafsson, \& Liefooghe, 2002) termasuk di Indonesia (Amini, 2008). Melihat adanya ketidaknyamanan yang muncul di sekolah karena adanya perundungan, menimbulkan pertanyaan apakah ada hal lain yang dapat mempengaruhi kenyamanan siswa di sekolah dan dipengaruhi oleh perundungan? Apa yang membuat siswa tetap bangga bersekolah di sekolah tersebut? Salah satu kemungkinan adalah adanya place attachment yang dimiliki siswa. Menurut Stedman (2002), place attachment didefinisikan sebagai ikatan antara individu dan lingkungannya berdasarkan kognisi dan emosi. "a bond between people and their environment based on cognition and emotion". Place attachment merupakan sebuah kondisi dimana sebuah tempat memiliki fungsi tertentu yang memberikan keuntungan pada orang tersebut sehingga kemudian muncul ketergantungan terhadap tempat tersebut. Place attachment dipandang sebagai suatu proses dinamis yang terjadi dari waktu ke waktu (Manzo, 2003). Semakin sering seseorang mengunjungi atau berada di suatu tempat dan memiliki pengalaman positif di suatu tempat, maka ikatan yang muncul pada tempat tersebut akan semakin kuat. Seiring berjalannya waktu yang dihabiskan di sebuah tempat, maka pengenalan akan tempat tersebut akan semakin baik dan seseorang juga akan mengalami berbagai pengalaman emosi. Biasanya hal ini akan membentuk ketergantungan pada tempat 
tersebut, sehingga kemudian terjadi ikatan emosional antara tempat dan manusia yang menempatinya (Stedman, 2002).

Schreyer, Jacob dan White (1981) mengemukakan adanya konsep menghargai atau memaknai sebuah keadaan yang meliputi pemaknaan fungsional dan emosional. Kedua bentuk pemaknaan tersebut yang mendasari pemikiran Williams dkk (1992) mengenai 2 dimensi dari place attachment, yaitu (1) Place dependence yang disebut juga sebagai functional attachment yang mencerminkan pentingnya suatu tempat karena menyediakan aspek-aspek atau kondisi yang mendukung tercapainya suatu tujuan tertentu, (2) Place identity yang disebut juga sebagai emotional attachment yang merujuk pada sebuah tempat yang menjadi simbol adanya emosi dan hubungan yang memberikan makna serta tujuan hidup. Place identity juga merujuk kepada self-identity seseorang dan dapat pula berkaitan dengan self esteem. Ketika seseorang memiliki ketergantungan dengan suatu tempat (place dependence) dan sering mengunjungi tempat tersebut maka dapat timbul place identity pada tempat tersebut.

Beberapa peneliti mengemukakan pemikiran bahwa place attachment memiliki kontribusi terhadap well-being fisik dan psikologis seseorang (Stokols \& Shumaker, 1982; Shumaker \& Taylor, 1983; Brown \& Perkins, 1992). Sehingga dapat disimpulkan bahwa selain perundungan, place attachment terhadap sekolah juga mempengaruhi school well being siswa. Manzo (2003) mengemukakan sebuah fenomena dimana sebuah kata 'home' menjadi luas maknanya, jika dipandang dari segi ikatan manusia dan tempat. Home yang umumnya dapat diartikan sebagai rumah atau sekadar tempat atau ruang, dapat juga diartikan sebagai pengalaman kegembiraan, perlindungan, kenyamanan dan rasa memiliki pada suatu tempat. Ketika sebuah tempat telah dipandang sebagai home bagi seseorang maka kepindahan, kerusakan dan kehilangan tempat tersebut dapat menimbulkan suatu emosi negatif pada individu tersebut (Inalhan, 2004). Sebaliknya jika tempat tersebut terus dapat digunakan dan ikatannya terbina maka self-identity dan selfconcept seseorang dapat terbina. Semakin tingginya ikatan seseorang terhadap suatu tempat, maka semakin tinggi pula keinginan untuk menjaga tempat tersebut (Brown, Perkins \& Brown, 2004). Brown dkk (2004) mengemukakan bahwa ikatan terhadap suatu tempat meningkatkan kepedulian seseorang terhadap tempat tersebut, sehingga dapat mengendalikan kriminalitas dan juga perusakan fasilitas di tempat tersebut. Hal ini menunjukkan bahwa dengan adanya keterikatan seorang siswa dengan sekolahnya maka keinginan untuk menjadikan sekolah sebagai tempat yang nyaman untuk belajar juga semakin tinggi.

Seorang individu dapat memiliki hubungan emosional terhadap daerah yang rutin dikunjungi dan melakukan kegiatan disana (Woods, 2006). Ikatan (attachment) yang muncul berdasarkan interaksi dengan individu lain dan pengalaman yang muncul dari interaksi tersebut. Sehingga ketika seseorang memiliki pengalaman yang negatif di suatu tempat tertentu maka tempat lain yang memiliki karakteristik yang sama akan menjadi lingkungan yang mencurigakan (Brown \& Perkins, 1992). Place attachment bukanlah sebuah kondisi tertentu namun merupakan proses yang berkelanjutan sepanjang hidup (Rubenstein dan Parmalee, 1992). Maka dari itu, pola reaksi yang muncul pada suatu setting tertentu berpengaruh pada seorang individu (Inalhan, 2004). Berdasarkan berbagai pemaparan sebelumnya, penulis melihat adanya kemungkinan bahwa pengaruh 
perundungan terhadap school well being dapat dipengaruhi oleh seberapa besar place attachment atau keterikatan siswa secara emosional terhadap sekolah itu sendiri, dengan kata lain hipotesis peneliti adalah place attachment merupakan moderator antara perilaku perundungan dengan school well being siswa.

\section{METODE}

Sampel penelitian adalah mahasiswa tahun pertama dari sebuh perguruan tinggi negeri. Persyaratan yang peneliti terapkan adalah responden harus lulus dari SMA dalam kurun waktu maksimal satu tahun. Peneliti memilih siswa yang telah lulus dari jenjang SMA karena alasan keterbukaan yang cenderung akan diberikan seseorang mengenai almamaternya setelah individu tersebut lulus, dibandingkan ketika individu tersebut masih berada pada tingkat SMA. Jika pengambilan data dilakukan pada siswa SMA, biasanya akan lebih sulit mendapatkan data yang sesuai dengan keadaan yang sesungguhnya dengan alasan tertentu, misalnya rasa takut. Berkaitan dengan kemudahan pengambilan data maka peneliti memilih mahasiswa tahun pertama di Fakultas Psikologi Universitas Indonesia sebagai responden atau sumber data yang dianggap mewakili populasi yang hendak diteliti. Teknik pengambilan sampel dalam penelitian ini adalah accidental sampling karena pemilihan responden berdasarkan ketersediaan responden ketika pengambilan data dilakukan saat itu (Kumar, 2005).

Penelitian ini tergolong penelitian kuantitatif, cross sectional, terapan dan retrospective (Kumar, 2005). Penelitian ini merupakan penelitian kuantitatif karena variabel school well-being, tingkat perundungan dan place attachment diukur dengan menggunakan kuesioner. Skor dari setiap kuesioner tersebut merupakan indikator dari tingkat school well-being, place attachment dan perundungan yang dipersepsikan responden. Responden hanya diminta untuk mengisi kuesioner sebanyak satu kali (cross-sectional study) dan sesuai dengan keadaan sebenarnya yang dialami responden. Penelitian ini juga merupakan penelitian terapan karena hasil dari penelitian ini dapat diterapkan pada situasi nyata sehari-hari. Hasil dari penelitian ini dapat digunakan sebagai informasi tambahan yang bermanfaat dalam intervensi perundungan. Selain itu penelitian ini merupakan penelitian retrospective karena pada penelitian ini responden diminta untuk mengungkapkan pengalamannya di masa lampau yaitu ketika responden berada di tingkat SMA. Terakhir, karena peneliti tidak melakukan manipulasi terhadap variabel yang diteliti maka penelitian ini tergolong penelitian non-eksperimental.

Instrumen yang digunakan dalam penelitian ini berupa kuesioner. Responden diminta mengisi seperangkat pertanyaan dan pernyataan terkait dengan pengalaman perundungan dan persepsi mereka terhadap keadaan school well-being dan place attachment ketika masa SMA dulu. Peneliti menggunakan alat ukur school well-being yang diadaptasi dari Konu dan Rimpela (2002). Alat ukur school well-being yang sudah diadaptasi ini terdiri dari 75 item yaitu 36 item yang mewakili dimensi having, 13 item yang mewakili dimensi loving, 14 item yang mewakili dimensi being, 12 item untuk mewakili dimensi health dan 2 item untuk saran pengembangan sekolah. Jumlah pilihan jawaban pada alat ukur ini adalah 5 respon jawaban, yaitu sangat setuju, setuju, biasa saja, tidak setuju dan 
sangat tidak setuju. Respon jawaban tersebut digunakan untuk mengukur dimensi having, loving, being, sedangkan untuk dimensi health, terdapat dua jenis respons jawaban yang digunakan yaitu sangat baik, baik, biasa saja, buruk dan sangat buruk serta tidak pernah, kadang, sekali sebulan, sekali seminggu dan hamper setiap hari. Alat ukur hasil adaptasi ini sudah melalui uji reliabilitas dengan 31 responden dengan karakteristik yang sama dan diperoleh koefisien alpha secara keseluruhan sebesar 0,945 untuk 75 item yang diuji. Berdasarkan uji validitas yang dilakukan, peneliti melakukan perbaikan dan menghilangkan beberapa item sehingga alat ukur yang digunakan berjumlah 42 item.

Alat ukur place attachment yang digunakan pada penelitian ini merupakan adaptasi dari alat ukur place attachment yang disusun oleh Williams dkk (1989) dengan penyesuaian item ke dalam konteks sekolah. Pada alat ukur ini terdapat 20 item yang terdiri dari 8 item untuk dimensi place dependence dan 12 item untuk dimensi place identity. Alat ukur ini menggunakan skala Likert dengan lima pilihan respon jawaban mulai dari sangat setuju hingga sangat tidak setuju. Uji reliabilitas dilakukan dengan data dari 31 responden dan diperoleh koefisien alpha secara keseluruhan sebesar 0,913. Terakhir, untuk melihat pengalaman perundungan responden, peneliti menggunakan beberapa item tambahan yang terdiri dari pilihan jawaban, dan pertanyaan terbuka. Pertanyaan terdiri dari 7 item yang berkaitan dengan pengalaman responden mengenai perilaku perundungan semasa sekolah. Pilihan jawaban yang dapat dipilih adalah Tidak Pernah (sama sekali tidak pernah), Jarang (kira-kira 1-2 kali dalam 1 tahun), Sering (kira-kira 12 kali dalam 1 bulan dan Selalu (hampir setiap waktu). Setelah memilih jawaban, responden diminta untuk memberikan contoh perilaku dari setiap jawaban yang diberikan, kecuali jika memilih Tidak Pernah. Pada akhir kuesioner, responden diminta mengisi data diri berupa jenis kelamin, jenis SMA, kota asal dan pernah atau tidaknya responden mengunjungi SMAnya setelah lulus. Proses pengerjaan kuesioner menghabiskan waktu kurang lebih 10 menit untuk tiap responden.

Pelaksanaan pengambilan data dilakukan selama tiga hari dengan menyebarkan 150 kuesioner. Pada akhir periode pengambilan data, hanya 136 yang dikembalikan kepada peneliti dan sebanyak 133 kuesioner yang dapat digunakan datanya. Data yang diperoleh kemudian diolah dengan menggunakan teknik statistik deskriptif untuk melihat gambaran umum mengenai karakteristik dari sampel penelitian, analisis mediasi dengan menggunakan conditional process analysis atau model PROCESS (Hayes, 2013) dan Independent Sample T-test untuk mengetahui signifikasi perbedaan mean antara jenis kelamin, jenis SMA dan kunjungan ke SMA dengan setiap variabel penelitian. Pengambilan data menggunakan kuesioner dan pengolahan secara statistik ini digunakan peneliti untuk membuktikan apakah place attachment merupakan moderator dalam hubungan antara perundungan dengan school well being. 


\section{HASIL}

Berdasarkan penghitungan deskriptif terhadap data responden diperoleh gambaran bahwa jumlah responden laki-laki dan perempuan kurang berimbang, yaitu 74,4\% responden berjenis kelamin perempuan dan sisanya laki-laki. Kurang lebih separuh dari responden berasal dari daerah Jakarta yaitu sebanyak $51,1 \%$, dan sisanya bersekolah di daerah Bodetabek. 66,2\% responden berasal dari sekolah negeri dan 33,8\% berasal dari SMA swasta. Sejak lulus dari SMA, sebagian besar responden, yaitu sebanyak $91 \%$ dari responden pernah berkunjung ke sekolahnya lagi, sedangkan sisanya tidak.

Hasil korelasi antar variabel menunjukkan adanya hubungan yang signifikan antar variabel pada $p<0,05$. Pada Tabel 1 di bawah ini terlihat adanya hubungan negatif antara persepsi perundungan dengan school well-being, $r=-0,23$, hubungan negatif antara persepsi perundungan dengan place attachment, $r=-0,27$ dan hubungan positif antara school wel-being dan place attachment.

Tabel 1

Hasil Korelasi Antar Variabel

\begin{tabular}{lccc}
\hline & Persepsi Perundungan & School Well-being & Place Attachment \\
\hline Persepsi Perundungan & - & $-0,23^{* *}$ & $-0,27^{* *}$ \\
\hline School Well-being & $-0,23^{* *}$ & - & $0,42^{* *}$ \\
\hline Place Attachment & $-0,27^{* *}$ & $0,42^{* *}$ & - \\
\hline
\end{tabular}

Berdasarkan analisis moderasi menggunakan model PROCESS diperoleh kesimpulan bahwa ketika place attachment rendah, tidak terdapat hubungan positif yang signifikan antara perundungan dengan school well-being, $\mathrm{b}=0,2 ; 95 \%$ CI $[-1,29 ; 1,69], t=0,27$, $p=0,79$, sedangkan ketika place attachment tinggi, terdapat hubungan negatif yang signifikan antara perundungan dengan school well-being, b=-2,38; 95\% CI [-4,2; -0,58], $t=-2,61, p<0,05$. Hasil penghitungan statistik tersebut membuktikan bahwa place attachment memoderasi hubungan antara perundungan dengan school well being siswa. Berdasarkan hasil tersebut, dapat dikatakan bahwa semakin tinggi ikatan seorang siswa dengan sekolah maka ia akan tetap dapat merasa bahagia di sekolah, walaupun ada perundungan yang terjadi.

Tabel 2

Hasil Penghitungan Moderasi

\begin{tabular}{lcccc}
\hline & $b$ & $s e$ & $t$ & $p$ \\
\hline Constant & 161 & 1,34 & 120,65 & $\mathrm{p}<0,05$ \\
& {$[158,4 ; 163,6]$} & & & $\mathrm{p}<0,05$ \\
\hline Place Attachment & 0,7 & 0,14 & 5,09 & $\mathrm{p}=0,058$ \\
& {$[0,4 ; 0,97]$} & & $-1,91$ & $\mathrm{p}<0,05$ \\
\hline Perundungan & $-1,08$ & 0,56 & & \\
\hline $\begin{array}{l}\text { Place Attachment } \\
\text { x Perundungan }\end{array}$ & $-2,2 ; 0,04]$ & & $-2,09$ & \\
\hline
\end{tabular}


Berdasarkan perhitungan school well-being dengan data demografis, terlihat bahwa tidak adanya perbedaan yang signifikan antar faktor jenis kelamin, yaitu laki-laki dan perempuan, faktor jenis SMA, yaitu sekolah swasta dan sekolah negeri dan faktor pernah tidaknya responden berkunjung ke SMA setelah lulus dalam school well-being responden ketika dulu masih bersekolah. Namun jika dilihat dari kota asal SMA, terlihat secara signifikan memiliki pengaruh terhadap school well-being, $\mathrm{F}(3,133)=3,285, \mathrm{p}<0,05$, Jakarta adalah kota asal SMA yang memiliki school well-being paling rendah yaitu dengan rata-rata 158,35, sedangkan responden yang sekolahnya berada di luar Jabodetabek memiliki school well-being yang paling tinggi dengan rata-rata 166,58.

Berdasarkan perhitungan perundungan dengan data demografis, terlihat bahwa tidak adanya perbedaan yang signifikan antar faktor jenis kelamin, yaitu laki-laki dan perempuan, faktor pernah tidaknya responden berkunjung ke SMA setelah lulus dengan perundungan yang dialami responden ketika dulu masih bersekolah dan faktor kota asal SMA. Sedangkan berdasarkan faktor jenis SMA, yaitu sekolah swasta dan sekolah negeri, terlihat memiliki perbedaan yang signifikan terhadap skor perundungan, dimana siswa di sekolah swasta lebih banyak mengalami perundungan $(M=6,2)$, dibandingkan dengan siswa di sekolah negeri $(M=5,67), t(133)=5,149, \mathrm{p}<0,05$,

\section{DISKUSI}

Pada perhitungan mediasi, peneliti memperoleh hasil bahwa tidak terdapat hubungan yang signifikan secara negatif antara perilaku perundungan di sekolah dengan school well being siswa. Hal ini bertolakbelakang dengan hasil analisa teori yang dilakukan sebelumnya, dimana perundungan dalam sudut pandang school well-being merupakan salah satu bentuk perilaku dari dimensi loving (Konu \& Rimpela, 2002). Perilaku perundungan di sekolah merupakan perilaku yang negatif yang dapat mempengaruhi persepsi siswa terhadap sekolahnya. Angka signifikansi yang mendekati 0,05 tersebut dapat dipengaruhi oleh jumlah data yang digunakan sehingga diasumsikan jika data ditambahkan maka hubungan keduanya dapat menjadi signifikan.

Dalam penghitungan hubungan setiap dimensi school well-being dengan place attachment, peneliti juga mendapatkan hasil bahwa tidak adanya hubungan antara dimensi health dari school well-being dengan place attachment. Hal tersebut mengindikasikan bahwa kesehatan seorang siswa di sekolah memang tidak memiliki hubungan dengan ikatannya dengan sekolah tersebut. Peneliti mengasumsikan hal tersebut disebabkan adanya keadaan fisik yang berbeda pada setiap individu sehingga ketika siswa menderita suatu ketidaknyamanan pada fisiknya belum tentu berhubungan dengan keadaan sekolahnya.

Selanjutnya, pada penelitian ini didapatkan hasil bahwa terdapat perbedaan school wellbeing pada siswa yang bersekolah di Jakarta, Bodetabek dan Luar Jabodetabek, dimana dapat dikatakan bahwa school well-being siswa yang bersekolah di Luar Jabodetabek memiliki school well-being yang lebih tinggi dibandingkan kedua daerah lainnya dan 
siswa di Jakarta memiliki school well-being yang paling rendah dibandingkan dengan kedua daerah lainnya. Hal tersebut kemungkinan dapat disebabkan oleh banyak hal, misalnya bentuk pergaulan yang berbeda antar daerah sehingga dapat mempengaruhi bentuk interaksi siswa di dalam sekolah. Peneliti juga mengasumsikan bahwa ukuran sekolah dapat berpengaruh terhadap kondisi fisik bangunan sekolah. Daerah di luar Jabodetabek diasumsikan relatif lebih lapang dibandingkan dengan daerah di Jakarta yang cenderung padat, sehingga sekolah yang dibangun di luar Jabodetabek diasumsikan lebih luas, khususnya untuk area bermain.

Berdasarkan data demografis juga didapatkan hasil bahwa terdapat perbedaan skor perundungan antara siswa yang bersekolah di sekolah swasta dan sekolah negeri, dimana dapat dikatakan bahwa perundungan lebih sering terjadi di sekolah swasta dibandingkan dengan sekolah negeri. Untuk hasil penelitian tersebut, peneliti mengasumsikan bahwa hal tersebut dipengaruhi oleh variasi latar belakang siswa yang bersekolah di sekolah negeri lebih banyak dibandingkan dengan siswa yang bersekolah di sekolah swasta. Status ekonomi siswa yang bersekolah di sekolah swasta juga umumnya cenderung tinggi karena biaya yang dikeluarkan untuk sekolah juga relatif lebih besar dibandingkan dengan sekolah negeri. Ketika seorang siswa yang memiliki status ekonomi relatif biasa saja masuk ke sekolah swasta maka siswa tersebut menjadi minoritas, sehingga kemudian terjadi ketimpangan kekuatan (power) antar kelompok siswa sehingga dapat menjadi faktor penunjang terjadinya perundungan (Rigby, 2011).

Pada penelitian ini juga didapatkan hasil bahwa tidak terdapat perbedaan place attachment jika dilihat dari kunjungan ke SMA. Sebelumnya peneliti mengasumsikan bahwa ketika seorang siswa memiliki ikatan dengan sekolahnya maka ia akan mengunjungi sekolahnya setelah lulus, dan sebaliknya ketika siswa tersebut tidak memiliki ikatan dengan sekolahnya maka ia lebih cenderung tidak akan mengunjungi sekolahnya setelah lulus. Namun hasil penelitian membuktikan bahwa asumsi tersebut tidak sesuai karena seberapapun ikatan siswa pada sekolahnya tidak berhubungan dengan kunjungan ke sekolahnya setelah lulus. Hal tersebut dapat disebabkan oleh adanya kebutuhan lain untuk mengunjungi sekolah lagi setelah lulus, misalkan untuk urusan administrasi seperti ijazah atau legalisir surat. Kunjungan ke sekolah setelah lulus juga dapat disebabkan keinginan untuk bertemu dengan teman atau guru di sekolah tersebut, bukan karena ikatan dengan sekolahnya.

Berdasarkan data tambahan dari kuesioner, peneliti mendapatkan hasil bahwa terdapat cukup banyak variasi perilaku perundungan yang terjadi. Selain perilaku perundungan yang dapat dikategorikan sebagai bentuk perundungan verbal, relasional atau tidak langsung dan fisik, terdapat pula perilaku yang memiliki kemungkinan sebagai percampuran antara ketiga bentuk perundungan tersebut. Perilaku yang dimaksud adalah memalak uang atau barang, melabrak, senioritas dan perilaku lain yang tidak disebutkan responden yang terjadi pada masa orientasi siswa. Berdasarkan pengalaman, peneliti dapat mengasumsikan bahwa perilaku-perilaku tersebut dapat dilakukan dengan menggabungkan bentuk-bentuk perundungan yang ada. Misalnya perilaku memalak, bukan hanya dilakukan dengan tekanan verbal namun juga dapat diikuti dengan tekanan secara fisik dan relasional. 


\section{SIMPULAN DAN IMPLIKASI}

Berdasarkan analisis hasil diperoleh kesimpulan bahwa semakin tinggi place attachment atau ikatan terhadap sekolah menyebabkan semakin kuatnya hubungan antara perundungan yang terjadi di sekolah dan school well-being atau kebahagiaan siswa di sekolah tersebut. Ikatan yang tinggi terhadap sekolah dapat mengurangi dampak negatif perundungan yang terjadi di sekolah, sehingga siswa akan tetap dapat merasa nyaman dan bahagia di sekolah.

Implikasi dari simpulan tersebut, peneliti menyarankan beberapa hal untuk penelitian selanjutnya, yaitu: (1) Pemilihan responden disesuaikan dengan kebutuhan penelitian, dimana perlu dipertimbangkan ingatan responden tentang pengalamannya saat SMA yang dapat mempengaruhi penilaian responden tentang place attachment. Semakin dekat pengambilan data dengan pengalaman aktual responden maka respon yang diberikan akan semakin sesuai, lebih detail dan menghindari bias, (2) Hasil penelitian yang menyatakan bahwa place attachment memoderasi hubungan perundungan dan school well being menunjukkan bahwa dengan membentuk ikatan dengan sekolah melalui peningkatkan fungsi sekolah, seperti peningkatan kurikulum dan proses pembelajaran atau menanamkan visi misi sekolah dalam setiap kegiatan di sekolah akan membuat siswa sadar akan dampak perundungan pada kebahagiaannya di sekolah. Melalui tumbuhnya kesadaran tersebut siswa akan dapat lebih mudah didorong bersama-sama menanggulangi perundungan yang terjadi, (3) Selain berupaya untuk menurunkan tingkat perundungan, sekolah dapat berupaya agar sekolah menjadi rumah kedua bagi siswa, sehingga ia akan tetap merasa nyaman bersekolah. Dengan demikian diharapkan bahwa mereka tetap akan belajar dengan baik walaupun perundungan masih terjadi. (4) Hasil penelitian lainnya mengungkapkan bahwa masih banyaknya perundungan yang terjadi di lingkungan sekolah dan daerah sekitar sekolah. Hal tersebut membutuhkan perhatian lebih dari pihak sekolah dan pihak keluarga untuk dapat lebih memberikan pengawasan sebagai tindakan preventif pada perilaku perundungan yang kemungkinan terjadi. Semakin sedikit perilaku perundungan yang terjadi di sekolah dapat meningkatkan rasa aman siswa di sekolah sehingga dapat meningkatkan rasa nyaman di sekolah.

\section{REFERENSI}

Amini, Y. S. J. (2008). Bullying: Mengatasi kekerasan di sekolah dan lingkungan sekitar anak. Grasindo

Bandyopadhyay, S., Cornell, D. G., \& Konold, T. R. (2009). Validity of three school climate scales to assess bullying, aggressive attitudes, and help seeking. School Psychology Review, 38(3), 338. 
Beaudoin, H., \& Roberge, G. (2015). Student perceptions of school climate and lived bullying behaviours. Procedia-Social and Behavioral Sciences, 174, 321-330.

Bronfenbrenner, U. (2009). The ecology of human development. Harvard university press.

Brown, B. B., \& Perkins, D. D. (1992). Disruptions in place attachment. In Place Attachment (pp. 279-304). Springer, Boston, MA.

Brown, B. B., Perkins, D. D., \& Brown, G. (2004). Incivilities, place attachment and crime: Block and individual effects. Journal of environmental psychology, 24(3), 359-371.

Caprara, G. V., Kanacri, B. P. L., Gerbino, M., Zuffiano, A., Alessandri, G., Vecchio, G., ... \& Bridglall, B. (2014). Positive effects of promoting prosocial behavior in early adolescence: Evidence from a school-based intervention. International Journal of Behavioral Development, 38(4), 386-396

Craig, W., Harel-Fisch, Y., Fogel-Grinvald, H., Dostaler, S., Hetland, J., Simons-Morton, B., ... \& Pickett, W. (2009). A cross-national profile of bullying and victimization among adolescents in 40 countries. International journal of public health, 54(2), 216-224.

Espelage, D. L., Low, S. K., \& Jimerson, S. R. (2014). Understanding school climate, aggression, peer victimization, and bully perpetration: Contemporary science, practice, and policy. School psychology quarterly, 29(3), 233

Forero, R., McLellan, L., Rissel, C., \& Bauman, A. (1999). Bullying behaviour and psychosocial health among school students in New South Wales, Australia: cross sectional survey. Bmj, 319(7206), 344-348

Hayes, A. F. (2013). Mediation, moderation, and conditional process analysis. Introduction to Mediation, Moderation, and Conditional Process Analysis: A Regression-Based Approach edn. New York: Guilford Publications, $1-20$.

Haynes, N. M., Emmons, C., \& Ben-Avie, M. (1997). School climate as a factor in student adjustment and achievement. Journal of educational and psychological consultation, 8(3), 321-329.

Inalhan, G., \& Finch, E. (2004). Place attachment and sense of belonging.Facilities, 22(5/6), 120-128.

Konu, A. Rimpela, M. (2002). Well-being in Schools: A Conceptual Model. Oxford University. 
Kumar, R. (2005). Research methodology : A step-by-step guide for beginners. London : SAGE Publications

Kumar, R. O'Malley, P.M., Johnston, L.D. (2008). Association Between Physical Environment of Secondary Schools and Student Problem Behavior. Journals of Environment and Behavior.

Olweus, D. (1994). Bullying at school: basic facts and effects of a school based intervention program. Journal of child psychology and psychiatry, 35(7), 11711190.

Manzo, L. C. (2003). Beyond house and haven: toward a revisioning of emotional relationships with places. Journal of environmental psychology, 23(1), 47-61.

Nansel, T. R., Overpeck, M., Pilla, R. S., Ruan, W. J., Simons-Morton, B., \& Scheidt, P. (2001). Bullying behaviors among US youth: Prevalence and association with psychosocial adjustment. Journal of the American Medical Association, 285(16), 2094-2100.

Rigby, K. (2007). Bulllying in Schools: and what to do about it. ACER Press

Rigby, K. (2011). The Method of Shared Concern: A positive approach to bullying in schools. ACER Press

Rubinstein, R. I., \& Parmelee, P. A. (1992). Attachment to place and the representation of the life course by the elderly. In Place attachment (pp. 139-163). Springer, Boston, MA.

Scheithauer, H. dkk. (2006). Physical, Verbal, and Relational Forms of Bullying Among German Students: Age Trends, Gender Differences, and Correlates. Aggressive Behavior.

Schreyer, R., Jacobs, G. R., \& White, R. G. (1981). Environmental meaning as a determinant of spatial behaviour in recreation. In Proceedings of Applied Geography Conferences, Volume 4. (pp. 294-300). Department of Geography, State University of New York.

Shumaker, S. A., \& Taylor, R. B. (1983). Toward a clarification of people-place relationships: A model of attachment to place. Environmental psychology: Directions and perspectives, 2, 19-25.

Smith, P. K., Cowie, H., Olafsson, R. F., \& Liefooghe, A. P. (2002). Definitions of bullying: A comparison of terms used, and age and gender differences, in a Fourteen-Country international comparison. Child development, 73(4), 1119-1133. 
Stedman, R. C. (2002). Toward a social psychology of place: Predicting behavior from place-based cognitions, attitude, and identity. Environment and behavior, 34(5), 561-581.

Stokols, D., \& Shumaker, S. A. (1982). The Psychological Context of Residential Mobility and Weil-Being. Journal of Social Issues, 38(3), 149-171.

Suldo, S. M., Thalji-Raitano, A., Hasemeyer, M., Gelley, C. D., \& Hoy, B. (2013). Understanding middle school students life satisfaction: Does school climate matter?. Applied research in quality of life, 8(2), 169-182.

Williams, D.R. Roggenbuck, J.W. (1989). Measuring Place Attachment: Some Preliminary Result. Virginia Polyechnic Institute and State University

Williams, D. R., Patterson, M. E., Roggenbuck, J. W., \& Watson, A. E. (1992). Beyond the commodity metaphor: Examining emotional and symbolic attachment to place. Leisure sciences, 14(1), 29-46.

Wilson, D. (2004). The interface of school climate and school connectedness and relationships with aggression and victimization. Journal of school health, 74(7), 293-299

Woods, N. E. (2006). Place Attachment, Place-identity, Self-formation, and Imagination: A Narrative Construction. Doctoral dissertation. Alliant International University, California School of Professional Psychology, San Diego. 


\title{
AVOIDANCE COPING, CONTINGENT SELF-ESTEEM DAN BELANJA KOMPULSIF
}

\author{
Djudiyah \\ Fakultas Psikologi Universitas Muhammadiyah Malang \\ djudiyah@umm.ac.id
}

\begin{abstract}
Abstrak. Membanjirnya iklan produk fashion di berbagai media dan mudahnya mendapatkan produk pakaian, membuat keputusan berbelanja anak-anak muda lebih didasarkan pada aspek emosi. Keputusan berbelanja seringkali dimaksudkan untuk mendapatkan gengsi atau penghargaan dari orang lain dapat mendorong mereka melakukan belanja kompulsif. Penelitian ini bertujuan untuk mengetahui peran avoidance coping dalam memediasi hubungan antara contingent self-esteem dengan belanja kompulsif pakaian. Subjek penelitian ini berjumlah 276 mahasiswi Universitas Muhammadiyah Malang Angkatan 2018 yang diambil dengan teknik stratified sampling. Instrumen penelitian yang digunakan dalam proses pengumpulan data adalah: skala Contingent Self-esteem (CSE), skala Coping Respon Inventoty (CRI) dan skala belanja kompulsif pakaian. Analisis data dilakukan dengan metode Mediation Analysis dari Hyes menunjukkan bahwa avoidance coping mampu memediasi hubungan antara contingent self-esteem dengan belanja kompulsif yang ditunjukkan dengan $\mathrm{B}=0.322$; dengan $\mathrm{p}=0.006(<0.01)$.
\end{abstract}

Kata Kunci: avoidance coping, contingent self-esteem, belanja kompulsif

\begin{abstract}
The flood of advertisements on fashion products in various media and the ease of getting clothing products, makes the decision to shop for young people more based on emotional aspects. Shopping decisions are often meant to get prestige or appreciation from others, which can encourage them to do compulsive shopping. This study aims to determine the role of avoidance coping in mediating the relationship between contingent self-esteem and compulsive shopping for clothing. The subject of this study amounted to 276 female students at the University of Muhammadiyah Malang Force 2018 taken by stratified sampling technique. The measures used were: Contingent Self-esteem (CSE) scale, Inventory Response Coping scale (CRI) and clothing compulsive shopping scale. Data analysis was performed by the Mediation Analysis method from Hyes showed that avoidance coping was able to mediate the relationship between contingent self-esteem and compulsive spending as indicated by $B=0.322$; with $p=0.006 \quad(<0.01)$.
\end{abstract}

Keywords: avoidance coping, contingent self-esteem, compulsive shopping 
Perkembangan teknologi informasi yang sangat pesat di abad 21 ini berdampak pada semua aktivitas kehidupan manusia, salah satu diantaranya berpengaruh pada perilaku kosumen. Konsumen semakin mudah mendapatkan informasi tentang produk maupun jasa yang dibutuhkan. Melalui internet (toko-toko online) konsumen dapat mencari produk yang diinginkan dan dapat membanding-bandingkan produk atau jasa satu dengan produk atau jasa lainnya. Pakaian merupakan salah poduk yang menjadi minat anak-anak muda, karena mereka sangat peduli dengan penampilannya (Hurlock, 2004). Produsen mampu menawarkan berbagai produk pakaian dikalangan anak-anak muda generasi $\mathrm{Y}$ dan $\mathrm{Z}$ atau generasi melenial dengan beaya murah dan dapat menjangkau semua segmen pasarnya tanpa harus dibebani sewa toko. Hal ini diperkuat riset yang dilakukan Nielsen pada tahun 2017 menunjukkan bahwa jaringan internet yang diakses melalui smartphone merupakan media sosial yang banyak diakses anak-anak muda (Priyadana, 2018).

Maraknya tayangan iklan produk pakaian di internet dan tingginya intensitas anak-anak muda mengakses situs-situs di internet terutama produk pakaian dapat berpengaruh pada pembelanjaan pakaian yang dilakukan. Apalagi anak-anak muda generasi Y dan Z ini tidak pernah lepas dari internet dan smarthphone dalam kehidupan kesehariannya (Shareef, Dwivedi \& Kumar, 2016). Anak-anak muda dengan self-esteem tinggi mampu menilai iklan yang mereka lihat secara proporsional. Mereka mampu berpikir rasional sebelum memutuskan untuk melakukan proses pembelian. Namun bagi anakanak muda yang memiliki self-esteem rendah akan menilai iklan yang dilihat sebagai pembanding penampilannya. Anak-anak muda dengan self esteem rendah menginginkan dirinya sebagaimana penampilan bintang iklan yang dilihatnya (Rath, Bay, Petrizzi \& Gill, 2015).

Pembelian produk pakaian yang dilakukan anak-anak muda dengan self-esteem rendah lebih didorong untuk mendapatkan penampilan diri yang ideal agar citra diri dapat positif (Rath, et al., 2015). Keputusan membeli bukan karena kebutuhan, tapi lebih didasari oleh keinginan sesaat, sekedar mengikuti tren atau menjaga gengsi (Setiana, 2013). Mereka seringkali berbelanja produk di luar jangkauannya atau kemampuan keuangannya, berbelanja produk yang kurang memiliki kegunaan, produk-produk mahal serta suka mengumpulkan produk. Hal ini disebabkan karena ada perasaan bangga ketika mampu memiliki barang yang orang lain belum tentu memilikinya, tidak ingin kalah saingan dengan teman kuliah maupun dengan teman kosnya (Farida, 2011). Pembelanjaan ini biasa disebut dengan belanja kompulsif (Horvath, Adiguzel \& Herk, 2013).

Beberapa riset terdahulu menemukan bahwa anak-anak muda dengan self esteem rendah cenderung melakukan belanja kompulsif (Ridgway, Kukar-Kennay, \& Monroe, 2006; Ureta, 2007; Benson, Dittmar \& Wolfsohn, 2010; Ergin, 2010; Lejoyeox, et al., 2011; Lo, \& Harvey, 2012; Horvath, Adiguzel \& Herk, 2013; Mangestuti, 2014). Anak-anak muda dengan self-esteem rendah merasa bahwa dirinya tidak kompeten dan berharga. Mereka berusaha menemukan rasa berharga atau rasa bermakna dari penerimaan, cinta dan persetujuan orang di sekitarnya terutama dari teman sebayanya (peer group). Mereka berusaha menyeragamkan diri dengan harapan orang sekitarnya untuk mendapatkan rasa berharga, bermakna atau cinta dari orang lain. Perasaan berharga yang bersumber dari orang lain atau eksternal ini juga disebut dengan contingent self-esteem tinggi (Johnson 
\& Blom, 2007). Mereka merasa berharga atau merasa berarti ketika mampu memenuhi harapan orang lain terutama peer groupnya.

Riset Biolcati (2017) pada individu yang berusia 18-60 tahun menemukan bahwa individu dengan contingent self-esteem tinggi cenderung melakukan belanja kompulsif dibanding dengan individu dengan contingent self-esteem rendah. Penelitian ini sebenarnya hampir sama dengan penelitian terdahulu yang mencoba mengkaji antara self-esteem dengan belanja kompulsif (Liu \& Laird, 2008; Mangestuti, 2014). Individu dengan self-esteem rendah atau individu dengan contingent self-esteem tinggi cenderung melakukan belanja kompulsif. Hal ini disebabkan karena sumber perasaan berharga atau bermakna tergantung pada penerimaan, cinta atau persetujuan orang lain.

Patrick, Neighbors \& Knee (2004) dan Shrestha (2013) menemukan bahwa mahasiswi dengan self-esteem rendah lebih suka membandingkan penampilannya dengan model iklan, mengalami lebih besar pengurangan afek positif, lebih banyak mengamati dan mengevaluasi kondisi fisik (body) nya dan malu pada beberapa kondisi. Mereka cenderung menggunakan avoidance coping dalam mengatasi permasalahannya (Undheim \& Sund, 2017; McNicol \& Thorsteinsson, 2017). Ketika mereka merasa kurang mendapatkan penghargaan dari teman, mereka berusaha menghindar untuk mereduksi kecemasan yang dialaminya (McNicol \& Thorsteinsson, 2017).

Riset Servidioa, Ambra \& Bocab (2018) dan McNicol \& Thorsteinsson (2017) menemukan bahwa mahasiswa dengan harga diri rendah atau memiliki contingent self-esteem tinggi rentan mengalami adiksi internet. Strategi avoidance coping mampu memediasi hubungan antara self-esteem dengan adiksi internet. Meski riset ini tentang adiksi internet, namun pada prinsipnya konsep teori yang digunakan adalah terori obsessive compulsive. Berdasarkan hasil riset ini peneliti berasumsi bahwa avoidance coping yang dimiliki individu dapat memperkuat hubungan antara contingent self-esteem dengan belanja kompulsif pada mahasiswa.

Riset yang dilakukan pada 300 mahasiswa Universitas Italia menemukan bahwa ada hubungan negatif antara harga diri dengan resiko adiksi internet. Strategi coping menghindar mampu memediasi hubungan antara self-esteem dengan resiko adiksi internet (Servidioa, Ambra Gentileb, \& Bocab, 2018). Berdasarkan temuan ini, peneliti berasumsi bahwa ada hubungan positif antara contingent self-esteem dengan belanja kompulsif pakaian dengan strategi coping menghindar (avoidance coping) sebagai variabel mediasi. Anakanak muda dengan contingent self-esteem tinggi memiliki resiko tinggi untuk melakukan belanja kompulsif pakaian, terutama ketika mereka memiliki intensitas tinggi dalam menggunakan strategi coping menghindar ketika dihadapkan pada permasalahan.

Beberapa penelitian terdahulu menemukan bahwa anak-anak muda yang suka berbelanja secara kompulsif kurang termotivasi dengan penyelesaian studinya. Mereka asyik dengan berbelanja, browshing produk di toko online dan kurang tertarik dengan aktivitas yang melibatkan tantangan intelektual, hobi, memelihara serta meningkatkan kreativitasnya. Banyak waktunya digunakan untuk mencari uang untuk berbelanja secara kompulsif dibanding dengan upaya pengembangan dirinya sehingga mengganggu proses pencapaian masa depannya. Mereka juga cenderung mengalami kekosongan spiritual 
sebagai akibat dari overshopping yang dilakukannya. Mereka beresiko kehilangan hubungan dekat dengan keluarga, masyarakat dan alam (Kasser, 2002; Schwartz, 2004). Kebanyakan dari mereka memiliki kesadaran rendah pada pertumbuhan being more (Benson, Dittmar \& Wolfsohn, 2010).

Belanja kompulsif merupakan dorongan yang sangat kuat untuk berbelanja yang tidak dapat ditahan, kehilangan banyak kontrol dalam perilaku berbelanja serta terus menerus melakukan pembelanjaan meskipun akibatnya merugikan atau berlawanan dengan kehidupan personal, sosial, kehidupan pekerjaannya maupun hutang finansial (Dittmar, 2004; 2005). Belanja kompulsif dilakukan untuk menunjukkan identitas dirinya pada orang lain serta untuk mengurangi kesenjangan antara self yang riil dan self yang ideal. Dengan demikian, belanja kompulsif dipertimbangkan sebagai gangguan mengontrol dorongan (Dittmar, 2004; Billieux, et al., 2008).

Menurut Dittmar (2004; 2005) ada tiga dimensi belanja kompulsif, yaitu:

1) Dorongan yang sangat kuat

Dorongan yang sangat kuat merupakan dorongan atau keinginan yang sangat kuat untuk melakukan pembelanjaan yang hadir terus menerus dalam pikiran.

2) Kehilangan kontrol

Kehilangan kontrol merupakan ketidakmampuan menghentikan keinginan dan dorongan yang sangat kuat untuk berbelanja.

3) Konsekwensi yang merugikan.

Belanja kompulsif mengakibatkan kerugian yang bersifat personal, sosial, pekerjaan dan hutang finansial.

Ureta (2007) menyatakan ada beberapa faktor yang menjadi penyebab terjadinya belanja kompulsif, yaitu:

1) Ketidakstabilas emosi (emotional instability)

Individu yang memiliki emosi yang tidak stabil mudah terpengaruh oleh lingkungan sekitarnya. Individu akan mencari cara untuk meredam emosinya dengan cara melakukan pembelanjaan kompulsif

2) Kepribadian

Individu dengan self-esteem rendah atau memiliki inferriority feeling tinggi cenderung melakukan belanja kompulsif.

4) Nilai-nilai (values) yang diinternalisasi individu.

Individu dengan nilai materialistic tinggi cenderung melakukan belanja impulsif, karena tujuan hidup dan ukuran kesuksesan adalah banyaknya materi yang dimilikinya.

5) Ketidakmampuan mengontrol diri

Individu yang tidak mampu mengontrol dirinya cenderung melakukan belanja kompulsif. Mereka mudah terbujuk oleh bujukan iklan atau pengaruh model.

6) Latarbelakang keluarga.

Keluarga yang menjadikan standar kesuksesan dalam hidupnya adalah materi dapat membuat anak-anaknya juga berorientasi pada materi, sehingga mereka seringkali melakukan pembelanjaan kompulsif. Anak-anak akan memodel orang tuanya dalam melakukan pembelanjaan secara kompulsif. 
7) Krisis hubungan suami istri

Hubungan suami istri yang tidak harmonis yang dialami dalam kurun waktu yang lama dapat menghasilkan distress psikologis. Sebagai akibatnya istri akan mereduksi ketegangan yang dialami dengan melakukan pembelanjaan yang berlebihan.

Contingent self-esteem didefinisikan sebagai interpretasi seseorang bahwa dirinya berharga. Perasaan berharga ini tergantung pada penilaian seseorang tentang keberhasilan dan kegagalan yang bersumber dari faktor eksternal, misalnya: keinginan untuk dicintai orang lain, keinginan diterima oleh orang lain, menginginkan diri sempurna (perfect pada diri sendiri), keinginan untuk memenuhi harapan orang lain (Johnson \& Blom, 2007).

Perasaan berharga pada individu dengan contingent self-esteem tinggi diperoleh tergantung pada sejauhmana orang lain atau kelompok memberikan persetujuan terhadap keberhasilan yang dicapai. Dengan demikian, dapat dikatakan bahwa perasaan kompeten pada diri mereka terbentuk dengan persyaratan tertentu (unconditional competence) dari lingkungan sosialnya. Sebagai akibatnya individu dengan contingent self-esteem tinggi sering merasa frustrasi, mengkritik diri sendiri dan berjuang untuk mendapatkan perasaan kompeten dari orang lain. Individu berusaha berjuang untuk mendapatkan cinta bersyarat, takut ditolak dan patuh pada standar orang lain atau kelompok (Johnson \& Blom, 2007).

Menurut Johnson \& Blom (2007) ada 2 dimensi contingent self-esteem ada 2, yaitu:

1) Kompeten (competence base self-esteem)

Kompeten diartikan sebagai merasa mampu atau merasa mendapatkan prestasi, status maupun kesempurnaan (perfect) dalam hubungan interpersonal. Hal ini membuat orang mengkritik diri sendiri, ambisius, mengontol atau agresif dalam hubungan interpersonal.

a. Contingent upon competence

Merasa kompeten, berprestasi, mendapatkan status tergantung pada penilaian orang lain

b. Self-critical

Mengkritik diri sendiri dan mengharapkan diri sempurna

2) Hubungan dengan orang lain (relations based self-esteem)

Kecenderungan individu untuk mendukung menenteramkan hati terus menerus untuk kelekatan pada orang lain disamping perasaan berguna atau bermanfaat.

a. Rejection

Menghindari penolakan orang lain

b. Contingent upon love

Tergantung dengan cinta dari orang lain

c. Compliance

Patuh pada harapan orang lain.

Coping didefinisikan sebagai usaha kognitif dan perilaku yang dilakukan terus menerus untuk mengelola tuntutan lingkungan eksternal maupun internal yang spesifik yang dinilai melebihi sumberdaya seseorang (Lazarus, 1993). Individu berusaha memberikan 
respon baik secara kognitif maupun perilaku terus menerus ketika dihadapkan pada tuntutan lingkungan (stressor) yang berada diatas kapasitas yang dimilikinya.

Beberapa ahli memiliki pandangan yang berbeda tentang strategi coping atau cara orang merespon tuntutan (stressor) lingkungannya. Lazarus (1993) membagi strategi coping menjadi 8 macam, yaitu : confrontive coping, distancing, self-controlling, seeking social support, accepting responsibility, escape-avoidance, planful problem-solving serta positive reappraisal. Setelah dikaji ulang ternyata ke delapan macam strategi coping ini dapat diklasifikasikan menjadi 2 strategi, yaitu: problem focus coping dan emotion focus coping.

Moos (2004) menyatakan bahwa pada strategi problem focus coping, individu berusaha secara kognitif maupun perilaku untuk mengatasi persoalan atau tuntutan kehidupan yang dialami melebihi kapasitas yang dimilikinya. Namun pada emotion focus coping, individu berusaha untuk memberikan respon baik secara kognitif maupun perilaku dengan cara berpikir menjauh dari stressor dan sebagai implikasinya berusaha mengelola stressor berdasar emosinya. Berdasarkan pandangan ini, Moos (2004) membagi coping menjadi 2 macam, yaitu: approach respon an avoidance respon.

Moos (2004) membagi strategi coping menjadi 2 yaitu, approach coping dan avoidance coping, dimana tiap-tiap strategi coping memiliki dua dimensi yaitu:

1) Approach coping responses

a. Kognitif.

Individu berusaha menganalisis secara logis terhadap persoalan hidup yang dialaminya dan berusaha menilainya kembali secara positif.

b. Behavioral

Individu berusaha mencari petunjuk dan support untuk melakukan problem solving

2) Avoiding coping responses

a. Kognitif

Individu berusaha menghindar secara kognitif atau menolak untuk berpikir logis terhadap persoalan yang dialami dan menerimanya dengan pasrah (pengunduran diri).

b. Behavioral

Individu berusaha mencari alternatif reward dan mengeluarkan/menyalurkan emosi

Meskipun Moos (2004) menyusun skala strategi coping menjadi 2, namun pada penelitian ini hanya digunakan item-tem yang mengukur avoidance coping saja dengan pertimbangan bahwa tujuan dari penelitian ini hanya ingin mengetahui avoidance coping.

Teman sebaya (peer group) berpengaruh besar terhadap kehidupan anak-anak muda (Hurlock, 2004). Anak-anak muda cenderung membandingkan diri dengan peer groupnya, karena peer merupakan sumber norma, sikap dan nilai personal bagi mereka (Childers \& Rao, 1992). Studi menunjukkan bahwa komunikasi atau kedekatan hubungan interpersonal dengan peer berpengaruh pada motivasi sosial anak-anak muda 
untuk mengkonsumsi serta menggunakan peer sebagai rujukan dalam memilih produk (Liu \& Laird, 2008; Lee \& Park, 2008).

Anak-anak muda yang cenderung membandingkan dirinya dengan orang lain terutama peer groupnya akan tidak menguntungkan bagi perkembangan self-esteemnya (Chan \& Zhang, 2007). Mereka hanya akan merasa berharga ketika mereka berperilaku sesuai dengan harapan kelompoknya. Mereka lebih rentan dipengaruhi oleh peer karena mereka sedang mencari definisi tentang diri sebagai individu atau sedang melakukan eksplorasi diri untuk menemukan identitas diri (Sharma, Raciti, O’Hara \& Reinhard, 2013). Rendahnya self-esteem ini juga dapat disebut dengan contingent self-esteem tinggi. Mereka hanya akan merasa berharga ketika mereka mampu memenuhi harapan atau menyeragamkan diri dengan standar atau keinginan orang lain atau kelompoknya (Biolcati, 2017).

Anak-anak muda dengan contingent self-esteem tinggi akan merasa berharga ketika mereka mampu mendapatkan prestasi, status atau mampu berpenampilan sempurna (perfect) berdasarkan standar perilaku orang lain atau teman sebayanya. Mereka khawatir mendapatkan penolakan orang lain, mengharapkan cinta dari orang lain, sehingga mereka cenderung patuh dengan apa yang diharapkan oleh kelompoknya. Dengan demikian, anak-anak muda dengan contingent self-esteem tinggi lebih dipengaruhi oleh faktor yang bersifat eksternal. Namun sebaliknya, anak-anak muda dengan contingent self-esteem rendah akan merasa berharga ketika mereka mampu mengembangkan potensinya. Mereka mampu mengevaluasi dirinya secara objektif sehingga mereka mampu menerima dirinya secara proporsional. Dengan demikian, anak-anak muda dengan contingent selfesteem rendah lebih dipengaruhi oleh faktor yang bersifat internal dalam mendapatkan perasaan berharganya (Biolcati, 2017).

Anak-anak muda memiliki perhatian besar dengan penampilannya. Penampilan yang menarik dapat mensupport mereka dalam berinteraksi dengan orang lain terutama peer groupnya (Hurloock, 2004). Mereka cenderung berafiliasi dengan teman yang memiliki atribut yang sama atau memiliki beberapa kesamaan (Ryan, 2001). Mereka berusaha menggunakan opini teman dalam memutuskan pembelanjaan (Lee \& Park, 2008). Mereka berusaha untuk menggunakan standar peer groupnya sebagai acuan dalam berbelanja terutama pada anak-anak muda dengan contingent self-esteem tinggi. Mereka berusaha berbelanja produk sesuai dengan standar kelompoknya, mengevaluasi dirinya secara kritis, ingin tampil perfect dalam setiap situasi. Hal ini dimaksudkan agar dirinya mendapatkan perhatian, penerimaan, penghargaan dan cinta dari orang lain (Johnson \& Blom, 2007; Biolcati, 2017). Dengan demikian, anak-anak muda dengan contingent selfesteem tinggi mengaharapkan dirinya senantiasa berpenampilan yang atraktif, mendapatkan penerimaan, memiliki power, serta ingin selalu sukses dalam interaksi sosial (Patrick, Neighbors \& Knee, 2004). Harapan-harapan terhadap diri yang demikian ini akan mendorong mereka melakukan belanja kompulsif (Mangestuti, 2014; Biolcati, 2017) baik melalui toko konvensional maupun toko online (Dittmar, Long \& Bond, 2007). 
Anak-anak muda yang memiliki strategi avoidance coping tinggi cenderung menjauhkan diri dari pikiran dan perilakunya untuk mengatasi tuntutan lingkungan yang menekan dirinya (Moos, 2004). Mereka berusaha mencari aktivitas pengganti, menarik diri dan menjauhi sumber stress, pasif dalam merespon sumber stress, merasa tidak berdaya dan tidak memiliki harapan dengan permasalahan yang dialaminya (Lazarus, 1993; OteroLopes \& Villardefracos, 2014 ;Dziurzyńska, Pawłowska \& Potembska, 2016). Individu cenderung melakukan belanja kompulsif sebagai upaya untuk menjauhkan diri dari tuntutan lingkungan sekitarnya yang menekan serta mengalihkan pikiran untuk menjauhkan diri dari stressor kehidupan (Otero-Lopes \& Villardefracos, 2014).

Anak-anak muda dengan contingent self-esteem tinggi cenderung menggunakan avoidance coping dalam mengatasi persoalan yang dialaminya (Shrestha, 2013). Mereka cenderung membanding-bandingkan penampilannya dengan teman-temannya. Ketika mereka merasa tidak mampu menampilkan dirinya secara atraktif, mereka akan merasa cemas, merasa takut ditolak orang lain terutama teman-temannya (Crocker \& Park, 2004). Perasaan negatif yang dialami ini membuat mereka menarik diri (withdrawl) dari teman-temannya, menerima dengan tidak berdaya (Lazarus, 1993) atau melakukan pembelanjaan kompulsif. Belanja kompulsif dimaksudkan sebagai upaya untuk mengatasi persoalan yang dialaminya (Otero-Lopes \& Villardefracos, 2014) atau sebagai cara untuk mengatasi kecemasan dan perasaan tertekan (stress) yang dialami (Dziurzyńska, Pawłowska \& Potembska, 2016). Mereka memiliki motivasi tinggi untuk menyeragamkan diri dengan teman-temannya dalam berpakaian. Mereka berusaha untuk mendapatkan produk pakaian yang sedang trend dan dipakai teman-temannya. Dengan demikian, anak-anak muda dengan contingent self-esteem tinggi cenderung melakukan belanja kompulsif, apalagi bila mereka juga memiliki strategi avoidance coping tinggi

Berdasarkan paparan diatas dapat disimpulkan bahwa anak-anak muda dengan contingent self-esteem tinggi mengharapkan dirinya selalu kompeten dan tampil perfect dalam segala situasi. Mereka berusaha memenuhi harapan atau tuntutan peer groupnya, khususnya dalam berpakaian. Mereka berusaha keras mengikuti perkembangan mode pakaian yang sedang trend. Mereka akan mencari informasi tentang produk pakaian baik melalui toko konvensional maupun online dan melakukan belanja kompulsif. Hal ini dimaksudkan agar mereka mendapatkan pujian dan penerimaan dari orang lain, memiliki kekuasaan (power), selalu tampil sukses dalam segala situasi, sehingga mereka merasa berharga. Perilaku berbelanja semacam ini akan membentuk pola dan akan dilakukan kembali ketika mereka dihadapkan pada stressor kehidupan lain dimasa yang akan datang. Apalagi ketika anak-anak muda memiliki strategi coping avoidance tinggi, maka mereka juga akan semakin tinggi belanja kompulsifnya. Belanja kompulsif pakaian dimaksudkan untuk menjauhkan diri dari pikiran dan perilaku dari tuntutan lingkungann yang menekannya. Belanja kompulsif pakaian dijadikan sebagai aktivitas pengganti yang menyenangkan.

Penelitian ini memiliki tiga tujuan penelitian, yaitu: (1) untuk mengetahui hubungan antara contingent self-esteem dengan belanja kompulsif; (2) untuk mengetahui hubungan antara contingent self-esteem dengan avoidance coping; (3) untuk mengetahui Avoidance coping memediasi hubungan antara contingent self-esteem dengan belanja kompulsif. 
Penelitian ini bermanfaat untuk mengembangkan teori psikologi konsumen yang masih relatif terbatas, khususnya pengembangan teori belanja kompulsif. Hasil penelitian ini juga dapat digunakan sebagai dasar untuk melakukan upaya prevensi maupun kurasi terhadap fenomena belanja kompulsif, khususnya dikalangan mahasiswi.

\section{METODE PENELITIAN}

Penelitian ini merupakan penelitian kuantitatif korelasional (Suryabrata, 2012). Peneliti ingin mengetahui hubungan antara contingent self-esteem dengan belanja kompulsif pakaian yang dimediasi oleh avoidance coping.

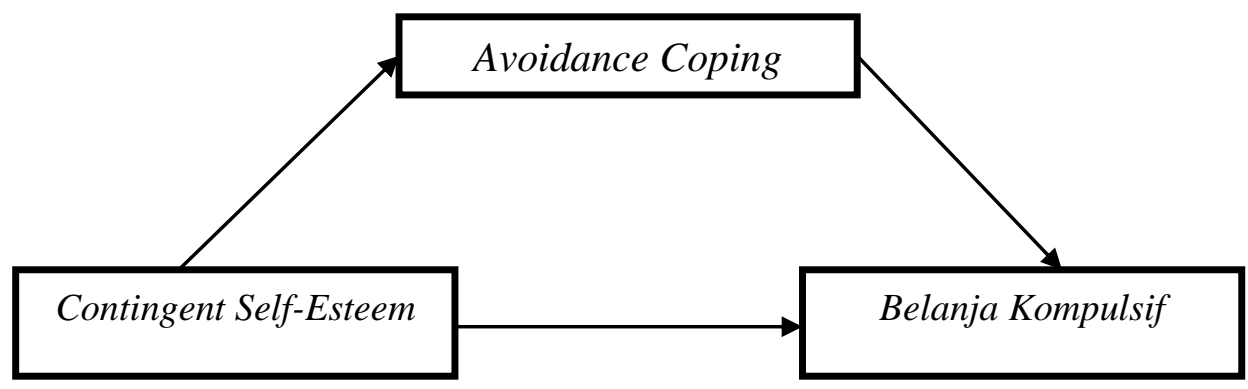

Gambar 1. Desain Penelitian

Populasi pada penelitian ini adalah mahasiswi Universitas Muhammadiyah Malang Angkatan Tahun 2018. Sedangkan sampel pada penelitian ini berjumlah 276 mahasiswi yang diambil dengan teknik stratified sampling (Neuman, 2000).

Terdapat tiga variabel pada penelitian ini yaitu: contingent self-esteem sebagai variabel bebas, avoidance coping sebagai variabel mediasi dan belanja kompulsif pakaian sebagai variabel tergantung. Metode pengumpul data pada penelitian ini adalah skala. Ada 3 skala yang digunakan dalam penelitian ini yaitu, Skala Contingent Self-Esteem (CSE), skala avoidance coping (CRI), serta skala belanja kompulsif.

Skala Contingent Self-Esteem (CSE) disusun oleh Johnson dan Blom (2007). Ada 2 aspek atau dimensi contingent self-esteem yaitu competence based self-esteem dan relation based self-esteem. Skala contingent self-esteem disusun sebanyak 26 item, yang terdiri dari 12 item untuk aspek competence based self-esteem dan 14 item untuk aspek relation based self-esteem. Uji coba skala contingent self-esteem yang dilakukan peneliti pada 91 mahasiswa Fakultas Psikologi Universitas Muhammadiyah Malang, angkatan 2017 menemukan bahwa dari 26 item, ada 22 item yang dinyatakan valid dan ada 4 item yang dinyatakan tidak valid. Angka validitasnya bergerak dari $r=0.347-0.661$ dan koefisien reliabilitas sebesar $\alpha=0.900$. Dua puluh tiga item yang dinyatakan valid inilah yang digunakan untuk penelitian.

Avoidance coping diukur menggunakan skala Coping Respon Inventory (CRI) yang disusun oleh Moos (2004) sebanyak 48 item. Ada 24 item untuk mengukur approach 
coping dan ada 14 item untuk mengukur avoidance coping. Uji coba skala avoidance coping yang dilakukan pada 91 mahasiswa Fakultas Psikologi Universitas Muhammadiyah Malang, Angkatan tahun 2017 menemukan bahwa dari 14 item, ada 11 item yang dinyatakan valid dan ada 3 item yang dinyatakan tidak valid. Angka validitasnya bergerak dari 0.325 sampai 0.573 dan koefisien reliabilitas sebesar $\alpha=$ 0.794. Sebelas item yang dinyatakan valid inilah yang akan digunakan untuk mengambil data penelitian. Skala contingent self-esteem dan avoidance coping disusun dalam bentuk skala Likert dengan lima alternatif jawaban, yaitu : Sangat Sesuai (SS), Sesuai (S), Cukup Sesuai (CS), Tidak Sesuai (TS) dan Sangat Tidak Sesuai (STS) (Azwar, 2012).

Skala belanja kompulsif disusun berdasar teori Dittmar (2005). Ada 3 aspek belanja kompulsif yaitu dorongan yang sangat kuat untuk melakukan pembelanjaan, dorongan berbelanja yang sulit dikendalikan dan konsekwensi yang merugikan. Skala ini disusun sebanyak 28 item dengan angka validitas bergerak dari 0.308 sampai 0.750 dengan koefisien reliabilitas sebesar $\alpha=0.902$. Skala belanja kompulsif pakaian disusun dalam bentuk skala Likert dengan lima alternatif jawaban, yaitu : Selalu (SL), Sering (S), Terkadang (KDG), Jarang (J) dan Tidak Pernah (TP).

Metode analisis data yang digunakan pada penelitian ini adalah Mediation Analysis dari Hyes. Metode ini dimaksudkan untuk mengetahui hubungan antara contingent selfesteem dengan belanja kompulsif pakaian dan avoidance coping dalam memediasi hubungan antara contingent self-esteem dengan belanja kompulsif pakaian. Analisis data pada penelitian ini dilakukan dengan bantuan program SPSS v.21.

\section{HASIL PENELITIAN}

Hasil uji hubungan antara contingent self-esteem dengan belanja kompulsif pakaian sebagaimana tabel berikut:

\section{Tabel 1.}

Hasil Uji Hubungan Antara Contingent Self-esteem Dengan Belanja Kompulsif Pakaian

\begin{tabular}{lcc}
\hline \multicolumn{1}{c}{ Model } & B & Sig. \\
\hline $\begin{array}{l}\text { Variabel X } \\
\text { terhadap Y }\end{array}$ & 0.686 & $0.000(\mathrm{p}<0.01)$ \\
\hline
\end{tabular}

Dari Tabel 1. menunjukkan terdapat hubungan positif yang sangat signifikan antara contingent self-esteem dengan belanja kompulsif pakaian pada mahasiswi yang ditunjukkan dengan $\mathrm{B}=0.686$, dengan $\mathrm{p}=0.000(<0.01)$. Dengan demikian, hipotesis yang menyatakan ada hubungan positif antara contingent self-esteem dengan belanja kompulsif pakaian pada penelitian ini, diterima. 
Tabel 2.

Hasil Uji Hubungan Antara Contingent Self-esteem Dengan Avoidance Coping

\begin{tabular}{ccc}
\hline Model & B & Sig. \\
\hline $\begin{array}{l}\text { Variabel X } \\
\text { terhadap M }\end{array}$ & 0.459 & $0.000(\mathrm{p}<0.01)$ \\
\hline
\end{tabular}

Tabel 2. menunjukkan terdapat hubungan positif yang sangat signifikan antara contingent self-esteem dengan coping menghindar (avoidance coping) yang ditunjukkan dengan $\mathrm{B}=0.459$; dengan $\mathrm{p}=0.000(<0.01)$. Artinya, semakin tinggi contingent self-esteem yang dimiliki mahasiswi maka mahasiswi memiliki kecenderungan untuk menggunakan coping menghindar ketika dihadapkan pada sebuah persoalan kehidupan.

Tabel 3.

Hasil Uji Hubungan Antara Contingent Self-esteem Dengan Belanja Kompulsif Pakaian yang Dimediasi oleh Avoidance Coping

\begin{tabular}{lcc}
\hline Model & B & Sig. \\
\hline Variabel X terhadap Y dan & 0.539 & $0.000(\mathrm{p}<0.01)$ \\
M & 0.322 & $0.000(\mathrm{p}<0.01)$ \\
\hline
\end{tabular}

Tabel di atas menunjukkan bahwa coping menghindar (avoidance coping) mampu memediasi hubungan antara contingent self-esteem dengan belanja kompulsif pakaian pada mahasiswi yang ditunjukkan dengan $\mathrm{B}=0.322$; dengan $\mathrm{p}=0.006(<0.01)$. Dengan demikian, hipotesis yang menyatakan bahwa avoidance coping mampu memediasi hubungan antara contingent self-esteem dengan belanja kompulsif pakaian pada mahasiswi, diterima.

\section{DISKUSI}

Hasil penelitian menunjukkan bahwa ada hubungan positif dan sangat signifikan antara contingent self-esteem dengan belanja kompulsif pakaian pada mahasiswi. Mahasiswi dengan contingent self-esteem tinggi memiliki kecenderungan tinggi untuk melakukan belanja kompulsif pakaian. Hasil penelitian ini mendukung hasil riset Mangestuti (2014) yang menemukan bahwa mahasiswa dengan self-esteem rendah cenderung melakukan belanja secara kompulsif. Mahasiswi dengan contingent self-esteem tinggi memiliki keinginan atau dorongan yang sangat kuat untuk mendapatkan penghargaan dari orangorang sekitarnya, karena perasaan berharganya sangat ditentukan oleh reaksi positif orang lain terhadap dirinya, khususnya penampilannya (appearance).

Riset Dittmar \& Drury (2000) menemukan bahwa wanita berbelanja lebih didorong oleh adanya ketakutan sangsi sosial atau masyarakat dan budaya yang berlaku, khususnya berbelanja pakaian. Banyaknya iklan dan mudahnya mengakses produk fashion di media sosial ini semakin menguatkan kecenderungan mahasiswi untuk melakukan pembelanjaan secara kompulsif (Dittmar, Long, \& Bond, 2007). Mahasiswi yang 
memiliki contingent self-esteem tinggi cenderung memonitor dan membandingkan dirinya khususnya penampilannya, karena pakaian dapat menyimbolkan citra diri atau merupakan presentasi dirinya. Mereka cenderung memantau produk fashion yang sedang trend, agar mereka mampu menjadi pemakai pakaian fashion pemula. Reaksi positif atau reinforcement positif dari orang di sekitarnya ini merupakan sebuah prestasi yang membanggakan.

Hasil penelitian juga menemukan bahwa mahasiswi dengan contingent self-esteem tinggi cenderung menggunakan strategi coping menghindar (avoidance coping) ketika dihadapkan pada persoalan kehidupan. Riset yang dilakukan Otero-Lopes \& Villardefracos (2014) menemukan bahwa strategi coping yang mereka gunakan adalah passive-avoidance dengan tujuan untuk menghindari problerm, impian khayal, mengkritik diri sendiri, menarik diri dari orang lain, dan memiliki skor rendah pada strategi active-focus dalam pemecahan masalah dan menyusun kembali pikirannya (cognitive restructuring). Hal ini mengindikasikan bahwa rasa khawatir terhadap reaksi negatif orang lain terhadap dirinya ini mendorong mereka untuk memenuhi harapan orang sekitarnya.

Penelitian ini juga menemukan bahwa avoidance coping mampu memperkuat hubungan antara contingent self-esteem dengan kecenderungan melakukan belanja kompulsif pakaian. Hal ini menunjukkan bahwa mahasiswi dengan contingent self-esteem tinggi memiliki kecenderungan melakukan belanja kompulsif. Apalagi ketika mereka juga cenderung menggunakan strategi avoidance coping dalam mengatasi permasalahan, maka mereka cenderung memiliki dorongan yang sangat kuat untuk melakukan pembelanjaan secara kompulsif. Hasil penelitian juga menemukan bahwa avoidance coping mampu memediasi hubungan contingent self-esteem dengan belanja kompulsif pakaian secara parsial. Belanja kompulsif pakaian merupakan cara anak-anak muda untuk mengatasi persoalan atau distress yang dialami. Ketika mereka sedang jenuh dengan aktivitas kampus atau sedang mengalami distress psikologis, mereka cenderung melakukan pembelanjaan kompulsif pakaian. Hasil penelitian ini juga mendukung temuan Otero-Lopes \& Villardefracos (2014) bahwa belanja kompulsif ini merupakan cara untuk mengatasi distress psikologis yang dialami.

\section{SIMPULAN DAN IMPLIKASI}

Hasil penelitian menunjukkan bahwa mahasiswi dengan contingent self-esteem tinggi atau memiliki harga diri (self-esteem) rendah cenderung melakukan pembelanjaan kompulsif pakain. Belanja kompulsif pakain yang dilakukan bertujuan untuk mendapatkan perasaan berharga dari reaksi positif orang lain. Kecenderungan belanja kompulsif ini juga akan semakin tinggi ketika cara mendekati permasalahan yang dimiliki avoidance coping. Ketika mereka dihadapkan problem kehidupan mereka cenderung melarikan diri dari permasalahan dengan melakukan pembelanjaan.

Berdasarkan temuan di atas, maka Pengelola Universitas Muhammadiyah Malang yang berperan mengembangkan aktivitas ekstra kurikuler mahasiswa dapat menyusun program 
ekstrakurikuler, pelatihan problem solving atau sejenisnya yang menarik. Mahasiswi dapat belajar mengelola keuangan dan banyak melibatkan diri dalam aktivitas positif yang dapat mengembangkan potensinya.

\section{REFERENSI}

Azwar, S. (2012). Penyusunan Skala Psikologi. Yogyakarta: Pustaka Pelajar.

Benson, A.L., Dittmar, H.E.\& Wolfsohn, R. (2010). Compulsive buying: cultural contributors and consequences in impulse control disorders: a clinical guide. London: Cambridge University Press.

Biolceti, R. (2017). The role of self-esteem and fear of negative evaluation in compulsive buying. Frontiers in Psychiatry, 8 (74), 1-8. Doi: 10.3389/fpsyt.2017.00074

Billieux, J., Rochat, L., Rebetez, M.M.L. dan Linden, M.V.D. (2008). Are all facets of impulsivity releted to self-reported compulsive buying behavior?.Personality and Individual Differences, 44, 1432-1442. Doi:10.1016/j.paid.2007.12.011

Chan, K. \& Zhang, C. (2007). Living in a celebrity-mediated social world: The Chinese experience. Young Consumers, 8 (2), 139-152

Childers, T.L. \& Rao, A.R. (1992). The influence familial and peer-based refference groups on consumer decision. Journal of Consumer Research, 19, 198-211.

Chivaneh, M. (2013). The examination of reliability and validity of coping responses inventory among Iranian students. 3rd World Conference on Psychology, Counselling and Guidance (WCPCG-2012). Procedia - Social and Behavioral Sciences 84, $607-614$

Dittmar, H. dan Drury, J. (2000). Self-image - is it in the bag? a qualitative comparison between "ordinary" and "excessive consumers". Journal of Economic Psychology, $21,109-142$

Dittmar, H. (2004). Are you what you have?consumer society . The Psychologist, 17 (4), 206-211.

Dittmar, H. (2005). Compulsive buying - a growing concern? An examination of gender, age, and endorsement of materialistic values as predictors. British Journal of Psychology, 96, 467-491. Doi: 10.1348/000712605x535333

Dittmar, H., Long, K. \& Bond, R. (2007). When a better self is only a button click away: associations between materialistic values, emotional and identity-related buying motives, and compulsive buying tendency online. Journal of Social and Clinical Psychology, 26 (3), 334-361. Doi: 10.1521/jscp.2007.26.3.334 
Djudiyah. (2017). Pengaruh nilai materialistik dan kepribadian neurotik terhadap belanja kompulsif dengan faktor moderasi kebersyukuran kepada Tuhan. Disertasi. Bandung: Fakultas Psikologi Universitas Padjadjaran.

Dziurzyńska, E., Pawłowska, B. \& Potembska, E. (2016). Coping strategies in individuals at risk and not at risk of mobile phone addiction. Curr Probl Psychiatry, 17 (4), 250-260. Doi: 10.1515/cpp-2016-0024

Ergin, E.A. (2010). Compulsive buying behavior tendencies: the case of Turkish consumer. African Journal of Bussiness Management, 4 (3), 333-338.

Farida, I. (2011). Perilaku konsumtif mahasiswa yang tinggal indekost. Skripsi. Jakarta: Fakultas Psikologi Universitas Gunadarma. http://library.gunadarma.ac.id/repository/view/319549/perilaku-konsumtifmahasiswa-yang-tinggal-indekost.html/

Horvath, C., Adiguzel, F. \& Herk, H.V. (2013). Cultural aspects of compulsive buying in emerging and developed economies: a cross cultural study in compulsive buying. Organization and Market in Emerging Economies, 4 (2), 8-24.

Hurlock, E.B. (2004). Developmental psychology. A life-span approach (Terjemahan). Fifth Edition. New York: McGraw-Hill, Inc.

Johnson, T. \& Attmann, J. (2009). Compulsive buying in a product specific contect: clothing. Journal of Fashion Marketing and Management, 13 (3), 394-405. Doi:10.1108/13612020910974519

Johnson, M. \& Blom, V. (2007). Development and validation of two measures of contingent self-esteem. Individual Differences Research, 5 (4), 300-328.

Lazarus, R. S. (1993). Coping theory and research: past, present and future. Psychosomatic Medicine, 55, 234-247.

Lejoyeox, M., Benhaim, C.R., Betizeau, A., Lequen, V. \& Lohernhardt, H. (2011). Money attitude, self-esteem, and compulsive buying in a population of medical students. Frontiers in Psychiatry, 2 (13), 1-5. Doi:10.3389/fpsyt.2011.00013

Lee, Y. J., \& Park, J. K. (2008). The mediating role of consumer conformity in ecompulsive buying. Advances in Consumer Research, 35, 387-392.

Liu, C. \& Laird, R. (2008). Parenting, peer influence, and role model on compulsive buying tendencies of early adolescent consumers. Advances in Consumer Research, 35 , 1037-1038. http://www.acrwebsite.org/volumes/v35/naacr_vol35_465.pdf

Lo, H. \& Harvey, N. (2012). Effects of shopping addiction on consumer decision making: web-based studies in real time. Journal of Behavioral Addiction (In Press), $1-28$. 
Mangestuti, R. (2014). Model pembelian kompulsif pada remaja. Disertasi. Yogyakarta: Program Doktor Psikologi Fakultas Psikologi Universitas Gadjah Mada.

McNicol, M. L. \& Thorsteinsson, E. B. (2017). Internet addiction, psychological distress, and coping responses among adolescents and adults. Cyberpsychology Behavior and Social Networking. 20 (5), 296-303. Doi: 10.1089/cyber.201

Moos, R. H. (2004). Coping responses inventory: an update on research applications and validity. Odessa. FL: Psychological Assessment Resources.

Neuman, W.L. (2000). Social research methods. Qualitative and Quantitative Approaches. Fourth Edition. Boston: Allyn and Bacon.

Otero-Lopes, J.M. \& Villardefracos, C. (2014). Prevalence, sociodemographic factors, psychological distress, and coping strategies related to compulsive buying: a cross sectional study in Galicia, Spain. BMC Psychiatry, 14, 1-12. Doi:101186/1471-244x-14-101

Patrick, H., Neighbors, C., \& Knee, C. R. (2004). Appearance-related social comparisons: the role of contingent self-esteem and self-perceptions of attractiveness. Personality and Social Psychology Bulletin, 30 (4), p. 501-514. Doi: $10.1177 / 0146167203261891$

Priyadana, A. (2018). Perilaku konsumen digital Indonesia. https://marketing.co.id/perilaku-konsumen-digital-indonesia/

Rath, P. M, Bay, S. Petrizzi, R., \& Gill, P. (2015). The why of the buy. Consumer behavior and fashion Marketing. New York: Fairchild Books, Inc.

Ridgway, N.M., Kukar-Kennay, M. \& Monroe, K.B. (2006). New perspective on compulsive buying: its roots, measurement and Physiology. Advances in Consumer Research, 33, p. 131-133.

Ryan, A. M. (2001). The peer group as a context for the development of young adolescence motivation and achievement. Child Development, 72 (4), p.11351150

Setiana, R. 2013. Waspadai gaya hidup konsumtif dan shopaholic!. 20 April 2013. http://mjeducation.co/waspadai-gaya-hidup-konsumtif-dan-shopaholic/

Servidioa, R., Ambra Gentileb, A., \& Bocab, S. (2018). The mediational role of coping strategies in the relationship between self-esteem and risk of internet addiction. Europe's Journal of Psychology, 14(1), 176-187. Doi:10.5964/ejop.v14i1.1449

Sharma, B., Raciti, M., O’Hara, R. \& Reinhard, K. (2013). A tri-country social marketing study of young university women's alcohol consumption and the perceived influence of their peers' attitudes. e-Journal of Social and Behavioral Research in Bussiness, 4 (1), p. 1-11. http://www.esjbrb.org 
Shareef, M.A., Dwivedi, Y.K., \& Kumar, V. (2016). Mobile marketing channel online consumer behavior. Switzerland: Springer International Publishing. Doi:10.1007/978-3-319-31287-3

Shrestha, T. (2013). Self-esteem and stress coping among proficiency certificate level nursing students in nursing campus Maharajgunjand LalitpurNursing Campus. $J$ Nepal Health Res Counc, 11(25), 283-288

Suryabrata, S. (2012). Metodologi penelitian. Jakarta: PT. RajaGrafindo Persada.

Undheim, A. M. \& Sund, A. M. (2017). Associations of stressful life events with coping strategies of 12-15-year-old Norwegian adolescents. Eur Child Adolesc Psychiatry, Doi: 10.1007/s00787-017-0979-x

Ureta, I.G. (2007). Addictive buying: causes, processes, and symbolic meanings, thematic analysis of a buying addict's diary. The Spanish Journal of Psychology, 10 (2), 408-422. ISSN 1138-7416 


\title{
PELATIHAN KONTROL DIRI UNTUK MENGURANGI KECENDERUNGAN INTERNET GAMING DISORDER PADA ANAK USIA SEKOLAH
}

\author{
Ria Fatma Ramadhani ${ }^{1}$, Iswinarti ${ }^{2}$, Uun Zulfiana ${ }^{3}$ \\ ${ }^{1,2,3}$ Fakultas Psikologi, Universitas Muhammadiyah Malang \\ ${ }^{1}$ rfatmar19@gmail.com, ${ }^{2}$ iswinarti.psi@gmail.com, ${ }^{3}$ uun@umm.ac.id
}

\begin{abstract}
Abstrak. Pada zaman yang semakin canggih ini penggunaan gadget tidak terbatas pada kalangan orang dewasa saja melainkan anak-anak juga telah menggunakan gadget. Gadget digunakan untuk membantu memenuhi segala kebutuhan salah satunya adalah kebutuhan mencari hiburan dengan bermain game, yang dengan mudah bisa dimainkan dengan menggunakan internet. Penggunaan internet untuk bermain game secara terus menerus dan mengakibatkan dampak negatif bagi dirinya akan menyebabkan internet gaming disorder. Tingginya tingkat internet gaming disorder pada anak dapat diatasi, salah satunya dengan memberikan pelatihan kontrol diri. Penelitian ini bertujuan untuk memberikan pelatihan konrol diri sebagai metode eksperimen dalam mengurangi tingkat internet gaming disorder pada anak usia sekolah serta melihat seberapa besar pengaruh perlakuan pada tingkat internet gaming disorder. Penelitian ini merupakan penelitian eksperimen dengan desain control group pre-test post-test. Penelitian ini dilakukan pada 12 orang anak usia sekolah 9-11 tahun dengan menggunakan teknik purposive sampling yang terbagi menjadi 2 grup. Hasil penelitian menunjukkan adanya pengaruh signifikan pelatihan kontrol diri terhadap tingkat internet gaming disorder $(\mathrm{p}=0,04$ dimana nilai $\mathrm{p}$ $<$ 0,05). Dengan begitu, pelatihan kontrol diri dapat menurunkan internet gaming disorder pada anak usia sekolah.
\end{abstract}

Kata kunci: Internet Gaming Disorder, Pelatihan Kontrol Diri, Anak Usia Sekolah

Abstract. In this particular sophisticated era, the use of gadget is not limited only within the reach of the adults but also children for the sake of fulfilling many of the needs which one of it happened to be the need of entertainment through internet gaming. The use of internet for playing games continuously with its negative effect will lead to an Internet Gaming Disorder. High level of Internet Gaming Disorder can be overcome, one of it would be by giving a self-control training. This research aims to apply a self-control training as an experimental method to reduce the level of Internet Gaming Disorder in children as well as sighting at how much of an impact the intervention will be on the level of IGD. This research is experimental with control group pre-test post-test design. 12 children with the age of 9-11 will be chosen as participants through purposive sampling technique. The result of this research showed that there is a significant impact of a self-control training towards the level of igd $(p=0.04)$. With that being said, selfcontrol training is capable of reducing the level of igd in children.

Keyword: Internet Gaming Disorder, Self-control training, Schooler 
Perkembangan teknologi komunikasi dari tahun ke tahun sangatlah cepat, banyak gadget keluaran terbaru dengan piranti-piranti pendukungnya yang begitu canggih dan berbagai macam kelebihan yang ditawarkan tidak bisa dihindarkan oleh banyak kalangan masyarakat. Sudah menjadi hal yang umum bila masyarakat dihadapkan pada berbagai situasi yang membuat mereka untuk melek terhadap teknologi yang berkembang saat ini. Berawal dari kebutuhan untuk memenuhi kebutuhan komunikasi yang sederhana seperti pesan singkat serta pesan suara, namun saat ini alat-alat teknologi komunikasi menjadi multifungsi sebagai sarana atau media untuk memfasilitasi pembelajaran diluar kelas, hiburan portable, kegiatan jual-beli, atau hanya sekedar mencari informasi dengan menggunakan jaringan internet. Secara umum, anak-anak usia muda dari setiap kalangan memiliki peralatan berteknologi (gadget) dengan rentang jenis dan level yang berbeda. Terlebih untuk anak-anak usia sekolah yang menempatkan penggunaan teknologi sebagai salah satu prioritas utama dalam pemenuhan kebutuhan seperti proses pembelajaran dan pengerjaan tugas.

Anak usia sekolah bisa dikatakan masa kanak-kanak akhir yakni usia 6-12 tahun Pada masa ini anak mulai untuk meningkatkan kemampuan yang ada, mulai menguasi tanggung jawab dan proses berfikir yang lebih logis dan kritis (Santrock, 2011). Daya ingat anak bekembang semakin kuat, serta anak dapat membedakan mana yang terlihat oleh indra dan kenyataan sesungghunya serta mana yang bersifat sementara dan mana yang menetap anak tidak lagi berfikir dengan egosentris dan sudah mulai mampu menilai dari sudut orang lain.Anak juga akan mengembangkan ide kreatifnya dan keterampilannya, serta belajar mengenal tentang lingkungan yang lebih luas bukan hanya lingkungan keluarganya saja tetapi juga dari sekitarnya, seperti mulai mengenal media.

Kecenderungan untuk selalu mengggunakan media teknologi atau gadget adalah salah satu fenomena yang sangat pesat berkembang. Gadget memiliki banyak fungsi bagi penggunanya sehingga dinilai lebih memudahkan. Kemudahan itu juga yang membuat seluruh individu dari seluruh kategori usia sangat bergantung terhadap gadget terutama anak-anak dan remaja (Rohmah, 2017). Berbagai macam dampak bisa terjadi dari bergantungnya terhadap kemudahan yang ditawarkan bagi pengguna gadget, terutama dikalangan masyarakat pada usia anak-anak dan remaja. Banyak anak-anak yang diperbudak dengan yang namanya gadget. Anak-anak usia 9-12 tahun yang telah menggunakan gadget di kehidupan sehari-hari, baik untuk hiburan maupun berkomunikasi dengan orang lain. Penggunaan gadget ini pun banyak didukung oleh orang tua dilihat dari banyaknya jumlah anak yang memiliki gadgetnya sendiri. Akibatnya mayoritas anak banyak yang menghabiskan waktu luang untuk bermain dengan menggunakan gadget.

Pengenalan gadget terlalu dini pada anak dapat memberikan dampak positif maupun negatif. Hal ini dipengaruhi oleh beberapa faktor seperti frekuensi dan durasi pemakaian, serta pengawasan orang tua. Penggunaan gadget sebagai bahan dasar pembelajaran pada anak akan berdampak positif seperti meningkatkan kreativitas dan daya pikir anak. Begitupula sebaliknya, bila pengawasan dari orang tua kurang dan tidak ada upaya yang tegas dalam pembagian waktu pemakaian gadget pada anak akan dapat menimbulkan sisi negatif. Dampak negatif tersebut mampu menyebabkan seseorang menjadi pemalu, 
kurang percaya diri, menyendiri dan keras kepala. Seperti yang dipaparkan oleh Iswidharmanjaya (2011), salah satu dampak dari penggunaan gadget adalah anak menjadi pribadi yang cenderung menyendiri. Dengan begitu anak akan merasa asing dan kurang peka terhadap lingkungan disekitarnya. Intensitas bermain dengan teman sebayanya secara perlahan akan semakin berkurang, sehingga sosialisasi dengan lingkungan sekitar pun semakin berkurang. Pebriana (2017) menunjukkan bahwa salah satu dampak negatif penggunaan gadget adalah keluhan orang tua terhadap ketidakpatuhan anak saat disuruh untuk membantu mengerjakan pekerjaan rumah atau bahkan belajar.berbicara tentang dampak gadget tentu juga akn berbicara efeknya terhadap kesehatan. Menurut Navarona (2016) pada penelitian yang dilakukannya, lama waktu saat menggunakan gadget yang lebih dari dua jam dan pencahayaan yang digunakan saat menggunakan gadget adalah pencahayaan yang terang maka akan berdampak pada gangguan kesehatan mata penggunanya.

Data-data di atas dijadikan awal untuk dilakukannya penelitian pada salah satu kelurahan yang ada di kota Malang, kelurahan Blimbing. Data hasil penelitian yang dilakukan pada tahun 2017 tersebut menunjukkan bahwa mulai terjadi permasalahan terkait interaksi sosial anak terhadap teman sebayanya, kesehatan mata, kepatuhan terhadap perintah orangtua, dan permasalahan yang paling utama adalah kecenderungan adiksi terhadap gadget. Hal ini terlihat dari 18 dari 20 anak sekolah kelas 3 sampai 6 berada dalam kategori tinggi untuk hasil skor kecenderungan adiksi dan 2 lainnya berada dalam kategori rendah. Juga terdapat 19 anak yang menggunakan gadgetnya lebih dari 3 jam dalam sehari menurut Judhita (2011) anak usia sekolah di kelurahan Blimbing masuk dalam kategori pengguna gadget dengan intensitas tinggi. Penggunaan gadget yang dilakukan anak-anak kelurahan Blimbing sebagian besar adalah untuk mengakses sosial media dan juga bermain game yang terhubung dengan jaringan internet seperti mobile legend.

Banyaknya perangkat teknologi dengan mudah diakses dan gadget-gadget yang menggunakan jaringan internet membantu anak usia sekolah untuk memenuhi kebutuhannya dalam mencari hiburan. Banyak permainan-permainan yang terhubung oleh internet (internet gaming) yang menawarkan kelebihan-kelebihan yang bisa membuat anak-anak semakin betah untuk menggunakannya. Sejak tahun 2012 internet gaming merupakan permainan populer yang dimainkan lebih dari satu miliyar orang (Kuss, 2013). Internet gaming yang membebaskan para pemain untuk menciptakan dunia mereka sendiri, seperti menciptakan karakter yang sesuai dengan keinginan mereka, dan juga bebas bermain dengan pemain yang berada di lokasi lain. Hal ini membuat para pemain menjadi lebih sibuk dalam kehidupannya di dalam permainan sehingga membuat kabur antara yang nyata dan yang tidak. Menurut Griffiths dan Pones (2015), para gamer akan mengorbankan waktu dan aktivitas lain untuk bermain game, seperti untuk melakukan hobi-hobi lain, waktu tidur, bekerja ataupun belajar, bersosialisasi dengan teman dan keluarga. Anak-anak dan remaja dianggap lebih rentan terhadap memainkan game online dibandingkan orang dewasa (Griffiths \& Wood, 2000).

Berbagai penelitian terkait internet gaming disorder (IGD) telah dilakukan di berbagai negara dan pada umumnya dilakukan di kalangan remaja. Salah satunya yang dilakukan 
pada anak muda di Amerika yang berusia 8-18 tahun, 8,5\% dari mereka teridentifikasi berada dalam internet gaming disorder rate (Gentile, 2009). Dalam artikel yang ditulis oleh Markey \& Furguson (2017) hampir 19000 partisipan dari Amerika, Inggris, Kanada, dan Jerman yang sudah mengisi cheklis memiliki simptom-simptom yang bisa didiagnosis sebagai simptom internet gaming disorder. Selain itu, penelitian tentang prediksi simptom internet gaming disorder di remaja awal oleh Peeters, Koring, dan Eijnden (2017) yang mengungkapkan adanya efek kerentanan sosial dan kepuasan hidup dalam peningkatan gejala IGD dikalangan usia muda.

Penelitian lain yang dilakukan oleh Wartberg, Kriston, Kramer, Schwedler, Lincoln, \& Kammerl (2016) menjelaskan bahwa terdapat hubungan yang signifikan antara internet gaming disorder dan remaja laki-laki, permasalah kontrol emosi, harga diri, kurangnya perhatian serta kecemasan orangtua. Menurut Sioni, Bulerson, dan Bekerian (2017) dalam penelitiannya mengeksplorasi adanya hubungan yang signifikan antara gejala IGD dengan dua faktor potensi lain yang beresiko yakni fobia sosial dan juga intentifikasi avatar (karakter) yang dikuakan gamer dalam jam mingguan mereka memainkan game internet. Penelitian lain juga dilakukan oleh Bargeron \& Hormes (2016) tentang korelasi psikososial dari internet gaming disorder yang menjelaskan tentang gejala-gejala pada orang-orang dengan IGD termasuk melakukan kebiasaan buruk di sekolah karena waktu bermain mereka yang berlebihan, melewatkan tugas lain, menghabiskan banyak waktu untuk berfikir tentang game mereka, dan penggunaan video game untuk menghindari masalah atau perasaan negatif tertentu.

Beberapa bukti yang dipaparkan di atas kemudian didukung oleh masuknya internet gaming disorder dalam gangguan di DSM-V terbaru karena dampak negatifnya yang dilaporkan sangat luas baikdalam kesehatan mental maupun fisik individu. Dalam DSMV yang terbaru ini, American Psychiatric Association (APA) menerapkan beberapa perubahan pada deskripsi dan kriteria perilaku-perilaku patologis dan didalamnya termasuk internet gaming disorder sebagai gangguan didalam appendix manual ini (APA, 2013). Pengenalan tentang dampak internet gaming disorder sejak dini Pengenalan tentang identifikasi internet gamig disorder sejak dini pada anak usia sekolah sangat berguna agar bisa dengan cepat megetahui cara penanganan, dan pencegahan yang pas agar tidak bisa mengurangi dampak yang ditimbulkan, serta bisa menjadi referensi dalam penelitian-penelitian lain kedepannya. Hal tersebut meningkatkan urgensi dalam penanganan permasalahan ini terutama jika telah dilakukan semenjak usia anak sekolah. Untuk itu, peneliti mencoba menarik permasalahan internet gaming disorder (IGD) pada anak usia sekolah sebagai sebuah isu yang akan dicegah menggunakan intervensi yang sesuai. Peneliti tertarik untuk mengambil sampel anak usia sekolah karena pada masa ini anak lebih sering rentan terhadap jenis-jenis permainan internet.

Pengangan untuk permasalahan internet gaming disorder telah dilalukan di berbagai penelitian. Seperti penelitian Rodriguez \& Griffith (2017) yang membahas penaganan IGD pada remaja berusia 12-18 tahun. Rodriguez \& Griffith (2017) menggunakan metode PIPATIC yang memakai konsep pelatihan sebagai salah satu item program. Oleh karena itu dalam penelitian ini peneliti akan mengacu pada konsep pelatihan. Peneliti akan menggunakan pelatihan kontrol diri dapat digunakan untuk menangani 
permasalahan perilaku dan kognisi agar sesuai dengan apa yang diinginkan. Menurut Janah (2014) pelatihan kontrol diri berpengaruh signifikan dalam mengurangi perilaku merokok pada siswa. Rokok termasuk dalam substance dependence begitu pula dengan internet gaming dalam penelitian yang dilakukan oleh Kuss (2013) yang ditemukan memiliki banyak kesamaan dengan adiksi lainnya pada temasuk substance dependence pada level molekular, dan perilakunya. Young (2009) juga menganggap ada kesaam dari kriteria substance dependance dalam DSM-IV dengan yang ia temukan pada subjek adiksi internet.

Metode pelatihan dapat dilakukan pada anak usia sekolah mengacu pada penjelasan Santrock (2011) bahwa anak usia sekolah sudah mulai bisa berpikir kritis dan logis, serta mulai mengembangkan strategi pemecahan masalah. Pelatihan yang akan dilakukan berisi identifikasi, edukasi, mini game dan Informational Video akan membatu anak membentuk perspektif dan perilaku anak serta menangani terjadinya IGD sejak dini pada anak usia sekolah. Upaya penanganan tersebut merupakan tujuan sekaligus manfaat dari penelitian ini, yaitu mengidentifikasi apakah pilihan intervensi yang digunakan dapat mengurangi tingkat internet gaming disorder pada anak usia sekolah.

\section{Pelatihan Kontrol Diri dan Internet Gaming Disorer}

Penelitian tentang treatment pada IGD dengan menggunakan metode PIPATIC, yang terdiri dari motivational interviewing, edukasi, person-centered therapy, self regulation training strategies untuk remaja. Dari beberapa alternatif yang telah diberikan, peneliti muncul dengan ide yaitu pelatihan kontrol diri berisi edukasi, identifikasi, games yang akan menyasar pada kognitif dan perilaku anak.

Pelatihan merupakan kegiatan yang dirancang untuk memodifikasi pengetahuan, keterampilan dan sikap melalui proses pengalaman belajar. Edralin (2004) menyebutkan bahwa pelatihan merupakan proses intervensi yang sistematik untuk meningkatkan pengetahuan, kemampuan, dan keterampilan. Sedangkan kontrol diri itu sendiri menurut Chaplin (2006) merupakan suatu upaya yang dilakukan oleh individu untuk membimbing tingkahlakunya agar dapat menekan impuls-impuls dari perilaku impulsif. Kontrol diri lebih pada menekan pada pilihan tindakan dengan cara menunda kepuasaan sesaat (delay gratification). Ghufron dan Risnawita (2010) menyebutkan bahwa kontrol diri merujuk pada kemampuan untuk mengelola faktor dari perilaku yang sesuai dengan kondiri tertentu untuk menampilkan kemampuan mengendalikan perilakunya agar sesuai dan dapat menyenangkan orang lain

Pelatihan kontrol diri yang dilakukan bisa memberikan manfaat dan dampak pada pengaruh yang diinginkan ketika individu tersebut ingin mengontrol dirinya. Pelatihan kontrol diri dapat membantu individu untuk menghadapi suatu kondisi yang terjadi di lingkungan sekitarnya. Para ahli juga berpendapat kontrol diri bisa digunakan sebagai metode intervensi dan juga preventif yang dapat mereduksi efek negatifnya stresor di sekitar. Menurut Averill (Ghufron dan Risnawita, 2010) ada beberapa aspek dalam konrol diri:

1. Behavioral control, yakni kontrol dalam mengambil tindakan

2. Cognitif control, yakni bagaimana memodifikasi proses berfikir seseorang 
3. Decission control, yakni kesempatan untuk memilih dan mengambil keputusan atau tujuan alternatif dari tindakan yang akan dilakukan

Kemampuan seseorang dalam mengontrol dirinya menurut Tangney, Baumeister dan Boone (2004) dipengaruhi oleh 3 aspek: a.) melanggar kebiasaan, berkaitan dengan perilaku diluar kebiasaan dan kurang mampu mematuhi norma sekitarnya; b.) menahan godaan, berkaitan tentang bagai mana sikap dalam melakukan tugasnya; c.) disiplin diri, berkaitan dengan bagaimana kemampuan untuk mengontrol dirinya.

Averill (dalam Nurhayati, 2013) menyebutkan bahwa ada beberapa aspek-aspek kontrol diri pada individu, diantaranya mengontrol perilaku terdiri dari kemampuan mengatur pelaksanaan dan kemampuan mengontrol stimulus, mengontrol kognitif terdiri dari kemampuan mengolah informasi, kemampuan melakukan penilaian positif serta mengontrol keputusan atau kemampuan mengambil keputusan agar apa yang dilakukan individu mengarah kepada perilaku yang positif. Berdasarkan aspek yang termuat dalam self control dapat diketahui bahwa self control tidak hanya menekankan pada stimulus datangnya perilaku, tetapi juga rasionalis mengenai penilaian perilaku yang akan dimunculkan baik apa tidak. Besarnya efek yang ditimbulkan kontrol diri, beberapa peneliti menyebutkan jika kontrol diri dapat digunakan sebagai metode intervensi (Ghufron dan Rini, 2010).

Kontrol diri tidak dapat berkembang begitu saja, namun kontrol diri dapat dikembangkan melalui latihan yang dilakukan secara terus menerus. Pelatihan kontrol diri sangat bermanfaat untuk dapat mengembangkan kontrol diri itu sendiri dan memberikan dampak positif dalam pengelolaan emosi dan mengurangi perilaku yang buruk bagi individu (Muraven, 2010). Pelatihan sendiri merupakan salah satu cara pengembangan sumber daya manusia. Pengembangan dilakukan meliputi pemberian kesempatan belajar yang bertujuan untuk mengembangkan individu pada saat ini dan masa yang akan mendatang. Pelatihan dilakukan untuk memberikan kegiatan yang berfungsi meningkatkan kinerja seseorang dalam pekerjaan atau tugasnya sekarang. Pelatihan dilakukan untuk membantu individu agar menjadi lebih efektif (Afiatin, 2013).

Seperti yang sudah dijelaskan, subjek dengan IGD sering menunjukkan gangguan pada kognitif yang berkaitan dengan perilaku impulsif yang meningkat, serta gangguan kontrol kognitif dan juga waktu. Subjek IGD juga menunjukkan beberapa perasaan negatif seperti rasa cemas dan tidak bisa lepas dari bermain game. Dengan melatih kontrol diri yang bisa membantu menekan perasaan negatif dan stimulus yang mendorong munculnya perilaku negatif. Seperti metode PIPATIC yang mana salah satu metode yang digunakan adalah metode strategi pelatihan, peneliti juga akan menggunakan metode pelatihan yakni pelatihan kontrol diri yang akan diberikan pada anak usia sekolah. Menurut Piaget (Santrock, 2011) pada usia sekitar 6 hingga 12 tahun anak berada pada tahap operational konkret, pada tahap ini anak-anak dapat melakukan operasi konkret, mereka juga dapat bernalar secara logis sejauh penalaran itu dapat diaplikasikan pada contoh-contoh yang spesifik atau konkret. Dari penjelasan tersebut metode pelatihan kontrol diri dapat diaplikasikan dengan baik. Dengan memberikan bukan hanya edukasi tetapi juga identifikasi, video informatif serta mini game yang akan sedikit banyak 
memobilisasi efek perubahan kognitif dan perilaku anak, juga akan berpengaruh besar dalam pembentukan perpektif pada anak.

\section{Hipotesis}

Pelatihan kontrol diri dapat mengurangi internet gaming disorder anak usia 9-11 tahun di SD.

\section{METODE}

Pada penelitian ini, pendekatan yang digunakan adalah kuantitatif dan berjenis eksperimen penelitian eksperimen dilakukan untuk mengetahui akibat yang ditimbulakn dari suatu perlakuan yang diberikan. Latipun (2002) menjelaskan bahwa eksperimen dilakukan dengan mengadakan manipulasi perlakuan yang bertujuan untuk mengetahui akibat manipulasi terhadap perilaku individu yang diamati. Desain eksperimen yang digunakan dalam penelitian ini adalah desain between subject dan model pretest-posttest kontrol group design. Dalam desain ini terdapat dua kelompok (eksperimen dan kontrol) yang dipilih kemudian menilai perbedaan diantara dua kelompok.

Tabel 1 skema desain eksperimen

\begin{tabular}{cccc}
\hline Kelompok & Tahap I & Tahap II & Tahap III \\
\hline Eksperimen & Pretest & Perlakuan & Post-test \\
\hline Kontrol & Pretest & - & Post-test \\
\hline
\end{tabular}

Subjek penelitian ini adalah siswa sekolah dasar. Pengambilan subjek menggunakan teknik purposive sampling yaitu teknik pengambilan sampel berdasarkan pertimbangan tertentu (Sugiyono, 2014). Subjek yang digunakan berjumlah 12 orang dimana 6 subjek masuk pada kelompok eksperimen dan 6 orang subjek pada kelompok kontrol. Kriteria dalam penentuan subjek adalah anak usia 9-111 tahun, bersekolah di SDN Mojolangu 5, orangtua bersedia menjadi subjek penelitian dan anak memiliki skor tinggi skor skala IGD20-test yang tinggi. Pembagian subjek kedalam kelompok kontrol dan kelompok eksperimen dilakukan dengan melihat urutan skor pretest subjek. Bagi subjek yang memiliki skor pretest tinggi 6 pertama akan dimasukkan kedalam kelompok eksperimen dan 6 subjek lainnya ditempatkan pada kelompok kontrol.

Peneliatian eksperimen meneliti hubungan sebab akibat dan bukan hanya meneliti hubungan antar variabel. Dalam penelitina ini akan meneliti 2 variabel, variabel bebas bebas atau $\mathrm{X}$ adalah Pelatihan kontrol diri dan untuk variabel terikat atau $\mathrm{Y}$ adalah Internet Gaming Disorder

Pelatihan kontrol diri adalah suatu metode intervensi yang dilakukan untuk memberikan keterampilan pada indivisu agar bisa mengendalikan dorongan-dorongan yang ada dalam dirinya serta sekitarnya. Pelatihan yang akan dilakukan dengan pemberian edukasi dan video-video informatif terkait internet gaming, faktor-faktor penghambat dan pendorong, dampak negatif bila berlebihan games, tips bagaimana megurangi, mini game, serta pemberian remind card sebagai tugas untuk mengurangi penggunaan internet gaming. Setiap kegiatan pada pelatihan ini memiliki makna yang tersembunyi, dan manfaat dari 
kegiatan-kegiatan tersebut adalah memberikan pengetahuan, keterampilan, dan sikap mengontrol diri sendiri.

Tabel 2 Kegiatan Pelatihan dan Aspek Kontrol Diri

\begin{tabular}{|c|c|c|}
\hline Kegiatan & Bentuk Kegiatan & Aspek Kontrol Diri \\
\hline $\begin{array}{l}\text { Butter cake } \\
\text { jelly }\end{array}$ & $\begin{array}{l}\text { Anak akan diberi berbagai } \\
\text { macam warna bola dimana tiap } \\
\text { warna bola memiliki instruksi } \\
\text { yang berbeda-beda }\end{array}$ & $\begin{array}{l}\text { Kegiatan ini mencerminkan } \\
\text { bagaimana anak akan } \\
\text { mengolah stimulus yang } \\
\text { diterima dengan peraturan } \\
\text { yang ada, serta keputusan } \\
\text { apa yang akan dilakukan } \\
\text { saat menerima stimulus } \\
\text { tersebut. }\end{array}$ \\
\hline $\begin{array}{l}\text { Pemberian } \\
\text { materi dna } \\
\text { juga } \\
\text { pemberian } \\
\text { video } \\
\text { informatif }\end{array}$ & $\begin{array}{l}\text { Kegiatan ini akan memberikan } \\
\text { gambaran kepada anak tentang } \\
\text { permasalahan dalam bermain } \\
\text { game yang sedang dihadapnya, } \\
\text { apa saja faktor penyebab dan } \\
\text { pendorong, Kegiatan ini juga } \\
\text { akan disuguhkan dengan video } \\
\text { informatif }\end{array}$ & $\begin{array}{l}\text { Aspek kontrol perilaku, } \\
\text { kontrol kognisi, dan kontrol } \\
\text { keputusan. }\end{array}$ \\
\hline $\begin{array}{l}\text { Lembar } \\
\text { evaluasi }\end{array}$ & $\begin{array}{l}\text { Anak diminta untuk menjawab } \\
\text { pertaanyaan yang ada serta } \\
\text { membeyankan konsekuensi yang } \\
\text { kan didapat jika melakukan apa } \\
\text { yang tertulus pada kertas } \\
\text { tersebut. }\end{array}$ & $\begin{array}{l}\text { Kegiatan ini mencerminkan } \\
\text { bagaimana anak akan } \\
\text { mengambil keputusan } \\
\text { terkait menahan dorongan } \\
\text { negative } \\
\text { membiarkannyar } \\
\text { tersebut termasuk kedalam } \\
\text { aspek kontrol keputusan } \\
\text { dalam kontrol diri. }\end{array}$ \\
\hline $\begin{array}{l}\text { Engklek } \\
\text { menara }\end{array}$ & \begin{tabular}{lcr} 
Anak & akan & \multicolumn{2}{c}{ melakukan } \\
permainan & engklek & secara \\
bergantian & sesuai & urutan \\
bernain.. & & \\
& & \\
& &
\end{tabular} & $\begin{array}{l}\text { Melatih anak agar mampu } \\
\text { mengambil keputusan, } \\
\text { melatih kesabaran, dan } \\
\text { pengendalian diri, } \\
\text { mengontrol emosi dengan } \\
\text { harus bisamengendalikan } \\
\text { responnya agar gaju tidak } \\
\text { jatuh dan lompatan tidak } \\
\text { terkena garis pembatas. } \\
\text { Anak juga belajar untuk } \\
\text { menunggu bergiliran untuk } \\
\text { main yang bisa melatih } \\
\text { penundaan kepuasan. }\end{array}$ \\
\hline
\end{tabular}


Ketek karet

Remind card

Anak akan diminta untuk mengisi tugas-tugas seperti mengurangi waktu bermain dan menuliskan kegiatan atau aktivitas lain selama waktu pengurangan berlangsung dalam waktu satu minggu.

Anak akan mengolah
informasi atau stimulus
yang diterima
peraturan yang $r$ ada.
Bagaimana anak dapat
melakukan hal tersebut
terkait dengan aspek
kognitif dalam kontrol diri.
Anak juga belajar untuk
mengambil keputusan dan
juga melatih kesabaran
dalam mengontrol
emosinya.

Kontrol Perilaku, Kontrol Kognitif, dan Kontrol Keputusan.

Dalam kegiatan ini anak akan belajar bagaimana ia mengontrol stimulus yang tersedia dan mengalihan dengan melakukan kegiatan positif lainnya, anak juga belajar mengontrol keputusan akan mengikuti sesuai tugas yang diberikan atau mebiarkannya.

Internet gaming disorder adalah salah satu bentuk gangguan terkait adiksi internet yang digunakan untuk bermain memainkan permainan yang terhubung oleh internet, berkaitan dengan berbagai dampak negatif dari game yang dimainkannya. Ciri utama dari internet gaming disorder yaitu menetap dan dilakukan berulang atau menerus.Faktor penyebab bisa digunakan sebagai media penarikan diri, dan juga bentuk dari coping.

Data penelitian diperoleh melalui instrumen model pengukuran skala. Arikunto (2002) menjelaskan bahwa instrumen penelitian adalah alat yang digunakan oleh peneliti dalam mengumpulkan data agar memudahkan pengerjaan dalam penelitian dan hasilnya lebih baik (dalam artian lebih cermat, sisematis, dan lengkap) sehingga menjadi lebih mudah untuk diolah. Instrumen yang digunakan dalam penelitian ini adalah adaptasi dari skala IGD20-test, yang digunakan sebelum (pretest) dan sesudah (post-test) diberikannya intervensi atau perlakuan. Skala ini didasarkan dari 9 kriteria atau simptom disorder dari DSM-V dan menggabungkan kerangka teoritis dari komponen adiksi (salience, mood modification, tolerance, withdrawal symptoms, conflict dan relapse). IGD 20-Test yang 
memiliki jumlah item 14 dengan indeks validitas 0,345-0,590 serta angka reliabilitas sebesar 0,83 .

Pada tahap persiapan atau pra-intervensi, peneliti melakukan pendalaman materi seperti pembuatan modul dan juga adaptasi alat ukur IGD 20-Test dan selanjutnya akan dilakukan simulasi. Proses adaptasi skala terlebih dahulu dilakukan dengan prosedur pengadaptasian yakni menterjemahkan bahasa ke bahsa indonesia, kemudian diterjemahkan lagi kebahasa asal skala hingga diperoleh kesamaan makna. Asesmen awal dilakukan peneliti dengan mewawancarai anak terkait penggunaan game internet Selanjutnya peneliti menyebar skala untuk memperoleh hasil pretest. Ketika hasil pretest telah diketahui, akan diseleksi subjek dengan melihat skor yang diperoleh berdasarkan norma kelompok, kemudian mengikuti kegiatan intervensi. Berikut adalah norma yang disajikan dalam tabel.

Tabel 3 kategori skala IGD-20 test

\begin{tabular}{cc}
\hline Skor & Kategori \\
\hline $14-28$ & Rendah \\
$29-40$ & Sedang \\
$41-70$ & Tinggi \\
\hline
\end{tabular}

Tahap Intervensi, peneliti memberikan perlakuan pada 6 anak kelompok eksperimen yaitu perlakuan berupa pelatihan yang dibagi menjadi dua sesi. Pada sesi pertama intervensionis/peneliti akan memberikan edukasi atau membantu identifikasi problem situasi yang dihadapi, emosi, serta bagaimana pikiran anak terhadap permasalah yang sedang dihadapi, mengidentifikasi/membagikan pengalam pribadi tentang apa saja faktor pendorong dan penghambat, serta ulasan tentang materi yang telah diberikan dengan memberikan waktu untuk tanya jawab dan mengerjakan lembar enaluasi kepada anak. Pada sesi kedua akan mengulas kembali materi sebelumnya secara singkat, meberikan materi dengan media video-video yang ditampilkan (akibat atau dampak dari penggunaan yang berlebih, bagaimana cara mengurangi dan mengatasi), setelah itu merangkum dengan memberikan list cara-cara yang sudah dipelajari, dan juga games. Pada akhir sesi kedua ini anak akan diberikan remind card yang berisi tugas-tugas yang dilakukan anak setelah diberi perlakuan. Setelah seminggu berlalu setelah sesi kedua peneliti akan mengambil kembali dan mengadministrasikan kembali alat ukur atau skala untuk dilakukannya post-test.

Tahap pasca-intervensi atau anlisa data, pada tahap ini peneliti menganalisa hasil dari data pretest dan post-test yang diperoleh. Data yang diperoleh diinput dan diolah menggunakan analisa Mann Whitney untuk masing-masing kelompok. Kemudian membandingkan perbedaan hasil skor pretest dan post-test dengan analisis Wilcoxon Signed Ranks Test. Peneliti juga mengikutsertakan data penunjang seperti hasil observasi dan hasil dari remind card. Setelah itu peneliti mengambil kesimpulan dari penelitian yang telah dilakukan.

\section{HASIL}


Setelah penelitian dilakukan, diperoleh beberapa hasil yang akan dipaparkan dengan tabel-tabel dan gambar bagan berikut. Tabel pertama merupakan deskripsi dari karakteristik subjek dalam pelatihan kontrol diri untuk mengurangi internet gaming disorder berdasarkan hasil sampling dengan metode purposive sampling. Subjek pada penelitian ini terbagi menjadi dua kelompok yaitu kelompok eksperimen dan kelompok kontrol.

Tabel 4 Deskripsi karakteristik Subjek

\begin{tabular}{llll}
\hline & Kategori & Kelompok Eksperimen & Kelompok Kontrol \\
\hline \multirow{2}{*}{ Usia } & Anak-anak & $10-11$ & $9-11$ \\
& Akhir & & 5 orang \\
Jenis Kelamin & Laki-laki & 4 orang & 1 orang \\
Rata-rata Skor & Perempuan & 2 orang \\
& & 44,00 & 44,67 \\
\hline
\end{tabular}

Berdasarkan tabel 2 di atas subjek yang menjadi peserta pelatihan adalah siswa yang termasuk dalam rentang anak-anak akhir. Pada kelompok eksperimen terdiri dari 6 anak yaitu 4 anak laki-laki dan 2 anak perempuan dengan rentang usia 10-11 tahun, sedangkan untuk kelompok kontrol terdiri dari 6 anak yaitu 5 laki-laki dan 1 perempuan dengan rentang usia 9-11 tahun.

Peneliti menganalisis skor pretest pada kedua kelompok tersebut dengan menggunakan uji Mann whitney untuk melihat kesetaraan kelompok sebelum diberikan perlakuan berupa pelattihan kontrol diri.

Tabel 5 Deskriptif Uji Mann-Whitney pada Data Pretest Kelompok Eksperimen dan Kelompok Kontrol

\begin{tabular}{lcccc}
\hline Kelompok & N & Mean Rank & Z & Asymp. Sig. \\
\hline Eksperimen & 6 & 6,17 &,- 328 &, 743 \\
Kontrol & 6 & 6,83 & & \\
\hline
\end{tabular}

Dari tabel 4 dapat diperoleh nilai Sig sebesar 0,74>0,05 yang menunjukkan tidak ada perbedaan sebelum diberi perlakuan. Hal tersebut menunjukan bahwa data awal pada kedua kelompok sama. Dengan demikian dapat disimpulkan bahwa kondisi kedua kelompok setara sebelum diberikan perlakuan pelatihan kontrol diri.

Selanjutnya peneliti melakukan uji analisis Mann Whitney untuk mengetahui apakah ada perbedaan dari kedua kelompok setelah diberikan perlakuan pelatihan kontrol diri.

Tabel 6 Deskripsi Uji Mann-Whitney pada Data Posttest Kelompok Eksperimen dan Kelompok Kontrol

\begin{tabular}{lcccc}
\hline Kelompok & N & Mean Rank & Z & Asymp. Sig. \\
\hline Eksperimen & 6 & 4,25 & $-2,189$ &, 029 \\
Kontrol & 6 & 8,75 & & \\
\hline
\end{tabular}


Berdasarkan hasil uji pada tabel 5 diperoleh hasil nilai $\mathrm{z}=-2,189$ dan nilai Sig $=0,029$ Sig < 0,05. Hal ini menandakan bahwa terdapat perbedaan yang signifikan pada kelompok eksperimen dan kelompok kontrol setelah diberikan perlakuan pelatihan kontrol diri. Tabel di atas juga menujukkan bahwa rata-rata skor dari kelompok ekperimen sebesar 4.25 lebih rendah dibandingkan dengan skor dari kelompok kontrol yang sebesar 8.75. Hal tersebut juga menunjukkan bahwa rata-rata skor pada kelompok eksperimen yang telah diberi perlakuan pelatihan kontrol diri lebih rendah jika dibandingkan dengan rata-rata skor kelompok kontrol yang tidak diberikan perlakuan.

Langkah terakhir untuk hasil penelitian, peneliti melakukan uji analisis Wilcoxon untuk mengetahui gambaran tingkat pada kedua kelompok di dua kondisi yang berbeda yaitu pretest dan posttest.

\section{Tabel 7 Deskripsi Uji Wilcoxon pada Data Pretest dan Posttest Kelompok Eksperimen dan Kelompok Kontrol}

\begin{tabular}{|c|c|c|c|c|c|}
\hline \multirow{2}{*}{ Kelompok } & \multirow{2}{*}{$\mathbf{N}$} & \multicolumn{2}{|c|}{ Rata-rata Skor } & \multirow{2}{*}{$\mathbf{Z}$} & \multirow{2}{*}{$\begin{array}{c}\text { Asymp. } \\
\text { Sig. }\end{array}$} \\
\hline & & Pretest & Posttest & & \\
\hline Eksperimen & 6 & 44,00 & 38,33 & $-2,032$ & 0.042 \\
\hline Kontrol & 6 & 44,67 & 44 &,- 378 & 0.705 \\
\hline
\end{tabular}

Berdasarkan hasil uji analisis Wilcoxon pada Tabel 6 pada kelompok eksperimen diperoleh hasil nilai Sig. $=0.042$, Sig. $<0.05$. Hasil tersebut menunjukkan adanya perbedaan yang signifikan pada skor pretest dan posttest kelompok eksperimen. Hasil tersebut juga menunjukkan bahwa perlakuan berupa pelatihan kontrol diri dapat memberikan efek pengaruh untuk mengurangi internet gaming disorder pada kelompok eksperimen yang telah diberi perlakuan. Sementara itu, berdasarkan hasil uji analisis Wilcoxon pada tabel 6 pada kelompok kontrol diperoleh nilai Sig. $=0.705$, Sig. $>0.05$. Hasil tersebut menunjukkan bahwa tidak terdapat perbedaan yang signifikan pada skor pretest dan posttest kelompok kontrol.

Dari hasil analisa kuantitatif yang dilakukan dapat disimpulkan bahwa perlakuan berupa pelatihan kontrol diri dapat digunakan sebagai media untuk mengurangi kecenderungan internet gaming disorder pada anak. Hasil penelitian juga menunjukkan bahwa skor pada kelompok eksperimen lebih rendah dibandingkan kelompok kontrol setelah diberikan perlakuan.

Hasil analisis data kuantitatif di atas didukung dengan hasil dari data remind card yang telah dikumpulkan pada kelompok eksperimen. Remind card ini digunakan untuk mengontrol berapa lama waktu durasi bermain game dan juga mengetahui jenis-jenis aktivitas fisik lain apa saja yang bisa mengalihkan kelompok eksperimen selain bermain game internet dalam setiap harinya selama satu minggu. Berikut hasil dari remind card. 


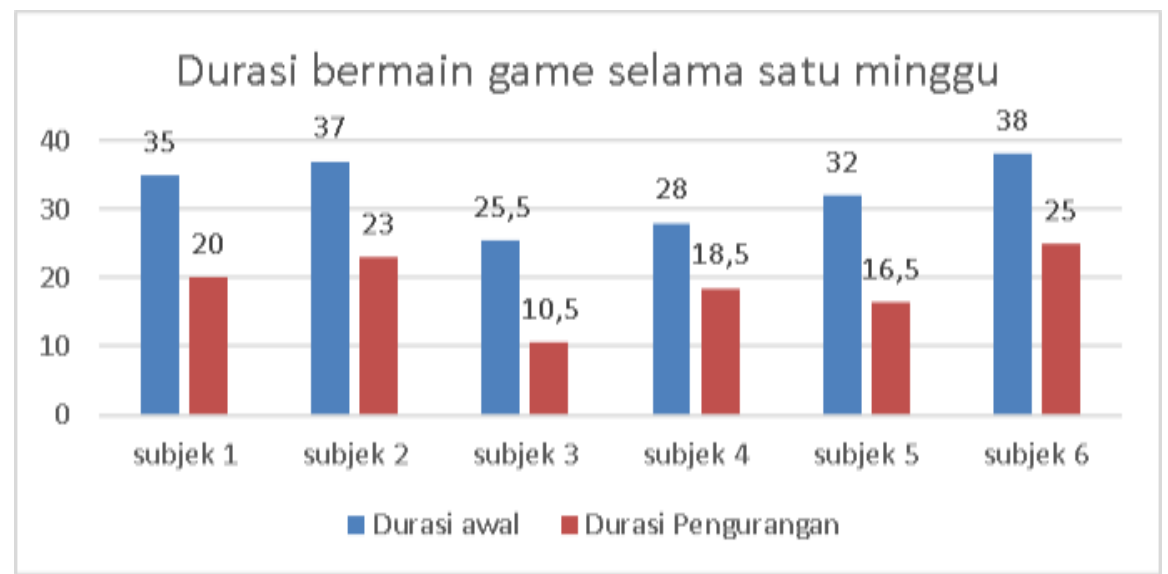

Gambar 1 Total durasi bermain game per jam dalam satu minggu

Dari gambar 1 menunjukkan hasil remind card selama satu minggu setelah diberikan pelatihan kontrol diri. ada gambar 1 terlihat adanya penurunan durasi bermain game dalam kurun waktu satu minggu pada anak kelompok eksperimen setelah diberikan perlakuan pelatihan kontrol diri. Hal ini menunjukkan bahwa setelah pelatihan kontrol diri anak mulai bisa mengontroldurasi dalam bermain game internet. Selanjutnya adalah gambaran aktivitas lain selain bermain game internet pada anak-anak kelompok eksperimen setelah diberikan perlakuan pelatihan kontrol diri.

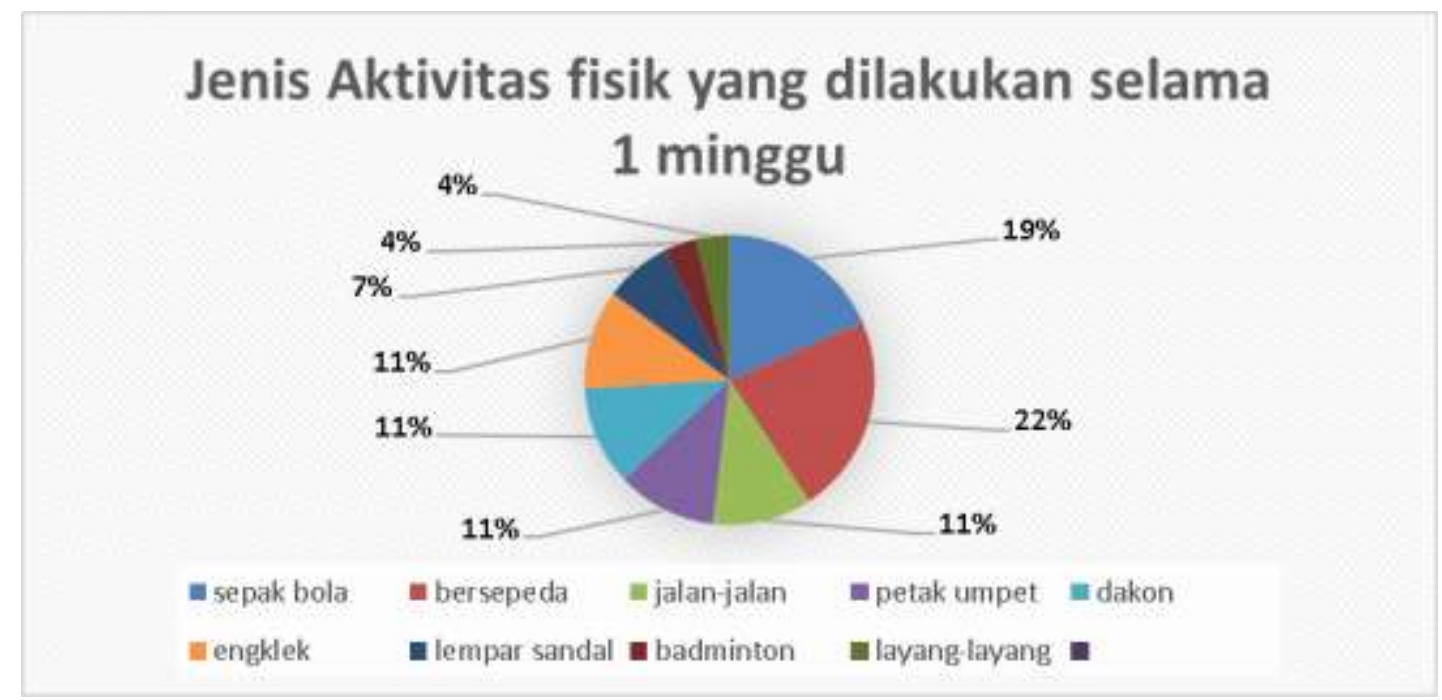

Gambar 2 Jenis aktivitas fisik yang dilakukan selama 1 minggu

Dari gambar 2 menunjukkan hasil remind card selama 1 minggu setelah diberikannya perlakuan pelatihan kontrol diri pada kelompok eksperimen. Dari gambar dapat dilihat bahwa sebagian besar anak melakukan kegiatan aktivitas fisik lain berupa bersepeda (22\%) untuk mengalihkan dari bermain game internet. Lalu selanjutnya ada sepak bola $(19 \%)$, bermain petak umpet (11\%), bermain engklek (11\%), bermain dakon (11\%), serta jalan-jalan (11\%). Hal ini dapat membiasakan anak melakukan aktivitas yang dapat mereka menguragi bermain game internet sehar-hari, terlebih melakukan aktivitas yang menyenangkan bagi anak-anak memfasilitasi dan mendorong anak untuk melakukan aktivitas diluar akan sedikit membantuuntuk tidak bergantung pada internet dan juga sebagai untuk mengontrol diri agar mengurangi dampak dari internet gaming disorder. 


\section{DISKUSI}

Pemaparan hasil analisa data yang telah dilakukan menunjukkan bahwa adanya pengaruh yang signifikan dari pelatihan kontrol diri yang dilakukan terhadap tingkat internet gaming disorder pada anak SDN Mojolangu 5. Pelatihan kontrol diri yang merupakan suatu metode intervensi untuk memberikan keterampilan pada individu agar bisa mengendalikan dorongan-dorongan yang ada dalam dirinya serta sekitarnya cukup efektif untuk mengurangi tingkat internet gaming disorder pada anak usia sekolah. Hal ini dibuktikan berdasarkan uji analisa data yang telah dilakukan menujukkan bahwa adanya perbedaan tingkat internet gaming disorder pada kelompok eksperimen dengan kelompok kontrol sebelum diberikan perlakuan (pretest) dengan setelah diberikan peelakuan (posttest). Kelompok eksperimen mengalami penurunan tingkat internet gaming disorder yang signifikan setelah diberikanya perlakuan berupa pelatihan kontrol diri dibandingkan dengan kelompok kontrol.

Internet gaming disorder merupakan sejenis perilaku adiksi yang didefinisikan sebagai perilaku kehilangan kontrol atau kendali, dan penggunaan game internet secara terusmenerus dan berulang yang memiliki ciri utama yakni penggunaan yang menetap untuk waktu yang lama.. Wartberg et al. (2016) menjelaskan bahwa terdapat hubungan yang signifikan antara internet gaming disorder dan remaja laki-laki, permasalah kontrol emosi. Penelitian yang dilakukan oleh Rho, Hyeseon, Taek-ho, Hyun, Dongjin, Dai-jin, \& In Young (2017) juga menunjukkan bahwa laki-laki lebih rentan untuk masuk dalam grup internet gaming diorder dibandingkan dengan perempuan. Hal ini seperti penelitian yang dilakukan bahwa subjek yang memeuhi kriteria dalam penelitian ini lebih banyak berjenis kelamin laki-laki dibandingkan dengan perempuan.

IGD sering menunjukkan gangguan pada kognitif yang berkaitan dengan perilaku impulsif yang meningkat, serta gangguan kontrol kognitif dan juga waktu.Secara khusus impulsifitas dan pengendalian diri merupakan faktor psikologis yang penting yang mempengaruhi kecanduan. Impulsifitas telah dilaporkan sebagai resiko untuk kecanduan seperti smartphone ataupun mengakses internet (Wu, Cheung, Ku, Hung, 2013) dan juga kontrol diri sering dikaitkan dengan kecanduan seperti substance use dan juga penggunaan internet (Park, Park, Shin, Li, Rolfe, Yoo, \& Dittmore, 2016). Dalam penelitian ini perlakuan yang dipilih untuk mengurangi internet gaming disorder adalah penggunakan pelatihan kontrol diri.

Pelatihan berkaitan dengan proses pembelajaran pada individu agar mendapatkan pengetahuan, ketarampilan, dan sikap yang dibutuhkan. Pelatihan yang diberikan dalam penelitian ini berfungsi untuk mengembangkan potensi yang ada dalam diri khususnya kontrol diri. Kontrol diri dapat dikembangkan melalui latihan sederhana dengan memfokuskan pada kegiatan yang secara langsung mempraktikkan pengontrolan diri dan mengerahkan kontrol diri serta kekuatan pengendalian (Muraven, 2010). Seperti halnya dengan pelatihan kontrol diri dalam penelitian ini, kegiatan yang terdapat dalam pelatihan ini menekankan pada pembelajaran langsung mengenai pengembangan kontrol diri melalui materi yang diberikan dan permainan-permainan yang dilakukan. 
Kontrol diri merupakan salah satu bagian terpenting yang terdapat dalam diri manusia karena memungkinkan individu untuk membatasi perilaku impulsif. Kontrol diri yang buruk akan menyebabkan individu melakukan banyak perilaku negatif seperti kriminalitas, perilaku seksual beresiko, penggunaan narkoba dan alkohol. Sebaliknya, pengendalian diri yang tinggi memberikan dampak yang positif seperti mengurangi psikopatologi, hubungan yang lebih baik, keterampilan interpersonal yang lebih baik, kontrol emosional yang lebih baik, serta dampak positif lainnya (Rho, Lee, \& Lee 2017). Dengan kata lain jika anak memiliki kontrol diri yang baik maka anak akan bisa mengontrol diri mereka agar bisa mengurangi dampak negatif dari penggunaan internet gaming yang berlebih.

Pelatihan menurut Michael (dalam Moejikat, 1991) menunjukkan setiap proses untuk mengembangkan bakat, keterampilan, dan kemampuan guna menyelesaikan pekerjaan tertentu dengan fokus kegiatannya adalah meningkatkan kemampuan untuk memenuhi kebutuhan pada masa sekarang. Pelatihan merupakan proses pembelajaran dalam meningkatkan pengetahuan, sikap, dan keterampilan. Keterampilan seseorang untuk mengatur dirinya sendiri mencakup kesadaran diri dan keterampilan diri salah satunya adalah kontrol diri. Seperti pelatihan kontrol diri yang dilakukan untuk membantu anak dalam melatih keterampila mengatur dirinya sendiri agar dapat mengurangi dampak penggunaan internet gaming.

Metode intervensi yang dilakukan dalam mengurangi internet gaming disorder ini menggunakan pelathan kontrol diri, yang didalamnya terdapat pemberian materi mengenai iinternet gaming dengan memberikan informasi materi salah satunya menggunakan media video yang akan membantu anak lebih mudah menyerap informasi yang didapatkan. Seperti yang dilakukan Shah, Mathur, Kathuria \& Gupta (2016) penelitian tersebut menyasar pada anak-anak yang menunggu di ruang tunggu dokter gigi. Pemberian video edukasi bertujuan untuk memberikan pengetahuan yang lebih baik tentang kesehatan mulut pada anak-anak tersebut. Hasil penelitiannya menunjukkan perbedaan yang signifikan antara subjek yang dipertontonkan video tersebut dengan yang tidak dipertontonkan. Hal tersebut menunjukkan bahwa pemberian informasi melalui video cukup efektif dalam menyasar kognitif anak.

Dalam pelatihan kontrol diri yang dilakukan juga menggunakan metode pembelajaran melalui bermain, permainan-permainan yang digunakan seperti engklek, ketek karet, estafet kelereng, dan juga mini games lain. Metode intervensi melalui metode pembelajaran menggunakan permainan pada anak Di masa kanak-kanak ini bermain sangatlah berperan penting dalam hal pembelajaran dan juga perkembangan, dengan bermain anak dapat mengeksplor dirinya mengenai lingkungan, bersosiallisasi dengan teman sebayanya dan juga memiliki banyak pengalaman (Khasanah, Prasetyo \& Rakhmawati, 2011).

Piaget dalam teorinya, mengklasifikasikan anak usia sekolah dasar ke dalam tahapan pola bermain social play games with rules $( \pm$ 8-11 tahun). Dalam buku yang ditulis oleh Iswinarti (2017) anak pada usia sekolah dasar akan memperoleh nilai kompetensi sosial dari permainan yang dimainkan. Anak mulai pandai berinteraksi sosial dan bermain 
dengan teman sebayanya serta mentaati aturan permainan, dan yang paling bagus adalah ketika anak bisa memainkan permainan dengan teman-temannya dengan menggunakan aturan yang dibuat sendiri, dan anak berusaha untuk mematuhinya, dan ketika ada kesalahan mereka bisa menerima sanksi yang diberikan. Dalam penelitian ini anak akan belajar lebih cara mengendalikan dirinya lewat permainan yang diberikan saat pelatihan terlihat dari cara anak yang mengikuti aturan permainan, menunggu giliran bermain, dan anak mengendalikan emosinya seperti mengumpat, marah, menyalahkan teman, jengkel kepada teman, dan sebagainya. Anak juga akan belajar bagaimana cara mengambil keputusan dan problem solving.

Penggunaan remind card di akhir intervensi eksperiman juga merupakan tambahan yang cocok untuk mengidentifikasi sejauh mana anak mengontrol dirinya dalam sehari-hari agar tidak bermain game internet dengan mengalihannnya melakukan kegiatan fisik atau kegiatan lain. Remind card juga sekaligus berfungsi sebagai reinforcement untuk anak melakukan hal lain selain bermain game internet. Konsep ini sudah digunakan pada mini riset yang dilakukan peneliti dan kawan-kawan tentang adiksi gadget pada anak-anak di Kelurahan Blimbing pada akhir tahun 2017. Hasil pengisian dapat membuktikan bahwa kegiatan fisik dapat dilakukan saat anak diberikan tugas untuk tidak bermain game internet. Pemberian rentang waktu dalam satu minggu juga dapat mebiasakan anak untuk memiliki aktivitas lain selain hanya bermain internet.

Menurut Piaget (Ormord, 2010) anak-anak dapat mengonstruksi keyakinan dan pemahaman-pemahaman mereka berdasarkan pengalaman yang telah diperolehnya. Menurut Anderson \& Krathwohl (Suwarto, 2010) terdapat beberapa kategori proses dalam belajar. Kategori pertama yaitu mengingat (remembering) merupakan proses yang sangat berhubungan denagn proses daya ingat tentang materi yang diberikan. Pada proses remembering ini terdapat dua proses kognitif yang berkaitan yaitu anak akan menyadari dan mengingat kembali. Setelah itu anak akan memahami (understanding), seorang anak dapat memahami jika ia dapat menarik suatu pesan dari materi yang telah disampaikan. Proses selanjutnya yaitu penerapan (applying), pada tahap ini anak akan menerapkan apa yang mereka peroleh kedalam perilaku. Pada penelitian ini anak menerapkan apa yang mereka peroleh dari pelatihan kontrol diri kedalam permainan yang ada dalam pelatihan serta dalam tugas-tugas dalam remind card yang telah diberikan.

Yusuf (2006) menyatakan bahwa kognitif manusia terdiri dari tiga bagian yaitu: (1) input, yaitu merupakan stimulus yang didapatkan dari lingkungan yang nantinya akan memasuk ke panca indra manusia (penglihatan, suara dan rasa); (2) Proses, dimana dalam hal ini pengolahan informasi yang dilakukan oleh otak dengan cara yang beragam, dengan tahapan meliputi pengolahan atau penyusunan informasi ke dalam bentuk-bentuk simbolik, membandingkan sesuatu dengan informasi sebelumnya, memasukan ke dalam memorinya dan menggunakannya apabila diperlukan; (3) Output, yaitu hasil yang diperoleh dari tahapan yang berbentuk tingkah laku. Dalam penelitian ini anak menangkap informasi melalui pemberian materi serta anak memahami materi yang diberikan kemudian melakukannya dalam bentuk perilaku yang dimunculkan dalam tugas remind card yakni pengurangan jumlah penggunaan game internet dengan melakukan bermain permainan atau aktivitas fisik lain. 
Graham (Simatupang, 2005) berpendapat bahwa bermain merupakan tingkah laku dari motivasi intrinsik yang dipilih secara bebas, anak melakukan kegiatan karena memang keinginan pribadi, bukan karena orang lain. Raharjo (2007) menyebutkan selain motivasi intrinsik, salah satu karakteristik bermain yakni fleksibel. Anak akan bebas beralih dari aktivitas satu ke aktivitas yang lain dengan mudah dan fleksibel. Dalam penelitian ini terlihat dari remind card yang telah terisi pada tugas pertama terdapat perbedaan tiap anak dalam kelompok eksperimen dalam pengurangan waktu bermain game internet selama satu minggu. Pengurangan waktu bermain game internet tersebut dipengaruhi oleh motivasi intrinsik tiap anak yang berbeda. Hal ini juga berkaitan dengan tugas kedua dalam remind card yakni menuliskan alasan pengurangan waktu bermain game internet dengan melakukan aktifitas sisik lainnya dengan jawaban yang variatif pada tiap anak. Anak-anak pada kelompok eksperimen dengan fleksibel beralih dari bermain game internet menjadi permainan atau aktifitas fisik lainnya.

Ketika anak diberikan media pembelajaran yang menarik untuk dilakukan, anak akan antusias untuk melakukannya secara berulang-ulang Pada masa kanak-kanak, anak banyak berinteraksi dengan teman sebaya melalui kegiatan bermain (Santrock, 2011). Pada penelitian ini, anak diberikan tugas pada akhir pelatihan kontrol diri dalam bentuk menuliskan aktivitas fisik lain bisa berupa permainan yang dapat dimainkan dengan teman sebayanya sehingga anak akan mampu mengurangi penggunaan game internet yang berlebihan. Hasil penelitlian menunjukkan bahwa adanya perubahan hasil internet gaming disorder pada kelompok eksperimen Berdasarkan uji analasis yang dilakukan, terdapat perbedaan yang signifikan pada kedua kelompok setelah diberi perlakuan yaitu $\mathrm{p}=0.042$, dimana nilai $\mathrm{p}<0.05$. hasil tersebut membuktikan bahwa pelatihan kontrol diri ini merupakan suatu perlakuan yang mampu digunakan untuk mengurangi internet gaming disorder pada anak usia 9-11 tahun.

Dengan berbagai kelebihan dan keberhasilan perlakuan yang dilaksanakan, bukan berarti penelitian ini tidak luput dari kekurangan. Masih ada kekurangan dan kelemahan yang perli digarisbawahi agar penelitian kedepannya mendapatkan hasil yang lebih baik. Kekurangan tersebut dimulai dari pemilihan subjek pada tahapan pra-eksperimen atau persiapan sebelum dilakukannya perlakuan. Ada baiknya jika dilakukan secara acak atau random assigment yang sesuai dengan prosedur dalam proses menentukan mana subjek yang masuk dalam kelompok eksperimen dan kontrol. hal tersebut bisa dilakukan dengan pengocokan undian karena konsep dari random assigment adalah seluruh subjek yang memenuhi kriteria berhak berada dalam kelompok eksperimen maupun kelompok kontrol. Juga dalam pengisian remind card sebagai monitoring yang menurut peneliti belum terlaksana dengan baik karena selain pengisian yang tidak dibarengi oleh orangtua, terdapat beberapa anak yang memiliki jadwal kegiatan yang padat yaitu selain sekolah anak juga mengikuti bimbel sehingga beberapa anak yang mengisi tugas tentang aktivitas fisik lain yang dilakukan dalam seminggu hanya seadanya saja.

\section{SIMPULAN DAN IMPLIKASI}

Penelitian ini mencoba mengetahui pengaruh dari pemberian eksperimen pelatihan kontrol diri terhadap anak usia 9-11 tahun yang memiliki tingkat internet gaming 
disorder yang tinggi. Temuan yang dihasilkan dari rangkaian penelitian ini menunjukkan bahwa terdapat pengaruh yang signifikan dari pemberian perlakuan berupa pelatihan kontrol diri terhadap kelompok eksperimen. Melalui metode pelatihan kontrol diri ini diharapkan anak mampu mengurangi tingkat internet gaming disorder sehingga anak terhindar dari dampak yang ditimbulkan dari penggunaan game internet yang berlebihan. Implikasi dari penelitian ini meliputi bagi orangtua, diharapkan untuk selalu mendampingi anak dalam menggunakan perangkat elektronik dan internet khususnya untuk bermain video game serta memberikan batasan waktu dalam menggunakannya agar anak terhindar dari dampak negatif yang ditimbulkan. Orangtua juga dapat memberikan alternatif permainan yang melibatkan aktivitas fisik agar anak dapat mengalihkan penggunaan game internet yang berlebihan seperti engklek, bersepeda, dan sepak bola bersama teman di sekitar rumah. Peneliti selanjutnya, disarankan dalam pembagian kelompok eksperimen dan kelompok kontrol yang dilakukan secara acak atau random assigment, selain itu peneliti dapat melakukan penelitian diberbagai daerah lainnya agar tidak terbatas di daerah Malang, sehingga metode ini dapat menjadi acuan mengurangi internet gaming disorder.

\section{REFERENSI}

Afiatin, T., Sonjaya, J. A., \& Pertiwi, Y. G. (2013). Mudah \& sukses menyelenggarakan pelatihan, melejitkan potensi diri. Yogyakarta: Kanisius

American Psychiatric Association. (2013). Diagnostic and statistical manual of mental disorders (5th ed.). Arlington, VA: American Psychiatric Association.

Arikunto, S. (2002). Prosedur penelitian suatu pendekatan praktik. Jakarta: Rineka Cipta.

Bargeron, A. H., \& Hormes, J. M. (2016). Psychososial correlates of internet gaming disorder: Psychopatology, life satisfaction, and impulsivity. Journal of Computers in Human Behavior, 68, 388-394.

Chaplin, J. P. (2006). Kamus lengkap psikologi. Jakarta : PT. Raja Grafindo.

Edralin, D. M. (2004). Training : a Strategic HRM Fuction. Retrieved Maret 21, 2018, from www.dlsu.edu.ph

Gentile, D. (2009). Pathological video-game use among youth ages 8 to 18: A national study. Journal of Psychological Science, 20, 594-602. Retrieved February 27, 2018, from doi:10.1111/psci.2009.20.issue-5

Ghufron, M. N., \& Risnawita, R. (2010). Teori-teori psikologi. Jogjakarta : AR-Ruzz Media.

Griffiths, M. D., \& Pontes, H. M. (2015). Addiction and entertainment products. In R. Nakatsu, M. Rauterberg, \& P. Ciancarini (Eds.), Handbook of digital games and entertainment technologies (pp. 1-22). Singapore: Springer. 
Griffiths, M. D., \& Wood, R. (2000). Risk factor in adolescence: The case of gambling, videogame playing, and the internet. Journal of Gambling Studies, 16, 199-225.

Iswidharmanjaya, D. (2011). Bila si kecil bermain gadget: Panduan bagi orang tua untuk memahami faktor-faktor penyebab anak kecanduan gadget. Google Book.

Iswinarti. (2017). Permainan Tradisional: Prosedur dan Analisis Manfaat Psikologis. Malang : UMM Press.

Janah, M. R. (2014). Pengaruh pelatihan kontrol diri dengan menggunakan metodetehnik gerakan mengontrol perilaku merokok (TGMPM) untuk mengurangi perilaku merokok pada siswa SMK Harapan Kartasura. Talenta Psikologi, 3, 79-99.

Khasanah, I., Prasetyo, A., \& Rakhmawati, E. (2011). Permainan tradisional sebagai media stimulasi aspek perkembangan anak usia dini. Jurnal Penelitian PAUDIA, 1(1), 91-105.

Kuss, D. J. (2013). Internet gaming addiction: Current perspectives. Psychology Research and Behavior Management, 6, 125-137.

Latipun. (2002). Psikologi eksperimen. Malang: Universitas Muhammadiyah Malang press.

Muraven, M. (2010). Building self-control strength: Practicing self-control leads to improved self-control performance. Journal of Experimental Social Psychology, $46,(2), 465-468$.

Navarona, A. I. (2016). Hubungan antara Praktek Unsafe Action dalam penggunaan gadget dengan keluhan subyektif gangguan kesehatan mata pada murid Sekolah Dasar Islam Tunas Harapan tahun 2016. Retrieved October 31, 2017, from http://mahasiswa.dinus.ac.id/

Park, J. A., Park, M. H., Shin, J. H., Li, B., Rolfe, D.T., Yoo, J. Y., Dittmore, S.W. (2016). Effect of sports participation on internet addiction mediated by selfcontrol: A case of korean adolescents. Kasetsart J. Soc. Sci., 37, 164-169.

Pebriana, P. H. (2017). Analisis penggunaan gadget terhadap kemampuan interaksi sosial pada anak usia dini. Jurnal Obsesi, 1, (1), 1-11.

Peeters, M., Koning, I., \& Eijnden, R. (2017). Predicting internet gaming disorder symptommps in young adolescents: A one-year follow-up study. Journal of Computers in Human Behavior. Retrieved Maret 2, 2018, from doi: 10.1016/j.chb.2017.008

Rho, M. J., Lee, H., Lee, T. H., Cho, H., Jung, D., Kim, D., \& Choi, I. Y. (2017). Risk factor for internet gaming disorder : Psychological factors and internet gaming characteristics. International Journal of Enviromental Research and Public Health. 
Rodriguez, A., Griffith, M. D. (2017). The treatment of internet gaming disorder: a brief overview of the PIPATIC program. Journal Mental health Addiction.

Rohmah, C. O. (2017). Pengaruh penggunaan gadget dan lingkungan belajar terhadap minat belajar siswa kelas XI kompetensi keahlian administrasi perkantoran SMK Muhammadiyah 2 Yogyakarta. Skripsi. Yogyakarta : Universitas Negeri Yogyakarta.

Santrock, J. W. (2011). Life-span development (13th ed). Jakarta : Erlangga.

Shah, N., Mathur, V. P., Kathuria, V., \& Gupta, T. (2016). Effectiveness of an educational video in improving oral health knowledge in a hospital setting. Indian Journal of Dentistry.

Simatupang, N. (2005). Bermain sebagai upaya dini menanamkan aspek sosial bagi siswa sekolah dasar. Jurnal Pendidikan Jasmani Indonesia, 3.

Sioni, S. R., Burleson, M. H., \& Bakerian, D. A. (2017). Internet gaming disorder: social phobia and identifying with your virtual self. Journal of Computers in Human Behavior, 71, 11-15.

Sugiyono. (2014). Metode penelitian pendidikan pendekatan kuantitatif, kualitatif dan $R \& D$. Bandung: Alfabeta.

Suwarto. (2010). Dimensi pengetahuan dan dimensi proses kognitif dalam pendidikan. Jurnal Pendidikan. 19,76-91.

Tangney, J. P., Baumeister, R. F., \& Boone, A. L., (2004). High self-control predicts good adjustment, less pathology, better grades, and interpersonal success. Journal of personality, 72, 271-322.

Wartberg, L., Kriston, L., Kramer, M., Schwedler, A., Lincoln, T., \& Kammerl, R. (2016). Internet gaming disorder in early adolescence: Associations with parental and adolescent mental health. European Psychiatry. Retieved Maret 2, 2018, from http://dx.doi.org/10.1016/j.eurpsy.2016.12.013

Wu, A. M., Cheung, V. I., Ku, L., Hung, E. P. (2013). Psychological risk factors of addiction to social networking sites among chinese smartphone users. Journal of Behavior Addiction, 2, 160-166.

Young, K. (2009). Understanding online gaming addiction and treatment issues for adolescents. The American Journal of Family Therapy, 37, 355-372.

Yusuf, S. (2010). Psikologi perkembangan anak dan remaja. Bandung: PT. Remaja Rosdakarya. 


\title{
GAMBARAN CITRA TUBUH PADA WANITA DEWASA AWAL YANG MENGALAMI OBESITAS
}

\author{
M. Luthfi Fernando \\ Program Studi Psikologi Profesi Fakultas Psikologi, Universitas Airlangga \\ m.luthfi.fernando-2016@psikologi.unair.ac.id
}

\begin{abstract}
Abstrak. Citra tubuh adalah ide seseorang mengenai penampilannya dihadapan orang lain. Umumnya wanita memiliki perhatian lebih dalam menjaga penampilanya. Obesitas adalah suatu masalah yang ditakuti wanita dan dapat berdampak pada masalah psikologis dan kesehatan. Tujuan penelitian ini mengetahui gambaran citra tubuh pada wanita dewasa awal yang mengalami obesitas. Metode penelitian yang digunakan adalah pendekatan kualitatif studikasus dengan pada satu orang. Metode pengumpulan data menggunakan observasi, wawancara, dan kuesioner yang mengukur gambaran citra tubuh. Hasil penelitian menunjukkan subjek memiliki kebiasaan pola makan berlebihan dan kurang gerak tubuh sehingga memiliki dampak seperti gangguan psikososial: rasa rendah dan menarik diri, gangguan kesehatan: mudah lelah/mengantuk dan kesulitan keseimbangan. Adapun citra tubuhnya secara keseluruhan mengangggap fisik tidak menarik, kesulitan menyesuaikan diri, namun tidak melakukan usaha konsisten mengevaluasi penampilan sehingga disarankan melakukan konsultasi kesehatan dan psikologis.
\end{abstract}

Kata Kunci: Citra tubuh, Wanita Dewasa Awal, Obesitas

Abstract. Body image is someone's idea about his appearance before other people. Generally women have more attention in maintaining their appearance. Obesity is a problem that women fear and can have an impact on psychological and health problems. The purpose of this study is to describe body image in early adult women who are obese. The research method used was a qualitative approach to casestudy with one person. Methods of collecting data using observations, interviews, and questionnaires that measure the picture of body image. The results showed subjects had a habit of overeating and lacking gestures so that they had an impact such as psychosocial disorders: feeling of inferiority and withdrawal, health problems: fatiguel sleepiness and balance difficulties. The overall body image is physically unattractive, difficulty adjusting, but does not make a consistent effort to evaluate appearance so it is advisable to conduct health and psychological consultations.

Keywords: Body image, Early Adult Woman, Obesity 
Obesitas atau kegemukan merupakan suatu masalah yang ditakuti oleh para wanita. Papalia dan Olds (1995) mengatakan bahwa obesitas atau kegemukan terjadi jika individu mengkonsumsi kalori yang berlebihan dari yang mereka butuhkan. Secara umum obesitas adalah kelebihan berat badan yang jauh melebihi berat badan normal. Seseorang yang memiliki berat badan $20 \%$ lebih tinggi dari berat badannya yang normal dianggap mengalami obesitas. Wanita memiliki lemak tubuh yang lebih banyak dibandingkan pria, dimana perbandingan yang normal antara lemak tubuh dan berat badan adalah sekitar $25-30 \%$ bagi wanita dan $18-23 \%$ pada pria. Seorang wanita dikatakan obesitas apabila lemak pada tubuhnya lebih dari $30 \%$ dan pria memiliki lemak lebih 25\% (Wikipedia, 2007). Metode yang paling berguna dan banyak digunakan untuk mengukur tingkat obesitas dan overweight adalah Indeks Massa Tubuh (IMT) atau Body Mass Index (BMI). Berdasarkan World Health Oganization (WHO) seseorang dikatakan overweight jika hasil IMT sebesar 25,0 - 29,9, sedangkan seseorang dapat dikatakan obesitas jika hasil IMTnya sebesar 30,0 - 34,9 (Aru .W Sudoyo, 2006).

Beberapa penyebab dari terjadinya obesitas adalah dikarenakan terlalu sedikitnya aktifitas fisik dan juga disebabkan karena kebiasaan makan yang berlebihan. Program pengurangan berat badan yang menggunakan teknik modifikasi perilaku untuk membantu orang yang obesitas membuat perubahan dalam makanan dan latihan menunjukkan kesuksesan. Akan tetapi, faktor genetik dan lainnya yang sama sekali tidak berkaitan dengan kemauan dan pilihan gaya hidup membuat sebagian orang rawan terhadap obesitas. Termasuk pula diantara faktor ini regulasi metabolisme yang salah, ketidakmampuan mengenali sinyal tubuh akan rasa lapar dan kenyang, dan perkembangan jumlah sel lemak yang abnormal (Papalia, 2008).

Dampak buruk obesitas terhadap kesehatan, sangat berhubungan dengan berbagai macam penyakit yang serius, seperti tekanan darah tinggi, jantung, diabetes melitus, dan penyakit pernapasan. Dampak lain yang sering diabaikan adalah perasaan merasa dirinya berbeda atau dibedakan dari kelompoknya akan membuat individu dengan obesitas rentan terhadap berbagai masalah psikologis. Penelitian Daniel (1997) memperlihatkan bahwa ada hubungan yang sangat erat antara psikologis dengan obesitas pada wanita, terutama dalam bentuk depresi. Wanita obesitas yang dijauhi oleh teman-temannya memiliki kecenderungan untuk mengalami rasa putus asa yang besar. Hubungan antara obesitas dengan gejala psikologis merupakan suatu lingkaran yang tidak terputus. Seseorang yang mengalami obesitas akan mudah merasa tersisih atau tersinggung. Hal ini akan lebih parah bila ia mengalami kegagalan dalam pergaulan. Seseorang yang obesitas akan cenderung dicap sebagai orang yang susah bergaul dan mudah tersinggung. Orang yang obesitas akan mencap sebagian dari temannya sebagai orang yang suka mengolok-olok. Masalah psikologis yang paling umum didapatkan adalah cemas, ganggguan makan. Depresi pada obesitas dapat muncul karena pertentangan batin antara keinginan untuk memperoleh bentuk tubuh yang ideal dan kenyataan yang ada. Depresi terjadi sebagai akibat gangguan citra tubuh (sering berupa distorsi, bila melihat didepan cermin, seseorang tidak melihat tubuhnya sebagaimana adanya dalam realitas).

Bagi orang yang mengalami obesitas, masalah yang sering kali muncul adalah kepercayaan diri yang rendah. Hal ini sejalan denga hasil yang ditemukan di studi awal : “....untuk penampilan saya biasa nya sih jujur kadang-kadang itu minder, kadang-kadang 
ga percaya diri juga dihadapan orang, ya terkadang juga di ejek-ejek sama teman-teman" (Komunikasi Personal, 10 Apri 2018). Wanita yang menderita obesitas selalu dijadikan sebagai objek ejekan dan penampilan yang gemuk selalu di ejek dan dianggap sebagai hal yang lucu yang dapat membuat orang lain tertawa dan dianggap jelek (Dewi, 2004). Kenyataan ini dapat membuat penderita obesitas merasa dirinya sangat berbeda dan aneh dibandingkan dengan orang lain. Tubuh yang kurus bukan hanya dianggap menarik, tetapi tubuh yang gemuk dianggap sesuatu yang memalukan (Silverstein, Perdue, Petersor dan Kelly, 1986).

Orang yang obesitas memiliki kesulitan dalam hal perkembangan dan identitas (Sheshowsky,1983). Obesitas juga dapat menimbulkan masalah sosial bagi wanita (Kaplan, 1999). Dalam dunia sosial menunjukkan bahwa kecantikan dan ketertarikan merupakan hal yang membuat wanita dapat menarik perhatian lawan jenis dan lingkungan nya. Hal ini sesuai dengan tugas perkembangan dewasa awal yaitu memilih pasangan (Hurlock, 1980). Semua orang tentu saja ingin menampilkan sebuah tampilan fisik yang menarik, agar dapat menarik perhatian lawan jenisnya termasuk para wanita dewasa awal. Bagi seorang yang bentuk tubuhnya kurang ideal, sering sekali menolak kenyataan perubahan fisiknya sehingga mereka tampak mengasingkan diri karena merasa minder.

Agustiani (2006) mengatakan bahwa penilaian negatif individu pada dirinya akan menimbulkan perasaan tidak berdaya, artinya seseorang individu mempersepsi adanya kekurangan dalam segi fisik, tampilan yang tidak menyenangkan dan secara sosial tidak adekuat. Perasaan seperti ini tentu saja akan menghambat penyesuaian dirinya. Ketidakpuasan terhadap tubuh berhubungan dengan ketidak cocokan antara persepsi dan keinginan untuk memperoleh bentuk dan ukuran tubuh tertentu (Bosiet et al,.2006). Ketidak puasan ini yang pada akhirnya membuat wanita menjadi tidak percaya diri dan menganggap penampilannya sebagai sesuatu yang menakutkan.

Berdasarkan pemaparan diatas maka peneliti tertarik untuk meneliti bagaimana gambaran citra tubuh yang akan dilihat dari evaluasi penampilan, orientasi penampilan wanita dewasa awal yang mengalami obesitas sehingga nantinya hasil penelitian dapat memberikan manfaat referensi bagi wanita dewasa awal yang mengalami obesitas agar mendapatkan gambaran mengenai citra tubuhnya, kemudian bagi pihak keluarga agar dapat memberikan informasi tentang citra tubuh sehingga dapat membantu usaha evaluasi diri penyandang obesitas. Hal ini bertujuan agar wanita yang mengalami obesitas dapat menerima dan mengevaluasi keadaan tubuh atau fisiknya secara positif dan lebih baik.

\section{METODE}

Penelitian ini menggunakan pendekatan kualitatif perspektif studi kasus dengan variabel citra tubuh sebagai variabel penelitian yang ingin diteliti secara lebih mendalam. Penelitian kualitatif merupakan metode-metode untuk mencari jawaban atas suatu pertanyaan, dilakukan secara sistematik menggunakan seperangkat prosedur untuk menjawab pertanyaan, mengumpulkan fakta, menghasilkan suatu temuan yang tidak bisa 
ditetapkan sebelumnya, dan menghasilkan suatu temuan yang dapat dipakai melebihi batasan-batasan penelitian yang ada pada penelitian kuantitatif. Penelitian kualitatif digunakan untuk memahami suatu masalah penelitian dari sudut pandang/ perspektif populasi penelitian yang terlibat (Saryono, 2011). Perspektif studi kasus adalah studi yang mengekplorasi suatu masalah dengan batasan terperinci, memiliki pengambilan data yang mendalam, dan menyertakan berbagai informasi (Saryono, 2011). Dalam kaitannya dengan penelitian ini yaitu penulis ingin meneliti bagaimana gambaran citra tubuh wanita dewasa awal yang mengalami obesitas. Penulis ingin meneliti secara intensif dengan tujuan untuk memberikan gambaran-gambaran secara mendetail tentang gambaran citra tubuh yang dilihat dari evaluasi penampilan, orientasi penampilan wanita dewasa awal yang mengalami obesitas. Adapun tempat lokasi penelitian ini dilakukan dibanjarmasin.

Subjek dalam penelitian kualitatif ini disebut dengan subjek. Jumlah subjek yang terlibat dalam penelitian ini sebanyak satu orang, didapatkan dengan menggunakan purposif sampling yang memiliki kriteria; usia berkisar antara 21 sampai dengan 30 tahun, mengalami obesitas dengan IMT (Indeks masa tubuh) minimal sebesar 30,0 - 34,9. Pengumpulan data dilakukan dengan metode wawancara mendalam (in depth interview). Prosedur wawancara dilakukan dengan mengacu pada panduan wawancara yang dibuat oleh peneliti berdasarkan demensi citra tubuh oleh Cash (2004). Panduan wawancara yang dibuat adalah dalam bentuk pertanyaan terbuka dimana subjek penelitian dapat menjawab bebas semua pertanyaan yang diajukan oleh peneliti. Wawancara yang dilakukan bersifat semi terstruktur yang berarti bahwa peneliti tidak hanya menanyakan hal-hal yang ada di panduan wawancara saja tetapi pertanyaan lain dapat diajukan oleh peneliti mengikuti respons yang diberikan oleh subjek untuk dapat menggali data lebih dalam. Penelitian ini juga menggunakan observasi untuk melihat secara langsung bagaimana subjek menggambarkan citra tubuhnya dalam sehari-hari, ditambah dengan tes informal (kuisioner yang telah di uji validitas dan reliabilitasnya untuk mengukur citra tubuh sehingga dapat menambah informasi selain dari sumber utama yaitu wawancara. Adapun tehnik analsis data yang digunakan dalam penelitian ini adalah dengan mencari dan menyusun secara sistematis data yang diperoleh dari hasil wawancara, observasi, dan tes informal, sehingga kemudian diorganisasikan datanya lalu dijabarkan kedalam unit-unit demensi citra tubuh kemudian dilakukan sintesa dengan hasil temuan untuk dipilih mana yang penting dan yang akan dipelajari dan dibuat kesimpulan secara keseluruhan dari hasil penelitian.

\section{HASIL}

A. Hasil Asesmen

1. Identitas Subjek/Identitas Kasus
a. Nama
: MA
b. Jenis Kelamin
: Perempuan
c. Usia
d. Berat badan
: 23 Tahun
e. Tinggi Badan
: $105 \mathrm{Kg}$
f. Status dalam Keluarga
: $170 \mathrm{Cm}$
: Anak ke-2 dari 3 saudara 
2. Riwayat Kasus

a. Riwayat Perkembangan dan Kesehatan

Selama ini belum pernah/ belum terdiagnosa penyakit berat. Namun sudah terlihat dampak seperti gangguan saluran pernafasan terbukti dari hasil wawancara yang subjek ungkapkan bahwa subjek sering mengantuk dan menurut signifikan others terkadang subjek tidur dengan mengorok.

b. Riwayat Keluarga dan Tempat Tinggal

Tempat tinggal Desa Dahai, Kecamatan Paringin, KAB. Balangan dan Sekarang tinggal di banjarbaru sendirian dan kos terpisah dari orang tua untuk kuliah, subjek anak ke 2 dari 3 saudara dan menjadi satu-satu nya anggota keluarga yang mengalami obesitass.

\section{Hasil Wawancara}

Berdasarkan hasil tiga kali wawancara yang telah dilakukan dengan subjek sebanyak 2x pada tanggal 24 April 2018 pukul 16.30-17.00, 31 April 2018 pukul 12.00 -12.20 dan pada signifikan others sebanyak 1x pada tanggal 27 April 2018, 12.00-12.20, didapatkan hasil bahwa subjek bernama MA yang berusia 23 tahun menyatakan dia mengukur evaluasi dari penampilan dan keseluruhan bentuk tubuh nya adalah tidak menarik. Sebenarnya subjek memiliki keinginan untuk memiliki penampilan yang menarik, tapi kelebihan berat badaan nya menyulitkan subjek mencari pakaian yang sesuai dengan bentuk tubuhnya, sehingga kepercayaan diri subjek di hadapan orang lain rendah, subjek merasa minder dan malu di hadapan orang-orang yang tidak dikenalnya tetapi untuk dihadapan teman-teman nya subjek mengungkapkan kepercyaan dirinya tidak terganggu karena sudah adanya penerimaan terhadap dirinya oleh teman-temannya.

Untuk perhatian individu terhadap penampilannya dan usaha yang dilakukan untuk memperbaiki dan meningkatkan penampilannya subjek menyatakan bahwa lebih suka memakai pakaian yang longgar karena menurut nya jika memakai pakaian yang ngepas ditubuhnya akan menampakkan bentuk tubuh gemuknya, tapi subjek masih merasa tidak cocok dengan pakaian yang biasa dia gunakan karena menurutnya pakaian yang biasa digunakannya masih agak kekecilan/ngepas ditubuh dan tidak longgar, hal ini senada dengan yg di ungkapkan signifikan others pada saat wawancara bahwa subjek biasa masih memakai pakaian yang ngepas karena subjek kesulitan mencari pakaian yang sesuai dengan bentuk tubuhnya dan subjek juga mengungkapkan halnya demikian, hal ini juga yang menyebabkan subjek tidak dapat mengikuti fashion wanita zaman sekarang agar dapat memperbaiki penampilannya karena menurutnya pakaian yang modis zaman sekarang tidak menyediakan bentuk ukuran besar biasanya hanya sampai seperti ukuran M saja, subjek juga mengungkapkan bahwa subjek tidak dapat mengikuti model hijab zaman sekarang karena subjek mudah kepanasan karena badannya yang besar, subjek juga menyatakan bahwa subjek malas untuk berolahraga agar menguruskan badannya ataupun untuk kesehatannya walaupun sudah sering mendapat dorongan dari teman-temannya, dan menurut signifikan others subjek pernah melakukan usaha berolahraga, seperti lari pagi setiap hari minggu, bermain 
hula-hup dengan rutin, pernah ikut yoga,bahkan meminum obat pelangsing namun semuanya usaha gagal begitu saja akibat subjek tidak konsisten terhadap usahanya dan sekarang subjek hanya ingin dikamarnya saja setiap harinya, tapi menurut signifikan others dalam waktu-waktu terakhir subjek pernah mengatakan ingin membeli matras untuk yoga lagi.

Untuk mengukur kepuasan subjek terhadap bagian tubuh spesifik dan penampilan secara keseluruhan, subjek menyatakan bahwa tidak ada spesifik nya bagian apa saja yang harus di perbaiki tapi semuanya harus di perbaiki, karena menurut subjek seluruh bentuk tubuh nya adalah besar sehingga seluruh bentuk tubuh nya harus dikecilkan/diperbaiki. Secara keseluruhan subjek mengungkapkan dia tidak puas dengan bentuk tubuhnya sekarang karena tubuh nya terlalu besar sehingga subjek tidak dapat mengikuti trend wanita zaman sekarang yang berpenampilan modis, subjek juga merasa tidak ada yang dapat dia banggakan dari bagian tubuh nya bahkan subjek merasa terganggu karena susahnya mencari baju dan susah nya menaiki tangga ke lantai 3 saat perkuliahan, selain itu subjek tidak bisa menaiki kendaraan karena sulit menahan keseimbangan akibat berat badan hal menyebabkan dirinya harus berjalan kaki setiap hari kekampus dan tidak bisa kemana-mana kecuali ada teman yang mempunyai mobil yang bisa membawanya, subjek juga sering merasa mudah capek dan mengantuk sehingga sangat terganggu.

Untuk mengukur kecemasan dan kewaspadaan subjek terhadap berat badan, seperti melakukan diet dan mebatasi pola makan subjek menyatakan bahwa subjek kesulitan mengontrol porsi makan karena sudah terbiasa sejak SD,SMP,SMA bahkan sampai saat ini makan dengan porsi yang banyak, subjek mengungkapkan bahwa pernah melakukan diet namun kadang-kadang selalu gagal mengontrol pola makan dan akhirnya dietnya gagal bahkan menyebabkan subjek lebih gemuk lagi. Tetapi menurut signifikan others subjek dapat mengontol pola makan nya ketika malam hari, sejak waktu terakhir hingga sekarang subjek mengontrol pola makan nya di malam hari dan menolak makanan yang signifikan others jika dimalam hari, dan untuk siang hari tidak ada kontrol terhadap makanan oleh subjek. Subjek mengungkapkan dalam hal makanan dia memiliki prinsip " buat apa disia-siakan maknan yang enak, maknan enak itu harus di nikmati” sehingga subjek selalu memakan makanan yang dia punya dan sering nyemil. Menurut signifikan others subjek tidak suka maknan-maknan manis seperti coklat,kue dan lain-lain bahkan susu, tetapi subjek selalu memakan cemilan yang berminyak seperti gorengan, keripik-keripik dan lainya tanpa batas tertentu. Subjek menyatakan bahwa sebenarnya ada kepedulian dan keinginan membatasi pola makan yang sehat dengan mengimbangi olahraga karena kewaspadaan nya takut akan penyakitpenyakit seperti jantung,koleterol,darah tinggi akibat obesitas namun subjek kesulitan menghilangkan kebiasaan makan berlebihannya sehingga kesulitan melakukan diet.

Untuk mengukur bagaimana subjek mempersepsikan dan menilai berat badannya, peneliti menanyakan bagaimana tanggapan subjek jika orang lain mengatakan subjek menarik, subjek mengungkapkan bahwa tidak percaya karena kenyataan nya 
dia tidak menarik dan gemuk, bahkan menurut subjek orang lain yang tidak dia kenal memandangnya seperti mengejek. Menurut subjek tubuh ideal wanita itu seperti artis-artis korea, seperti Park Shin Hye dan Ola ramlan.

Adapun faktor-faktor yang mempengaruhi citra tubuh pada subjek yang dapat di gali diwawancara seperti media massa, signifikan others menyatakan subjek menyukai film-film korea sehingga mempengaruhi persepsi bentuk tubuh ideal/kurus wanita itu seperti artis korea. Selanjutnya faktor keluarga subjek mengungkapkan orang tua nya sering melakukan usaha dulu nya seperti menyuruh diet, mebelikan obat pengurus badan dan hasilnya nihil sehingga sekarang orang tua subjek menyerah, tetapi subjek sering di banding-bandingkan dengan kakak nya karena badan obesitasnya yang membuat diri subjek menjadi pemalas dirumah, subjek juga mengungkapkan dia sering di ejek gendut oleh kakak nya bahkan di marahi seperti ketika harus membonceng subjek naik motor karena kesulitan membawa subjek. Dan yang terkahir adalah faktor hubungan interpersonal subjek menyatakan sering merasa minder dengan teman-teman nya dan membandingbandingkan tubuh nya dengan teman-teman nya yang kurus, subjek mngungkapkan ada rasa keinginan seperti teman-teman nya memiliki tubuh kurus dan ideal.

\section{Hasil Observasi}

Berdasarkan hasil observasi yang dilakukan pada tanggal 24 April 2018, pada pukul 09.30-12.30 didapat hasil bahwa untuk dalam orientasi appearance subjek dalam berpenampilan memakai pakaian yang masih kurang cocok untuk tubuhnya karena pakaian yang di pakai subjek terlalu ngepas ditubuhnya sehingga terlihat badan nya yang besar, subjek juga berpenampilan biasa saja tanpa ada usaha memperbaiki penampilannya seperti berakaian trendy layak nya wanita zaman sekarang, ataupun memakai pakaian yang longgar agar menutupi bentuk tubuh nya yang sangat gemuk. Sedangkan, subjek masih terlihat selama observasi seperti memakan cemilan-cemilan kecil dan memakan gorengan yang berminyak, subjek juga makan dengan porsi yang sangat banyak bahkan dari pagi hari awal observasi hingga sore hari setelah wawancara pertama subjek sudah makan 3 kali dengan porsi yang banyak.

Kemudian Observasi selanjutnya tanggal 27 April 2018, pada pukul 10.30-15.30 dilakukan oleh signifikan others yaitu sahabat subjek yang bertempat tinggal satu kost dengan subjek dan satu kelas kuliah dengan subjek, hasil observasi signifikan others subjek menyatakan bahwa untuk dalam orientasi appearance subjek, subjek kuliah dengan memakai pakaian yang masih belum cocok karena agak kekecilan, pakaian yang digunakan subjek juga biasa-biasa saja tanpa model-model tertentu, subjek belum melakukan usaha mengenakan pakaian yang longgar agar menutupi bentuk tubuh besar nya karena subjek kesulitan mencari pakaian yang sesuai dengan bentuk tubuh nya. Sedangkan untuk pada subjek menurut hasil observasi signifikan others subjek tidak ada membatassi dalam hal makanan ataupun cemilan, subjek juga makan dengan porsi yang melebihi orang normal. 
Observasi ke 2 yang menjadi observassi terakhir dilakukan peneliti dilaksanakan pada tanggal 31 April 2018, pada pukul 08.00-12.20. Adapun hasil yang didapatkan adalah dalam orientasi appearance, subjek masih memakai pakaian yang kurang cocok ditubuh nya karena terlalu kecil sehingga terlihat lemak berlebih di bagian-bagian tubuhnya, subjek belum melakukan usaha menutupi bentuk tubuh besarnya dengan memakai pakaia yang longgar, subjek di observasi ke 2 ini juga masih berpenampilan biasa saja. Dan untuk overweight preocupation subjek masih senang memakan cemilan yang dia punya, subjek juga belum ada membatasi porsi makan nya, subjek dari pagi hingga siang hari makan $2 \mathrm{x}$ dengan porsi yang banyak.

\section{Hasil Kuesioner}

Dalam penelitian ini, peneliti menggunakan kuesioner/ angket dengan skala likert yang terdiri dari lima dimensi gambaran tubuh, yaitu evaluasi penampilan, orientasi penampilan, kepuasan terhadap bagian tubuh, kecemasan menjadi gemuk dan pengkategorian ukuran tubuh. Skala ini terdiri dari 4 pilihan jawaban yaitu Sangat Sesuai (SS), Sesuai (S), Tidak Sesuai (TS), dan Sangat Tidak Sesuai (STS). Skala disajikan dalam bentuk pertanyaan favorable (mendukung) dan unfavorable (tidak mendukung). Nilai pilihan bergerak dari 1-4, bobot penilaian untuk pernyataan favorable yaitu $\mathrm{SS}=4, \mathrm{~S}=3$, TS $=2$, $\mathrm{STS}=1$, sedangkan untuk bobot pernyataan unfavorable yaitu $\mathrm{SS}=1, \mathrm{~S}=2, \mathrm{TS}=3, \mathrm{STS}=4$. Adapun angket yang digunakan dalam penelitian ini adalah angket dari penelitian sebelumnya oleh Kinanti Indika, 2010, Universitas Sumatera Utara.

a. Validitas

Untuk mengetahui apakah skala psikologi mampu menghasilkan data yang akurat sesuai dengan tujuan ukurnya, diperlukan suatu pengujian validitas (Azwar, 2004). Angket ini validitas isi tesnya sudah di tentukan melalui pendapat profesional dalam proses telaah soal. Pendapat profesional diperoleh dengan cara berkonsultasi dengan dosen pembimbing.

b. Daya beda aitem

Kemampuan aitem dalam membedakan antara subjek yang memiliki atribut yang diukur dan yang tidak. Selain itu, indeks daya beda aitem merupakan indikator keselarasan atau konsistensi antara fungsi aitem dengan fungsi skala secara keseluruhan yang dikenal dengan konsistensi aitem total. Pengujian daya diskriminasi aitem menghendaki dilakukannya komputasi korelasi antara distribusi skor skala itu sendiri. Komputasi ini akan menghasilkan koefisien korelasi aitem total (r) yang dikenal dengan sebutan parameter daya beda aitem. Kriteria pemilihan aitem berdasarkan korelasi aitem menggunakan batasan $r=$ 0,275 . Pengujian daya diskriminasi aitem pada skala sikap dilakukan dengan mengkorelasikan antara skor tiap aitem dengan skor total, dengan menggunakan teknik korelasi Pearson Product Moment dengan bantuan program SPSS versi 15.

c. Reliabilitas alat ukur

Menurut Azwar (2004), reliabilitas mengacu kepada konsistensi atau keterpercayaan hasil ukur adalah untuk mencari dan mengetahui sejauh mana hasil pengukuran dapat dipercaya. Prosedur pengujian reliabilitas yang 
digunakan dalam angket ini adalah koefisien reliabilitas alpha. Data untuk menghitung koefisien reliabilitas alpha diperoleh melalui penyajian satu bentuk skala yang dikenakan hanya sekali saja pada sekelompok responden (single-trial administratio). Reliabilitas dinyatakan oleh koefisien reliabilitas (r) yang angkanya berada dalam rentang 0 sampai dengan 1 . koefisien reliabilitas semakin mendekati angka 1 menandakan semakin tinggi reliabilitas. Sebaliknya, koefisien yang semakin mendekati angka 0 berarti semakin rendah reliabilitas yang dimiliki. Teknik koefisien alpha untuk menguji reliabilitas alat ukut dihitung dengan bantuan program SPSS versi 15. Hasil uji coba alat ukur di olah melalui tiga kali pengujian agar memperoleh reliabilitas yang memenuhi standar ukur dan indeks daya beda aitem di atas 0,275.

Tabel 1. Hasil Skor (Kuesioner Citra Tubuh)

\begin{tabular}{|l|l|l|l|l|l|l|}
\hline NO & Demensi & Favorable & Unfavorabel & Nilai F & $\begin{array}{l}\text { Nilai } \\
\text { UF }\end{array}$ & $\begin{array}{l}\text { Total } \\
\text { Nilai }\end{array}$ \\
\hline $\mathbf{1 .}$ & $\begin{array}{l}\text { Evaluasi } \\
\text { Penampilan }\end{array}$ & $1,6,10,22$ & $3,8,13,17,27$ & $2,2,2,2$ & $2,2,2,1,1$ & $\mathbf{1 6}$ \\
\hline $\mathbf{2 .}$ & $\begin{array}{l}\text { Orientasi } \\
\text { Penampilan }\end{array}$ & 4,9 & 2,51 & 3,2 & 2,2 & $\mathbf{9}$ \\
\hline $\mathbf{3 .}$ & $\begin{array}{l}\text { Kepuasan Bagian } \\
\text { Tubuh }\end{array}$ & $5,19,23,34$ & $16,28,40$ & $3,3,4,2$ & $3,3,1$ & $\mathbf{1 9}$ \\
\hline $\mathbf{4 .}$ & $\begin{array}{l}\text { Kecemasan } \\
\text { Menjadi Gemuk }\end{array}$ & $30,45,53$ & 12,37 & $3,3,2$ & 2,3 & $\mathbf{1 3}$ \\
\hline $\mathbf{5 .}$ & $\begin{array}{l}\text { Pengkategorisasi } \\
\text { an Ukuran Tubuh }\end{array}$ & $33,43,47,49,55$, & 32,6 & $\begin{array}{l}2,3,2,2,3 \\
, 2\end{array}$ & 3,3 & $\mathbf{2 0}$ \\
\hline & Total & $\mathbf{1 9}$ & $\mathbf{1 4}$ & $\mathbf{4 5}$ & $\mathbf{2 9}$ & $\mathbf{7 7}$ \\
\hline
\end{tabular}

Hasil kuesioner pengukuran citra tubuh yang digunakan dalam penelitian ini memiliki norma sebagai berikut. Gambaran citra tubuh secara keseluruhan dikatakan negatif jika $\mathrm{X}$ $\leq 77$, netral jika $77<X<90$ dan positif jika $X \geq 90$. Adapun norma perdimensi dari 5 dimensi citra tubuh yaitu:

1. Dimensi evaluasi penampilan negatif jika $X \leq 15$, netral jika $15<X<29$, positif jika $X \geq 29$

2. Dimensi orentasi penampilan negatif jika $X \leq 7$, netral jika $7<X<15$, positif jika $X \geq$ 15.

3. Dimensi kepuasan bagian tubuh negatif jika $X \leq 12$, netral jika $12<X<22$, positif jika $X \geq 22$.

4. Dimensi kecemasan menjadi gemuk negatif jika $X \leq 9$, netral jika $9<X<21$, positif jika $X \geq 21$.

5. Dimensi pengkategorisasian ukuran tubuh negatif jika $X \leq 12$, netral jika $12<X<$ 27, positif jika $X \geq 27$ (Kinanti Indika, 2010).

Berdasarkan hasil kuesioner yang didapatkan pada subjek dalam penelitian ini, subjek masih tergolong dalam kategori memiliki citra tubuh yang masih berada pada area netral 77 dan memiliki gambaran yang juga netral pada 5 area dimensi citra tubuh yang ada. 


\section{DISKUSI}

Papalia dan Olds (1995) mengatakan bahwa obesitas atau kegemukan terjadi jika individu mengkonsumsi kalori yang berlebihan dari yang mereka butuhkan. Untuk mengukur lemak tubuh secara langsung sangat sulit dan sebagai pengukur pengganti dipakai body mass index (BMI) atau indeks massa tubuh (IMT) untuk menentukan berta badan yang lebih dan obesitas pada seseorang (Aru W. Sudoyo, 2006). Subjek berinisial MA dan berjenis kelamin perempuan memiliki tinggi badan $170 \mathrm{Cm}$, dengan berat badan $105 \mathrm{Kg}$. Jika di hitung dengan IMT maka di dapatkan hasil 36,3 yang artinya subjek sudah memasuki klasifikasi obesitas II. Adapun faktor-faktor yang mempengaruhi subjek menjadi obesitas seperti kebiasaan pola makan yang berlebihan, sesuai yang di jelaskan subjek dan signifikan others bahwa subjek memiliki porsi makan yang berlebihan/ sangat banyak bahkan tanpa ada batasan makan yang jelas dalam sehari dan hal tersebut sudah menjadi kebiasaan sejak subjek masih SD hingga sekarang. Dari hasil observasi yang dilakukan peneliti dan signifikan others juga menyatakan bahwa subjek memiliki porsi makan yang banyak dan tidak ada batasan dalam makan di kesehariannya, kemudia subjek juga kurang gerak atau olahraga, dalam hasil wawancara bahwa subjek menyatakan bahwa subjek malas untuk berolahraga dan sering malas-malasan. Untuk sekarang subjek sudah menerima dampak obesitas yang yang terjadi pada dirinya seperti gangguan psiko-sosial : Rasa rendah diri, depresif dan menarik diri dari lingkungan. Hal ini dikarenakan anak obesitas seringkali menjadi bahan hinaan teman sepermainan dan teman sekolah. Dapat pula karena ketidakmampuan untuk melaksanaan suatu tugas/kegiatan terutama olahraga akibat adanya hambatan pergerakan oleh kegemukannya. Dari hasil wawancara subjek menyatakan sering minder dan malu karena tubuh nya yang gemuk, subjek juga menungkapkan sering jaddi bahan ejekan orangorang. Pertumbuhan fisik/linier yang lebih cepat dan usia tulang yang lebih lanjut dibanding usia biologisnya. Orang yang memiliki berat badan yang berlebihan seperti subjek sudah pasti memiliki usia tulang yang lebih lanjut dari usia biologisnya. Gangguan pernafasan : Sering terserang infeksi saluran nafas, tidur ngorok, kadangkadang terjadi opnea sewaktu tidur, sering ngantuk siang hari. Bila gangguan sangat berat disebut sebagai sindrom Pickwickian, yaitu adanya hipoventilasi alveolar. Ditemukan dalam hasil wawancara subjek menyatakan sering mengantuk dan menurut signifikan others subjek terkadang mendengkur ketika tidur. Obesitas juga akan berelanjut sampai dewasa, terutama bila obesitas mulai pada pra-pubertal. Obesitas yang terjadi pada subjek dimulai sejak subjek berada di bangku SD hingga sekarang berusia 23 tahun. Hurlock (1999) mengatakan bahwa masa dewasa awal dimulai pada umur 18 tahun sampai umur 40 tahun, saat perubahan-perubahan fisik dan psikologis yang menyertai berkurangnya kemampuan reproduktif. Jika obesitas ini dibiarkan saja, bisa saja kemungkinan akan memberikan dampak kesehatan yang tidak baik kedepannya untuk subjek seperti masalah ortopedi, gangguan endokrin, penyakit degenaratif dan penyakit metabolik (tekanan darah tinggi, jantung, diabetes melitus).

Menurut kamus psikologi (Chaplin, 2005) citra tubuh adalah ide seseorang mengenai penampilannya di hadapan orang (bagi) orang lain. Papalia, Olds, dan Feldman (2001) menyatakan bahwa citra tubuh merupakan gambaran dan evaluasi mengenai penampilan seseorang. Dacey \& Kenny (2001) menyatakan bahwa citra tubuh adalah keyakinan seseorang akan penampilan mereka di hadapan orang lain. Dari hasil tes informal (Anket 
Citra Tubuh) yang di berikan kepada subjek dinyatakan bahwa citra tubuh pada subjek adalah netral, namun netral bukan berarti aman-aman saja nilai netral yag di dapatkan subjek pada tes informal nyaris berada di klasifikasi citra tubuh yang negatif yaitu berada persis di batas antara netral dan negatif (Skor 77), jika dibiarkan saja tanpa ada usaha perbaikan citra tubuh dapat menjadi mediator potensial antara obesitas dan tekanan psikologis (Michael A. Friedman b, Karen Jaffe).

Untuk pengukuran gambaran tubuh dalam penelitian ini menggunakan dimensi-dimensi pada alat ukur yang dikemukakan oleh Cash dkk, (dalam Seawell \& Danorf-Burg, 2005). Cash (2004) mengemukakan adanya lima dimensi citra tubuh, yaitu Appearance Evaluation (Evaluasi penampilan), yaitu mengukur evaluasi dari penampilan dan keseluruhan tubuh, apakah menarik atau tidak menarik serta memuaskan dan tidak memuaskan. Menurut subjek dari hasil wawancara, evaluasi dari penampilan dan keseluruhan bentuk tubuh nya adalah tidak menarik. Menurut nya kelebihan berat badannya membuat dirinya tampak tidak menarik. Appearance Orientation (Orientasi penampilan), yaitu perhatian individu terhadap penampilan dirinya dan usaha yang dilakukan untuk memperbaiki dan meningkatkan penampilan dirinya. Menurut hasil wawancara subjek menyatakan bahwa lebih suka memakai pakaian yang longgar karena menurut nya jika memakai pakaian yang ngepas ditubuhnya akan menampakkan bentuk tubuh gemuknya, tapi subjek masih merasa tidak cocok dengan pakaian yang biasa dia gunakan karena menurutnya pakaian yang biasa digunakannya masih agak kekecilan/ngepas ditubuh dan tidak longgar, sesuai yang dipatkan peneliti dan signifikan others dalam hasil oservassi bahwa subjek masih memakai pakian yang kurang cocok dan tidak longgar ditubuhnya, hal ini senada dengan yg di ungkapkan signifikan others pada saat wawancara bahwa subjek biasa masih memakai pakaian yang ngepas karena subjek kesulitan mencari pakaian yang sesuai dengan bentuk tubuhnya dan subjek juga mengungkapkan halnya demikian, hal ini juga yang menyebabkan subjek tidak dapat mengikuti fashion wanita zaman sekarang agar dapat memperbaiki penampilannya karena menurutnya pakaian yang modis zaman sekarang tidak menyediakan bentuk ukuran besar biasanya hanya sampai seperti ukuran M saja, subjek juga mengungkapkan bahwa subjek tidak dapat mengikuti model hijab zaman sekarang karena subjek mudah kepanasan karena badannya yang besar, subjek juga menyatakan bahwa subjek malas untuk berolahraga agar menguruskan badannya ataupun untuk kesehatannya walaupun sudah sering mendapat dorongan dari teman-temannya, dan menurut signifikan others subjek pernah ingin berolahraga lari pagi setiap hari minggu, bermain hula-hup dengan rutin, pernah ikut yoga,bahkan meminum obat pelangsing dan semuanya gagal begitu saja dan sekarang subjek hanya ingin dikamarnya saja setiap harinya, tapi menurut signifikan others dalam waktu-waktu terakhir subjek pernah mengatakan ingin membeli matras untuk yoga lagi. Body Area Satisfaction (Kepuasan terhadap bagian tubuh), yaitu mengukur kepuasan individu terhadap bagian tubuh secara spesifik, seperti wajah, rambut, tubuh bagian bawah (pantat, paha, pinggul, kaki), tubuh bagian tengah (pinggang, perut), tubuh bagian atas (dada, bahu, lengan), dan penampilan secara keseluruhan.

Menurut hasil wawancara subjek menyatakan bahwa tidak ada spesifik nya bagian apa saja yang harus di perbaiki tapi semuanya bagian tubuhnya harus di perbaiki, karena menurut subjek seluruh bentuk tubuh nya adalah besar sehingga seluruh bentuk tubuh 
nya harus dikecilkan/di perbaiki. Secara keseluruhan subjek mengungkapkan dia tidak puas dengan bentuk tubuhnya sekarang karena tubuh nya terlalu besar sehingga subjek tidak dapat mengikuti trend wanita zaman sekarang yang berpenampilan modis, subjek juga merasa tidak ada yang dapat dia banggakan dari bagian tubuh nya bahkan subjek merasa terganggu karena susahnya mencari baju dan susah nya menaiki tangga ke lantai 3 saat perkuliahan, tidak bisa menaiki kendaraan karena sulit menahan kesseimbangan akibat berat badan menyebabkan dirinya harus berjalan kaki setiap hari kekampus dan tidak bisa kemana-mana kecuali ada temen yang mempunyai mobil yang bisa membawanya, subjek juga sering merasa mudah capek dan mengantuk sehingga sangat terganggu. Overweight Preocupation (Kecemasan menjadi gemuk), yaitu mengukur kecemasan terhadap kegemukan, kewaspadan individu terhadap berat badan, kecenderungan melakukan diet untuk menurunkan berat badan dan membatasi pola makan. Subjek menyatakan bahwa subjek kesulitan megotrol porsi makan karena sudah terbiasa sejak SD,SMP,SMA bahkan hingga kuliah sekarang makan dengan porsi yang banyak, subjek mengungkapkan bahwa pernah melakukan diet namun kadang-kadang selalu gagal mengontrol pola makan dan akhirnya dietnya gagal bahkan menyebabkan subjek lebih gemuk lagi. Hal ini sesuai dengan hasil observasi yang dilakukan peneliti dan signifikan others bahwa subjek selalu makan dengan porsi yang banyak dan tanpa ada batasan. Tetapi menurut signifikan others subjek dapat mengontol pola makan nya ketika malam hari, sejak waktu terakhir hingga sekarang subjek mengontrol pola makan nya dimalam hari dan menolak makanan yang signifikan others jika dimalam hari, dan untuk siang hari tidak ada kontrol terhadap makanan oleh subjek. Subjek mengungkapkan dalam hal makanan dia memiliki prinsip " buat apa disia-siakan maknan yang enak, maknan enak itu harus di nikmati" sehingga subjek selalu memakan makanan yang ada dia punya dan sering nyemil. Menurut signifikan others subjek tidak suka maknan-maknan manis seperti coklat,kue dan lain-lain bahkan susu, tetapi subjek selalu memakan cemilan yang berminyak seperti gorengan, keripik-keripik dan lainya tanpa batas tertentu. Dari hasil observasi juga didapatkan hasil bahwa subjek selalu memakan cemilan-cemilan yang dia punya. Subjek menyatakan bahwa sebenarnya ada kepedulian dan keinginan membatasi pola makan yang sehat dengan mengimbangi olahraga karena kewaspadaan nya takut akan penyakit-penyakit seperti jantung,koleterol,darah tinggi akibat obesitas namun subjek kesulitan menghilangkan kebiasaan nya makan sesukanya sehingga kesulitan melakukan diet. Self-Classified Weight (Pengkategorian ukuran tubuh), yaitu mengukur bagaimana individu mempersepsi dan menilai berat badannya, dari sangat kurus sampai sangat gemuk. Untuk mengukur bagaimana subjek mempresepsikan dan menilai berat badannya, peneliti menanyakan bagaimana tanggapan subjek jika orang lain mengatakan subjek menarik, subjek mengungkapkan bahwa tidak percaya karena kenyataan nya dia tidak menarik dan gemuk, bahkan menurut subjek orang lain yang tidak dia kenal memandangnya seperti mengejek. Menurut subjek tubuh kurus ideal untuk wanita itu seperti artis-artis korea, seperti Park Shin Hye dan Ola ramlan.

Adapun faktor-faktor yang mempengaruhi citra tubuh pada subjek seperti jenis kelamin, Chase (2001) menyatakan bahwa jenis kelamin adalah faktor paling penting dalam perkembangan citra tubuh seseorang. Beberapa penelitian yang sudah dilakukan menyatakan bahwa wanita lebih negatif memandang citra tubuh dibandingkan pria (Cash 
\& Brown, 1989: Davidson \& McCabe, 2005: Demarest \& Allen, 2000: Furnaham \& Greaves, 1994:, Jenelli, 1993: Rozin \& Fallon, 1988 dalam Hubley \& Quinlan, 2005). Usia, Pada tahap perkembangan dewasa awal hal yang umum dilakukan oleh wanita, khususnya mahasiswi dalam menjaga penampilanya adalah dengan pengaturan pola makan. Dijelaskan pada wawancara bahwa ada keinginan subjek menjaga penampilannya dengan membatasi pola makan, dan olahraga agar terlihat menarik, namun masih kesulitan melakukan nya secara konsisten. Media Massa. Tiggemann (dalam Cash \& Pruzinsky, 2002) mengatakan bahwa media yang muncul dimana-mana memberikan gambaran ideal mengenai figur perempuan dan laki-laki yang dapat mempengaruhi gambaran tubuh seseorang. Tiggemann (dalam Cash \&purzinsky, 2002). Diwawancara subjek menyatakan wanita yang ideal adalah seperti artis-artis korea, hal ini disebabkan subjek menyenangi film film korea menurut hasil wawancara signifikan others. Keluarga, Menurut teori social leraning, orang tua merupakan model yang paling penting dalam proses sosialisasi sehingga mempengaruhi gambaran tubuh anak anaknya melalui modeling, feedback dan instruksi. Ikeda and Narworski (dalam Cash dan Purzinsky, 2002) menyatakan bahwa komentar yang dibuat orang tua dan anggota keluarga mempunyai pengaruh yang besar dalam gambaran tubuh anak- anak. Didapatkan dari hasil wawancara subjek mengungkapkan bahwa orang tua nya banyak melakukan intruksi seperti melakukan diet, memberikan obat pengurus badan dan berolahraga kepada subjek, bahkan banyak komentar orang tua subjek terhadap bentuk tubuh subjek seperti di banding-bandingkan dengan kakak nya yang tidak obesitas. Hubungan interpersonal, hubungan interpersonal membuat seseorang cenderung membandingkan diri dengan orang lain dan feedback yang diterima mempengaruhi konsep diri termasuk mempengaruhi bagaimana perasaan terhadap penampilan fisik. Dijelaskan pada hasil wawancara subjek sering membandingkan dirinya dengan teman-teman nya dan menimbulkan keinginan subjek agar memiliki tubuh kurus dan ideal seperti temantemannya hal ini juga yang meyebabkan subjek merasa minder dan kadang-kadang malu dengan teman-temannya.

Hurlock (1999) mengatakan bahwa masa dewasa awal dimulai pada umur 18 tahun sampai umur 40 tahun, saat perubahan-perubahan fisik dan psikologis yang menyertai berkurangnya kemampuan reproduktif. Kebanyakan individu menganggap dirinya telah menyelesaikan perkembangan fisik pada masa remaja mereka, namun faktanya bahwa tubuh terus mengalami perubahan sampai mati, sehingga mahasiswi yang mengalami ketidakpuasaan pada penampilan fisiknya akan menghabiskan banyak waktu dan pikiran untuk memperbaiki penampilan mereka. Namun disini ditemukan bahwa subjek masih belum banyak menghabiskan waktu dan berpikir untuk memperbaiki penampilannya, karena putus asa akibat kegagalan nya melakukan usaha menguruskan badannya selama ini seperti tidak ada efek dari obat pengurus, pola makan yang tidak dapat dijaga konsisten, olahraga yang tidak dapat konsisten. 


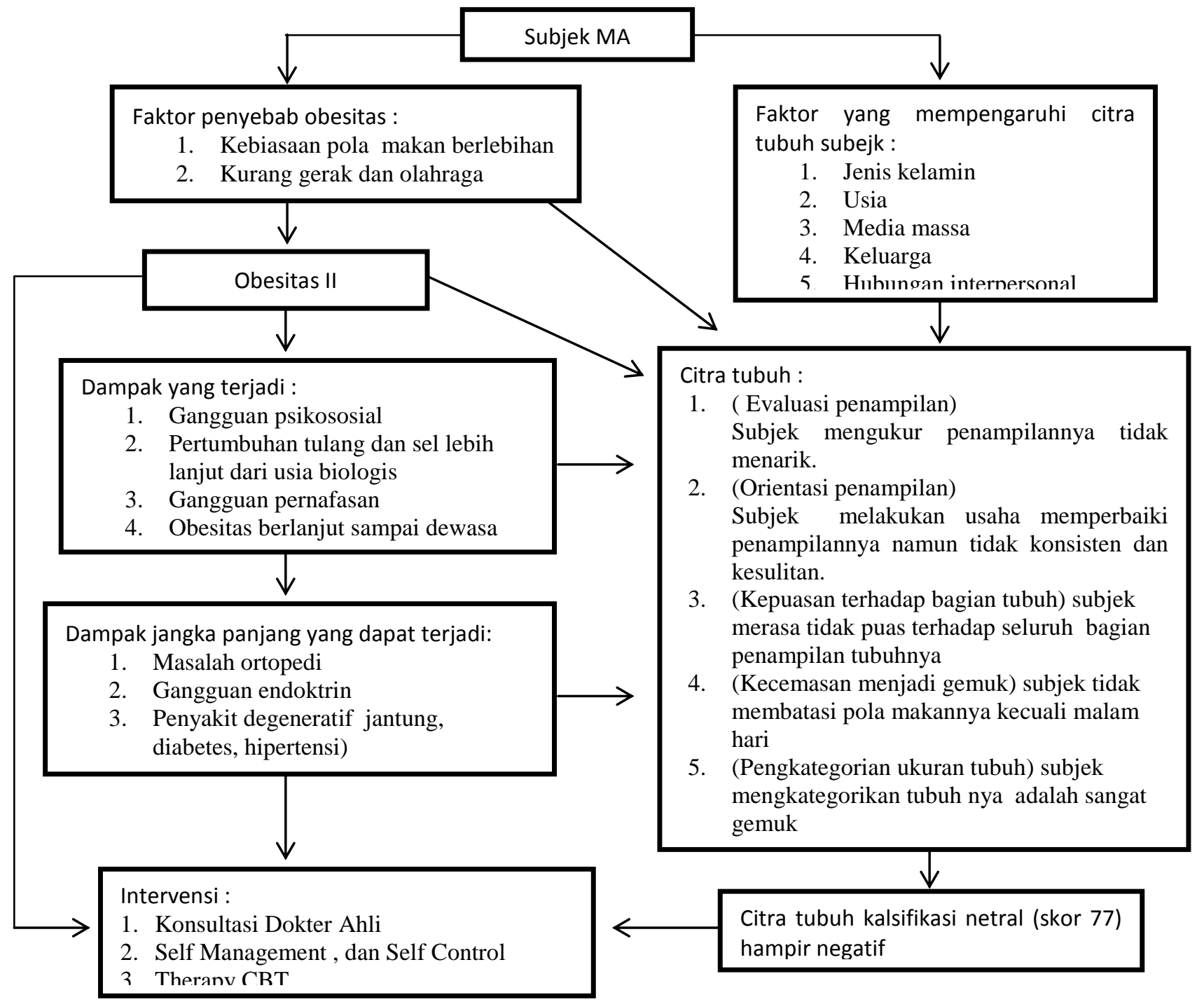

Gambar 1. Psikodinamika/Bagan Masalah

Adapun citra tubuh yang digambarkan subjek secara keseluruhan adalah subjek menganggap orentasi penampilannya secara fisik tidak menarik sama sekali, ia mengalami kesulitan menyesuaikan diri, namun cenderung masih tidak melakukan usaha konsisten mengevaluasi penampilan. Tata laksana utama kegemukan terdiri dari diet dan latihan fisik. Program diet dapat menghasilkan penurunan berat badan dalam jangka pendek, tetapi mempertahankan penurunan berat badan ini seringkali merupakan hal yang sulit dan memerlukan latihan dan diet makanan berenergi rendah sebagai bagian dari gaya hidup yang bersifat permanen. Karena masalah utama pada subjek dalam menurunkan berat badannya adalah tidak konsisten melakukan usaha menguruskan badannya dengan minum obat, olahraga, dan diet.

Maka saran intervensi yang diberikan adalah :

1. Konsultasi Dokter Ahli

Subjek di anjurkan untuk melakukan konsultasi pada dokter ahli karena dengan konsultasi dokter ahli subjek dapat di periksa secara keseluruhan kesehatan 
fisik/biologis nya agar diketahui gangguan fisik/biologis nya yang sudah terjadi dan kemungkinan jangka panjangnya agar diberikan intervensi pengobatan, program diet dan program pencegahan gangguan jangka panjang.

\section{Terapi Psikologis}

a. Self Management dan Self Control

Teknik perubahan perilaku self management merupakan salah satu dari penerapan teori modifikasi perilaku dan merupakan gabungan teori behavioristik dan teori kognitif sosial. Hal ini merupakan hal baru dalam membantu konseli menyelesaikan masalah karena didalam tekhnik ini menekankan pada konseli untuk mengubah tingkah laku yang dianggap merugikan yang sebelumnya menekankan pada bantuan orang lain. Tujuan dari self management pada subjek adalah agar dapat mengembangan perilaku yang lebih adatif . dengan proses pengubahan tingkah laku dengan satu atau lebih strategi melalui pengelolaan tingkah laku internal dan eksternal individu, agar dapat meberi penerimaan individu terhadap program perubahan perilaku menjadi syarat yang mendasar untuk menumbuhkan motivasi individu untuk melakukan usaha menguruskan badannya, disini subjek juga berpartisipasi untuk menjadi agen perubahan perilakunya, juga agar subjek dapat menggeneralisasi dan tetap mempertahankan hasil akhir usahanya menurunkan berat badan dengan jalan mendorong individu untuk menerima tanggung jawab menjalankan strategi mengurud-skan badannya dalam kehidupan sehari-hari, subjek juga di ajarkan menggunakan ketrampilan menangani masalah makan nya dan rasa malasnya berolahraga.

Menurut kamus psikologi (Chaplin, 2002), definisi kontrol diri atau self control adalah kemampuan individu untuk mengarahkan tingkah lakunya sendiri dan kemampuan untuk menekan atau menghambat dorongan yang ada. Goldfried dan Merbaum, mendefinisikan kontrol diri sebagai suatu kemampuan untuk menyusun, membimbing, mengatur dan mengarahkan bentuk perilaku yang dapat membawa individu kearah konsekuensi positif.

Kontrol diri merupakan satu potensi yang dapat dikembangkan dan digunakan individu selama proses-proses dalam kehidupan, termasuk dalam menghadapi kondisi yang terdapat dilingkungan yang berada disekitarnya, para ahli berpendapat bahwa kontrol diri dapat digunakan sebagai suatu intervensi yang bersifat preventif selain dapat mereduksi efek-efek psikologis yang negative dari stressor-stresor lingkungan. Disamping itu kontrol diri memiliki makna sebagai suatu kecakapan individu dalam kepekaan membaca situasi diri dan lingkungannya serta kemampuan untuk mengontrol dan mengelola faktor-faktor perilaku sesuai dengan situasi dan kondisi untuk menampilkan diri dalam melakukan sosialisasi sehingga tujuan dari kontrol diri pada subjek agar subjek dapat lebih dapat mengelola dan mengontrol dirinya terhadap menampilkan dirinya dalam sosialisasi hidupnya agar dapat mereduksi efek-efek negatif dari stressor lingkungannya.

b. Dengan menggunakan CBT ( Cognitif Behavioral Therapy). Terapi kognitifperilaku (CBT) merupakan terapi yang mendasarkan pada teori kognitif 
perilaku yang menekankan pikiran, perasaan dan perilaku, Menurut teori ini psikopatologi terjadi bila terdapat ketidak sesuaian antara tuntutan-tuntutan lingkungan dengan kapasitas adaptif individu. Teori ini sangat efektif karena penderita telah memiliki kesadaran bahwa mereka memiliki berat badan yang berlebih, pola makan yang tidak normal. Namun mereka tidak berdaya untuk mengendalikan dorongan makan pada saat perut terasa lapar sehingga diperlukan penyadaran pikiran dan perasaan agar subjek mampu mengenali dan kemudian mengevaluasi atau rnengubah cara berfikir, keyakinan dan perasaannya (mengenali diri sendiri dan lingkungan) yang salah, dapat mengubah perilaku maladaptive dengan cara mempelajari ketrampilan pengendalian diri dan staregi pemecahan masalah yang efektif. Misalnya subjek diminta untuk melakukan latihan-latihan menantang pikiran yang negatif seperti membandingkan gambar-gambar wanita atau pria yang mempunyai tubuh gemuk dan yang mempunyai tubuh ramping dengan tujuan mernbangkitkán persepsi yang berhubungan dengan body image nya. Hasil kajian yang dilakukan oleh American Dietetic Association (ADA) antara Juli 2007dan Maret 2008 menunjukkan bahwa, penerapan teori perilaku dan teori perilaku berbasis kognitif (CBT) sangat efektif untuk memfasilitasi klien dalam modifikasi diet, target penurunan berat badan (Iis Rosita, dkk. (2011).

\section{SIMPULAN DAN IMPLIKASI}

Berdasarkan hasil uraian tersebut, dapat disimpulkan bahwa citra diri subjek MA yang mengalami obesitas II adalah netral dengan skor 77 namun skor ini bukan berarti amanaman saja tetapi juga perlu di perbaiki bahkan hampir mendekati negatif. Subjek menganggap orentasi penampilannya secara fisik tidak menarik sama sekali, ia mengalami kesulitan menyesuaikan diri, namun cenderung masih tidak melakukan usaha konsisten mengevaluasi penampilan. Tata laksana utama kegemukan terdiri dari diet dan latihan fisik. Program diet dapat menghasilkan penurunan berat badan dalam jangka pendek, tetapi mempertahankan penurunan berat badan ini seringkali merupakan hal yang sulit dan memerlukan latihan dan diet makanan berenergi rendah sebagai bagian dari gaya hidup yang bersifat permanen. Karena masalah utama pada subjek dalam menurunkan berat badannya adalah tidak konsisten melakukan usaha menguruskan badannya dengan minum obat, olahraga, dan diet.

Adapun saran-saran yang diberikan untuk subjek, di anjurkan untuk melakukan konsultasi pada dokter ahli karena dengan konsultasi dokter ahli subjek dapat di periksa secara keseluruhan kesehatan fisik/biologis nya agar diketahui gangguan fisik/biologis nya yang sudah terjadi dan kemungkinan jangka panjangnya agar diberikan intervensi pengobatan, program diet dan program pencegahan gangguan jangka panjang. Subjek juga di anjurkan agar melakukan psikoterapi CBT dan Self Management, Self Control dengan Psikolog guna membantu masalahnya dalam melakukan usaha menguruskan badan dengan konsisten.

Untuk masyarakat luas, dapat sebagai referensi bagi wanita dewasa awal/mahasiswi yang mengalami obesitas agar mendapatkan gambaran mengenai citra tubuh., juga sebagai 
referensi bagi keluarga, agar dapat memberikan informasi tentang citra tubuh. Hal ini bertujuan orang yang mengalami obesitas dapat menerima keadaan tubuh atau fisiknya secara positif atau baik.

Untuk peneliti selanjutnya, diharapkan dapat menyempurnakan hasil temuan ini dengan membandingkan pada beberapa subjek serupa yang lebih banyak dan mungkin dapat menambah teori-teori yang ada agara lebih banyak referensi yang digunakan, sehingga mudah dalam melakukan analisis dan pembahasan.

\section{REFRENSI}

Alwisol. (2009). Psikologi Kepribadian Edisi Revisi. Malang: UMM Press.

Basow, A. Susan. (1992). Garden: Sereoyupes and Roles (3rd). California: Books Publishing Company

Bigner, J.J. (1994). Parent Child Relations: an Introduction to Parenting (4th ed).

Chaplin, C.P. (2005). Kamus Lengkap Psikologi, Terj. Kartini Kartono, Jakarta

Chas, F. Thomas. (1999). Body image, development, deviance, and change. New York: The Guilford Press.

Chas, F. Thomas. (2004). Body image: past, present, and future. Journal of Psychology, Old Dominion University : Norfolk, Virginia, VA 23529, USA

Dacey, J and Kenny, M. (1997). Adolescent Development (2nd). USA: Brown and Benchmark Publishers

Dacey, J., \& Kenny, Maureen. (2001). Adolescent development (2nd ed). USA: Brown \& Benchmark Publisher.

Dewi, Amanah. (2004). Perbedaan Kepercayaan Diri antara Remaja Pria dan Wanita yang Mengalami Obesitas pada Siswa/i SMAN di kota Rantauparapat. Universitas Medan Area

Friedmann, Kellie.E., Simona K. Reichmann (2002). Body Image Partially Mediates the Relationship between Obesity and Psychological Distress. Vol.10 :33-41.

Harisson, Kristen (2003). Television Viewer's Ideal Body Proportions: The Curvaceously Thin women Sex Roles: A Journal of Research. Plenum Publishing Coorporation: Illinois.

Hurlock, B. Elizabeth. (1999). Psikologi Perkembangan: Suatu Pendekatan Sepanjang Rentang Kehidupan. Jakarta: Penerbit Erlangga.

Hurlock, E. (1980). Psikologi Perkembangan: Suatu Rentang Kehidupan. Jakarta: Erlangga. 
Iis Rosita, dkk. (2011). Konseling Gizi Transtheoritical Model dalam Mengubah Perilaku Makan dan Aktivitas Fisik pada Remaja Overweight dan Obesitas. Jurnal Fakultas Kedokteran, Universitas Padjajaran: Bandung

Indika, Kinanti. (2010). Gambaran Citra Tubuh Pada Remaja Yang Obesitas. Fakultas Psikologi: Universitas Sumatera Utara.

Indonesian Nutrion Network, 2005

Leliana. Yuliana. (2004). Konsep Diri Remaja Putri yang Mengalami Obesitas.Artikel Fakultas Psikologi, Universitas Gunadharma: Depok

Mengenali Obesitas (2007). Online http//www.wikipedia.com

Michael A. Friedman b, Karen Jaffe (2007). Understanding the relationship between obesity and positive and negative affect: The role of psychosocial mechanisms. Department of Sociology and Center for Demography of Health and Aging, University of Wisconsin, United States.

Monks, F.J., Knoers, A.M.P., \& Haditono, S.R. (2001). Psikologi perkembangan: pengantar dalam Berbagai Bagiannya. Yogyakarta: Gadjah Mada University Press

Nasar SS. (1995). Obesitas pada anak aspek klinis dan pencegahannya. Dalam: Samsudin, Nasar SS, Sjarif Dr, Penyunting Naskah Lengkap PKB-IKA XXXV. Masalah Gizi Ganda dan Tumbuh Kembang Anak. Jakata: Bina Rupa Aksara. H. 68-81.

Papalia, D. E., Olds, S. W., \& Feldman, R.D. (2008). Human Development (Psikologi Perkembangan Edisi ke 9). Jakarta: Kencana

Papalia, E. Diane., Olds, W.S., Feldman D.R. (2001). Human development (8th ed). New York: McGraw-Hill,Inc.

Ramayulis, Rita. (2007). 17 Alternatif untuk Langsing. Jakarta: Gramedia

Rupang, Indra.dkk (2014). Hubungan Tingkat Kepercayaan Diri Dengan Obesitas Pada Siswa SMA Rex Mundi Manado. Jurnal Bagian Psikologi Fakultas Kedokteran Universitas Sam Ratulangi: Manado.

Santrock, J. W. (2008). Life span development (Perkembangan sepanjang hidup). Jilid 1. Jakarta: Erlangga.Sarafio, Edward P, (1998). Health Psychology : Biopsychosocial Interaction (3rd edition). Ney York: John Wiley and Sons. Inc

Saryono. 2011. Metodologi Penelitian Kualitatif dalam Bidang Kesehatan. Yogyakarta: Nuha Medika.

Schlundt, D.J and johnson, A. (1990). Eating Disorder: Assessment and Teratment. Boston: Allyn and Bacon

Sugiyono. (2010). Memahami Penelitian Kualitatif. Bandung: Alfabeta 


\title{
VALIDITAS KONSTRUK ALAT UKUR KESALEHAN SOSIAL
}

\author{
Istiqomah \\ Fakultas Psikologi Universitas Muhammadiyah Malang \\ istiqomah@umm.ac.id
}

\begin{abstract}
Abstrak. Alat ukur kesalehan sosial adalah alat ukur yang terdiri dari 41 item dengan tujuh dimensi yang diukur yaitu (a) solidaritas sosial (al-takaful al-ijtima'i), (b) toleransi (al-tasamuh), (c) mutualitas/kerjasama (al-ta'awun), (d) tengah-tengah (al-I'tidal), dan (e) stabilitas (al-tsabat) (f) menolong dan (g) kejujuran. Tujuan dari pengembangan alat ukur ini adalah untuk mengembangkan alat ukur kesalehan sosial, menguji validitas dan reliabilitas alat ukur kesalehan sosial dan mendeskripsikan tingkat kesalehan sosial karyawan. Subjek penelitian adalah karyawan pada beberapa perusahaan dan karyawan pada instansi pemerintah. Hasil analisis data menunjukkan dari 41 item yang dikembangkan terdapat 14 item yang gugur dan 27 item yang valid dengan reliabilitas sebesar 0,797 .
\end{abstract}

Kata Kunci: Validitas Konstruk, Alat Ukur Kesalehan Sosial

\begin{abstract}
The measure of social piety is a instrument consisting of 41 items with seven dimensions measured there are (a) social solidarity (al-takaful al-ijtima'i), $(b)$ tolerance (al-tasamuh), (c) mutuality / cooperation (al-ta'awun), (d) midst (al-I'tidal), and (e) stability (al-tsabat) $(f)$ help and $(g)$ honesty. The purpose of the development of this measuring instrument is to develop a instrumen of social piety, test the validity and reliability of measuring instruments of social piety and describe the level of employee social piety. The research subjects were employees of several companies and employees of government agencies. The results of data analysis showed that from 41 items developed there were 14 items that were dropped and 27 items were valid with reliability of 0.797 .
\end{abstract}

Keywords: Construction Validity, Social Piety Measurement Tool 
Kesalehan merupakan penghayatan dan pengamalan ajaran agama secara sempurna. Seorang muslim mengamalkan ajaran islam berarti mengamalkan ajaran islam dan berada pada proses pencapaian kesalehan. Pengamalan yang terus menerus terhadap ajaran islam menjadi awal tertanamnya kesalehan dalam jiwa setiap muslim. Perintah menjalankan agama tujuan utamanya adalah mencetak hamba Allah yang sholeh yang tidak hanya berakibat positif pada dirinya tetapi juga pada lingkungannya.

Islam memiliki nilai yang secara universal mengajarkan umatnya untuk senantiasa berubah dari kejelekan menuju kebaikan (transformatif) yakni Allah tidak merubah keadaan suatu kaum sehingga mereka merubah keadaan yang ada pada diri mereka sendiri. Ajaran Islam inilah hadir untuk selalu mengentas manusia dari berperadaban rendah menuju manusia yang berperadaban tinggi. Ajaran Islam inilah yang juga menjadi kekuatan pendidikan Islam untuk selaras dengan misi utama Nabi yang diutus oleh Allah untuk memperbaiki karakter dan perilaku ummat. Perbaikan karakter dan perilaku merupakan bagian sangat penting untuk membangun kualitas hidup dan peradaban manusia, dengan transformasi kesalehan individu menuju kesalehan sosial diharapkan individu mampu menghadapi gencarnya arus globalisasi.

Kesalehan sosial adalah sebagai kesalehan yang menunjukkan pada prilaku orang yang peduli dengan dengan nilai-nilai Islami, yang bersifat sosial. Proses terbentuknya kesalehan sosial dapat di-lacak dari interseksi antara aspek material dan aspek spiritual dalam beribadah. Spiritual dipahami sebagai usaha untuk mendekatkan diri kepada Sang Khalik, sementara material dapat dipandang sebagai alat penujang spiritual tersebut. Menjadi orang saleh memang menjadi tujuan utama kesalehan sosial ini, namun yang lebih penting lagi adalah pengakuan dan afirmasi dari masyarakat terhadap kesalehan sosial yang dkonstruksikan tersebut.

Kesalehan menjadi motivator pembentukan sifat terpuji dalam kehidupan nyata. Hal ini dikarenakan kesalehan menumbuhkan kesadaran dan keyakinan bahwa ajaran islam hanya mengajarkan sesuatu yang baik dan terpuji. Kesadaran ini pada gilirannya mendorong pemiliknya untuk mengajak orang lain menjadi saleh. Dengan demikian orang yang saleh memiliki kepekaan yang tinggi terhadap lingkungan sekitarnya (Helmi, 2014).

Dalam Al Qur an Allah menjelaskan dua kategori indikator kesalehan manusia yaitu kesalehan individual dan kesalehan sosial. Kesalehan individual adalah kemampuan bersyukur kepada Allah atas nikmat yang diberikan kepadanya atau orang-orang yang dicintainya dan keteguhannya dalam berbuat amal sholeh (Habblum minnallah). Kedua adalah kesalehan sosial, indikatornya adalah mempunyai kepekaan sosial yang tinggi yang berawal dari keinginannya untuk memberdayakan orang orang disekelilingnya (hablum-minnas).

Sebagai perilaku keagamaan, konsepsi Islam tersebut lebih dapat menjelaskan tentang kesalihan sosial sebagai bagian dari perbuatan manusia. Hal ini didasari beberapa pemikiran yaitu, pertama, perbuatan manusia banyak didasari atas kehendak dirinya dan tidak bisa semata-mata didasari atas determinan sebagaimana dalam psikoanalisa, atau 
sebagai diri. yang tidak memiliki kesadaran laksana kapas yang diterbangkan angin seperti dalam behaviorisme, atau peniruan sebagaimana dikenal dalam teori modelling. Kedua, salah satu karakteristik manusia adalah adanya kesadaran untuk selalu introspeksi, berdialog dengan dirinya sendiri, dan selalu berhubungan dengan lingkungan alam fisik. Manusia selalu berinteraksi dengan diri sendiri, lingkungan sekitar, dan alam keruhanian. Semenjak awal telah menjelaskan bahwa manusia adalah satu-satunya makhluk yang dalam unsur penciptaannya terdapat ruh Ilahi. Kesalihan sosial adalah bagian dari interaksi seseorang dengan pengalaman keruhaniannya. Ketiga, sebagai makhluk berkesadaran, perilaku manusia didasari atas pilihan dan putusan rasional. Maka perilaku manusia seharusnya bisa terlepas dari pengaruh lingkungan sekitarnya. Seorang yang salih akan tetap salih meski lingkungan sekitarnya banyak kriminalitas, korupsi, dan kejahatan lainnya.

Kesalehan sosial merupakan orientasi religious individu dimana tidak hanya berhubungan dengan Allah tetapi juga merupakan orientasi religious individu dalam berinteraksi dengan sesama. Moltafet, Mazidi, \& Sadati, (2010) dalam penelitiannya menyatakan bahwa terdapat hubungan yang signifikan antara orientasi religious dengan dengan dimensi kepribadian.

Teori dalam psikologi yang bisa dekat dengan konsep kesalehan sosial adalah konsep hasrat untuk hidup bermakna (the will to meaning) yang dikemukakan Viktor Frankl. Konsep "hidup bermakna" adalah motivasi utama setiap manusia, konsep ini deperkuat dengan konsep "hati nurani" Frankl, Menurut Frankl hati nurani adalah semacam spiritualitas alam bawah sadar, yang sangat berbeda dengan insting-insting alam bawah sadar seperti yang dikemukakan Frued. Teori lain yang memiliki aspek-aspek yang memiliki kesamaan dengan kesalehan sosial adalah prososial. Prososial adalah peaku yang memiliki konsekuensi positif terhadap orang lain (Baron R.A.\& Byrne, 2004). Perilaku prososial meliputi menolong, berbagi rasa, kerja sama menyumbang dan memperhatikan kesejahteraan orang lain.

Kesalihan sosial adalah bentuk perilaku keagamaan seseorang yang lahir dari sikap keagamaan, sementara sikap keagamaan lahir dari pemahaman seseorang atas nilai-nilai yang difahami (kognitif), dirasakan (afektif), dan dilakukan (konatif). Penelitian yang dilakukan oleh (Aghababaei, 2014) yang meneliti tentang korelasi antara religiusitas, well being dan personality menunjukkan bahwa religiusitas berkorelasi positif dengan keadilan. Sedangkan salah satu aspek dalam kesalehan sosial dan prososial adalah keadilan.

Penelitian yang dilakukan oleh (Miyatake \& Higuchi, 2017) menunjukkan bahwa orientasi keagamaan dapat meningkatkan perilaku prososial individu dimana perilaku tersebut merupakan dasar dalam menumbuhkan perilaku membantu, berbagi antar sesama. Konsep yang ditanamkan adalah bahwa dalam kegiatan mereka sehari hari selalu diawasi oleh tuhan.

Berdasarkan pemaparan diatas maka dibutuhkan alat ukur yang dapat mengungkap tentang Kesalehan Sosial. Alasan utamanya adalah belum ada alat ukur yang mengungkap tentang kesalehan sosial. Studi ini merupakan studi awal dalam pengembangan alat ukur dan pengujian validitas konstruk alat ukur kesalehan sosial. 
Tujuan Penelitian dari penelitian ini adalah:

1. Mengembangkan alat ukur kesalehan sosial

2. Menguji validitas dan reliabilitas alat ukur kesalehan sosial

3. Mendeskripsikan tingkat kesalehan sosial pada masyarakat beragama di Indonesia Manfaat Penelitian:

1. Memberikan khasanah baru dalam bidang psikologi Agama tentang pengembangan alat ukur kesalehan sosial.

2. Dari pengembangan dan pengujian validitas dan reliabilitas alat ukur kesalehan sosial akan diperoleh alat ukur psikologi yang memenuhi prinsip-prinsip pengukuran (psikometri).

Kesalehan sosial dipahami sebagai kesalehan yang menunjukkan pada prilaku orang yang peduli dengan dengan nilai-nilai Islami, yang bersifat sosial. Maka yang terpenting sekarang adalah menjadikan satu ibadah tidak hanya bernilai kesalehan individu tapi sekaligus bernilai kesalehan sosial. Sehingga ibadah itu tidak terdikhotami antara individu dan social (Riadi H, 2014).

Kesalehan Sosial menunjuk pada perilaku orang-orang yang sangat peduli dengan nilainilai islami, yang bersifat sosial. Bersikap santun pada orang lain, suka menolong, sangat concern terhadap masalah-masalah ummat, memperhatikan dan menghargai hak sesama; mampu berpikir berdasarkan perspektif orang lain, mampu berempati, artinya mampu merasakan apa yang dirasakan orang lain, dan seterusnya. Kesalehan sosial dengan demikian adalah suatu bentuk kesalehan yang tak cuma ditandai oleh rukuk dan sujud, puasa, haji melainkan juga ditandai oleh seberapa besar seseorang memiliki kepekaan sosial dan berbuat kebaikan untuk orang-orang di sekitarnya. Sehingga orang merasa nyaman, damai, dan tentram berinteraksi dan bekerjasama dan bergaul dengannya.

Kesalehan sosial adalah perilaku orang-orang yang sangat peduli dengan nilai-nilai Islami, yang bersifat sosial. Suka memikirkan dan santun kepada orang lain, suka menolong, meskipun orang-orang ini tidak setekun kelompok yang sangat taat dalam melakukan ibadah seperti sembayang dan sebagainya tetapi lebih mementingkan hablun minan naas (Bisri $\mathrm{H}, 2018$ ). Boleh jadi hal itu memang bermula dari fenomena kehidupan beragama kaum Muslim itu sendiri, dimana memang sering kita jumpai sekelompok orang yang tekun beribadat, bahkan berkali-kali haji misalnya, namun kelihatan sangat bebal terhadap kepentingan masyarakat umum, tak tergerak melihat saudara-saudaranya yang lemah tertindas, misalnya. Seolah-olah Islam hanya mengajarkan orang untuk melakukan hal-hal yang dianggapnya menjadi hak Allah belaka. Sebaliknya juga, sering dijumpai orang-orang Islam yang sangat concern terhadap masalah-masalah ummat, sangat memperhatikan hak sesamanya, kelihatan begitu mengabaikan ibadat pribadinya.

Definisi Konseptual, kesalehan sosial adalah sikap seseorang yang memiliki unsur kebaikan (salih) atau manfaat dalam kerangka hidup bermasyarakat. Sikap kesalehan sosial tersebut meliputi: (a) solidaritas sosial (al-takaful al-ijtima'i), (b) toleransi (al- 
tasamuh), (c) mutualitas/kerjasama (al-ta'awun), (d) tengah-tengah (al-I'tidal), dan (e) stabilitas (al-tsabat).

Kesalihan sosial adalah bentuk perilaku keagamaan seseorang yang lahir dari sikap keagamaan, sementara sikap keagamaan lahir dari pemahaman seseorang atas nilai-nilai yang difahami (kognitif), dirasakan (afektif), dan dilakukan (konatif). Salah satu teori yang mungkin bisa menggambarkan tentang kesalehan sosial adalah adanya teori tentang prososial yaitu perilaku prososial merupakan tindakan altruisme yang tidak mementingkan diri sendiri atau tanpa pamrih sampai tundakan menolong yang sepenuhnya dimotivasi oleh diri sendiri Rushton ( dalam Sears, dkk. 2005). Perilaku prososial didefinisikan sebagai sebagai perilaku yang memiliki konsekuensi positif pada orang lain. Bentuk yang paling jelas dari prososial adalah perilaku menolong. Lebih spesifik lagi, Eisenberg dan Mussen (dalam Dayakisni,2009) memberi pengertian perilaku prososial mencakup pada tindakan-tindakan: sharing (membagi), cooperative (kerjasama), donating menyumbang, helping (menolong), honesty (kejujuran) generosity (kedermawanan) serta mempertimbangkan hak dan kesejahteraan orang lain.

Kajian ini menggunakan teori sebagaimana dalam teori prososial karena adanya kesesuaian dengan pandangan para pemikir Islam bahwa manusia adalah makhluk yang memiliki kesadaran sebagai 'khalifah' Tuhan. Sehingga kesadaran inilah yang dianggap menentukan perbuatan seseorang yang berulang-ulang terhadap objek social bukan karena adanya pengaruh sosial Pertama, kesalehan sosial adalah sikap seseorang yang memiliki unsur kebaikan (salih) atau manfaat dalam kerangka hidup bermasyarakat. Sikap kesalehan sosial bisa meliputi: (a) solidaritas sosial (al-takaful al-ijtima'i), (b) toleransi (al-tasamuh), (c) mutualitas/kerjasama (al-ta'awun), (d) tengah-tengah (alI'tidal), dan (e) stabilitas (al-tsabat). Kedua, kesalehan sosial dalam perspektif tokohtokoh muslim adalah berangkat dari kesadaran manusia sebagai makhluk Tuhan yang bertanggung jawab atas kehidupan di bumi dan sekaligus menjalankan tugas sebagai 'wakil Tuhan' (khalifah) di bumi, Ketiga, dalam psikologi kognitif dikenal adanya bentuk kesadaran dalam diri individu yaitu teori tentang konsep diri yang berasal dari dimensi pengetahuan, dimensi pengharapan, dan dimensi penilaian. Konsep diri inilah yang menentukan perbuatan seseorang, yang berulang-ulang terhadap objek sosial. Keempat, kesalehan sosial sebagai attitude atau sikap mempunyai tiga aspek yaitu kognitif, afektif, dan konatif. Sikap bisa berubah dalam hal intensitasnya, namun biasanya konsisten sepanjang waktu dalam situasi yang sama, dan komposisinya hampir selalu kompleks. Kelima, kesalehan sosial merupakan salah satu bagian dari capaian seseorang dalam memberikan "pemaknaan" terhadap hidupnya di bumi (will to meaning).

Penelitian Kesalehan sosial secara khusus juga pernah dilakukan oleh Mohammad Sobary dengan judul Kesalehan Sosial (Influence of Islamic piety on the rural economic behavior in Suralaya, Jawa Barat Province. 2007, Yogyakarta: LKiS) Penelitian ini merupakan tesis Sobary di Universitas Monash, Australia. Sobary dalam tesisnya ini, mengungkap peranan Agama dalam mewujudkan hubungan yang positif antara "Kesalehan" dan "Tingkah Laku Ekonomi" di Desa Suralaya. Oleh karena itu, penelitian etnografis yang dilakukannya berupaya untuk menemukan beberapa konsep 
kunci yang sangat penting dalam menemukan peranan agama dalam masyarakat Suralaya.

Kesalehan sosial telah diteliti sebelumnya oleh (Zuhri, 2014) mengenai Pendidikan Transformasi Kesalehan Individu Menuju Kesalehan Sosial Hasil penelitiannya adalah pertama; transformasi kesalehan individu menuju kesalehan sosial dapat tercapai dengan tiga proses yakni individu memahami fungsi agama Islam secara transformatif, individu memahami peran agama Islam secara transformatif dan individu mampu mentransformasikan Islam. Kedua; dampak globalisasi terhadap perkembangan pendidikan Islam yakni globalisasi sangat mempengaruhi masyarakat, dimana sebarannya sangat luas dari orang dewasa sampai anak-anak. Akibatnya paedagogi pesrta didik tidak luput dari arusnya sehingga karakter, potensi dan akhlak (tingkahlaku) ikut terpengaruh dengan tren globalisasi. Ketiga, cara pendidikan Islam mentransformasikan kesalehan individu menuju kesalehan sosial di era global adalah pentransformasian dilakuakan secara teoritis dan praktis.

Penelitian lain dilakukan oleh Greedy M. A (2003) meneliti tentang kesalehan sosial dan pragmatisme yang merupakan trens politik islam di Indonesia. Ada kecenderungan politik Islam di Indonesia dilakukan oleh pemerintah dan mereka kurang menerapkan nilai kesalehan sosial.

Penelitian yang dilakukan oleh Riadi H (2014) mengenai kesalehan sosial sebagai parameter kesalehan keberislaman menyimpulkan bahwa Islam mengutamakan kehidupan sosial, maka kesalehan sosial sebagai parameter kesalehan keberagamaan perlu dibangun. Pada sisi lain, konsep tauhid serta ibadah tidak akan bermakna bila tidak dipahami dalam perspektif sosial. Karenanya merupakan suatu keniscayaan mengukur kesalehan seseorang dalam perspektif sosial. Maka upaya yang dilakukan adalah mengembalikan semua bentuk ajaran kedalam praktek yang bernilai sosial dan merupakan kesadaran kesalehan sosial.

Aspek alat ukur Kesalehan Sosial antara lain (Mahfud S, 1994) :

a) Solidaritas sosial adalah kesediaan untuk memberi dan peduli kepada orang lain tanpa mengharapkan imbalan.

b) Kerja sama atau mutualitas adalah melakukan pekerjaan atau aktivitas secara bersama sama berdasarkan kesepakatan untuk mencapai tujuan bersama pula.

c) Toleransi ialah mampu menghargai perbedaan nilai-nilai kehidupan, tidak memaksakan nilai pada orang lain serta tidak menghina atau merusak nilai yang berbeda.

d) Adil dan seimbang merupakan perilaku yang mampu bertindak sesuai dengan proporsi, tersedianya kesempatan yang sama dalam bekerja dan beraktualisasi.

e) Menjaga ketertiban umum yaitu suatu tindakan yang berhubungan dengan orang lain tanpa mengganggu, merugikan dan melanggar kesejahteraan orang lain.

Eisenberg dan Mussen (dalam Dayakisni, 2009) memberi pengertian prososial sebagai tindakan yang mencakup:

a. Sharing (membagi) yaitu memberikan kesempatan kepada orang lain untuk dapat merasakan sesuatu yang dimilikinya termasuk keahlian dan pengetahuan 
b. Cooperative (kerjasama) yaitu melakukan kegiatan bersama dengan orang lain untuk mencapai tujuan bersama termasuk mempertimbangkan dan menghargai pendapat orang lain dalam berdiskusi

c. Donating (menyumbang) adalah perbuatan yang memberikan secara materiil kepada seseorang atau kelompok untuk kepentingan umum yang berdasarkan pada permintaan, kejadian dan kegiatan.

d. Helping (menolong) adalah membantu orang lain secara fisik untuk mengurangi beban yang sedang dilakukan

e. Honesty (kejujuran) adalah tindakan dan ucapan yang sesuai dengan keadaan yang sebenarnya

f. Generosity (kedermawanan) ialah memberikan sesuatu kepada orang laian atas dasar kesadaran diri

g. Mempertimbangkan hak dan kesejahteraan orang lain ialah suatu tindakan untuk melakukan suatu hal untuk kepentingan pribadi yang berhubungan dengan orang lain tanpa mengganggu dan melanggar kesejahteraan orang lain.

Aspek aspek kesalehan sosial yang sama dengan aspek teori psikologi prososial adalah solidaritas dengan donating, helping dan kooperatif, sharing dengan adil, dalam kedua konstruk tersebut memiliki aspek sama yaitu kerja sama, serta menjaga ketertipan umum dengan mempertimbangkan hak dan kesejahteraan orang lain.

Validitas adalah ketepatan tes dalam mengukur sesuatu yang harus diukur. Gronlund (1982) secara umum mengartikan validitas sebagai sejauh mana hasil tes dapat dipakai untuk tujuan yang dimaksudkan. Dengan perkataan lain validitas adalah kesesuaian tafsiran mengenai hasil tes.

Azwar (2013) mengemukakan suatu alat ukur dikatakan mempunyai validitas yang tinggi apabila tes tesebut menjalankan fungsi ukurnya atau memberikan hasil ukur yang tepat dan akurat sesuai dengan maksud dikenakannya tes tersebut. Suatu alat ukur yang tinggi validitasnya akan memili error pengukuran yang kecil, artinya skor setiap subjek yang diperoleh alat ukur tersebut tidak jauh berbeda dari skor yang sesungguhnya. Suatu tes dikatakan valid jika tes tersebut mengukur apa yang hendak diukur (Allen dan Yen, 1979).

Validitas tes terdiri dari validitas isi, validitas konstruk, dan validitas berdasarkan kriteria (validitas berdasarkan kriteria terdiri atas validitas prediktif dan validitas konkuren).Validitas isi tes menunjuk sejauh mana seperangkat soal-soal dilihat dari isinya memang mengukur apa yang dimaksudkan untuk diukur. Validitas konstruk mempersoalkan skor-skor hasil pengukuran dengan instrumen itu merefleksikan konstruksi teori tes yang mendasari penyusunan alat ukur tersebut. Validitas kriteria dlihat dari sejauh mana hasil pengukuran dengan alat ukur yang dipersoalkan itu sama atau mirip dengan hasil pengukuran lain yang dijadikan ukuran, dimana kriteria itu dapat dalam waktu sekarang atau waktu yang sesaat dan kriteria diwaktu yang akan datang. Jika kriteria itu sekarang atau dalam waktu dekat dapat dimanfaatkan disebut validitas konkuren, dan jika kriteria itu baru beberapa waktu kemudian dapat dimanfaatkan disebut validitas prediktif. 
Analisis factor adalah prosedur untuk mengidentifikasi item atau variable berdasarkan kemiripannya.Kemiripan tersebut ditunjukkan dengan korelasi yang tinggi. Item-item yang memiliki korelasi yang tinggi akan membentuk satu kerumunan factor (Widiarso, 2009).

Pada analisis factor memungkinkan peneliti untuk 1) menguji ketepatan model (goodness of fit tes) factor yang terbentuk dari item-item alat ukur 2) menguji kesetaraan unit pengukuran antar aitem, 3) menguji reliabilitas item-item pada tiap factor yang diukur, 4) menguji adanya invariant item pada populasi. Jenis Analisis factor (1) Analisis factor eksploratori (exploratory Factor Analisi) Suatu analisis yang digunakan untuk mengetahui atau mengidentifikasi factor yang ada di dalam seperangkat item tersebut. (2) Analisis factor Konfirmatory (confirmatory Factor Analisis.)Analisis factor yang digunakan untuk menguji suatu alat ukur yang telah diketahui dimensinya. Jadi untuk membuktikan bahwa alat ukur tersebut memang terbukti terdiri dari beberapa factor.

\section{METODE}

Definisi operasional kesalehan sosial adalah kesalehan sosial yang menunjukkan pada prilaku individu yang peduli dengan dengan nilai-nilai Islami yang bersifat sosial. Bersikap santun pada orang lain, suka menolong, sangat concern terhadap masalahmasalah ummat, memperhatikan dan menghargai hak sesama; mampu berpikir berdasarkan perspektif orang lain, mampu berempati, artinya mampu merasakan apa yang dirasakan orang lain, dan seterusnya.

Subjek penelitian adalah sumber utama data penelitian, yaitu yang memiliki data mengenai yang diteliti Subjek penelitian yang akan digunakan adalah karyawan perusahaan.Pada penelitian ini patokan jumlah subjek yang digunakan adalah menurut Gable yaitu enam sampai sepuluh kali lipat banyaknya item. Jumlah item skala ini adalah 41 item, jadi subjek penelitian ini adalah antara 240-400 karyawan lebih tepatnya adalah 343 subjek. Penelitian ini dilaksanakan pada perusahaan atau instansi pemerintah yang ada di kota.

Prosedur pelaksanaan penelitian ini melalui tiga tahapan yaitu:

Proses penyusunan skala Kesalehan Sosial

a. Identifikasi tujuan ukur/penetapan konstruk psikologi

Salah satu cara untuk memudahkan identifikasi tujuan ukur adalah dengan menguraikan komponen-komponen atau faktor faktor yang ada dalam konsep teoritik mengenai atribut yang hendak diukur.

b. Operasionalisasi konsep, indikator perilaku (disajikan dalam bentuk blue print), yaitu: (1) dimensi menjelaskan adanya aspek ukur unik yang memiliki domain yang berbeda dengan aspek lainnya. Untuk mengetahui bahwa aspek tersebut merupakan dimensi yang berbeda biasanya dilakukan analisis faktor. Analisis faktor akan menghasilkan faktor-faktor (kadang dinamakan dimensi); (2) aspek adalah penjabaran konstrak ukur yang lebih operasinal sebelum dijabarkan lagi menjadi indikator indikator perilaku yang lebih operasional. Aspek-aspek inilah yang pada akhirnya djabarkan menjadi indikator dan item dalam skala; (3) aspek merupakan domain-domain ukur teoritik 
yang belum diuji apakah masing-masing memiliki independensi ataukah tidak. Jika masing-masing domain teoritik tersebut memiliki independensi yang dibuktikan dengan analisis faktor maka dinamakan dengan dimensi atau faktor. (4) Indikator perilaku adalah bentuk-bentuk perilaku yang mengindikasikan ada tidaknya suatu atribut psikologis. (5) Blue Print skala psikologi disajikan dalam bentuk tabel, yang memuat uraian komponen-komponen atribut yang harus dibuat itemnya, proposi item dalam masing masing komponen, serta indikator perilaku dalam setiap komponen. Blue print akan memberikan gambaran mengenai isi skala dan menjadi pedoman bagi penulis untuk tetap berada dalam lingkup pengukuran yang benar.

c. Penskalaan dan pemilihan format stimulus

Penskalaan digunakan untuk menentukan skor pada masing-masing item setelah diuji cobakan. Model penskalaan ini yang digunakan dalam penyusunan skala perkembangan moral ini adalah pendekatan respon (skala likert).

d. Penulisan Item (review item)

e. Analisis Item

Analisis item dalam skala psikologi meliputi seleksi item (korelasi item-total) menggunakan formula koefisien korelasi product moment, dan dilanutkan dengan melakukan koreksi terhadap efek suporious overlap.

f. Kompilasi I (seleksi item)

Item yang dinyatakan valid adalah apabila korelasi antara item-total > dari 0,30. Validitas item juga dapat ditentukan berdasarkan $\mathrm{r}$ tabel.

d. Pengujian Reliabilitas

Pengujian reliabilitas dilakukan pada sejumlah item yang telah dinyakan valid.

e. Validasi

Validasi dilakukan dengan menyusun ulang nomer item jadi sesuai dengan blue print serta banyakya item pada masing-masing aspek yang diukur.

f. Kompilasi II (format final)

Skala siap untuk di gunakan.

Tahap Pelaksanaan Penelitian

Uji coba tes dilaksanakan mungkin cukup sekali atau lebih sampai mendapatkan butir soal yang memenuhi kriteria. Suryabrata (2000) menyatakan jika satu kali uji coba sudah mendapatkan tes yang memadai maka uji coba cukup dilakukan satu kali. Penelitian dilakukan dengan memberikan alat ukur kepada subjek penelitian untuk diisi secara lengkap.

\section{HASIL}


Berdasarkan hasil analisis data pada alat ukur kesalehan sosial dengan menggunakan korelasi item - total dengan Product Moment terdapat 27 item yang diterima dan 14 item yang tidak diterima.

Tabel 1. Item Yang Valid

\begin{tabular}{|c|c|c|}
\hline No & Aspek & Item \\
\hline 1 & Solidaritas & $2,6,32,12$ \\
\hline 2 & Kerja Sama & $1,13,22,20,27$ \\
\hline 3 & Toleransi & $3,40,18$ \\
\hline 4 & Adil dan seimbang & $5,15,24,8,17$ \\
\hline 5 & Mempertimbangkan kesejahteraan umum & $9,16,36$ \\
\hline 6 & Menolong & $33,4,39,35$ \\
\hline 7 & Kejujuran & $34,23,31$ \\
\hline
\end{tabular}

Seleksi item ditentukan dengan menggunakan $r$ tabel sebesar 0,09 dengan df 342. Alasan menggunakan $r$ tabel adalah banyak terdapat item yang korelasi item dengan totalnya kurang dari 0,30 sehingga tidak menggunakan patokan korelasi item - total > 0,30. Dari patokan $\mathrm{r}$ tabel mengakibatkan reliabilitasnya rendah sehingga peneliti memutuskan dengan menggunakan $r=0,150$ dimana dengan patokan ini dapat mengukur seluruh kawasan domain ukur dan reliabilitasnya terpenuhi. Reliabilitas alat ukur sebesar 0, 797. Dari tujuh aspek semua itemnya terwakili sehingga alat ukur ini bisa digunakan dan telah memenuhi seluruh kawasan domain ukur.

Tabel 2: Item Alat Ukur Kesalehan Sosial

\begin{tabular}{cl}
\hline No & \multicolumn{1}{c}{ Solidaritas Sosial } \\
\hline 2 & Berpartisipasi dalam kegiatan sosial dilingkungan kerja \\
6 & Peduli dengan rekan kerja yang sakit atau kesusahan \\
32 & Menyisihkan sebagian gaji untuk orang-orang yang kurang mampu \\
12 & Menghindari kegiatan sosial yang melibatkan seluruh karyawan \\
\hline No & \multicolumn{1}{c}{ Kerja Sama } \\
\hline 1 & Saya akan bekerja sama dengan divisi lain untuk meningkatkan kinerja \\
13 & Menyelesaikan tugas sesuai dengan prosedure \\
22 & Menyelesaikan tugas sesuai dengan batas waktu yang telah ditentukan \\
20 & Saya kurang memperhatikan benar atau salah dari tugas yang sudah terselesaikan \\
27 & Saya hanya diam dan mendengarkan saja ketika rapat sedang berlangsung \\
\hline No & \multicolumn{1}{c}{ Toleransi } \\
\hline 3 & Menghargai rekan kerja yang berbeda keyakinan \\
40 & Menghargai rekan kerja yang mengambil cuti untuk kegiatan yang berbeda \\
& dengan saya \\
38 & Menarik diri ketika melihat adanya perbedaan agama dan budaya dengan rekan \\
\hline No & kerja \\
\hline 5 & Memilih menjadi penengah jika ada perselisihan di tempat kerja
\end{tabular}




\begin{tabular}{cl}
15 & Memberikan kesempatan kepada orang lain untuk menyampaikan pendapatnya \\
24 & Menerima rekan kerja dengan kemampuan yang berbeda -beda \\
8 & Saya bekerja dengan memprioritaskan kenaikan pangkat bagi yang satu visi \\
17 & Saya bahagia ketika mendapatkan gaji yang lebih tinggi dari rekan kerja \\
\hline No & \multicolumn{1}{c}{ Mempertimbangkan kesejahteraan umum } \\
\hline 9 & Terlibat dalam upaya perbaikan kinerja \\
16 & Memilih diam jika ada yang menyalahi aturan dalam bekerja \\
36 & Menjaga ketertiban dan kebersihan di lingkungan kerja \\
\hline No & \multicolumn{1}{c}{ Menolong } \\
\hline 33 & Saya akan membantu tugas rekan kerja ketika sudah menyelesaikan tugas pribadi \\
4 & Meskipun berilmu, berhata serta memiliki kedudukan yang tinggi, Saya akan \\
& menolong siapapun \\
39 & Saya bersedia menggantikan tugas rekan kerja yang mengalami musibah \\
35 & Membantu rekan kerja yang mengalami kesulitan \\
\hline No & \multicolumn{1}{c}{ Kejujuran } \\
\hline 34 & Saya menghindari untuk memanfaatkan fasilitas di tempat kerja untuk \\
& kepentingan pribadi \\
23 & Menjaga amanah yang dipercayakan kepada saya dengan sebaik baiknya \\
31 & Saya selalu memanipulasi hasil kerja
\end{tabular}

Kesalehan sosial pada karyawan bisa dikategorikan melalui skor T, hasil selengkapnya dapat dilihat pada tabel berikut:

Tabel 3: $\mathbf{T}$ score

\begin{tabular}{|c|c|c|c|c|}
\hline No & Kategori & Skor T & Jumlah & prosentase \\
\hline 1 & Tinggi & $>50$ & 174 karyawan & $49,28 \%$ \\
\hline 2 & Rendah & $\leq 50$ & 169 Karyawan & $50,72 \%$ \\
\hline
\end{tabular}

\section{DISKUSI}

Analisis data penelitian ini menggunakan korelasi item dengan total dan terdapat 27 item yang valid. Analisis selanjutnya adalah analisis faktor yaitu confirmatory faktor analisis. Confirmatory faktor analisis ini untuk menguji apakah item item tersebut sudah sesuai dengan faktornya atau tumpang tindih dengan aspek aspek yang lainnya. Dalam confirmatory faktor analisis terdapat asumsi asumsi yang harus dipenuhi yaitu goodness of Fit. Ada tiga formula untuk menentukan goodnes of fit dan tergantung peneliti menggunakan model yang dipilih. Dalam penelitian ini peneliti menggunakan RMSEA, CFI dan GFI. RMSEA < 0,8 CFI dan GFI > 0,90. Uji goodnes of fit tidak memenuhi GFI CFI dan RMSEA tidak memenuhi sehingga item yang memiliki faktor loading < dari 0,50 dihapus $(3,5,16,17,21,27,30,34,38)$. Hasil goodness of fit tetap belum memenuhi sehingga mengkovariankan Langkah selanjutnya adalah mengkovariankan antar error sesuai dengan saran modifikasi index karena masih belum fit maka dilakukan pengurangan pada item yang masih memiliki faktor loadimg, dari 0,50 yaitu (item 20 
dan 21) serta konstain 1 pada masing masing faktor. Tetapi blm memenuhi goones of fit bahkan hasilnya error karena dalam satu faktor hanya ada satu item yang faktor loadingnya diatas 0,50 sehingga alat ukur ini tidak dapat dianalisis menggunakan confirmatory factor analisis. Sejalan dengan penelitian yang dilakukan oleh (Bufford et al., 2015) yang meneliti tentang Dimensi Rahmad yang mengulas tentang analisis faktor dimensi Rahmad yang terdiri dari tiga faktor. Dalam analisis tersebut tidak dapat dilakukan confirmatory factor analisis karena dimensi Rahmat merupakan dimensi religiusitas yang di gabung dengan Konstruk Psikologis. Pada dimensi tersebut hanya menggunakan exploratory factor analisis dan hasilnya terdapat 5 faktor yang membentuk dimensi tersebut. Dimensi berbeda konstruk dan merupakan dimensi yang multidimensional.

Validitas konstruk alat ukur ini dianggap kurang baik karena dasar teori konstruk ini kurang mantap dan masih mengacu pada prososial dan tidak berdiri sendiri. Definisi secara operasional dari kesalehan sosial ini bukan merupakan konstruk psikologis tetapi aspek-aspek dari definisi konsep kesalehan sosial dan prososial mendekati kesamaan sehingga bisa dipadukan. Penelitian yang dilakukan oleh (Part \& Sciences, 2014) menyatakan bahwa konsep keagamaan dapat diukur dan masuk dalam kajian psikologi agama maupun psikoreligiusitas. Konsep keagamaan yang aspek-aspeknya memiliki kesamaan dengan konstruk psikologis dapat dipadukan sebagai penelaahan konsep agama dalam kajian scientis.

Hasil pengujian skor T menunjukkan bahwa sebanyak 49,27\% termasuk dalam kategori rendah dan sebanyak 50, $72 \%$ termasuk kategori tinggi. Antara yang memiliki kesalehan sosial yang tinggi dengan rendah seimbang. Hal ini bisa dipengaruhi oleh budaya. Budaya indonesia tertanam untuk saling membantu sesama tanpa pamrih kepada sesama. Seuai dengan penelitian (Part \& Sciences, 2014) yang menyatakan bahwa konsep keagamaan yang memiliki aspek kesamaan dengan konstruk psikologi juga dipengaruhi oleh budaya.

\section{SIMPULAN DAN IMPLIKASI}

Berdasarkan hasil analisis data pada alat ukur kesalehan sosial dengan menggunakan korelasi item - total dengan Product Moment terdapat 27 item yang diterima dan 14 item yang tidak diterima. Reliabilitas $\mathrm{rxx}=0.797$

Penelitian ini merupakan penelitian awal sehingga perlu diadakan revisi khususnya dasar teori mengenai konstruk yang hendak diukur. Saran yang dapat diberikan adalah alat ukur ini dapat digunakan sebagai alat ukur yang mengungkap tentang kesalehan sosial individu karena seluruh item telah memenuhi seluruh kawasan domain ukur. Bagi peneliti selanjutnya diharapkan untuk merevisi item item yang dianggap memiliki korelasi item yang rendah sehingga dapat dijadikan sebagai alat ukur yang akurat. Selain itu, aspek aspek dalam alat ukur kesalehan sosial yang dianggap saling tumpang tindih maka bisa direduksi. 


\section{REFERENSI}

Aghababaei, N. (2014). God, the good life, and HEXACO: The relations among religion, subjective well-being and personality. Mental Health, Religion and Culture, 17(3), 284-290. https://doi.org/10.1080/13674676.2013.797956

Bufford, R. K., Blackburn, A. M., Sisemore, T. A., Bassett, R. L., Bufford, Rodger K.Blackburn, Amanda M.Sisemore, Timothy A.Bassett, R. L., Bufford, R. K., ... Bassett, R. L. (2015). Preliminary Analyses of Three Measures of Grace: Can They be Unified? Journal of Psychology \& Theology, 43(2), 86-97. Retrieved from http://web.b.ebscohost.com/ehost/detail/detail?vid=20\&sid=fc90ac82-cf72-4220bad3-

5ac939f19e81@sessionmgr112\&hid=102\&bdata=JnNpdGU9ZWhvc3QtbGl2ZSZz Y29wZT1zaXRl\#AN=2015-27097-

002\&db=psyh\%5Cnhttp://digitalcommons.georgefox.edu/cgi/viewcontent.cgi?articl $\mathrm{e}=1107 \&$

Miyatake, S., \& Higuchi, M. (2017). Does religious priming increase the prosocial behaviour of a Japanese sample in an anonymous economic game? Asian Journal of Social Psychology, 20(1), 54-59. https://doi.org/10.1111/ajsp.12164

Moltafet, G., Mazidi, M., \& Sadati, S. (2010). Personality traits, religious orientation and happiness. Procedia - Social and Behavioral Sciences, 9, 63-69. https://doi.org/10.1016/j.sbspro.2010.12.116

Part, B., \& Sciences, S. (2014). Econstor, 9(3), 276-284. https://doi.org/10.1037/rel0000136

Riadi H. 2014. Kesalehan sosial sebagai parameter kesalehan keberislaman ( ikhtiar baru dalam menggagas mempraktekan taukhid sosial) An nida: jurnal pemikiran islam, vol 39: no 1 januari-juli

Sears, David O.Fredman, Jonathan L., \&Peplau, L.A .1994.Psikologi sosial jilid 2. Alih Bahasa: Michael Adryanto. Jakarta. Erlangga

Suryabrata,S (2000). Penyusunan Alat Ukur Psikologi. Yogyakarta Pustaka Pelajar

Zuhri S. 2014. Pendidikan Transformasi Kesalehan Sosial Individu Menuju Kesalehan Sosial Diera Globalisasi.Naskah Publikasi.Progam Studi Magister Pendidikan Islam. Sekolah Pasca Sarjana Uinversitas Muhammadiyah Surakarta. Tidak Dipublikasikan.

Widiarso, W. 2009. Modul Statistik. Fak Psikologi UGM. Tidak Diterbitkan

Artikel Dosen Comments Off on Kesalehan Individual dan Kesalehan Sosial (Dr. Hj. Helmiati, M.Ag) 19th August 2015. Diunduh 3 Januari 2018

KH A. Mustofa Bisri*http://kesalehansosial.blogspot.co.id. diunduh tgl 3 januari 2018 http://sodikinmuhammad.blogspot.co.id/2011/12/hubungan-ibadah-dan-kesalehansosial_04.htm. Diunduh 3 januari 2018s 